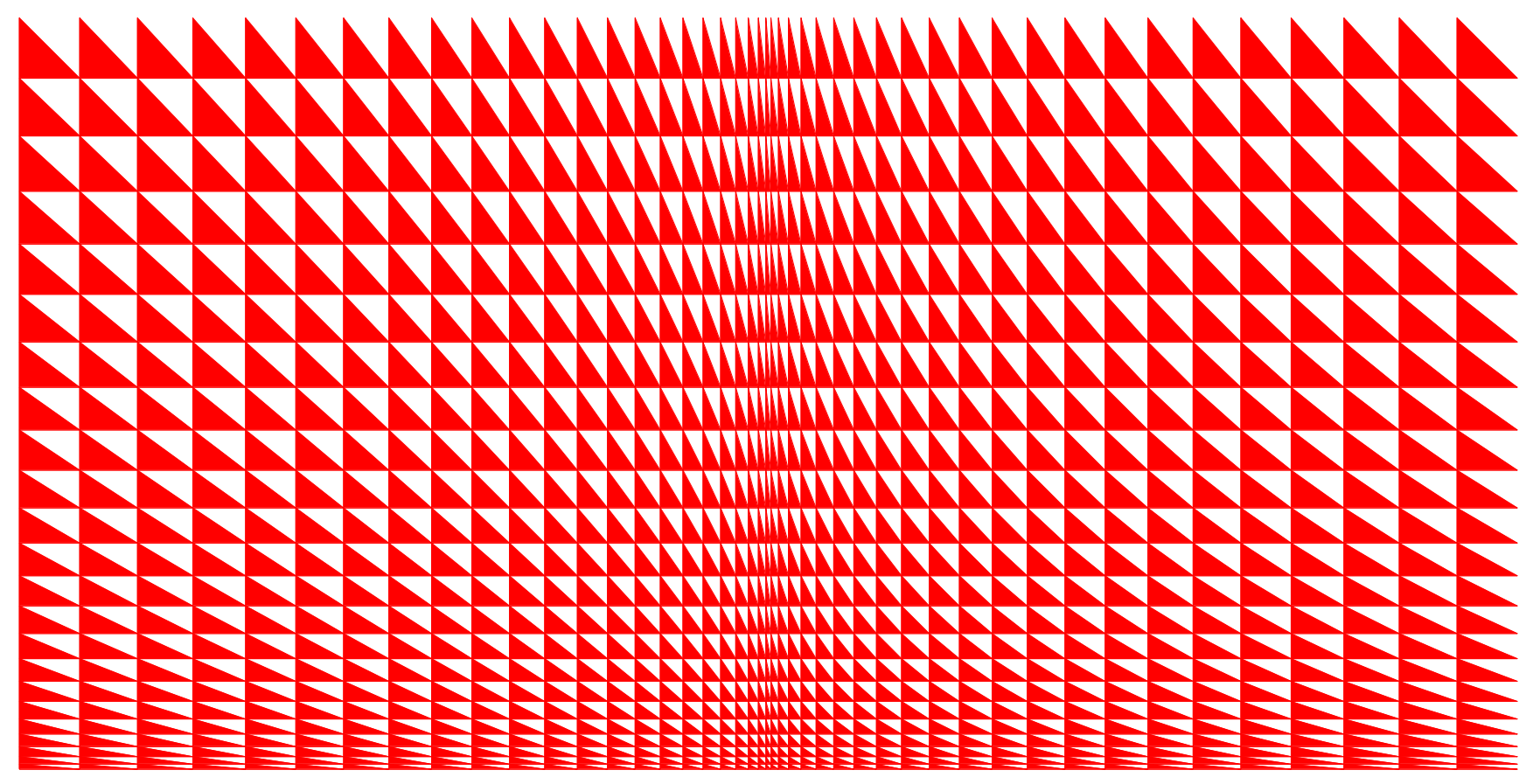

\title{
INTERVENÇÕES CONTEMPORÂNEAS EM \\ ESPAÇOS UNIVERSITÁRIOS
}

MÔNICA M. GRANER

FAUUSP 2017 
CAPA - Obra 26, de Luiz Sacilotto (1924-2003), artista natural de Santo André, instalada na Universidade Federal do $A B C$, Campus Santo André, Bloco B, em colagens de 1.035 triângulos em MDF, formando um painel com dimensões de 16 metros de comprimento por 8 metros de altura. A obra é a interpretação de uma progressão aritmética de razão 3. Foi selecionada por representar a relação entre arte e ciência.

Fonte: Família Sacilotto,2005. 


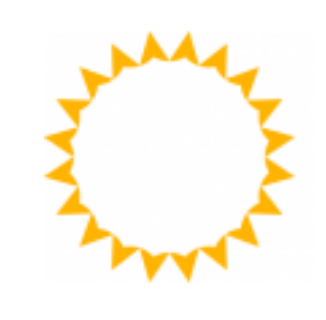

\title{
MÔNICA MASCARENHAS GRANER
}

\section{INTERVENÇÕES CONTEMPORÂNEAS EM ESPAÇOS UNIVERSITÁRIOS}

\author{
DISSERTAÇÃO APRESENTADA À \\ FACULDADE DE ARQUITETURA E URBANISMO DA \\ UNIVERSIDADE DE SÃO PAULO PARA OBTENÇÃO DO TÍTULO \\ MESTRE EM ARQUITETURA E URBANISMO
}

ÁREA DE CONCENTRAÇÃO:

PROJETO DE ARQUITETURA

ORIENTADORA:

Dra. HELENA APARECIDA AYOUB SILVA

EXEMPLAR REVISADO E ALTERADO EM RELAÇÃO À VERSÃO ORIGINAL, SOB RESPONSABILIDADE DO AUTOR E ANUÊNCIA DO ORIENTADOR

SÃO PAULO 
AUTORIZO A REPRODUÇÃO E DIVULGAÇÃO TOTAL OU PARCIAL DESTE TRABALHO, POR QUALQUER MEIO CONVENCIONAL OU ELETRÔNICO, PARA FINS DE ESTUDO E PESQUISA, DESDE QUE CITADA A FONTE.

e-mail: mom.graner@gmail.com

Graner, Mônica Mascarenhas

G756i Intervenções contemporâneas em espaços universitários / Mônica Mascarenhas Graner. -- São Paulo, 2017.

120 p. : il. + anexo

Dissertação (Mestrado - Área de Concentração: Projeto de Arquitetura) - FAUUSP.

Orientadora: Helena Aparecida Ayoub Silva

1.Universidades (Arquitetura) 2.Cidades Universitárias 3.Projeto de Arquitetura 4.Universidade Federal do ABC I.Título

CDU 727.3 
PARA MEUS PAIS

JOSÉ MARIA E ANNA 


\section{AGRADECIMENTOS}

À professora Helena Ayoub pela orientação, disposição e incentivo durante todo o processo da pesquisa.

Aos professores Carlos Roberto Monteiro de Andrade, Paulo Bruna e Luiz Bevilacqua pelas contribuições e incentivo.

À querida Ana Maria de Oliveira pelas reflexões, apoio inestimável e apurada revisão do texto.

À equipe do DDPU de Santo André - Margarida Sakata, Reinaldo Bascchera, Valéria Delaguardia, Belmiro Rodrigues, à historiadora Suzana Kleeb e ao Museu de Santo André Dr. Octaviano Armando Gaiarsa pelas contribuições.

À Fondazione Ca'Romanino - Laura Piccioni, Stefania Galli, Tiziana Fuligna e especialmente A querida Sonia Morra pelas contribuições e incentivo.

Aos escritórios Benno Perelmutter Arquitetura e Planejamento (em especial ao Marciel Peinado), LibeskindLlovet Arquitetos, Tao Arquitetura, Andrade e Morettin Arquitetos, Dal Pian Arquitetos e ao Walter Sacilotto.

À equipe de funcionários da FAU, em especial Maria José, Cleide e Isa.

Aos meus amigos da FAU Jonathas Magalhães, Ralf Korbmacher e Wilson Jorge Filho pelas sugestões, contribuições e incentivo.

Aos meus amigos Eduardo Babadopulos, Carla Oliveira, José Carlos Costa, Manuel Barral pelo incentivo e apoio.

A Anna, Marília, Gustavo e Xexéu, minha adorada família.

A Beatriz e Carolina, meus amores, meu oásis. 


\section{RESUMO/ABSTRACT}

GRANER, Mônica M. Intervenções contemporâneas em espaços universitários. 2017. 121f. Dissertação (Mestrado). Faculdade de Arquitetura e Urbanismo da Universidade de São Paulo, São Paulo, 2017.

A Universidade é um centro de produção de conhecimento e reflete os contextos social, cultural, histórico e econômico que compõem a complexa tessitura de decisões políticas e embates entre interesses públicos, privados e a sociedade. Torna-se o motor da transformação urbana, porque requalifica o tecido urbano em que está estrategicamente inserida. Seu projeto urbanístico arquitetônico tem a responsabilidade de traduzir as forças, conflitos, desafios e sintetizá-los como contribuição ao espaço construído. A exemplo disto, esta dissertação trata do processo de implantação da Universidade Federal do ABC - UFABC, iniciada a partir de 2004, na região do Grande $A B C$ paulista, concebida com uma missão ideológica bastante definida de tornar-se um equipamento urbano estratégico para as cidades do ABC.

Trata-se de uma experiência de política pública que objetivou, em âmbito federal, a democratização, a expansão e a melhoria da qualidade do ensino superior por meio da implantação de um novo projeto pedagógico, voltado para o século XXI e, em âmbito regional e municipal, representou um marco arquitetônico e urbanístico que se propôs a promover a inclusão social, a requalificação e a intensificação da vida e do espaço urbanos.

É certo que a UFABC se caracteriza como uma intervenção bastante renovadora para modelos de campi universitários, porém a realidade revela que muitas possibilidades são convertidas em ideologias irrealizadas e nem sempre a relação entre universidade e cidade é simbiótica. Ao revisitar seu processo de implantação e contextualizá-lo, esta pesquisa propõe-se a uma interpretação crítica das ações realizadas, visando a algumas contribuições para ampliar o tema abordado: espaços universitários contemporâneos.

PALAVRAS-CHAVE: Projeto de Arquitetura. Universidades. Campus Universitário. UFABC.
GRANER, Mônica M. Contemporary interventions in university spaces. 2017. 121f. Dissertação (Mestrado). Faculdade de Arquitetura e Urbanismo da Universidade de São Paulo, São Paulo, 2017.

As a center for the production of knowledge, the University mirrors the social, cultural, historical and economic contexts that characterize the complex web of political choices and conflicts among public and private entities, and society at large. The university is the engine of urban transformation because it re-qualifies the urban fabric in which it is strategically located. Its urbanistic and architectural project ought to synthesize the dynamics of power, conflict, and challenges into the built environment. This dissertation is a case study for this process, examining the creation of Universidade Federal do $A B C$ (Federal University of the $A B C$ region) UFABC - in 2004. UFABC was conceived with the well-defined ideological mission of becoming a strategic urban equipment for the cities that comprise the grande $A B C$ (designation for the conurbated cities of Santo André, São Bernardo, and São Caetano, which are adjecent to the metropolitan area of São Paulo).

This experiment in federal public policy was aimed at democratizing, expanding, and improving the quality of higher education through a new pedagogical project specifically designed for the 21st Century. At the regional and municipal levels it is an architectural and urbanistic milestone that aims to promote social inclusion and re-qualify and intensify urban space and life.

While UFABC strove to renew the prevailing university campus models, the end result is that many possibilities remain unfulfilled ideological projects, and the relationship between the university and the city is not always symbiotic. By reviewing the implementation process and its context, this research provides a critique through the lens of theoretical frameworks concerned with contemporary architecture and urbanism.

KEYWORDS: Architectural Project. Universities. University Campus. UFABC. 
INTRODUÇÃO___ 8

1. ANTECEDENTES DA UNIVERSIDADE A PARTIR DE $1960 \_14$

1.1. A busca da integração universitária _ـ 14

1.2. O Processo de Bologna ___ 23

1.3. A Universidade de Brasília___ 27

1.4. A Expansão do Sistema Federal de Educação Superior 2003-2014____ 31

2. A CRIAÇÃO DA UFABC E SUA IMPLANTAÇÃO _ 40

2.1. O Projeto Eixo Tamanduatehy___ 40

2.2. A Implantação da UFABC: Campus Santo André ___ 51

2.3. Área para a implantação da Universidade___ 52

2.4. A Lei de Criação da UFABC _ـ 53

2.5. O Projeto Pedagógico ___ 55

2.6. O Concurso Nacional para Projetos Arquitetônicos __ 57

2.7. Entrevista com Sandra Llovet e Claudio Libeskind ___ 82

2.8. A expansão multicampi: o campus São Bernardo ___ 86

3. CONSIDERAÇÕES FINAIS _ 105

3.1. Campus Santo André - $2005 \_106$

3.2. Campus São Bernardo - $2008 \_109$

3.3. Conclusão _ـ 111

ÍNDICE DE IMAGENS _ـ 113

REFERÊNCIAS _ 116

ANEXOS 121 


\section{INTRODUÇÃO}

No início do novo milênio, as Universidades são agentes com significativas influências nas cidades, regiões e nações. Impactam o emprego, o ambiente construído, a ciência, a tecnologia e a sociedade em geral. Sua estreita relação com a cidade remonta à sua fundação, na Idade Média. Para C. Charle e J. Verger (1996) a Universidade é um segmento decisivo da história da cultura ocidental e, ao compreender sua história, compreende-se uma parte de herança intelectual e do funcionamento de nossas sociedades.

Mais de dez mil universidades estão distribuídas pelo mundo, dedicadas ao ensino superior e atendendo mais de duzentos milhões de estudantes ${ }^{1}$. Grande montante de recursos tem sido aplicado em educação superior, na pesquisa científica para o desenvolvimento tecnológico, o que se reflete nos espaços universitários.

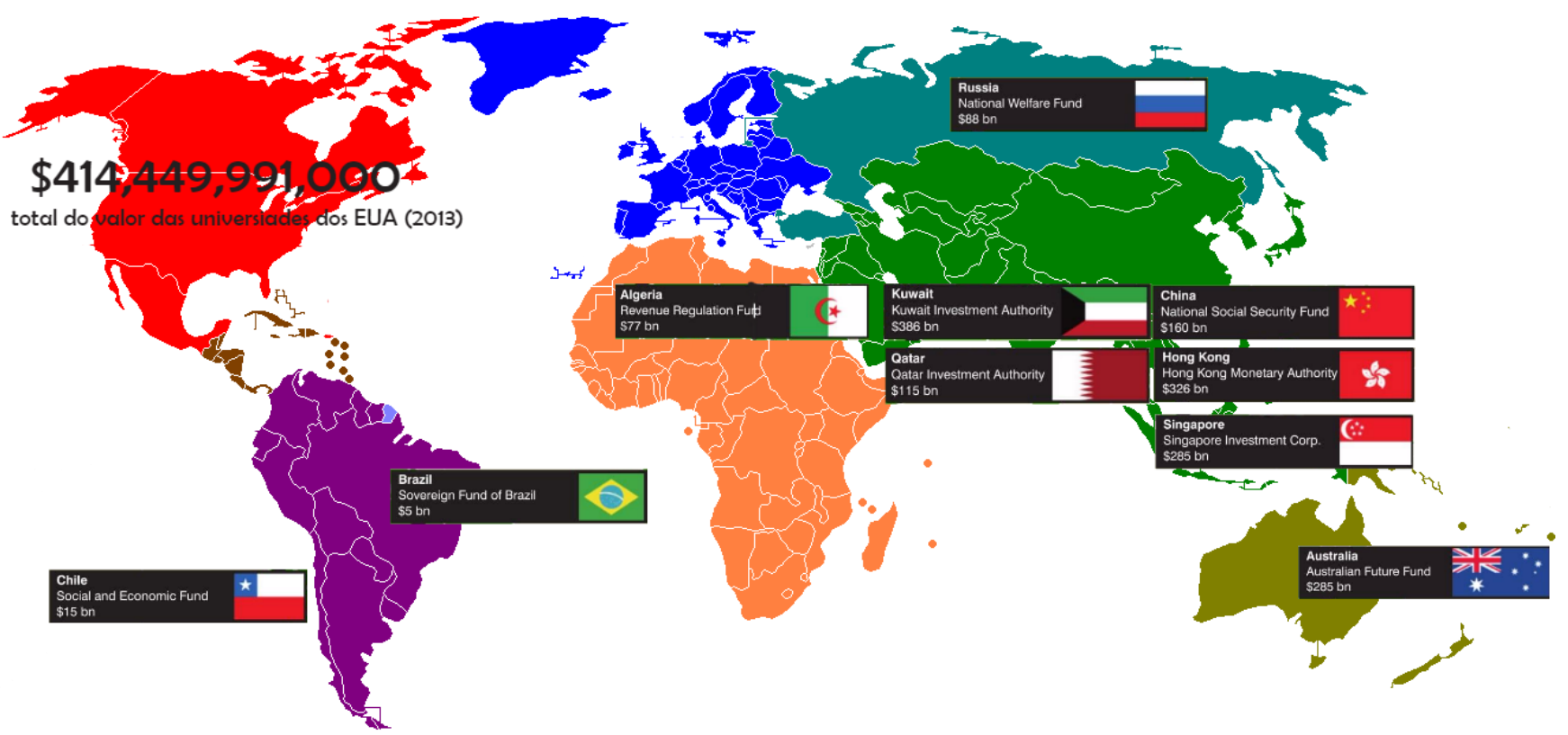

IMAGEM 1 A riqueza acumulada das universidades americanas ultrapassa o Fundo de Riqueza Soberana de diversos países. Fonte: (DENNY, 2016)

1 Dados da Conferência da OCDE 2010 - Organização para Cooperação e Desenvolvimento Econômico - fórum que reúne governos de 35 países democráticos, trabalhando conjuntamente para enfrentar os desafios econômicos, sociais e ambientais da globalização. Disponível em www.oecd.org. Acesso em 27 setembro 2016 
Cidades com forte presença universitária têm um desempenho socioeconômico diferenciado e um valor agregado à sua autoimagem por tratar-se a universidade nela inserida de um projeto coletivo que atende às exigências econômicas e elevam índices de justiça social e democracia. Foi esse o caráter ideológico que conformou a implantação da Universidade Federal do ABC, hoje com dois campi consolidados nos municípios de Santo André e São Bernardo do Campo, representando um equipamento urbano estratégico, desenvolvido para a retomada da dinamização econômica, urbana e social da região do ABC Paulista.

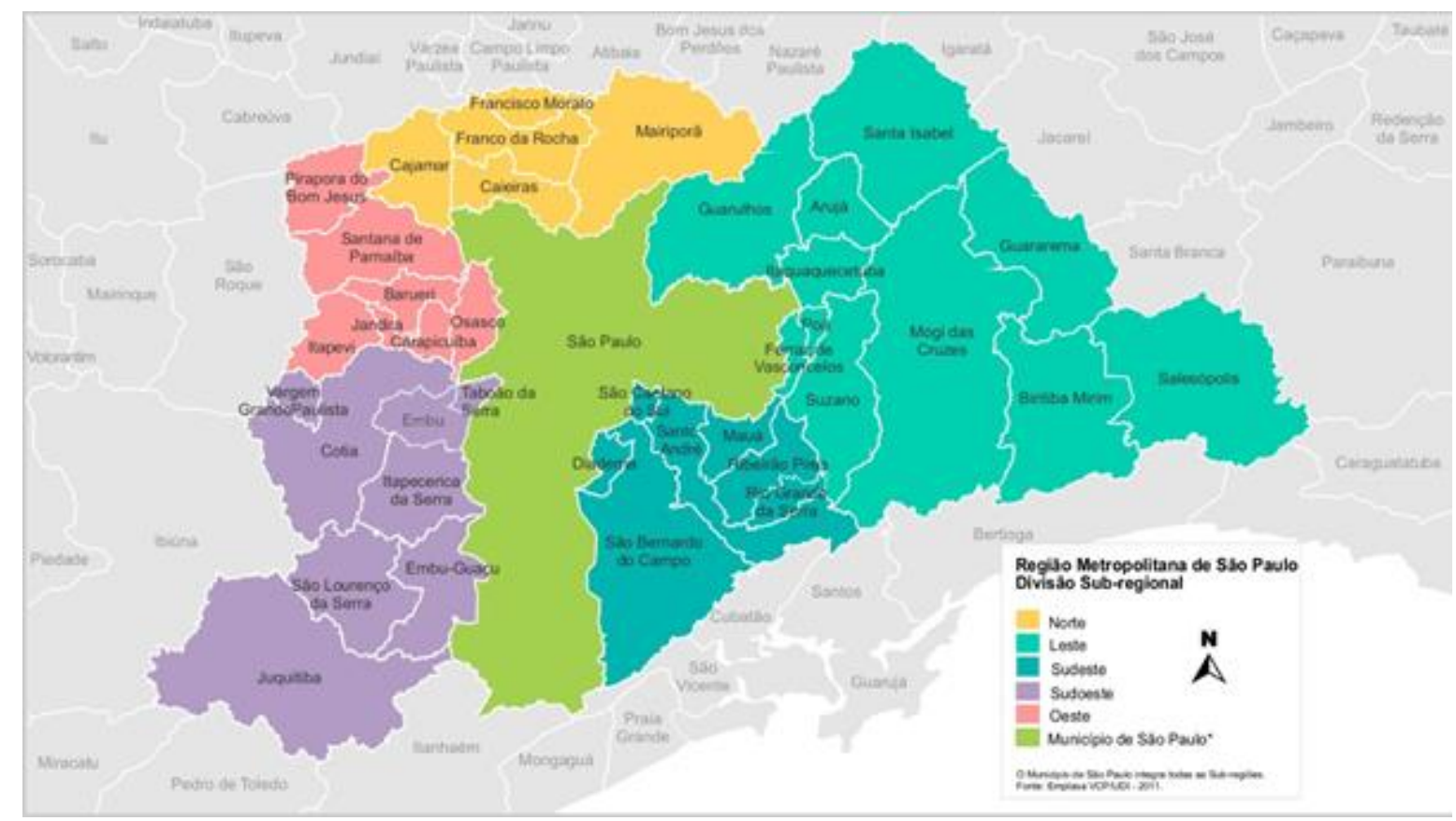

IMAGEM 2 ABC PAULISTA (Sudeste) - inserido na RMSP. Fonte: EMPLASA VCP/UDI 2011

Reconstituir o processo de implantação da UFABC, contextualizá-lo e analisá-lo criticamente demanda o enfrentamento de uma pluralidade de interpretações no campo da arquitetura e urbanismo. Universidades, espaços universitários, campi, cidades universitárias têm sido objeto de pesquisas acadêmicas e publicações organizadas desde o final do século XIX, por tratar-se de categorias muito particulares de ocupação do território.

Ao experimentar novas interpretações, Josep Maria Montaner propõe a teoria dos sistemas como um método admissível para entender a arquitetura contemporânea. Emprestando o termo do campo da biologia - e o estendendo a outras disciplinas -, defende que a teoria dos sistemas pode ser uma referência para explicar a arquitetura e o urbanismo, a partir da sociedade e da política, dos interesses das classes sociais e, ao mesmo tempo, examinar a complexidade formal e estrutural de seus espaços construídos: 
O que significa aplicar a teoria dos sistemas à arquitetura contemporânea? [...]. É analisar as capacidades de cada sistema de estruturar-se e, ao mesmo tempo, interagir com seu contexto. [...] entendo que um sistema é um conjunto de elementos heterogêneos (materiais ou não), em distintas escalas, relacionadas entre si, com uma organização interna que tenta estrategicamente adaptar-se à complexidade do contexto, constituindo um todo que não é explicável pela soma das suas partes. Cada parte do sistema está em função de outra; não há elementos isolados. Dentro dos diversos sistemas, que se podem estabelecer, a arquitetura e o urbanismo são sistemas do tipo funcional, espacial, construtivo, formal e simbólico. (MONTANER, 2009, p. 11)

Há uma evidente proximidade entre a conceituação de Montaner e a proposta conceitual da UFABC, conforme texto produzido pela equipe de cientistas que concebeu o projeto pedagógico da universidade, sobretudo por destacar o conceito de sistema ou rede, segundo o qual o produto não é a soma das partes, e sim a relação entre as partes, conceito este que será usado ao longo desta pesquisa:

A impossibilidade do conhecimento enciclopédico (ou seja, do conhecimento de "tudo sobre tudo") já é reconhecida pelo menos desde o século XVIII. Diante dela, a apropriação do conhecimento passou a ser feita por partes (ou por espécie), num movimento que ficou conhecido como especialização. Nele, a busca do saber é focada sobre certa espécie de fenômeno ou técnica, geralmente caracterizada pela sua natureza (p.ex. elétrica, mecânica, química, etc.). Na medida em que esta tendência foi se aprofundando, as especialidades foram se estreitando, abrangendo aspectos cada vez mais limitados da realidade. Durante a segunda metade do século $X X$, surgiram os primeiros indícios de insuficiência deste modo de apropriação do conhecimento no trato de questões complexas, que atravessam diversas especialidades sem ser capturada por nenhuma.

O próprio século $X X$, ao perceber essas dificuldades, gerou alguns novos conceitos que pretendem lidar com esta situação. O primeiro deles é a noção de sistema, que em poucas décadas se incorporou à visão do homem moderno. Ela permite abstrair a natureza física dos fenômenos, colocando-os num universo novo, abstrato, onde só interessa a relação entre as grandezas em jogo. A natureza sistêmica está na relação entre as coisas, e não nelas em si. Através do seu estudo, é possível compreender ao mesmo tempo diversas instâncias de uma mesma fenomenologia, ainda que sua manifestação se dê em contextos físicos bastante distintos.

Na segunda metade do século XX, a necessidade de resgatar a integridade do conhecimento levou a uma nova abordagem, que consiste na articulação de várias disciplinas para atacar determinado problema ou problemática, caso a caso: é a chamada interdisciplinaridade[...].

O problema da apropriação do conhecimento, no âmbito da sociedade mais justa e humana desejada para o século XXI, ainda não está resolvido. Porém, acreditamos que a visão sistêmica e a abordagem interdisciplinar apontam na direção correta. Por isso, a Universidade Federal do ABC será dotada de uma estrutura maleável e aberta, sem Departamentos, permeável aos novos modos e ritmos de apropriação do conhecimento. (UFABC, 2006) 
Edgar Morin, ao analisar a sociedade contemporânea, tem as mesmas inquietações quanto à educação pela especialização:

...o ensino por disciplina, fragmentado e dividido, impede a capacidade natural que o espírito tem de contextualizar, é essa capacidade que deve ser estimulada e deve ser desenvolvida pelo ensino de ligar as partes ao todo e o todo às partes. (MORIN, 2001, p. 4)

Ou seja, há um empenho contemporâneo em valorizar as articulações entre as partes, sobretudo para entender conjuntos mais complexos, como uma universidade, por exemplo.

Assim, para uma melhor compreensão da UFABC como um sistema, este trabalho a situará em contexto global, federal, regional e municipal, considerando os aspectos históricos e a avaliação do cumprimento de suas finalidades como campus universitário: relação com o contexto urbano, o lugar e o meio ambiente, funcionalidade e expressão de símbolos e significados.

A escolha por espaços universitários como tema do trabalho tem vínculo com a minha proximidade profissional ao projeto de implantação da UFABC. Fui a arquiteta da equipe prótempore em 2006, Prefeita Universitária no período de outubro de 2006 a março de 2008 e, por fim, fui convidada pelo reitor Luiz Bevilacqua para coordenar a implantação do Campus São Bernardo no período de abril de 2008 a novembro de 2011. Atuei imersa em atividades de gestão técnica e administrativa dimensionadas pelos propósitos institucionais. A perspectiva do meu olhar nessa época foi marcada pela honra de participar de um projeto social dessa envergadura, na urgência em erigir uma universidade a partir de uma tela branca, pautando pela qualidade e responsabilidade técnica, ética e social como convém a um arquiteto nascido no ABC Paulista e graduado em uma universidade pública. Do lugar de gestora, passei ao de pesquisadora a partir da escolha desta experiência como tema. Daí a expressão "revisitar" o processo de implantação da UFABC e sua proposta educacional renovadora à luz de fundamentações teóricas que possibilitem uma interpretação crítica de aspectos afetos à arquitetura e urbanismo contemporâneos.

Em agosto de 2016, em razão da minha pesquisa, fui contemplada com uma bolsaauxílio pelo Ministério da Educação e Pesquisa do governo alemão, o que permitiu visitar algumas universidades europeias, contribuindo para esta dissertação.

Para constituir este trabalho, o texto foi dividido em 3 capítulos. O capítulo 1 remete aos movimentos estudantis europeus dos anos 1960 e a participação dos arquitetos que 
fizeram das universidades seus laboratórios para novas propostas arquitetônicas e urbanísticas, em especial grupo Team X. Antes de analisar a universidade brasileira no mesmo período, o texto dá continuidade cronológica e passa a abordar a globalização e seus efeitos no ensino superior, sobretudo na Europa que, para enfrentar os desafios impostos pela nova ordem mundial e resgatar sua posição de hegemonia, com a criação da União Europeia em 1993, foi compelida a unificar seu sistema educacional, a fim de torná-lo competitivo frente aos mercados americanos e asiáticos. O marco da reestruturação do ensino superior europeu foi a Declaração de Bolonha, em 1999. Colocar este fato histórico no contexto de criação da UFABC é fundamental para compreender seu caráter social, alinhado ao protagonismo europeu neste mesmo quesito.

No Brasil, o trabalho apresenta como primeiro paradigma urbanístico de universidade brasileira, em recorte a partir de 1960, a UnB - Universidade de Brasília, implantada na nova Capital Federal - não apenas como um novo modelo acadêmico-pedagógico (o Departamento; o ensino por módulos), mas também por sua nova forma urbana: o campus moderno. Em seguida, trata-se de contextualizar a situação educacional no Brasil na primeira década do século XXI quando, já em plena democracia com um governo de esquerda, novas reformas educacionais são propostas e é implantado o Programa de Apoio a Planos de Reestruturação e Expansão das Universidades Federais - REUNI -, buscando novos modelos educacionais e introduzindo o cenário de criação da UFABC.

No capítulo 2, o texto mostra como, a partir da desconcentração industrial durante os anos 1970 e 1980, países como Espanha, Itália, Chile, Argentina e Brasil, em especial a RMSP e o ABC Paulista, tiveram de buscar novas respostas institucionais compatíveis com os avanços tecnológicos e as novas formas de produção e acumulação nas cidades. Apresenta o projeto Eixo Tamanduatehy, desenvolvido por urbanistas brasileiros e espanhóis, como resultado da aplicação do Planejamento Estratégico em Santo André, articulado com municípios vizinhos para conjuntamente realizar uma reestruturação econômica, política e social e mostra que, em 1990, o município já se estruturava para receber uma universidade pública na região. Em 2005, é instituída a UFABC, em caráter multidisciplinar ${ }^{2}$, e inicia-se a estruturação física de seus espaços em Santo André, com o lançamento do Concurso Nacional de Projeto Arquitetônicos

\footnotetext{
2 “Essa reorganização contrasta com a matriz clássica das universidades brasileiras, que, em geral, representam o que é adotado em muitos países: física, química, matemática e biologia. O novo método permite que os cursos fundamentais sejam conduzidos por pessoas com diferentes formações (...). As disciplinas podem ser ensinadas, alternativamente, por pessoas com diferentes conhecimentos, com as respectivas ênfases". (UFABC, 2006)
} 
para o campus Santo André que teve grande repercussão, com a participação de 50 escritórios de arquitetura e o projeto declarado vencedor foi concebido por Libeskind Llovet Arquitetos.

Com a criação do campus São Bernardo, em continuidade ao REUNI, a UFABC expandiu sua estrutura para outro município. O projeto arquitetônico do campus São Bernardo, foi resultado de um processo licitatório vencido pelo escritório Benno Perelmutter Arquitetura e Planejamento. Sua concepção foi tratada de forma participativa com a comunidade acadêmica e isso se refletiu na sua construção, possibilitando uma implantação com menos percalços do que aquela ocorrida no campus Santo André.

No capítulo 3, há considerações que apontam o debate sobre a atual estruturação / desestruturação física dos espaços universitários, mesmo reconhecendo a influência das novas tecnologias que cada vez mais relativizam a necessidade de proximidade física para uma integração acadêmica. Também analisa a questão da integração universitária, considerando as relações entre as propostas pedagógicas e o planejamento físico das universidades de Brasília e da UFABC, ambas pioneiras na revisão dos modelos universitários vigentes no país, reconhecendo ainda que uma reflexão sobre os espaços universitários se entrelaça com os ideais de universidade preconizada pelos mestres modernos. 


\section{ANTECEDENTES DA UNIVERSIDADE A PARTIR DE 1960}

\subsection{A busca da integração universitária}

Historicamente a universidade europeia teve origem em instituições de elite, reservadas para a formação dos escalões superiores da sociedade e estreitamente ligada ao poder político e religioso. Após a revolução industrial, esta situação mudou gradualmente e a antiga universidade medieval se abriu para uma crescente burguesia que aspirava a consolidar certos privilégios de classe. Somente após a Segunda Guerra Mundial, as universidades europeias, americanas e de alguns países em desenvolvimento sofreram uma verdadeira revolução que as transformaram em instituições para grandes massas. Em termos quantitativos o número de alunos e escolas foi multiplicado; em termos qualitativos, a universidade deixou de ser um monumento com caráter simbólico para tornar-se uma ferramenta com função social, segundo Guido Canella (1968).

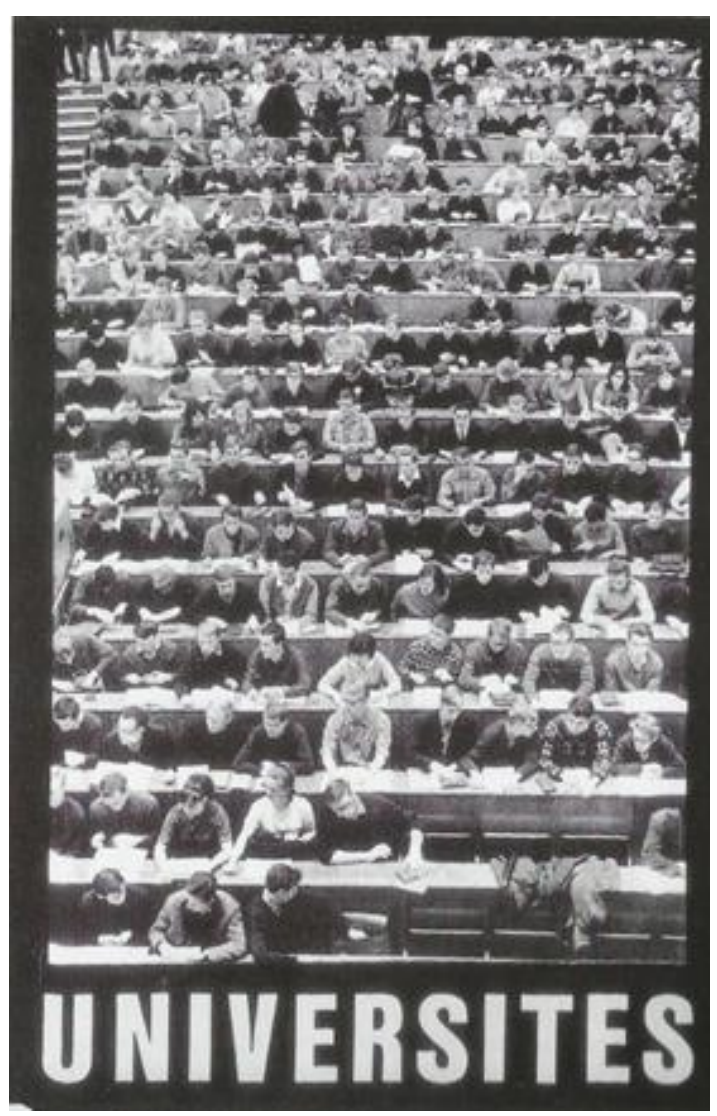

IMAGEM 3 Sorbonne, Paris - Foto de Willy Ronis, 1968. Fonte: Muthesius, S., 2000, pg. 248
Os anos 1960 trouxeram significativas transformações para a sociedade ocidental. Período do chamado baby boom, da Primavera de Praga, do movimento estudantil de maio de 1968, que culminou com a ocupação da Universidade de Nanterre pelos estudantes franceses descontentes com o sistema educacional das universidades, essa década também viu nascerem movimentos culturais nos quais os jovens tiveram um protagonismo marcante.

No bojo desse cenário, marcado pelas ideias libertárias, pelos slogans "É proibido proibir", "Faça amor, não faça a guerra", pelo movimento underground, pelo movimento hippie, o ensino superior foi palco de importantes revisões na estrutura pedagógica, administrativa e física das Universidades. 
A Universidade Moderna trouxe novas perspectivas quando introduziu a integração entre ensino e pesquisa, aspiração de diversos segmentos da sociedade como via para o desenvolvimento científico e tecnológico, conforme apontam Charle e Verger (1994). Nos anos 1960, teve início uma interessante simbiose entre as ciências sociais e a arquitetura. Dada a importância que se atribuiu à infraestrutura física, arquitetônica e urbanística, que incorporou o pensamento estruturalista da época ao programa universitário, a integração dos espaços físicos de uma universidade é validada pela inter-relação da comunidade acadêmica.

Nesse momento, um grupo de arquitetos formado dentro dos Congressos Internacionais de Arquitetura Moderna (CIAM), o Team X3 , que se opunha à ortodoxia do movimento moderno abdicando de suas teorias doutrinárias, destacou-se por querer aproximar o projeto da arquitetura moderna ao mundo da ciência, da tecnologia e da produção, como uma forma de pesquisa, utilizando métodos científicos, experimentais e empíricos. Nesse contexto, a fundação da Universidade Livre de Berlim, no pós-guerra, foi um sinal dos novos tempos. Símbolo de liberdade, flexibilidade e integração, retratou a luta pela autonomia de gestão, sustentada heroicamente por uma cidade dividida. Os arquitetos vencedores do concurso para o projeto, em 1963, Candilis, Josic, Woods e Schiedhelm declararam: "Em toda reflexão sobre o projeto, se levará em conta a dinâmica interna e vitalidade da universidade como um princípio de suas atividades e desenvolvimento". (CASTELLANOS, DOMINGO, \& TORRES, 2011, p. 48).

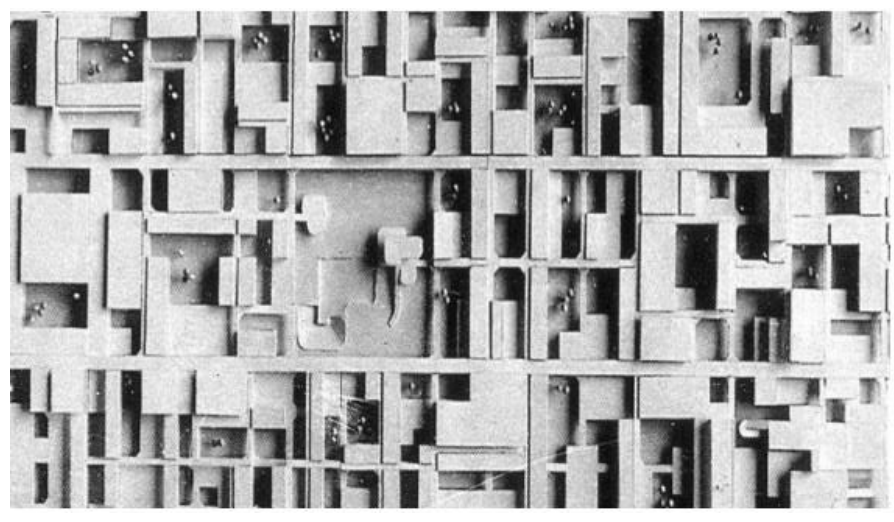

IMAGEM 4 Maquete da Universidade Livre de Berlim e desenhos de Shadrach Woods, 1969.

Fonte: Muthesius, S., 2000.
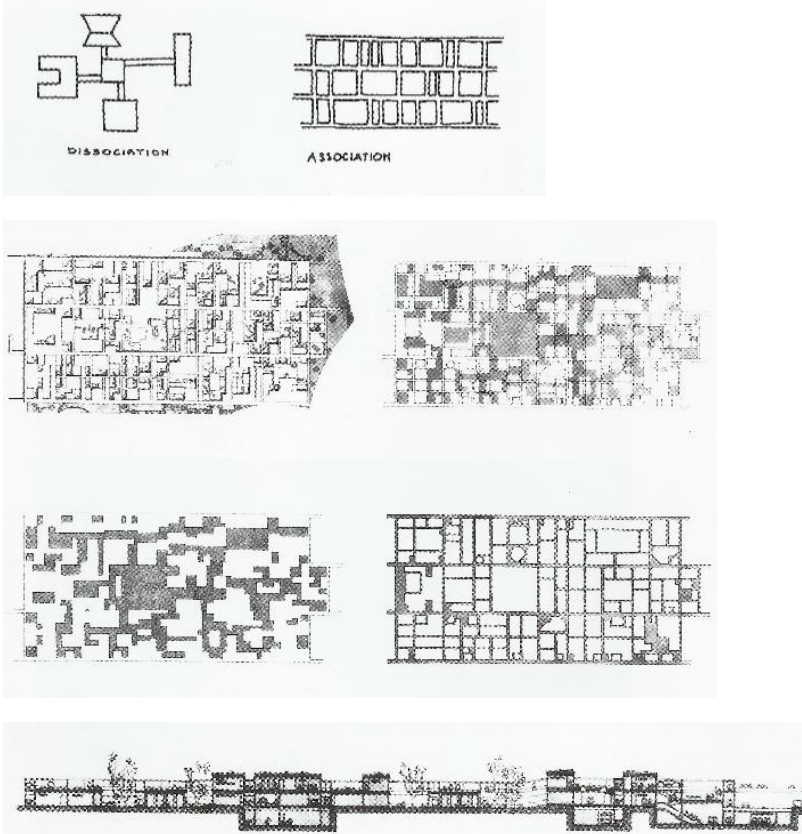

\footnotetext{
${ }^{3}$ Grupo formado pelos arquitetos Peter e Alison Smithson, Aldo van Eick, Jacob Bakena, George Candilis, Shadrach Woods,
} Ralf Erskine e Giancarlo De Carlo. 
Surgiu assim uma nova linguagem: as superestruturas. O livro Megastructure, urban future of the recente past, de Reyner Banham (1976), expôs os projetos extensos e complexos que se tornaram correntes a partir dos anos 1960.

[...]. Segundo o autor (Banham), megaestruturas não seriam apenas edificações de grandes dimensões, para serem categorizadas neste grupo deveriam ser:

1) construídas em unidades modulares;

2) capazes de uma ampliação grande e mesmo "ilimitada";

3) capazes de uma armação estrutural que se pode construir - ou mesmo "plugar" ou "conter" - depois de terem sido pré-fabricadas em outro lugar - unidades estruturais menores (por exemplo, habitações ou pequenas edificações de outra tipologia).

4) uma armação estrutural que pressupõe uma vida útil muito mais longa que a das unidades menores que poderia suportar. (ALBERTO, 2013, p. 4)

Alison Smithson, que tratava as megaestruturas como mat-buildings, ao escrever artigo para a revista britânica Architectural Design (AD 9/74), atribuiu uma mudança de ordem projetual, baseada na interconexão de densos padrões de associação e nas possibilidades de ampliações, reduções e mudanças dos espaços físicos - "características organizacionais que atendem ponto por ponto as exigências de um programa universitário da década precedente". Em seu artigo, a Universidade Livre de Berlim representa o autêntico paradigma do matbuilding. (SMITHSON A. , 1974, p. 18)
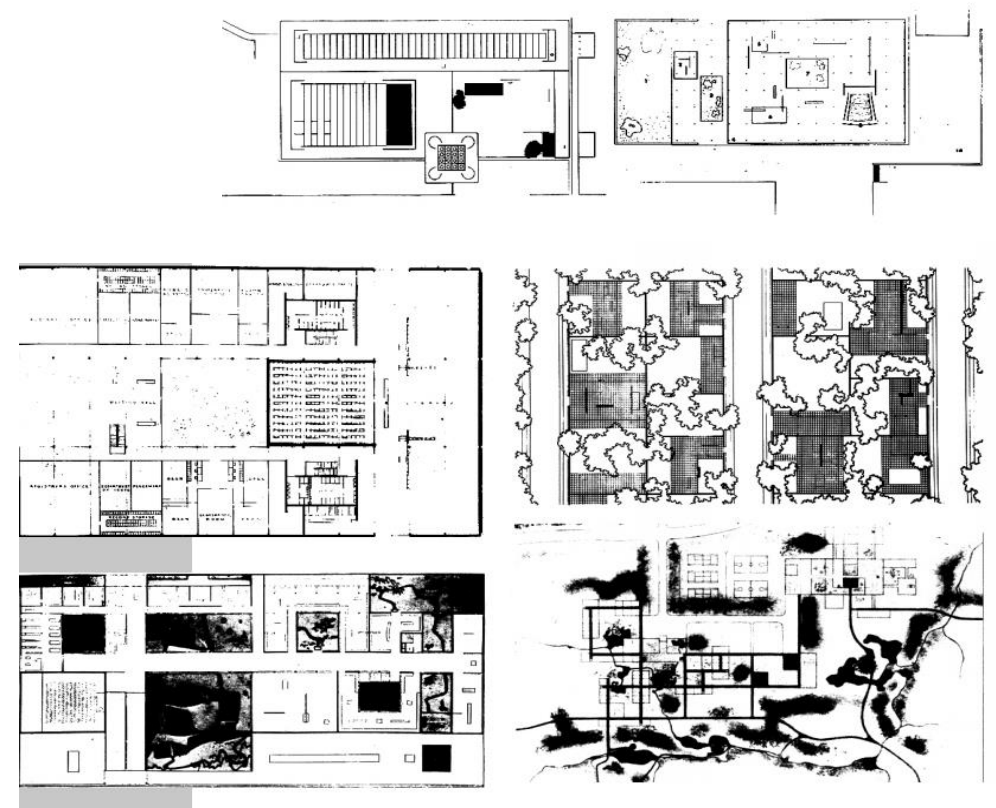

IMAGEM 5 Diagramas das obras de Le Corbusier, Mies Van der Rohe, I.M. Pei.

Alison Smithson defende que a versão construída da Universidade Livre de Berlim permite reconhecer as obras dos grandes mestres antecedentes.

Fonte: Smithson, A., 1974 
O conceito urbanístico da Universidade Livre de Berlim permitiu criar espaços anônimos e coletivos por meio de tecidos urbanos unificados e contínuos, analogamente a um esquema de malha reticulada, compondo uma variedade volumétrica de cheios e vazios, de "ruas e travessas", permitindo ainda todas as modificações necessárias no interior dos "quarteirões", onde surgem espaços livres sob a forma de pátios. As unidades construídas - anônimas - se agregavam em torno de redes de circulação e de acesso. Entretanto, a crítica que recaiu sobre o projeto foi a sua não diferenciação de espaços e funções, desconsiderndo o conceito de planejamento que permitiria, de acordo com Nuno Portas (1968, p. 14), a emergência de arquiteturas mais identificáveis.

IMAGEM 6 Freie Universitat Berlin. Fonte Archdaily, 2017

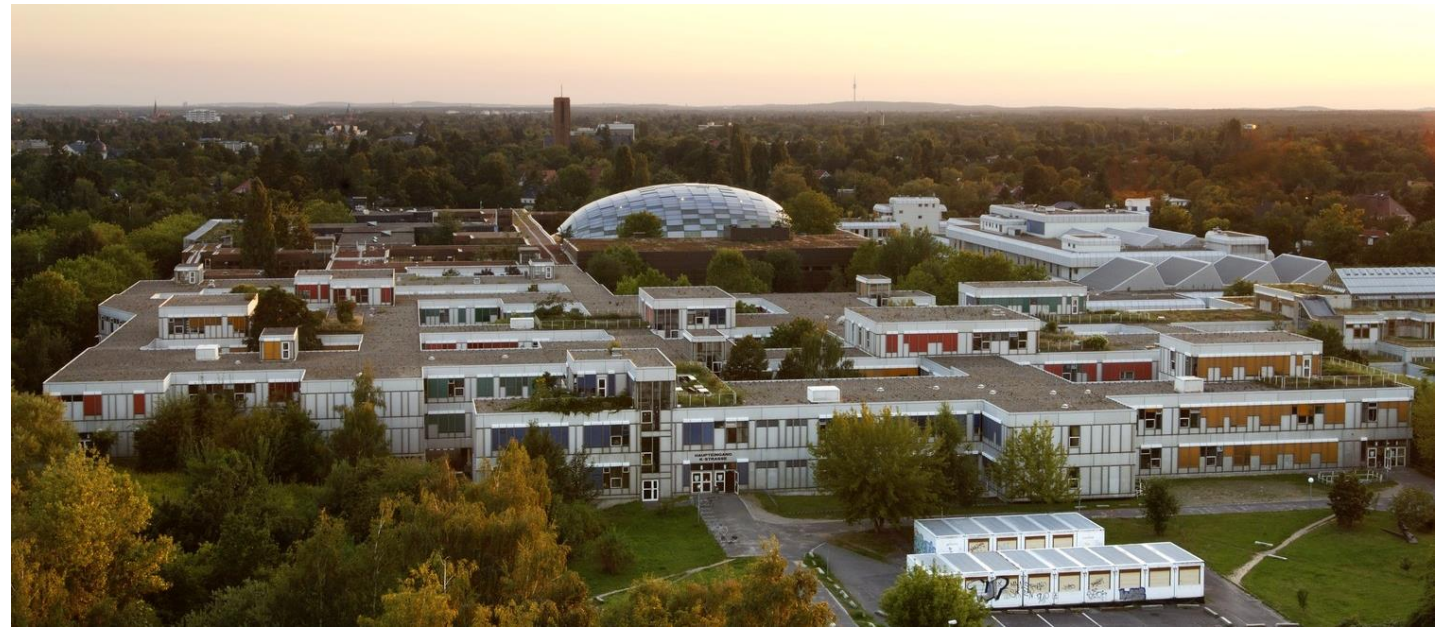

IMAGEM 7 Acesso e pátios - Freie Universitat Berlin. Fotos: Mônica M. Graner
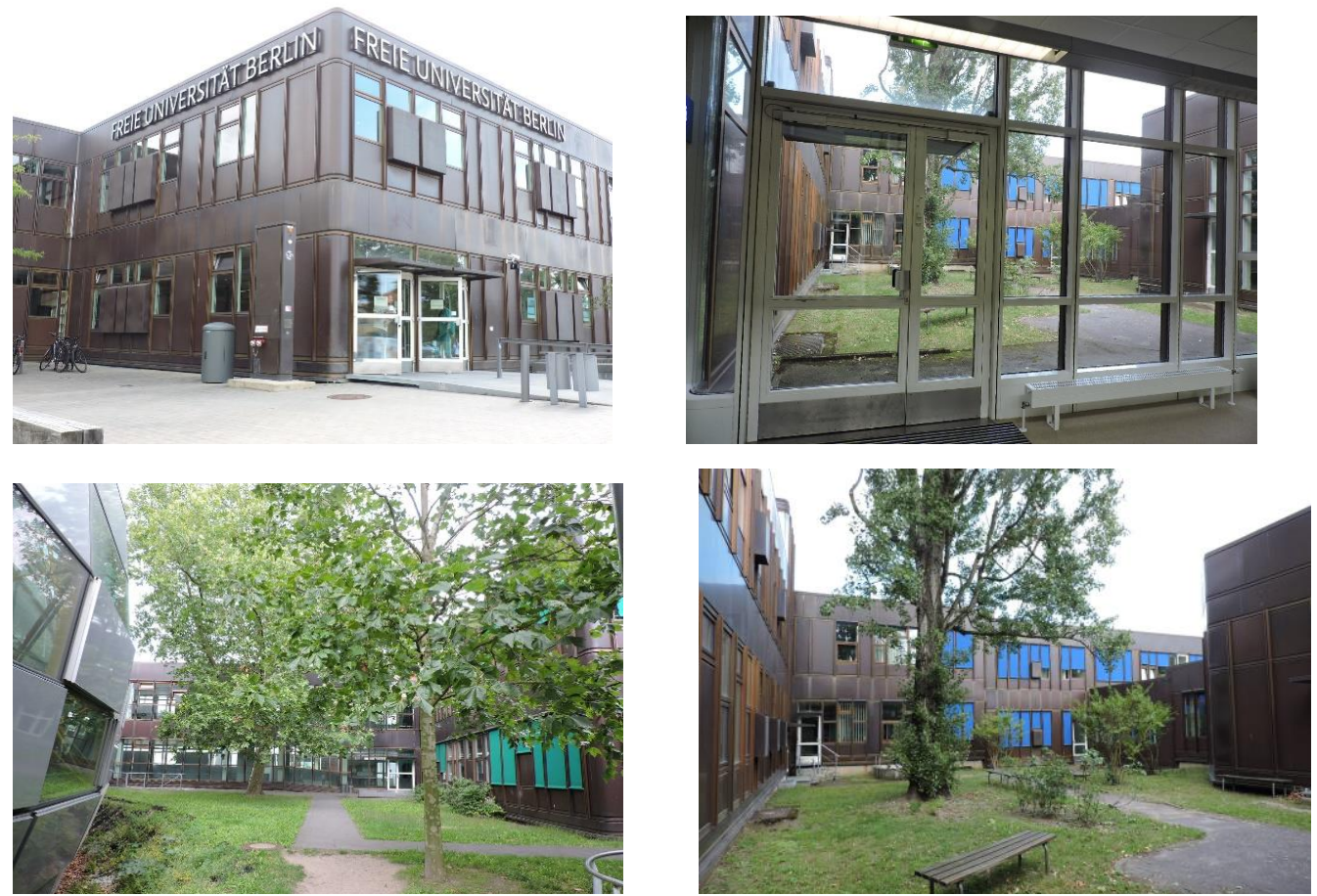
Em abril de 1968, a revista L'Architecture d'Aujourd'Hui publicou uma edição integral sobre o tema Universités. Os arquitetos Emilio Tempia e Guido Canella, responsáveis pela edição, compuseram um panorama de importantes obras, projetos e bibliografia sobre a produção de espaços universitários na Europa e na América nos anos 1960. Fomentaram a pesquisa da arquitetura enquanto disciplina, conforme postulava a universidade moderna, em momento muito favorável à produção arquitetônica de universidades, por meio das construções de megaestruturas, mat-buildings etc. Emilio Tempia $(1968$, p. 6) escreveu em seu artigo que, se há um espaço onde a arquitetura exerce ou amplia seu papel simbólico é certamente aquele dos espaços universitários.

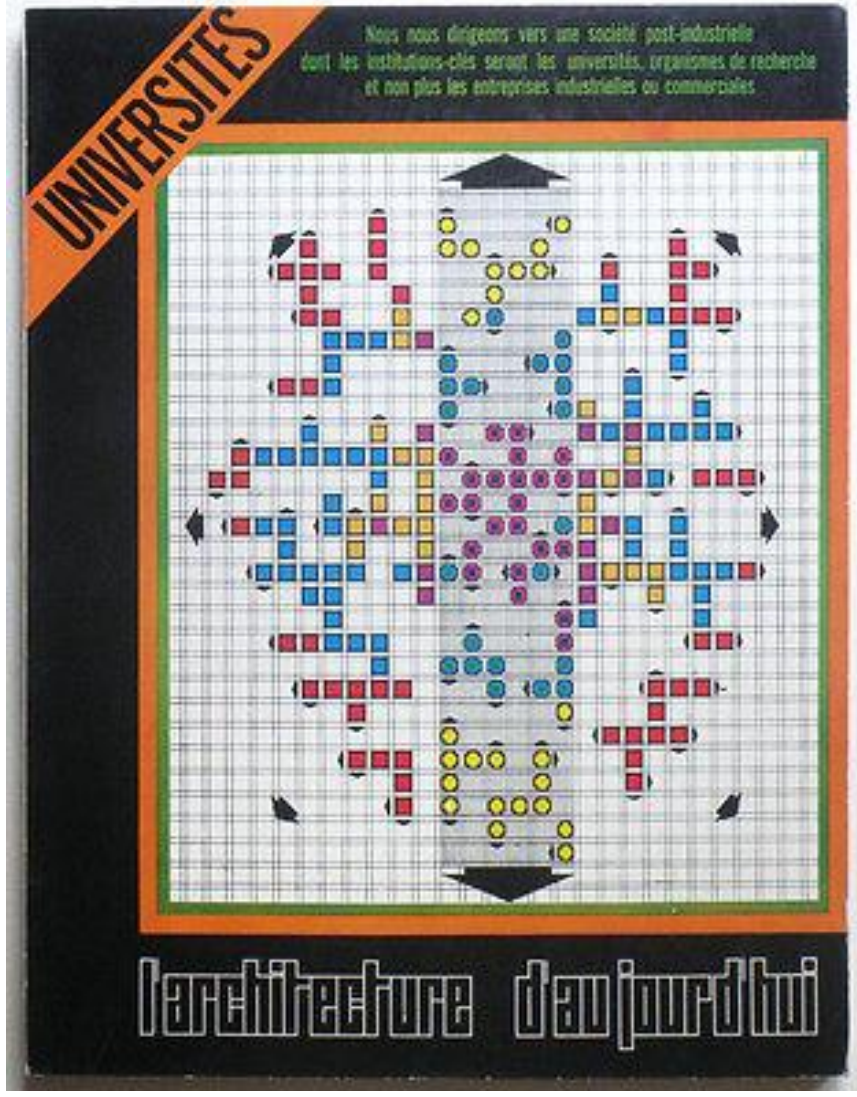

IMAGEM 8 Capa da revista Ad'A 137, 1968.

Fonte Muthesius, S. 2000. Pg 273
A capa da revista mostrava um diagrama do Masterplan da Loughborough University of Technology, projeto de 1966 do grupo inglês Arup Associates, e continha o seguinte texto: "Nós caminhamos rumo a uma sociedade pós-industrial, cujas instituições chaves serão as universidades e organismos de pesquisa e não mais empresas industriais $e$ comerciais" que, sintomaticamente, parecia apontar para essa mesma concepção, na medida em que reconhecia a pesquisa e, por consequência, as universidades como protagonistas desta nova sociedade pós-industrial (ALBERTO, 2015).

Outro debate recorrente era a validação da relação do espaço físico com a integração acadêmica. O editorial de agosto do periódico norte-americano Progressive Architecture, escrito por Walter N. Netsch Jr (1962, p. 130), trazia algumas reflexões sobre as novas formas de ensino com o aumento dos recursos audiovisuais, a demanda por espaços flexíveis e eficiência do uso dos espaços e oportunidades interdisciplinares. Destacavam-se questões como: O planejamento do campus está sendo utilizado para gerar um sentido de comunidade? 
Os problemas de flexibilidade, integração dos serviços técnicos e novas técnicas pedagógicas estão sendo reconsideradas em novas disposições geométricas, ou novos conceitos espaciais? O campus é considerado como uma comunidade para o pedestre, ou mesmo como uma comunidade em qualquer sentido social? É um objetivo da administração e do corpo técnico empreender a reintegração entre a estrutura pedagógica e o entorno físico? Essas indagações sinalizavam que a noção de integração acadêmica foi um dos conceitos de fundo que permearam a formulação do questionário (ALBERTO, 2015).

Para Canella (1968, p. 16), é preciso considerar ainda outras proposições de integração da universidade com a cidade, que se configuram como necessidades objetivas, tais como relações que a instituição deve estabelecer com a infraestrutura de transporte e serviços para otimizar os percursos da população universitária; deve também constituir uma rede para realizar uma integração virtual com as atividades de pesquisa, aplicação e cultura; deve haver um equilíbrio na relação da universidade com a sociedade para garantir uma vida comunitária adequada, dotada de atividades interdisciplinares, culturais, esportivas e de lazer, de forma a promover a aproximação da comunidade.

Giancarlo de Carlo (1919-2005) foi o representante italiano do grupo Team X. Teve seu percurso profissional estreitamente ligado à academia, foi fundador do Laboratorio internazionale di architettura e urbanistica e diretor da revista Spazio e Società. Foi, também, um crítico efusivo da insuficiência e do anacronismo do ensino superior. Interpretava a estrutura universitária italiana como uma pirâmide invertida, na qual todo o corpo acadêmico é sustentado pelo princípio da autoridade e não pelas demandas provenientes dos estudantes, que deveriam ser a base da pirâmide, uma vez que a atividade fim dessa instituição é a formação dos jovens estudantes. De Carlo escreve:

A Universidade italiana contemporânea conserva ainda a hierarquia que the foi imposta na Idade Média pela Companhia de Jesus: aquela conformação autoritária e instrumentalizada que é hoje a principal causa de seu atraso e dificuldades. (DE CARLO, 1968, p. 6)

Embora tenha se projetado internacionalmente por sua atuação no Team X, pertencia antes a outro grupo de intelectuais italianos que se encontrava nas férias de verão, na costa da Ligúria, em um povoado de pescadores chamado Bocca di Magra, que deu nome ao grupo, e era formado por amigos ativistas da resistência Italiana: Elio Vittorini, Vittorio Sereni e Ítalo Calvino entre outros. Aquela paisagem rústica, junto ao mar e ao rio, inspirava-os a um debate 
recorrente sobre a Itália naquele período: o destino das cidades na reconstrução da Europa, as relações entre cidade e campo, entre as cidades antigas e os novos arranjos urbanos, as cidades europeias e as cidades americanas. Vittorini, jornalista e escritor, contava suas viagens pelas cidades do mundo feitas no ano precedente e o tema sobre as cidades nutria todos. Como resultado, Vittorini escreveu um romance publicado postumamente, sob o título Le Cittá del Mondo, no qual todos os personagens são viajantes contínuos; Ítalo Calvino escreveu suas fábulas em Le Cittá Invisibili. Para De Carlo, estas duas obras foram, na sua pesquisa sobre as cidades e o território, seus livros de referência. (1998, p. 207)

É nos anos 1960 que se inicia sua maior e mais longa experiência projetual e construtiva: as intervenções na Universidade de Urbino, visando à sua renovação. Em consequência de uma parceria bem-sucedida entre Prefeito, Reitor e arquiteto, De Carlo vai além da Universidade: suas intervenções passam para a cidade, culminando no Plano Regulador de Urbino, iniciado em 1964 e editado em 1966 com muita repercussão na Itália, por definir uma metodologia precisa de recuperação de cidade histórica em face das mudanças físicas, econômicas e sociais da atualidade (MCKEAN, 2004, p. 31).

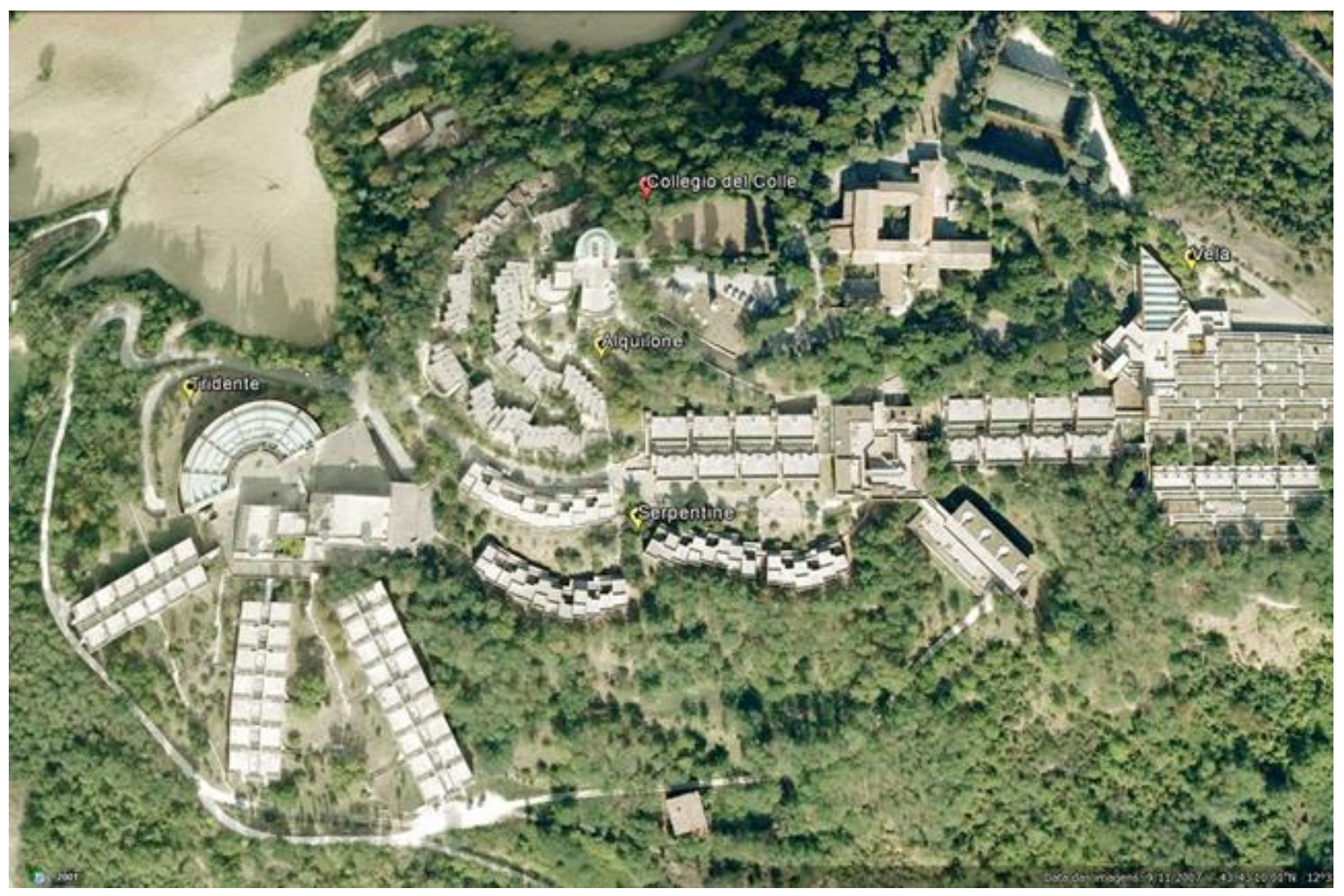

IMAGEM 9 Residências estudantis projetadas por Giancarlo De Carlo em Urbino, It. Foto Google Earth set/2016 

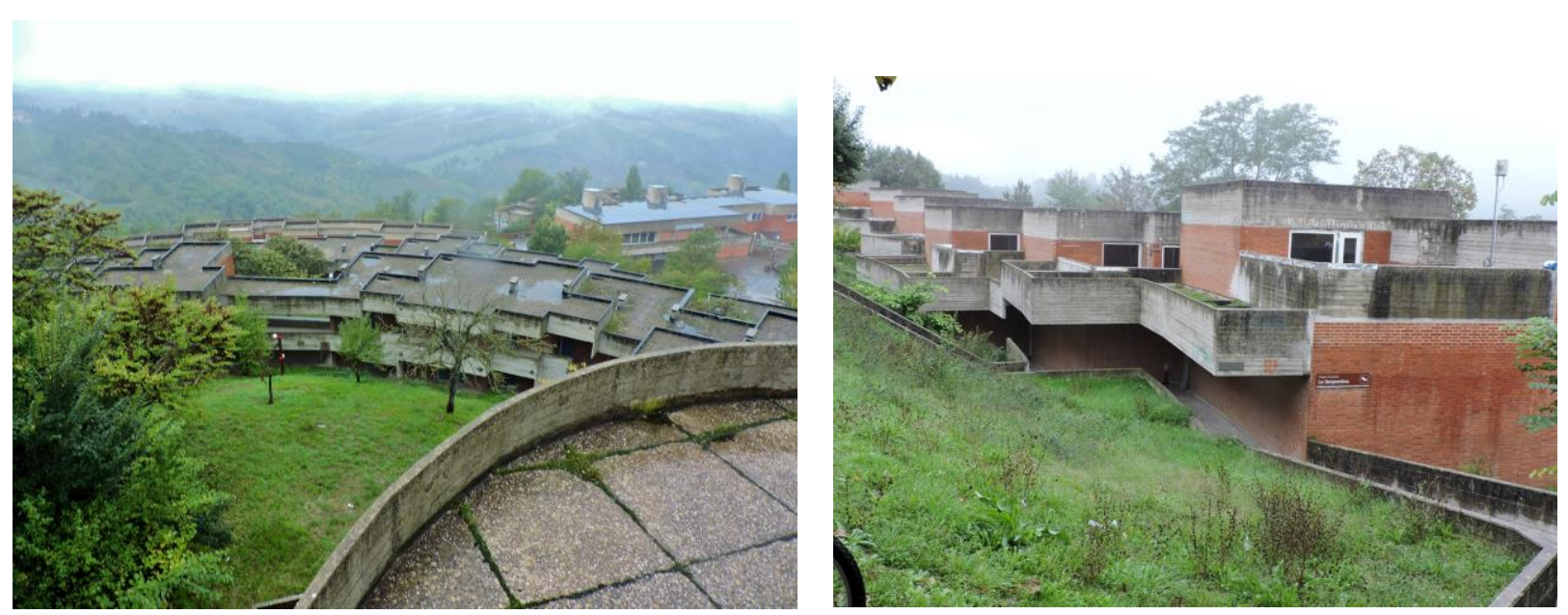

IMAGEM 10 Residências Estudantis Urbino. Foto: Monica M. Graner

De Carlo sempre esteve engajado na defesa da cidade, do resgate da vida urbana pela recuperação de edifícios e dos tecidos urbanos históricos. Seus projetos são "cidadelas" onde cada volume é considerado como o centro de uma rede de relações e se desenvolve como uma narrativa revelando possibilidades de expansão infinita. Assim, transformou não só a realidade dos locais onde interveio como também a realidade da paisagem e do patrimônio sociocultural que herdou. Assim como Ernesto Nathan Rogers (1909-1969), defendia a recuperação do sentido de tradição e história (conceitos relegados pelo movimento moderno), buscando harmonizar seus projetos às preexistências ambientais (MONTANER, 2007, p. 85).

Destaca-se ainda, nesse período, outro arquiteto que se dedicou à reflexão da relação entre pesquisa científica e pesquisa projetual na arquitetura: Vittorio Gregotti (1927-). Ele experimentou, com certa insistência, tendências compositivas simétricas inseridas em vários contextos urbanos e paisagísticos, racionalizando métodos de produção projetual (BENEVOLO, 2007) (BENEVOLO, 2007, p. 63). Um exemplo é a Universitá della Calabria (UNICAL), megaestrutura aplicada aos espaços universitários, projetada V. Gregotti e equipe composta por E. Purini, E. Battisti, H. Matsui, P. Nicolin e C.R. Clerici, vencedora do concurso em 1972. Trata-se de uma sucessão de edifícios departamentais modulares conectados em uma estrutura tipo ponte, que Gregotti chama de "faixa de assentamento", de 1.110 metros de extensão interligando as colinas de Arcavacata, na cidade de Cosenza, onde ações positivas no âmbito do ensino superior eram prementes. 


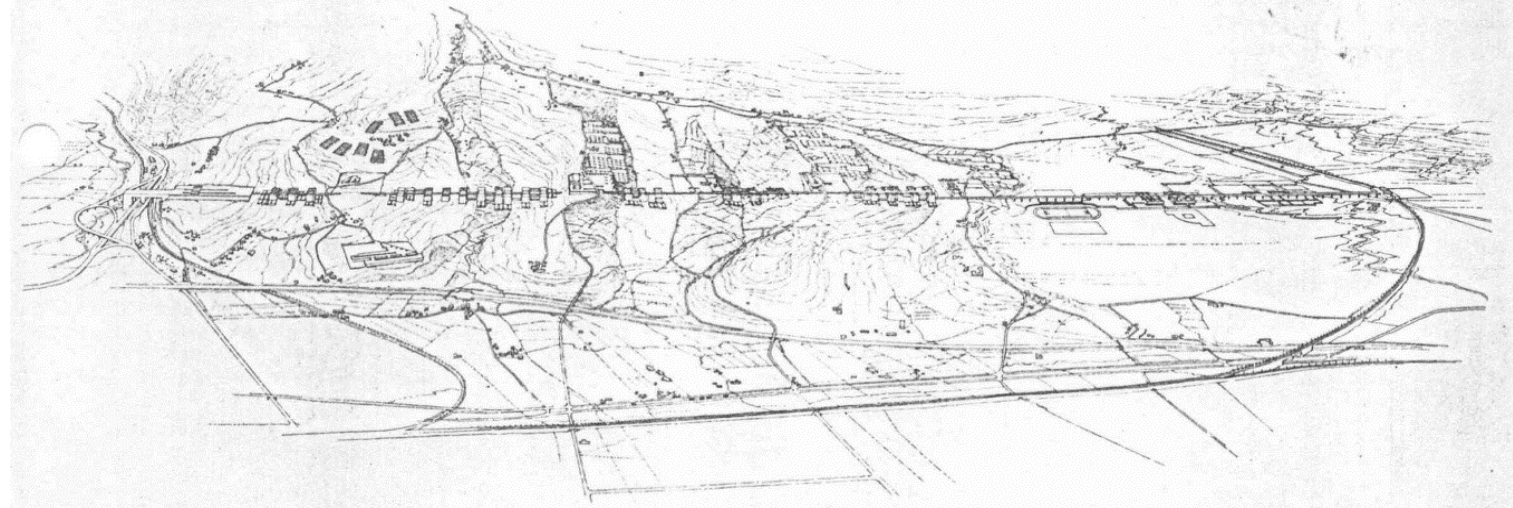

IMAGEM 256 Croquis da implantação da Universidade da Calábria. Fonte: Portal unical.it, 2016

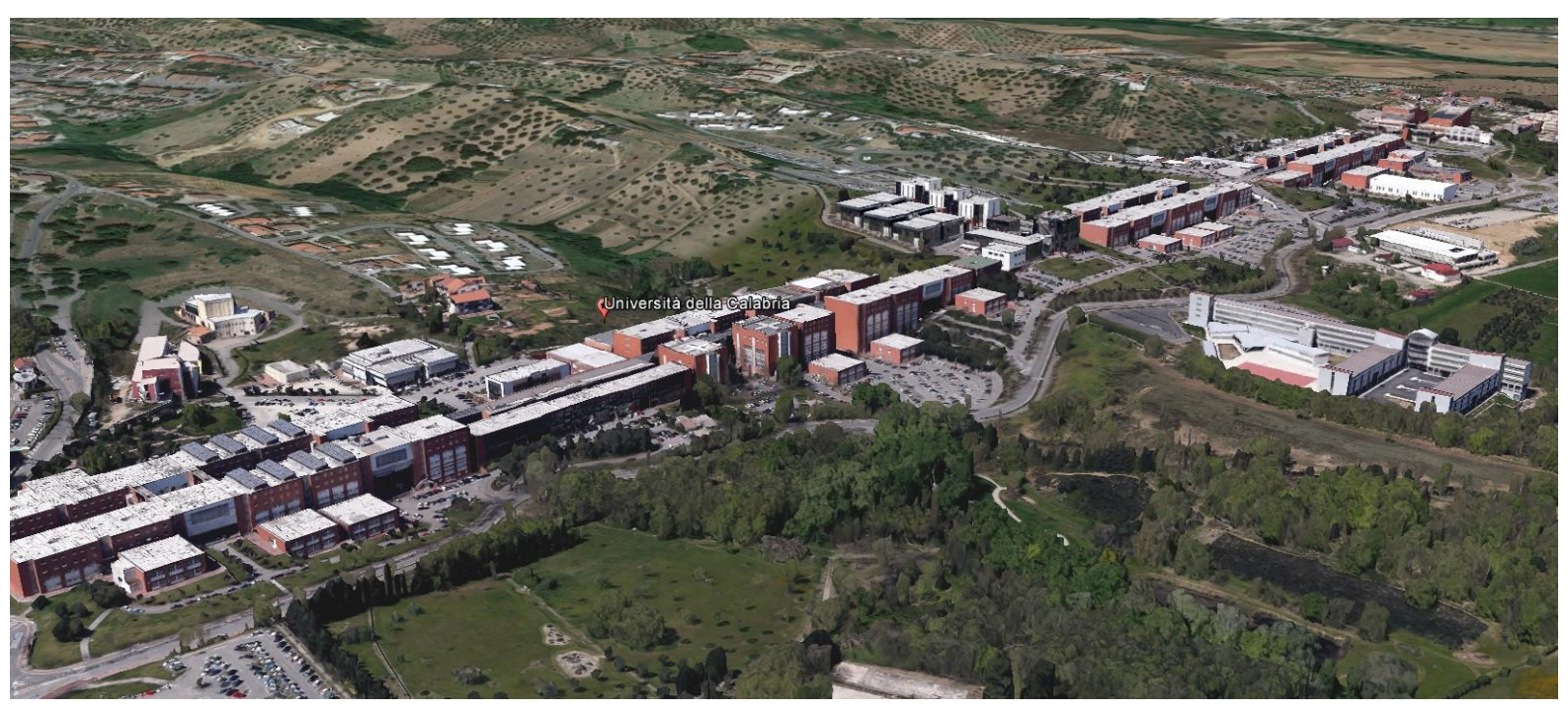

IMAGEM 257 Vista da Universidade da Calabria. Foto Google Earth, 2017

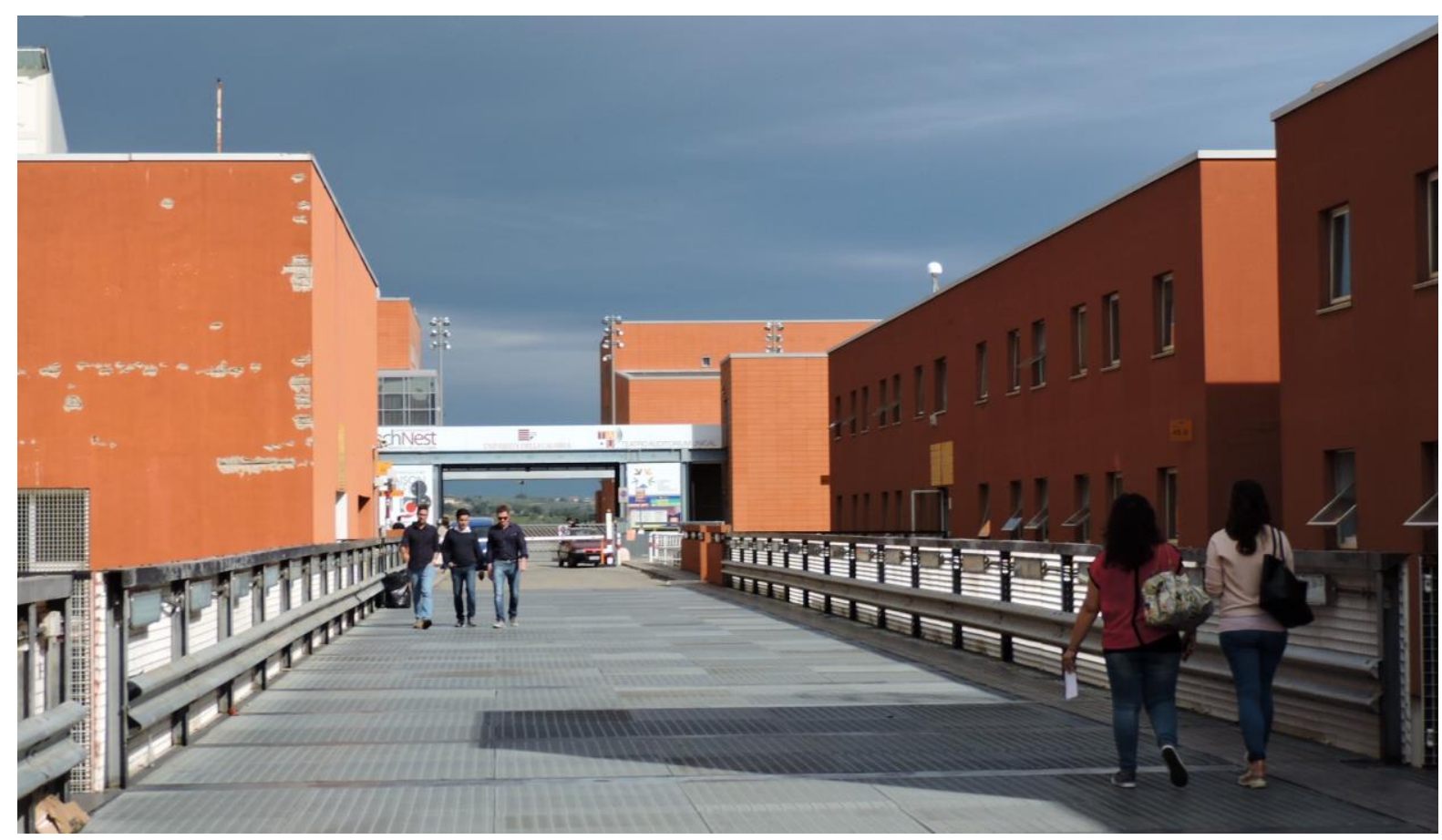

IMAGEM 13 UNICAL - Via ponte. Foto: Mônica M. Graner,2015 
Nesse projeto, ele propõe ainda criar uma interação entre morfologia e funcionalidade, geografia e arquitetura:

O ambiente compõe-se dos vestígios de sua própria história. Por isso, se é na geografia que os sinais da história se consolidam e sobrepõem numa forma, o projeto arquitetônico tem a missão de chamar a atenção para a essência do contexto ambiental por meio da transformação da forma ${ }^{4}$.

Para Stefan Muthesius, a Universidade da Calábria é um dos exemplos no qual o sistema das megaestruturas chegou ao seu extremo. Ele considera que o concurso de Cosenza pode ter sido o ponto final de uma década das grandiosas estruturas internacionais.

O panorama apresentado até o momento representa uma pequena parcela das intervenções emblemáticas nos espaços universitários nos anos 1960 e 1970 na Europa. Dentre as universidades citadas, a Universidade Livre de Berlim é a que, hoje, passa por uma intensa revitalização nos seus espaços, pois está em processo de restauro e renovação, com a construção da biblioteca de filologia, projetada por Norman Foster. A Universidade de Estudos de Urbino tem uma situação mais delicada devido à falta de recursos para manter o conjunto residencial estudantil, ainda que a cidade tenha se beneficiado muito com a revitalização da instituição e com a intensificação da vida urbana dessa pequena cidade histórica. Vittorio Gregotti teve sérias divergências com a direção da Universidade da Calábria - UNICAL -, para fazer prevalecer seu projeto original e afastou-se da construção dos edifícios mais recentes da universidade 5

Depois da revolução dos anos 1960, a Europa passou por uma revisão do seu sistema educacional a partir dos anos 1990, em razão da unificação europeia.

\subsection{O Processo de Bologna}

A globalização é um conceito recente, que surgiu há pouco mais de duas décadas, dividindo os estudiosos quanto às suas características e compreensão.

No entanto, qualquer que seja sua conceituação, é fato que o avanço nas comunicações, criando incontáveis fontes de informação e proporcionando amplo acesso a elas, provocou

\footnotetext{
${ }^{4}$ Cf. GREGOTTI, V. Territorio e arquitetura. In: NESBITT, K. Uma nova agenda para a arquitetura. São Paulo: Cosac Naify, 2013, p. 372-376

${ }^{5}$ Em visita a UniCal, em outubro de 2015, entrevistei o professor Gabrio Celani, diretor do Laboratório de Urbanística que participou do Concurso da Unical, em 1972. Ele conta que, desde 1995, Gregotti se desligou da obra.
} 
fortes alterações na sociedade e gerou consequências para a educação, quaisquer que sejam os níveis considerados e, em especial, para o ensino superior.

Grandes transformações no setor educacional ocorreram na Ásia, provocando forte desenvolvimento social. Nos EUA, o modelo adotado parece ter se tornado o mais competitivo no nível mundial, atingindo $80 \%$ da população escolar na maior parte do país e, em algumas universidades, a oferta $100 \%$ dos cursos na modalidade a distância ${ }^{6}$.

Para enfrentar a defasagem de seu sistema de ensino superior, com relação a esses modelos, a Comunidade Econômica Europeia (CEE) iniciou um processo de reformulação desse nível, de modo a torná-lo mais compatível com o mundo que se projetava para o século XXI. Chamado de Processo de Bolonha é um documento conjunto assinado pelos Ministros da Educação de 29 países europeus, reunidos na cidade italiana de Bolonha. A declaração marca uma mudança em relação às políticas para a educação superior dos países envolvidos e estabelece um espaço europeu de Ensino Superior em comum, a partir do comprometimento dos países signatários em promover reformas, por meio do estabelecimento de um sistema de créditos transferíveis e acumuláveis, também comum aos países europeus, para promover a mobilidade estudantil. Previa a adoção de um sistema baseado em três ciclos de estudos ${ }^{7}$.

O procedimento de implantação desse modelo, ainda em curso, visa garantir ao estudante europeu a legitimação e a mobilidade acadêmica dentro de qualquer país da comunidade europeia, assegurar que o sistema europeu de Ensino Superior consiga adquirir um elevado grau de atração mundial e aumentar as chances de empregabilidade dos estudantes diplomados. Nesse processo, foram delineados os seguintes objetivos:

i. Adoção de um sistema baseado em dois ciclos acadêmicos principais: a graduação (com duração mínima de três anos) e a pós-graduação, cujo acesso deve ser antecedido pelo êxito no primeiro ciclo, conduzindo aos graus de mestre ou doutor, após dois ou três anos, respectivamente;

ii. Estabelecimento de um sistema de créditos transferíveis e acumuláveis, comum aos países europeus, a fim de promover uma maior mobilidade dos estudantes. Espera-se que os créditos possam ser adquiridos, também, em contextos de "ensino não

\footnotetext{
${ }^{6}$ Cf. FARIA, D. S., \& MAIA, D. M. Universidade Nova do Brasil e o Processo de Bologna na Comunidade Européia. 2012. Disponível em: Rede Livre: http://flacso.redelivre.org.br. Acesso em: 21/05/2017.

7 Ibidem.
} 
superior", incluindo a aprendizagem ao longo da vida, desde que sejam reconhecidos pelas respectivas Universidades de acolhimento;

iii. Promoção da mobilidade dos estudantes (no acesso às oportunidades de estudo e formação, bem como a serviços correlatos), dos professores, dos pesquisadores e do pessoal administrativo, com programas integrados de estudo, pesquisa e formação; e

iv. Promoção da cooperação interinstitucional na avaliação da qualidade dos cursos oferecidos, com vista a desenvolver critérios e metodologias comparáveis ${ }^{8}$.

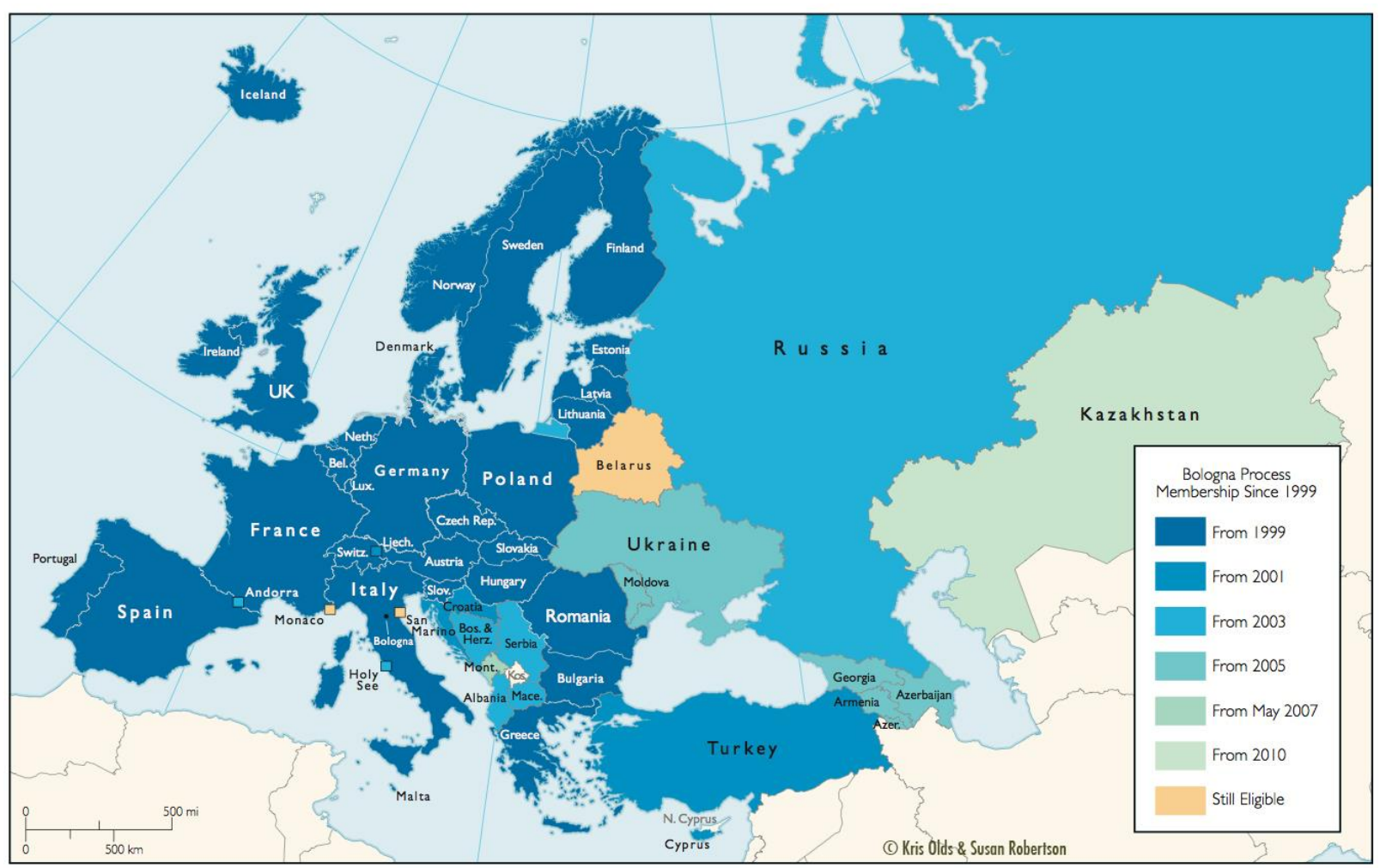

IMAGEM 14 Mapa dos países que aderiram ao Processo de Bolonha.

Disponível em https://globalhighered.wordpress.com/2011/04/20/mapping-bologna-process-membership

A expansão desse Processo atingiu, até o presente, 45 países $^{9}$. Os ministros presentes ao encontro concordaram que o período 2005-2007 deveria estar voltado à implementação e consolidação dos processos de reforma existentes, não sendo oportuna, por hora, a introdução de novas linhas de ação. Além disso, o Grupo de Acompanhamento do Processo de Bolonha comprometeu-se a:

\footnotetext{
${ }^{8}$ Cf DECLARAÇÃO de Bolonha. Disponível em:

http://antigo.ufabc.edu.br/images/stories/pdfs/declaracaodebolonhaportugues.pdf. Acesso em: 16/01/2017.
}

${ }_{9}$ Adesões subsequentes: Albânia, Andorra, Armênia, Azerbaijão, Bósnia, Croácia, Chipre, Geórgia, Macedônia, Moldova, Montenegro, Rússia, Santa Sé, Sérvia, Turquia e Ucrânia. 
- Reforçar a dimensão social do Processo de Bolonha;

- Remover os obstáculos à mobilidade dos estudantes, professores, pesquisadores e pessoal administrativo até 2007;

- Implementar as linhas orientadoras da gestão/certificação da qualidade;

- Implementar as estruturas nacionais de qualificação;

- Criar e reconhecer diplomas conjuntos; e

- Criar percursos flexíveis de aprendizagem no ensino superior.

A dimensão social do Processo de Bolonha é um aspecto que adquire cada vez mais importância entre os Estados-membros da reforma universitária europeia, sobretudo no que diz respeito a questões relativas às bolsas, às condições de vida dos estudantes e docentes, às formas de acesso e à mobilidade acadêmica, uma vez que países com realidades econômicas e sociais muito distintas fazem parte dessa iniciativa.

Atualmente o Processo de Bolonha está em revisão ${ }^{10}$. Em 2016, o Reino Unido optou, por meio de um plebiscito, por sair da Comunidade Econômica Europeia. As implicações e os impactos dessa decisão no ensino superior são incalculáveis, dado que as contruibições em termos de recursos humanos e finaceiros do Reino Unido para o ensino e a pesquisa sempre foram muito expressivos. Como se vê, há ainda um longo caminho a percorrer e a Universidade é constantemente desafiada a mudar para permanecer relevante e ativa num mundo em mutação.

No Brasil, o período equivalente, a partir dos anos 1960, foi marcado por intenso desenvolvimento industrial e, no âmbito acadêmico, manifestava-se uma profunda necessidade de revisão da estrutura acadêmica e espacial nas universidades. Diferente dos países europeus, não havia uma verdadeira tradição universitária a defender, melhorar ou preservar (RIBEIRO, 1962). A construção de Brasília motivou a fundação de uma universidade modelo, que veio a ocorrer com a Universidade de Brasília em 1961. No entanto, o exilio de seu idealizador, Darcy Ribeiro, em função da ditadura - entre outros motivos, comprometeu a implantação do projeto original, frustrando as várias tentativas de reformas nas décadas de 60 e 70, do século XX. 


\subsection{A Universidade de Brasília}

Durante o governo de Juscelino Kubitschek (1956 -1960), o desenvolvimento industrial brasileiro ganhou novos rumos e feições. JK abriu a economia para o capital internacional, atraindo indústrias multinacionais. Foi durante este período que ocorreu a instalação de montadoras de veículos internacionais (Ford, General Motors, Volkswagen e Willys) em território brasileiro, especificamente no ABC paulista.

Em seu plano de governo, visava a avançar o país "cinquenta anos em cinco", reunindo trinta metas em cinco setores: energia, transporte, alimento, indústria de base e educação, sua trigésima meta.

(...) em matéria de ensino superior: aumentar para mil novos alunos por ano a capacidade as escolas de Engenharia; instituir o regime de tempo integral dos professores e da frequência obrigatória dos alunos; reformar o ensino superior, visando a organizar os cursos de acordo com suas finalidades e as necessidades do meio em que operam; e criar novos cursos de pós-graduação e aperfeiçoamento. Para esse objetivo, o Governo instalará 14 Institutos de Pesquisas, Ensino e Desenvolvimento nos principais centros do país, nos setores de química, economia, tecnologia rural, mecânica, eletrotécnica, mineração e metalurgia, mecânica agrícola, matemática, física, genética e geologia. (BRASIL, 1958)

A Universidade de Brasília (UnB), inaugurada em abril de 1962, foi a precursora de um modelo que intentou implantar um caráter universal e integrado à estruturação da universidade brasileira. A equipe de concepção do projeto pedagógico, que reunia docentes e cientistas, foi coordenada por Darcy Ribeiro e Anísio Teixeira e ambos vieram a ser reitores na primeira e segunda gestão, respectivamente, dessa instituição. A UnB representou a busca de um modelo de produção do conhecimento necessário ao desenvolvimento científico, tecnológico e econômico do país. Naquela década foram criadas as agências de fomento à pesquisa como a Coordenação de Aperfeiçoamento de Pessoal de Nível Superior (Capes), o Conselho Nacional de Desenvolvimento Científico e Tecnológico (CNPq).

A UnB foi uma universidade sem precedentes; os projetos social, pedagógico e físico foram totalmente planejados desde o início, tal como a recém-inaugurada cidade onde se inseria, Brasília. A proposta pedagógica, que integrava ensino, pesquisa e extensão, foi definidora dos programas arquitetônicos e do projeto de implantação do campus.

O projeto da UnB teve, no campo da arquitetura e do urbanismo, atores importantes que contribuíram para a consolidação do pensamento moderno no Brasil: Lúcio Costa lançou o projeto de implantação do conjunto e, posteriormente, Oscar Niemeyer desenvolveu os 
projetos para diversos edifícios que iriam compor sua estrutura física, destacando-se o Instituto Central de Ciências.

A proposta espacial deste novo modelo baseava-se na ideia de campi universitários. Estas estruturas promoveriam a proximidade e a facilidade de circulação entre estudantes e professores incentivando um sólido intercâmbio científico e cultural e promovendo a tão almejada integração universitária ${ }^{11}$.

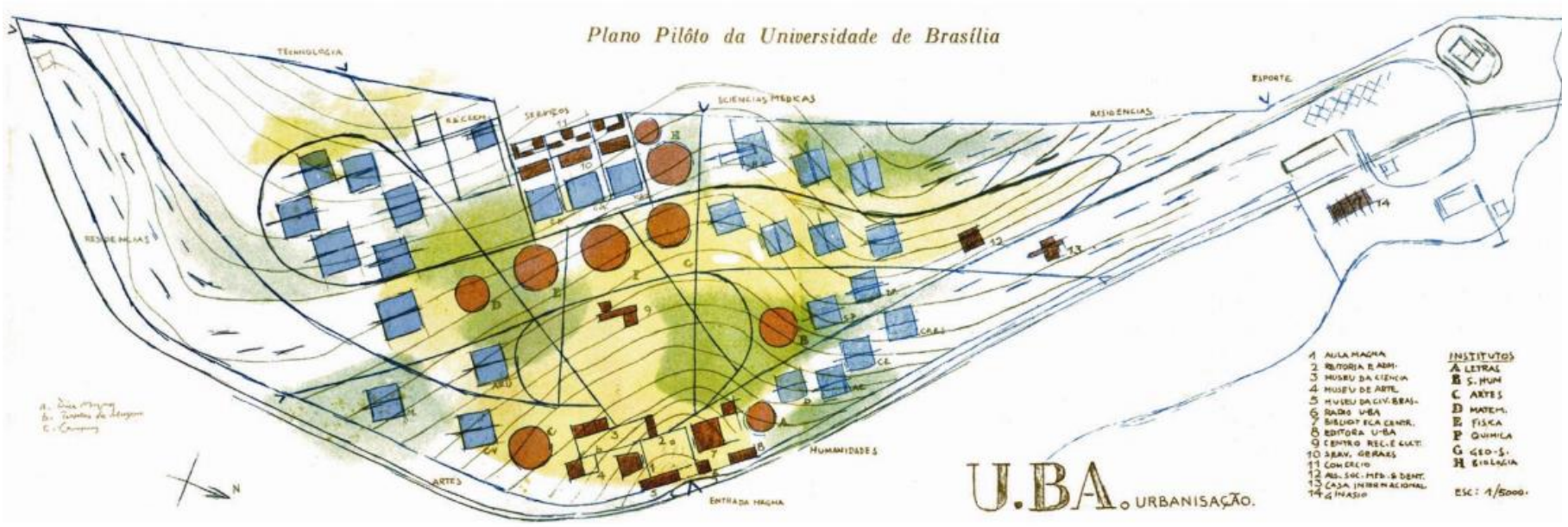

IMAGEM 15 Plano de Urbanização da Universidade de Brasília, Lucio Costa, 1962.

Fonte: Mahler, C.,2015

Em 1963 foi criado, na UnB, o CEPLAN - Centro de Planejamento, cuja finalidade foi promover o desenvolvimento de estudos, plano e projetos no âmbito da universidade. Foi chefiado por Oscar Niemeyer que trabalhou com o arquiteto João Filgueiras Lima, o Lelé. O tempo exíguo para a construção e a necessidade de racionalização de processos construtivos levaram os arquitetos a viabilizarem sistemas de pré-fabricação, tecnologia do concreto e da argamassa armada. Niemeyer efetuou alterações que levaram a um deslocamento do centro do campus para um grande edifício alongado - Instituto Central de Ciências -, com 720 metros de extensão, ocupação nas extremidades e circulação central. O ICC passou a ser o elemento estruturador do plano, ilustrado na Imagem 16.

${ }^{11}$ Cf. Alberto (2015). 


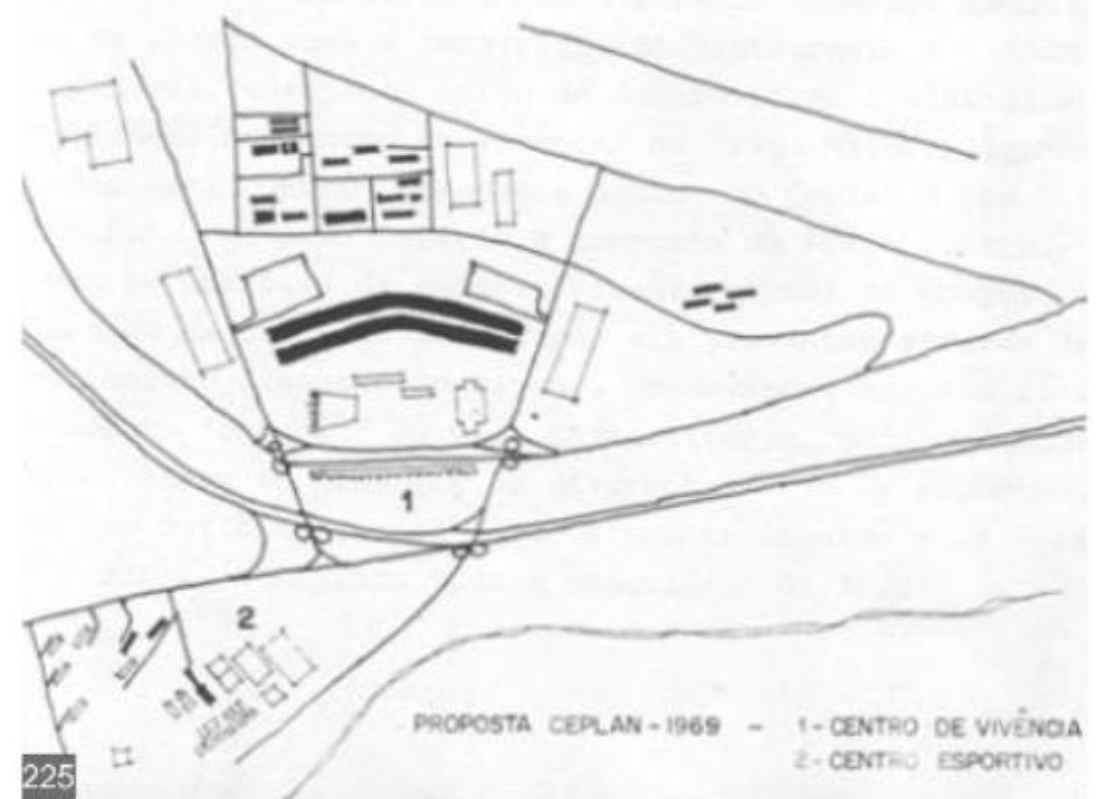

IMAGEM 16 Estudo urbanístico campus UnB, 1969 Fonte CEPLAN.1972 In Mahler, 2015
"O Instituto Central de Ciências assume [...] papel dos mais expressivos, representando também por suas dimensões proposta espacial, solução estrutural e conceito de integração, um exemplo para outras universidades. (ACRÓPOLE, 1970, p. 18)

O edifício contemplava a proposta de integração da universidade e ali instituíram-se os cursos de Ciências Exatas, Letras, Arquitetura, Economia, Historia. Com a Reforma Universitária de 1968 e o abandono da proposta pedagógica instalada, seu uso foi paulatinamente alterado e adaptado. A obra foi finalizada somente em 1975.

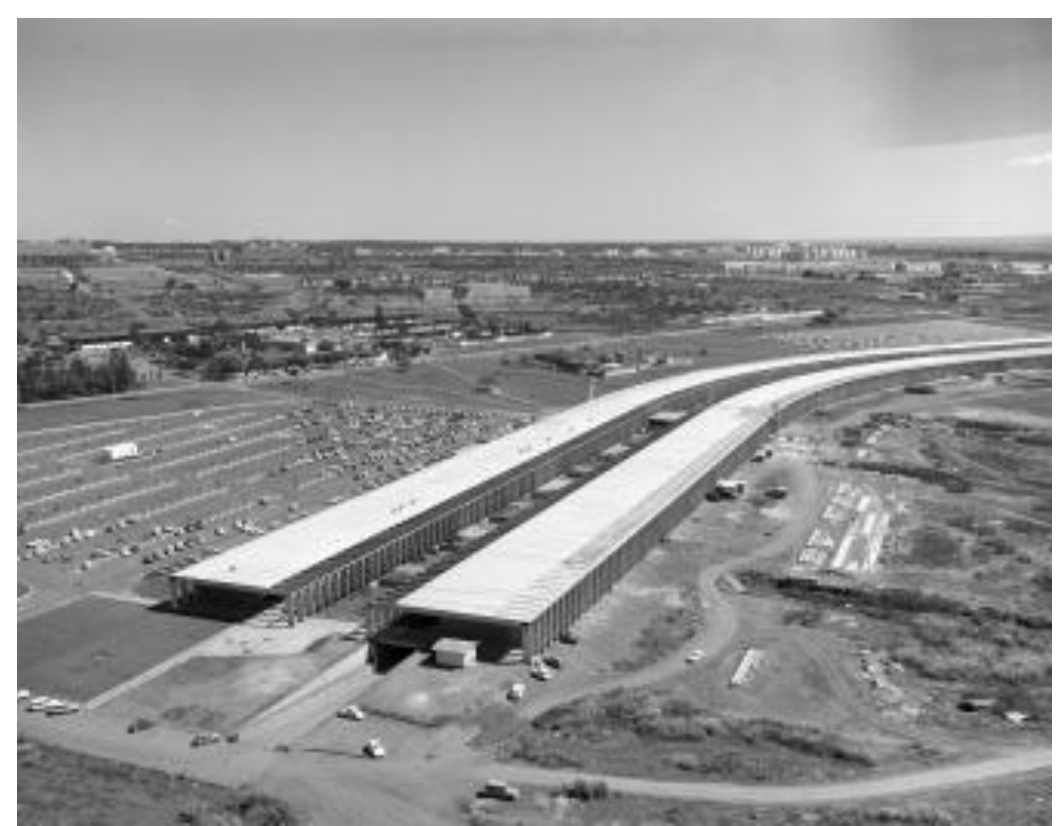

IMAGEM 17 Vista do Instituto Central de Ciências - ICC

Fonte: www.museuvirtualdobrasil.com.br

A Reforma Universitária de 1968 - Lei 5540, de 28/11/68, propôs, entre outros pontos, a implementar a experiência da UnB e estendê-la às demais universidades no país. Nos três 
anos que se seguiram à Reforma, foram criadas 11 universidades, das quais 8 são federais. Assim como os esforços se deram no sentido de integrar pedagógica e academicamente as atividades de ensino, fisicamente também procurou-se integrar os diversos cursos. De início, havia as faculdades isoladas espalhadas pela cidade. Com a criação das universidades perseguese a implantação dos edifícios em um só local - a cidade universitária. O modelo vai se alterando em direção a outra morfologia - o campus universitário, culminando com as intenções preconizadas a partir de 1968.

A diferença entre os dois modelos está clara nos conceitos apresentados pelo americano Rudolf Atcon (1970), convidado a ser consultor quando do planejamento de alguns campi pós-Reforma, e do qual depreendemos as seguintes definições:

Cidade Universitária: corresponde à universidade tradicional - dá, em uma só área geográfica, a expressão física ao desejo de união das unidades isoladas e dispersas que a compõem. Não ultrapassa, porém, uma mera aproximação dos edifícios que abrigam autarquias independentes entre si;

Campus Universitário: um local geográfico que reúne todas as atividades de uma universidade e as integra de maneira mais econômica e funcional em atendimento acadêmicocientifico coordenado e da maior envergadura possível, resguardadas as limitações de seus recursos humanos, técnicos e financeiros.

Num primeiro momento, a criação da universidade se pauta pelo esforço de integrar instituições que se encontravam espargidas pela malha urbana. Num segundo momento, com a Reforma Universitária, esse esforço é ampliado, uma vez que se propôs a racionalização administrativa, a criação de institutos básicos, a troca do sistema de Cátedras pela estruturação em Departamentos.

Como forma de viabilizar os pressupostos da Reforma Universitária, o Governo Federal contratou do Banco Interamericano de Desenvolvimento (BID) grande soma de recursos. Tal aporte financeiro com o BID pretendia atuar no fortalecimento da universidade, a partir de 4 suportes: edificações, equipamentos, assistência técnica e capacitação de pessoal.

Assim, ao longo doas anos 1980, são criadas outras 26 universidades, sendo apenas 7 públicas (e apenas 2 federais) e a metade delas no Estado de São Paulo.

Segundo Gustavo A. G. Oliveira (2010, p. 15), em 1962, o governo federal planejou fundar a Universidade Federal de São Paulo, na região do ABC. O professor Fausto Castilho foi convidado para compor um conselho universitário para a nova instituição. Trabalhou-se 
durante cinco meses na concepção de uma universidade nova, que teria como modelo a recéminaugurada Universidade de Brasília, até que, em abril de 1964, o Ministro Gama e Silva, nomeado pelos militares após o golpe, extinguiu e encerrou definitivamente o projeto da Universidade Federal de São Paulo no ABC.

\subsection{A Expansão do Sistema Federal de Educação Superior 2003-2014 $4^{12}$}

No governo do presidente Fernando Henrique Cardoso (1995-2002), foi sancionada a Lei no 10172, em 2001, que aprovou o Plano Nacional de Educação (PNE 2001-2011). Tal documento, elaborado a cada dez anos, traça diretrizes e metas para a educação em nosso país, com o intuito de que sejam cumpridas até o fim desse prazo. No que concerne à educação superior, o Plano estabeleceu, dentre outras metas, o provimento da oferta da educação superior para, pelo menos, 30\% dos jovens na faixa etária de 18 a 24 anos, até o final da década ${ }^{13}$.

Quando Luiz Inácio Lula da Silva assumiu a Presidência, as políticas públicas para educação definidas a partir de 2003 alinharam-se aos ditames do Plano Nacional de Educação, na tentativa de o governo de atender às reivindicações e expectativas de diversas entidades da sociedade civil, pela ampliação de oferta de vagas no ensino superior federal.

Dentro da estrutura do Ministério da Educação, cujo ministro era Tarso Genro (20042005), coube à SESu - Secretaria de Educação Superior - as políticas de implantação nos setores público e privado. Em 2004, o secretário da SESu, o engenheiro Nelson Maculan Filho, ex-reitor da UFRJ, cientista e educador, solicitou, em 2004, um estudo sobre a reforma universitária à Academia Brasileira de Ciências $(A B C)$ da qual também era membro. A Academia criou um grupo de trabalho, ao qual pertencia o professor Luiz Bevilacqua, cientista conhecido por seu trabalho como Presidente da Agência Espacial Brasileira e que viria a ser o responsável pela implantação da UFABC, para analisar e fazer propostas no que concerne à reestruturação do ensino superior. O resultado foi o documento Subsídios Para a Reforma do Ensino Superior ${ }^{14}$, que adotava uma postura crítica com relação à estrutura universitária do país, na qual o aluno faz a opção por um curso específico, já no concurso de ingresso, e durante o qual

12 Cf. BRASIL. A democratização e expansão da educação superior no país 2003-2014. Brasília: MEC SESu, 2015. Disponível em: http://portal.mec.gov.br/index.php?option=com docman\&view=download\&alias=16762-balanco-social-sesu-20032014\&ltemid=30192 Acesso em: 27/05/2016

${ }_{13}$ Cf. BRASIL. Lei no 10172/2001. Disponível em: http://portal.mec.gov.br/arquivos/pdf/L10172.pdf Acesso em: 26/05/2016

${ }^{14}$ Cf. ACADEMIA BRASILEIRA DE CIÊNCIAS. Subsídios para a Reforma do Ensino Superior. 2004. Disponível em:

http://www.abc.org.br/IMG/pdf/doc-29.pdf. Acesso em: 27/05/2016 
recebe formação excessivamente especializada em uma grade curricular rígida. Tal documento foi a cartilha para a implantação do projeto pedagógico da UFABC.

Outras entidades também manifestaram suas posições ao MEC, com destaque à Associação Nacional dos Dirigentes das Instituições Federais de Ensino Superior (Andifes), por meio da Proposta de Expansão e Modernização do Sistema Público Federal de Ensino Superior ${ }^{15}$. Somam-se a esse movimento o Sindicato Nacional dos Docentes das Instituições de Ensino Superior (Andes-SN), a Federação dos Sindicatos dos Trabalhadores das Universidades Públicas Brasileiras (Fasubra) e a União Nacional dos Estudantes (UNE) ${ }^{16}$.

Durante os mandatos do governo Lula, de 2003 a 2011, seus Ministros da Educação foram Cristovam Buarque (2003-2004), Tarso Genro (2004-2005) e Fernando Haddad (20052011). Ainda em consonância com PNE e com as demandas das entidades e sociedade civil, o MEC estabeleceu uma visão sistêmica da educação, atuando da creche à pós-graduação.

O professor Dilvo Ristoff assim se manifestou a respeito do ensino superior brasileiro:

Poderíamos dizer que a imagem de futuro está centrada no programa de governo do Presidente Lula, que estabelece como um de seus compromissos básicos "o reconhecimento do papel estratégico das universidades, em especial as do setor público, para o desenvolvimento econômico e social do país". Na verdade, quando atentamos para os números do Censo, percebemos que as universidades representam uma parcela ínfima do total de IES (8,4\%). Isto significa dizer que $91,6 \%$ das instituições constitucionalmente não têm a obrigação de realizarem atividades de pesquisa ou extensão e não necessitam preocupar-se com mestrados, doutorados ou estudos aprofundados. Os números indicam que $67,8 \%$ das instituições são pequenas faculdades isoladas com até 1.000 estudantes, fato que escapa à maioria das pessoas, acostumadas a ver na grande mídia o vestibular das universidades públicas, ou a agressiva publicidade de universidades cujas matrículas se aproximam ou mesmo superam a casa dos 100.000 estudantes. É, pois, no contexto de um sistema de educação superior centralizado, privatizado, diversificado, elitista e excludente, aparentemente grande, mas extremamente pequeno para as dimensões do Brasil que precisamos discutir as propostas apresentadas no plano de governo. Esta contextualização é fundamental para a construção de ações que privilegiem o sonho de uma educação superior mais democrática e inclusiva, sem perder de vista as restrições, empecilhos e dificuldades impostos pela realidade. (2006, p. 25)

Esse depoimento tem importância na medida em que alerta para o insignificante número de instituições que se dedicam à pesquisa no Brasil.

\footnotetext{
15 ANDIFES. Proposta de expansão e modernização do sistema público federal de ensino superior encaminhada ao Senhor Presidente da República Luiz Inácio Lula da Silva pela ANDIFES. Disponível em:

http://www.andifes.org.br/wp-content/files flutter/1363027779Proposta expansao Lula.pdf Acesso em 26/05/2016

${ }^{16}$ Cf. BRASIL. Análise sobre a Expansão das Universidades Federais: 2003-2012. Rel. Comissão MEC. Brasília, 2012a. Disponível em: http://portal.mec.gov.br Acesso em: 26/05/2016
} 
Durante a gestão de Fernando Haddad, marcada por políticas de inclusão social, foi criado o Programa Universidade para Todos (ProUni), que, em janeiro de 2012, atingiu, segundo dados do governo federal, a marca de um milhão de bolsas de estudos concedidas a estudantes de baixa renda em instituições privadas, nas quais o benefício é concedido pelas faculdades privadas em troca de incentivos fiscais. O estudante precisa ter estudado em escolas públicas e atender a critérios específicos de renda.

Soma-se a essas ações a criação do Exame Nacional do Ensino Médio (ENEM) que, mais tarde, passou a ser utilizado parcial ou integralmente como prova de admissão aos cursos superiores, em universidades federais e privadas, em substituição ao vestibular. Por meio da criação do SiSU, o Sistema de Seleção Unificada, uma plataforma online para instituições públicas de ensino superior, é possível utilizar o desempenho do estudante no ENEM como critério de entrada. Ao final da gestão Haddad, o Brasil havia aumentado o investimento público em educação de 3,9\% para 5,1\% do produto interno bruto $^{17}$, segundo o MEC.

Para viabilizar as metas de ampliação das ofertas de vagas nas universidades e as mudanças estruturais necessárias, adotou-se como estratégia a expansão física das universidades existentes e a criação de novos campi.

A relação de novas universidades e ampliação de campi, bem como de municípios atendidos ficou assim estabelecida:

\begin{tabular}{|l|c|c|c|}
\hline \multicolumn{3}{|c|}{$\begin{array}{c}\text { Panorama da Expansão da Rede Federal de Ensino } \\
\text { Superior 2002-2013 }\end{array}$} \\
\hline & 2002 & 2010 & 2013 \\
\hline Universidades & 45 & 59 & 63 \\
\hline Campus/Unidades & 148 & 274 & 321 \\
\hline Municipios Atendidos & 114 & 230 & 275 \\
\hline
\end{tabular}

IMAGEM 18 Tabela da expansão das IFES.

Fonte: CENSO/2013-Inep

A expansão foi concebida em três fases e teve como resultado, no decorrer do período, a criação de 18 novas IFES - Instituições Federais de Ensino Superior, distribuídas no território nacional, abaixo relacionadas:

\footnotetext{
17 BRASIL. Haddad atende todos os níveis de educação. Brasília, 2012b. Disponível em: http://portal.mec.gov.br Acesso em:
} $26 / 05 / 2016$ 


\begin{tabular}{|c|c|c|c|c|}
\hline & IFES & NOME DA IFES & REGIÃO & LEI DE CRIAÇÃO \\
\hline 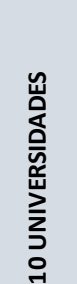 & $\begin{array}{l}\text { UNIFAL } \\
\text { UFVJM } \\
\text { UFTM } \\
\text { UFERSA } \\
\text { UTFPR }\end{array}$ & $\begin{array}{l}\text { Universidade Federal de Alfenas } \\
\text { Universidade Fed. dos Vales Jequitinhonha e Mucuri } \\
\text { Universidade Federal do Triângulo Mineiro } \\
\text { Universidade Federal Rural do Semi-árido } \\
\text { Universidade Tecnológica Federal do Paraná }\end{array}$ & $\begin{array}{l}\text { SE } \\
\text { SE } \\
\text { SE } \\
\text { SE }\end{array}$ & $\begin{array}{l}\text { Lei } n=11.154 \text { de } 29 / 07 / 2005 \\
\text { Lei } n=11.173 \text { de } 06 / 09 / 2005 \\
\text { Lei } n=11.152 \text { de } 29 / 07 / 2005 \\
\text { Lei } n=11.155 \text { de } 29 / 07 / 2005 \\
\text { Lei } n=11.184 \text { de } 07 / 01 / 2005\end{array}$ \\
\hline Dे & UFABC & Fundação Universidade Federal do ABC & SE & Lei no 11.145 de $26 / 07 / 2005$ \\
\hline $\begin{array}{l}\frac{\mathbf{c}}{\tilde{u}} \\
\frac{1}{u} \\
\frac{u}{4}\end{array}$ & $\begin{array}{l}\text { UFGD } \\
\text { UFRB } \\
\text { UFCSPA } \\
\text { UNIPAMPA }\end{array}$ & $\begin{array}{l}\text { Fundação Universidade Fed. de Grande Dourados } \\
\text { Universidade Federal do Recôncavo da Bahia } \\
\text { Fundação Univ. Fed. de Ciências da Saúde de Porto Alegre } \\
\text { Fundação Universidade Federal do Pampa }\end{array}$ & $\begin{array}{l}\text { CO } \\
\text { NE } \\
\text { S }\end{array}$ & $\begin{array}{l}\text { Lei } n=11.153 \text { de } 29 / 07 / 2005 \\
\text { Lei } n=11.151 \text { de } 29 / 07 / 2005 \\
\text { Lei } n=11.641 \text { de } 11 / 01 / 2008 \\
\text { Lei } n=11.640 \text { de } 11 / 01 / 2008\end{array}$ \\
\hline 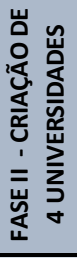 & $\begin{array}{l}\text { UFFS } \\
\text { UFOPA } \\
\text { UNILA } \\
\text { UNILAB }\end{array}$ & $\begin{array}{l}\text { Universidade Federal da Fronteira Sul } \\
\text { Universidade Federal do Oeste do Pará } \\
\text { Universidade Federal da Integração Latino-Americana } \\
\text { Universidade da Integração Internacional da Lusofonia } \\
\text { Afro-Brasileira }\end{array}$ & $\begin{array}{l}\mathrm{S} \\
\mathrm{N} \\
\mathrm{SE}\end{array}$ & $\begin{array}{l}\text { Lei } n=11.029 \text { de } 15 / 09 / 2009 \\
\text { Lei } n=12.085 \text { de } 05 / 11 / 2009 \\
\text { Lei } n=12.189 \text { de } 12 / 01 / 2010 \\
\text { Lei } n=12.289 \text { de } 20 / 07 / 2010\end{array}$ \\
\hline 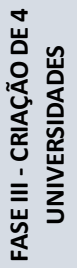 & $\begin{array}{l}\text { UFOB } \\
\text { UFESBA } \\
\text { UNIFESSPA } \\
\text { UFCA }\end{array}$ & $\begin{array}{l}\text { Universidade Federal do Oeste da Bahia } \\
\text { Universidade Federal do Sul da Bahia } \\
\text { Universidade Federal do Sul Sudeste do Pará } \\
\text { Universidade Federal do Cariri }\end{array}$ & $\begin{array}{l}\text { NE } \\
\text { NE } \\
\text { NE }\end{array}$ & $\begin{array}{l}\text { Lei } n^{\circ} 12.825 \text {, de } 05 / 06 / 2013 . \\
\text { Lei } n^{\circ} 12.818 \text {, de } 05 / 06 / 2013 . \\
\text { Lei } n^{\circ} 12.824 \text {, de } 05 / 06 / 2013 . \\
\text { Lei } n^{\circ} 12.826 \text {, de } 05 / 06 / 2013 .\end{array}$ \\
\hline
\end{tabular}

IMAGEM 19 Novas IFES.

Fonte: Simec/MEC

\section{Fase I - Interiorização - 2003 a 2007}

Na Fase I, a prioridade do processo de expansão foi reduzir as assimetrias regionais responsáveis pela concentração das universidades federais em metrópoles e regiões com maior poder aquisitivo. Nesse sentido, entre 2003 e 2007, foram criadas dez universidades federais em regiões prioritariamente não metropolitanas, dentre as quais 40\% na região sudeste, 30\% na região sul, $20 \%$ na região nordeste e $10 \%$ no centro-oeste.

Na prática, a criação de novos campi pautou-se especialmente pela participação das universidades no desenvolvimento regional, por meio da integração com a comunidade local e da participação efetiva das universidades no desenvolvimento da formação profissional e da pesquisa regionais ${ }^{18}$. 
A Universidade Federal do ABC, cujo projeto de implantação estava sendo gerado desde 2004, foi o empreendimento mais significativo dentre todas as novas universidades. Foi escolhida para ser a referência, o carro-chefe da expansão das universidades federais. A região com o maior parque industrial do país desde 1960, clamava por uma retribuição e um estimulo para manter-se atrativa para novos polos de desenvolvimento. Em 2005, foi aprovada a lei para sua criação, que se deu no município de Santo André, motivada por razões que serão vistas adiante.

\section{Fase II - Reestruturação e expansão - 2008 a 2012}

A Fase II da expansão das universidades foi marcada pela criação do Programa de Apoio a Planos de Reestruturação e Expansão das Universidades Federais, o REUNI, pelo Decreto no 6.096/2007, e tinha como objetivo principal criar condições para a ampliação do acesso e da permanência na educação superior, no nível de graduação presencial, pelo melhor aproveitamento da estrutura física e de recursos humanos existentes nas universidades federais. Foram seis diretrizes que nortearam o conjunto de ações do REUNI:

I - Aumento do número de matrículas;

II - Ampliação da mobilidade estudantil, com a implantação de regimes curriculares e sistemas de títulos flexíveis, baseados no aproveitamento de créditos e na circulação de estudantes entre instituições, cursos e programas de educação superior

III - Revisão da estrutura acadêmica, buscando a constante elevação da qualidade;

IV - Diversificação das modalidades de graduação;

V - Ampliação de políticas de inclusão e assistência estudantil;

VI - Articulação da graduação e da pós-graduação com a educação básica.

Nesta fase, a SESu desenvolveu um processo de integração regional e internacionalização da educação superior, por meio da criação de quatro universidades que integram os estados fronteiriços da região sul do Brasil, a região amazônica, os países da América Latina e os países falantes da língua portuguesa em outros continentes, como África e Ásia. Cabe mencionar a criação da Universidade Federal da Integração Latino-Americana, com a missão de formar recursos humanos aptos a contribuir com a integração latino-americana, com o desenvolvimento regional e com o intercâmbio cultural, científico e educacional da América Latina, especialmente no Mercosul, bem como a Universidade da Integração Internacional da Lusofonia Afro-Brasileira, que nasceu da ideia de integrar a educação superior 
brasileira aos países membros da Comunidade dos Países de Língua Portuguesa (CPLP), em especial com o continente africano.

Aqui é importante identificar que o REUNI, em nome da integração regional, propagou um modelo de universidade multicampi, que foi amplamente difundido na Fase II do plano de expansão, permitindo que as IFES se expandissem por meio de unidades menores:

O conceito de universidade multicampi é basicamente o de uma instituição que, sendo uma única pessoa jurídica, mantém mais de dois campi separados, o que pode se aplicar a hospitais, clínicas, institutos de ensino e outras (JIN; WANG, 2010). O nome multicampi, quando aplicado especificamente à instituição Universidade, tende a ser interpretado de maneira simplista, numérica e geograficamente, como se essa denominação servisse simplesmente para denominar aquela que possui diversas instalações do tipo campus. No entanto, outros autores revelam que a expressão multicampi se refere a um modelo específico de universidade muito diferente do tradicional, não apenas no sentido de maior número de campi, mas em complexidade, estrutura, gestão, administração acadêmica ou metodologia pedagógica. ${ }^{19}$

Por seu caráter multicampi e atendendo às demandas da Presidência, o MEC e o grupo dirigente da Universidade Federal do $A B C$, iniciou as tratativas para a expansão da UFABC, no município de São Bernardo do Campo, dentro dos parâmetros do REUNI.

\section{Fase III - Desenvolvimento regional e programas especiais - 2012 a 2014}

A fase da expansão universitária encerrada no final de 2014 compreendeu a criação de 47 novos campi e quatro novas universidades sendo três delas na Bahia e uma no Pará20. 0 ciclo pautou-se não somente pela implantação de novas unidades, mas também pela implementação de políticas específicas de integração, fixação e desenvolvimento regional, tais como o Programa de Expansão do Ensino Médico, que autorizou e incentivou a criação de vagas nos cursos de graduação em Medicina em diversas universidades federais, por meio da instalação de novos cursos e da expansão da oferta em cursos existentes.

Segundo o balanço social do SESu, em 2014, a realidade quantitativa das ações do MEC pôde ser traduzida nas imagens abaixo:

\footnotetext{
19 BAMPI, Aumeri Carlos; DIEL, Jeferson Odair. O modelo multicampi de universidade e suas relações com a sociedade. 2013. Disponível em: https://repositorio.ufsc.br/bitstream/handle Acesso em: 22/06/2016

${ }^{20}$ BRASIL. Balanço Social SESu 2003 a 2014. Brasília: Simec/MEC, 2014. Disponível em: http://portal.mec.gov.br/ Acesso em $12 / 08 / 2016$
} 


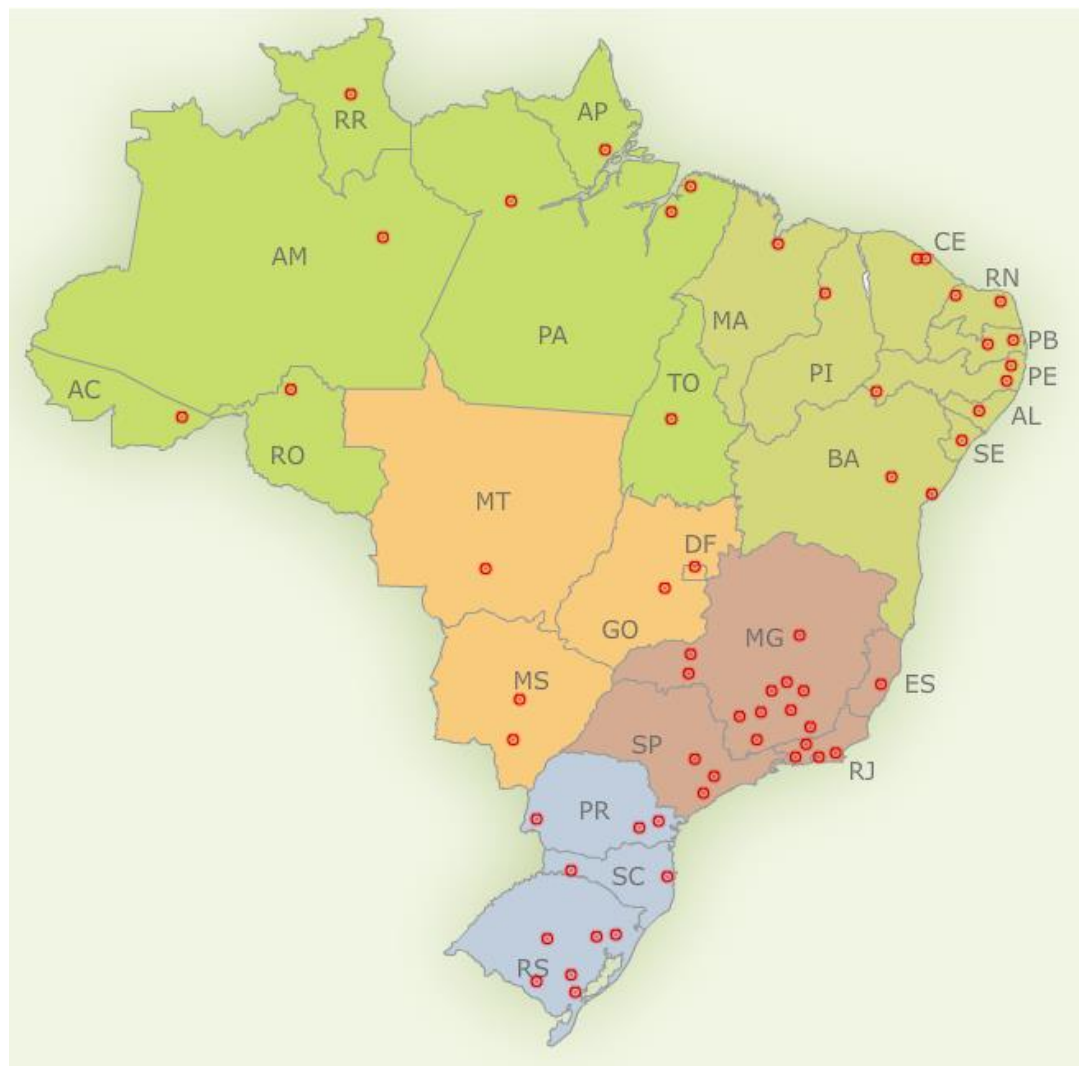

IMAGEM 20 Mapa da rede de expansão de ensino superior.

Fonte http://reuni.mec.gov.br/veja-sua-universidade

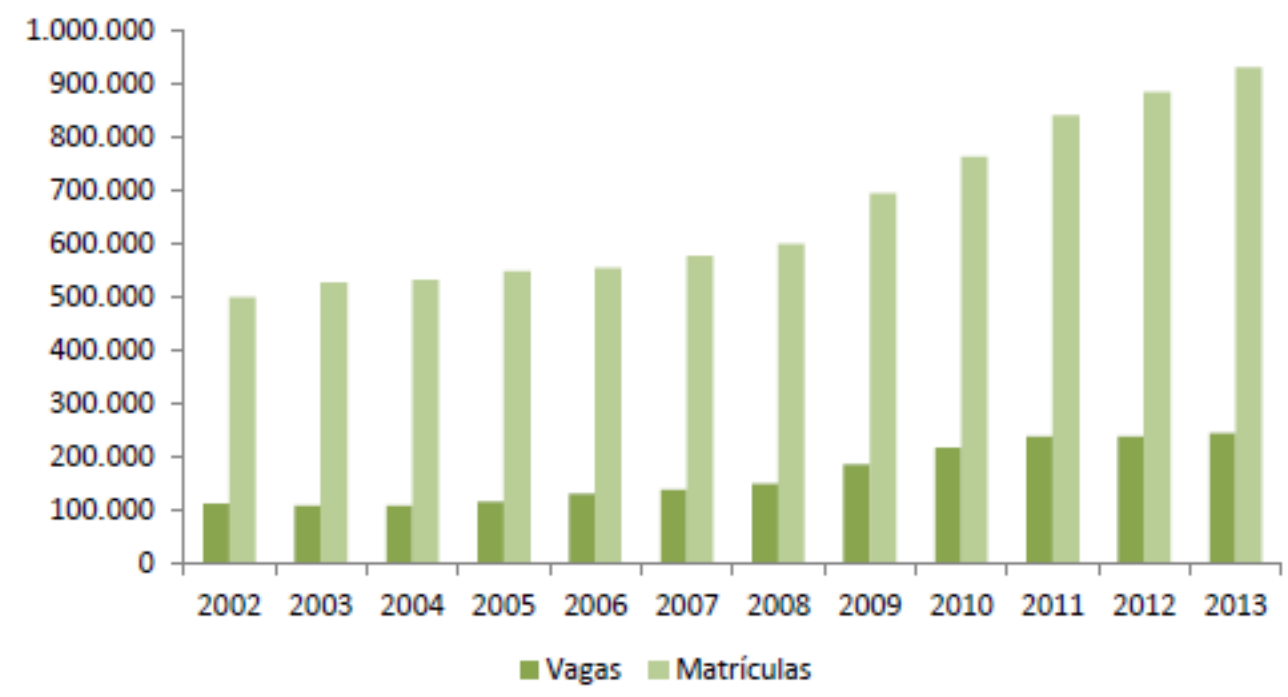

IMAGEM 21 Gráfico do crescimento de vagas e matrículas na graduação nas universidades federais. Fonte: CENSO/INEP

Outro tipo de dado disponibilizado pelo MEC, que interessa particularmente à disciplina de arquitetura e urbanismo, diz respeito ao conjunto de espaços universitários que foram edificados no período. A tabela não explicita quais os critérios foram utilizados para a divulgação dos dados, mas é possível verificar que 30\% da metragem "concluída" diz respeito 
à infraestrutura, o que pode ser razoável considerando que tal item geralmente envolve movimento de terra, rede de água, luz e esgoto. Porém, ao considerar o item Salas de Aula, a informação torna-se confusa, de difícil aferição. Mas a tabela deixa claro quais são os usos considerados pelo MEC para elaborar suas estatísticas.

\begin{tabular}{|c|c|c|}
\hline \multicolumn{3}{|c|}{$\begin{array}{l}\text { Número de obras concluídas em } \mathrm{m}^{2} \text { nas IFES } \\
2003 \text { a } 2013\end{array}$} \\
\hline NOVOS ESPAÇOS & unid & $\mathrm{m}^{2}$ \\
\hline Laboratórios & 368 & $321.055,11$ \\
\hline Salas de aula & 292 & $550.025,41$ \\
\hline Bibliotecas & 43 & $58.414,97$ \\
\hline Restaurantes & 61 & $67.671,35$ \\
\hline Moradias & 33 & $38.174,12$ \\
\hline Espaços administrativos & 182 & $181.552,70$ \\
\hline Áreas multifuncionais & 260 & $770.724,22$ \\
\hline Apoio à comunidade & 67 & $47.231,43$ \\
\hline Áreas esportivas & 43 & $107.050,97$ \\
\hline Auditórios & 27 & $44.169,92$ \\
\hline Infraestrutura & 212 & $879.664,97$ \\
\hline TOTAL & 1.588 & $3.065 .735,17$ \\
\hline
\end{tabular}

Fonte: Balanço Social SeSU - Simec/MEC

Conforme demonstrado pelos dados acima, o programa de expansão, notadamente o REUNI, alicerçado em princípios como a democratização, a inclusão e o incentivo ao ensino, pesquisa e extensão, contribuiu quantitativamente para uma nova realidade da educação superior no país, pela implantação de novas universidades, novos campi universitários e pelo aumento no número de matrículas em todo país.

A equipe do MEC que elaborou o relatório Análise sobre a Expansão das Universidades Federais 2003 a 2012 reconhece, ao final do texto, a necessária continuidade do programa para atingir as metas estabelecidas:

É um marco importante na política educacional brasileira, que precisa ser compreendido como etapa de um processo que deve ser contínuo até que o Brasil atinja a meta de atendimento de matrículas para 33\% de seus jovens de 18 a 24 anos na educação superior, de acordo com o Projeto de Lei do PNE. Todavia, a continuidade do processo de expansão deve estar fortemente alicerçada em referenciais que garantam a qualidade das ações de ensino, pesquisa e extensão das universidades federais brasileiras para que todas se constituam em instituições protagonistas do desenvolvimento do país. ${ }^{21}$ 
Apesar de suas naturais divergências, especialistas em educação de diferentes inclinações doutrinárias concordam num ponto: o sucesso de um projeto educacional depende, basicamente, de políticas de longo prazo conduzidas sem alterações significativas no corpo técnico dos órgãos públicos. O breve relato sobre a educação superior brasileira, no período de 1960 a 2012 apresentado até aqui, mostra a descontinuidade das políticas públicas para educação no país. 


\section{A CRIAÇÃO DA UFABC E SUA IMPLANTAÇÃO}

\subsection{O Projeto Eixo Tamanduatehy}

O município de Santo André passou por um intenso processo de urbanização e industrialização, no final do século XIX, em consequência da implantação da estrada de ferro São Paulo Railway. Grande parte das indústrias implantou-se ao longo da ferrovia com a finalidade de exportação de produtos agrícolas e a importação de manufaturas e bens de capital. Assim, já na primeira metade do século XX, as principais atividades econômicas do $A B C$ paulista ${ }^{22}$ estavam vinculadas territorial e estrategicamente à Ferrovia Santos- Jundiaí ${ }^{23}$ que, na região, estabeleceu-se ao longo da várzea do rio Tamanduateí. Tal condição permitiu o transporte de produtos ao porto de Santos e qualificou o município de Santo André, juntamente com os demais do grande $A B C$, como um dos principais polos industriais brasileiros que, a partir de 1950, torna-se especialmente conhecido por constituir-se um importante polo da indústria automobilística.

A partir do final dos anos 1970, a situação socioeconômica da região do ABC começou a se alterar profundamente com o fim do milagre econômico, com a reorganização da divisão do trabalho e com o fortalecimento do movimento sindical. Houve uma desaceleração do crescimento industrial na região com a saída das indústrias e com a reestruturação produtiva, diminuindo empregos e agravando a recessão nos anos 1980. Tais eventos tiveram grande impacto na ordem social e territorial da cidade. As áreas localizadas na várzea do Rio Tamanduateí e ao longo da ferrovia foram duramente atingidas por este processo. As áreas industriais desativadas se tornaram grandes passivos ambientais, estagnados e desestruturados como potencial urbanístico e produtivo durante muitos anos.

A resposta institucional foi buscar novas saídas para esse quadro de decadência e abandono das grandes glebas. A Prefeitura de Santo André, em 1998 (segundo mandato do prefeito Celso Daniel) ${ }^{24}$, desenvolveu um projeto de renovação urbana para promoção do desenvolvimento econômico da cidade com o chamamento dos principais atores sociais -

\footnotetext{
22 O grande ABC paulista faz parte da região metropolitana de São Paulo e compreende os munícipios de Santo André, São Bernardo do Campo, São Caetano do Sul, Diadema, Mauá, Ribeirão Pires e Rio Grande da Serra.

${ }^{23}$ Em setembro de 1946, a São Paulo Railway foi encampada pelo governo brasileiro em virtude do fim da concessão dada aos ingleses para explorar a rota, tornando-se uma estatal. Em setembro de 1948, o nome da companhia foi alterado para Estrada de Ferro Santos a Jundiaí.

${ }^{24}$ Celso Augusto Daniel iniciou sua carreira política em 1982. Foi um dos fundadores do Partido dos Trabalhadores e prefeito de Santo André por três vezes. Era engenheiro formado pela Escola de Engenharia Mauá, com mestrado em Administração Pública pela Fundação Getúlio Vargas e doutorado em Ciências Políticas pela Pontifícia Universidade Católica de São Paulo. Foi morto em janeiro de 2002.
} 
representantes do setor público, dos sindicatos, do setor empresarial, das organizações e das comunidades locais -, com o objetivo de estimular uma coordenação entre os agentes em prol da requalificação urbana na várzea do rio Tamanduateí e ao longo da ferrovia - o Projeto Eixo Tamanduatehy ${ }^{25}$.

\section{Região Metropolitana de São Paulo}

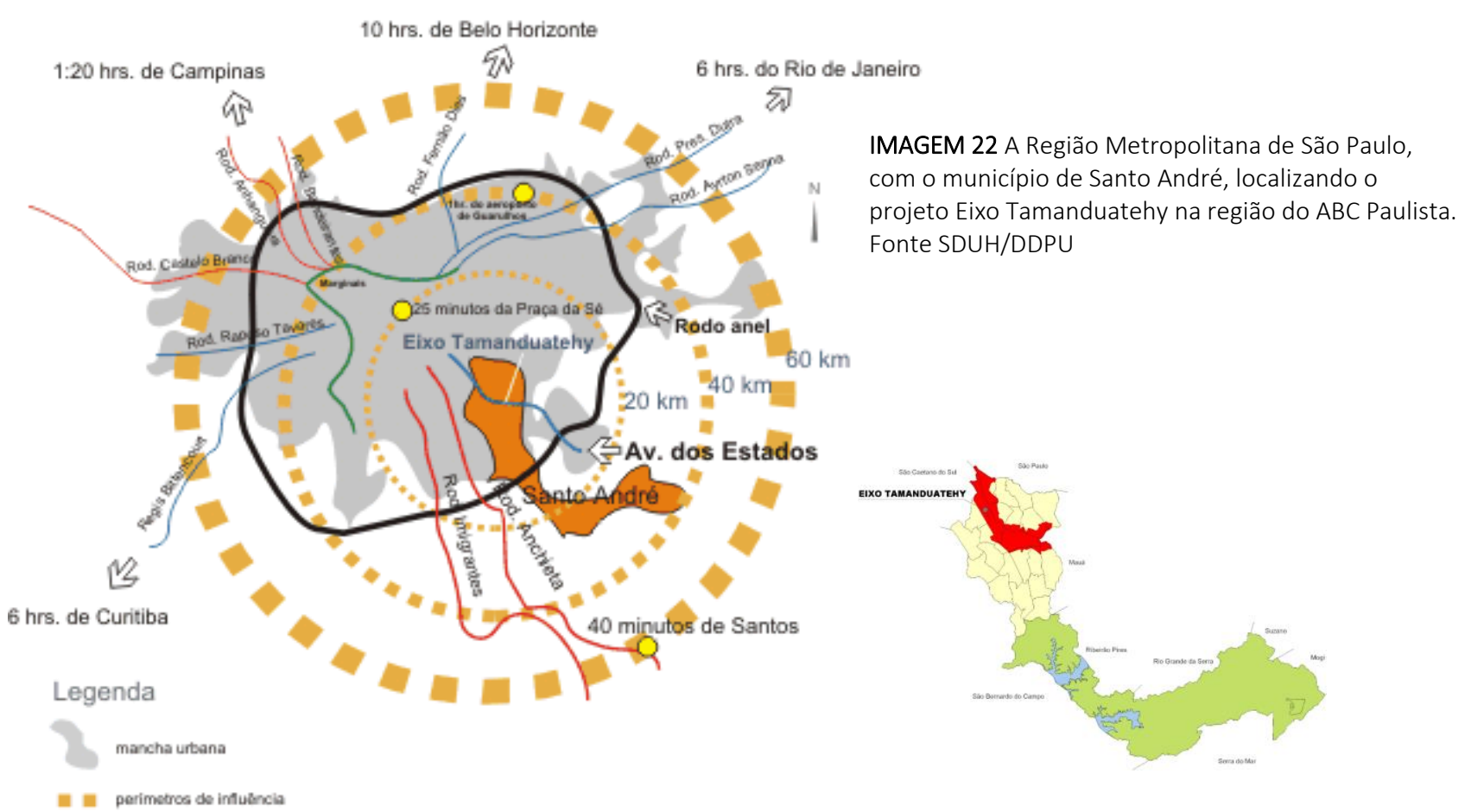

O Projeto Eixo Tamanduatehy estava associado ao Programa "Santo André Cidade Futuro" com estratégias de ação regional e municipal voltadas ao enfrentamento dos efeitos da "globalização". Era necessário recriar o ABC Paulista como uma nova "centralidade", não mais como periferia, quando a região deixaria de ser qualificada como subúrbio por ser uma passagem entre a capital e o porto, para se tornar um lugar, uma cidade, com dinâmica própria ${ }^{26}$.

Era preciso intervir, mesmo reconhecendo que se tratava de questões estruturais relacionadas com a política macroeconômica e que muito pouco poderia fazer o governo municipal. Era necessário implantar políticas públicas para alavancar algum progresso local e para diminuir as fragilidades às variáveis macroeconômicas. ${ }^{27}$ Além disso, problemas como a

\footnotetext{
25 SAKATA, M. N. Projeto Eixo Tamanduatehy : uma nova forma de intervenção urbana em Santo André? Dissertação de Mestrado - Universidade de São Paulo. São Paulo: FAUUSP, 2006.

${ }^{26}$ NEGRELOS, E. P. Novos grandes projetos urbanos na metrópole paulistana. Revista Cidades v.9, n. 16, 32, 2012.

${ }^{27} \mathrm{Cf}$. Folder de divulgação do projeto:

PREFEITURA MUNICIPAL DE SANTO ANDRÉ. O futuro já chegou - Eixo Tamanduatehy. Santo André, 1998.
} 


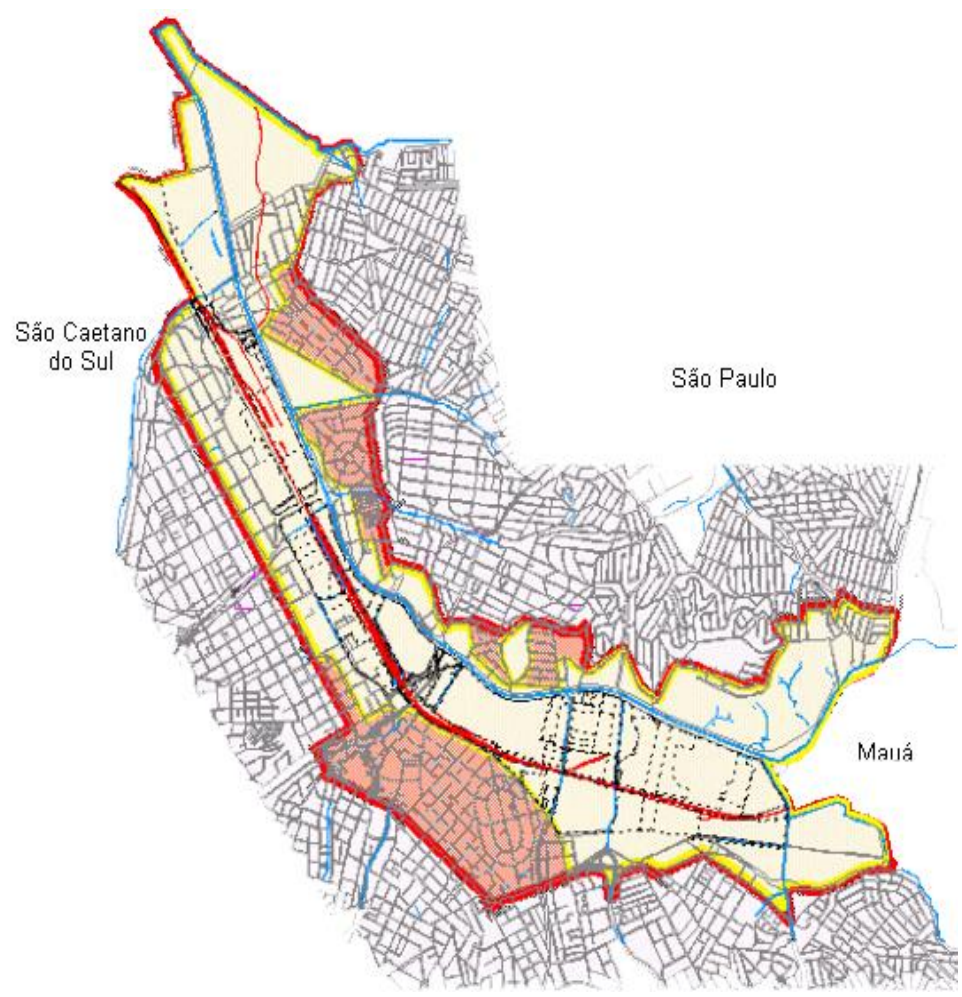

IMAGEM 23 Perímetro do projeto Eixo Tamanduatehy. Fonte SDUH/DDPU contaminação do solo e a poluição do rio indicavam a necessidade de recuperar o meio ambiente. Para tanto, a prefeitura de Santo André mobilizou sua equipe técnica na busca de novas práticas de requalificação e revitalização urbanística e ambiental em outros países.

A concepção urbanística do projeto se baseia na existência de um eixo linear, com área de 12,8 km² e 10,5 km de extensão, conformado pelo Tamanduateí e pelo sistema de transporte, composto pela antiga ferrovia Santos-Jundiaí e pela Avenida dos Estados.

Tem-se, dessa forma, a utilização do conceito clássico de "eixo urbano", entendido como modo principal de organização do crescimento da cidade, geralmente representado por uma grande avenida, servindo para desencadear processos de transformação.

Como ponto de partida para a construção do projeto, definiu-se pela contratação de quatro equipes de projetistas, incluindo a participação de arquitetos internacionais. A Europa, nos anos 1990, vivenciava experiências de reaproveitamento de grandes espaços resultantes da desativação de áreas portuárias, ferroviárias e industriais, levando-as de pontos fracos da malha urbana a locais transformados em ícones urbanos, em função da renovação dessas regiões da cidade. Tal modelo de planejamento, que teve a cidade de Barcelona como referência, foi exportado para a América Latina: Chile, Argentina e Brasil. Essa concepção tinha em seu bojo a cidade como mercadoria e reforçava a importância do marketing regional para vender sua imagem (ARANTES, VAINER, \& MARICATO, 2000, p. 51). 
A primeira fase do projeto - de definições urbanísticas e estudos preliminares - foi conduzida pela urbanista brasileira Raquel Rolnik ${ }^{28}$ e pelo urbanista espanhol Jordi Borja ${ }^{29}$, ambos consultores do Projeto Eixo Tamanduatehy que determinaram as diretrizes:

- Coexistência territorial dos usos;

- Combinação do porte dos empreendimentos;

- Combinação dos níveis de renda (inclusão social);

- Estímulo dos fluxos urbanos;

- Mosaico de áreas verdes / passeios públicos;

- Estruturação dos tecidos urbanos;

Com as diretrizes definidas, foram contratados os urbanistas Joan Busquets, Eduardo Leira, Christian de Portzamparc e Candido Malta. Cada qual coordenou sua própria equipe, e as quatro equipes trabalharam na intervenção da mesma área, porém com abordagens diferentes e complementares:

\section{Equipe 1: Eduardo Leira (Espanha)}

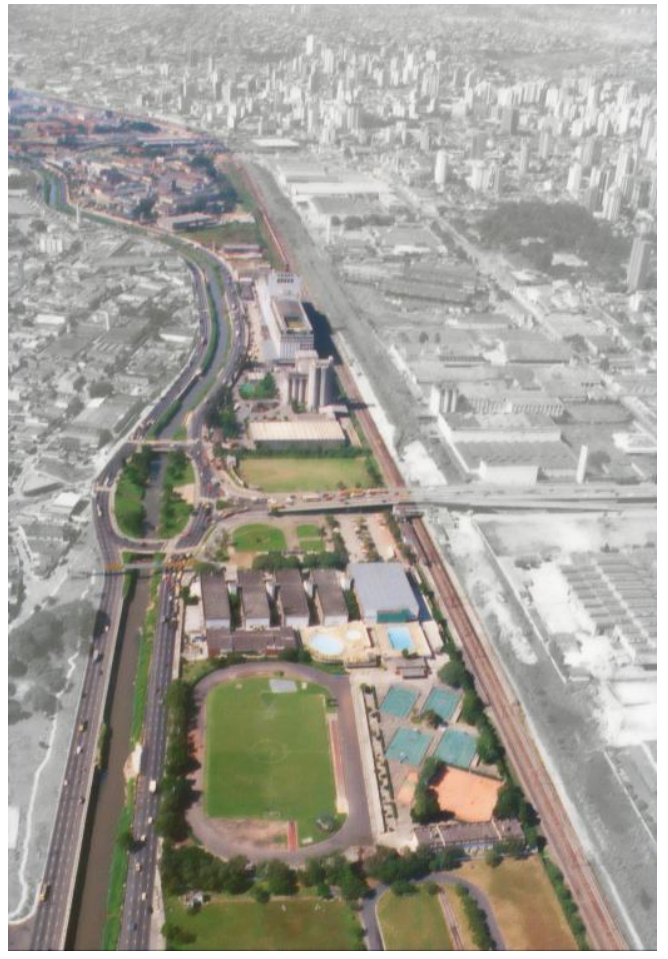

IMAGEM 24 Vista aérea do Eixo Tamanduatehy. Fonte: DDPU
Tema abordado: mobilidade, acessibilidade e o direito de circular.

Objetivo: Conexão inter-regional. Ampliar a relação da região com a metrópole, articulando vetores de circulação, acessibilidade.

Equipe: Eduardo Leira, Susana Jelen; Nuno Portas e Manuel Herce (colaboradores); Jorge Bonfim, Francisco Prado, Luciano Fiaschi.

A proposta de Leira comprovou a posição estratégica de Santo André em relação à região metropolitana de São Paulo, identificando nas ligações urbanas o grande potencial do Eixo Tamanduatehy. A proposta criou a Diagonal ABC, uma via de $25 \mathrm{~km}$ ligando as rodovias Imigrantes e

\footnotetext{
28 Raquel Rolnik, secretária de Planejamento do município de São Paulo no período 1989-1992, já havia contratado Borja como consultor para sua Secretaria e desenvolveram conjuntamente projetos para aquela cidade.

${ }^{29}$ Geógrafo urbanista catalão, é um dos principais pensadores do urbanismo europeu. Atuou em projetos urbanísticos de Barcelona para as Olimpíadas de 92 e em outros projetos de recuperação de centros históricos. Autor do livro Local e Global, juntamente com Manuel Castells.
} 
Anchieta ao Complexo Jacu-Pêssego, na zona leste de São Paulo, e dali ao aeroporto de Cumbica. O trem seria incorporado amigavelmente ao tecido urbano, transformando-se numa espécie de metrô de superfície. A equipe propôs a instalação de um polo de serviços capaz de criar uma nova centralidade metropolitana a partir de uma nova estação de trem. Conforme imagens 25 e26.

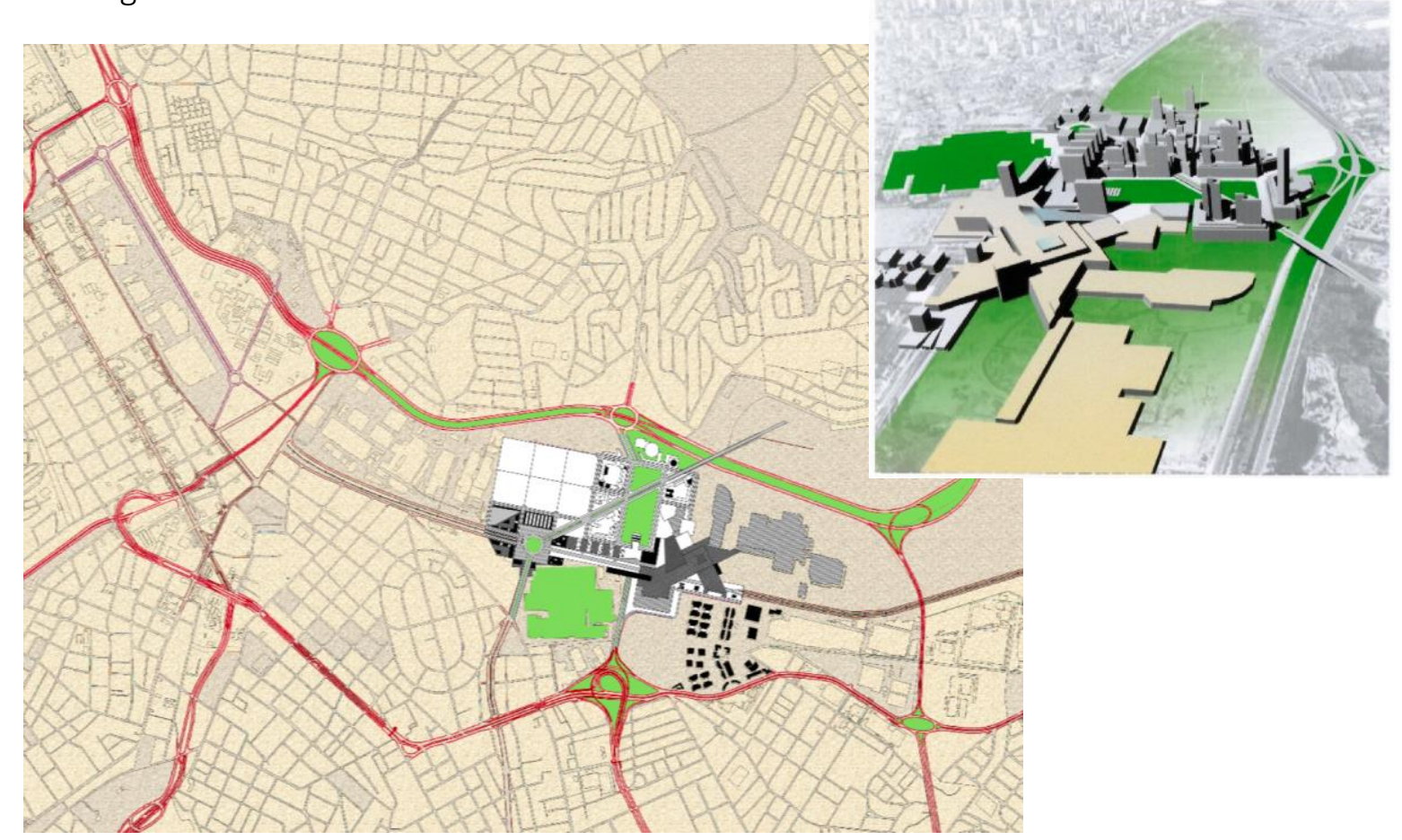

IMAGEM 25 Proposta de Eduardo Leira para nova centralidade a partir de nova estação ferroviária. Fonte: DDPU

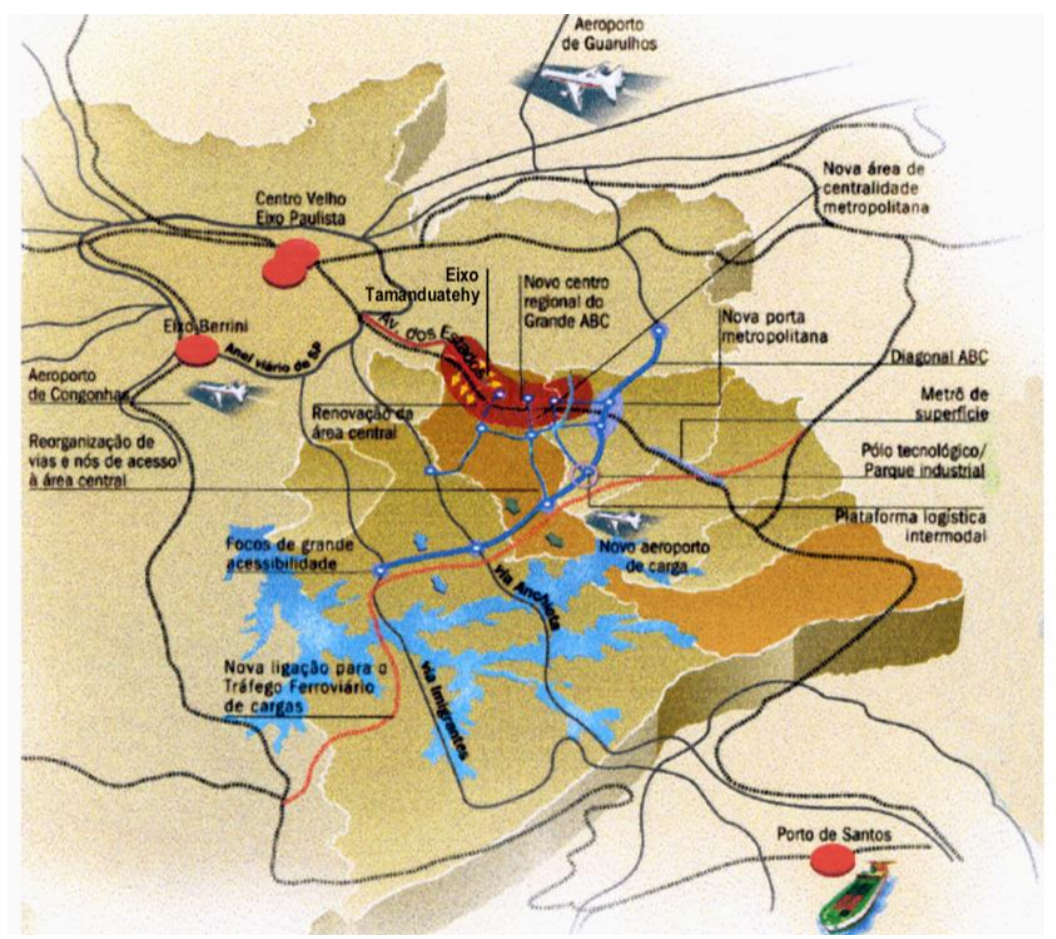

IMAGEM 26 Proposta de ligação inter-regional.

Fonte: DDPU 


\section{Equipe 2: Joan Busquets (Espanha)}

Tema abordado: Espaços públicos e parques lineares.

Objetivo: Focalizou a recuperação ambiental por meio da criação e ampliação de áreas verdes e parques, propondo articulações entre a Avenida dos Estados, a ferrovia e o rio.

Equipe: Jorge Wilheim, José Francisco Xavier Magalhães, José Magalhães Jr., Maristela Faccioli, Luciana Machado e Hector Vigliecca.

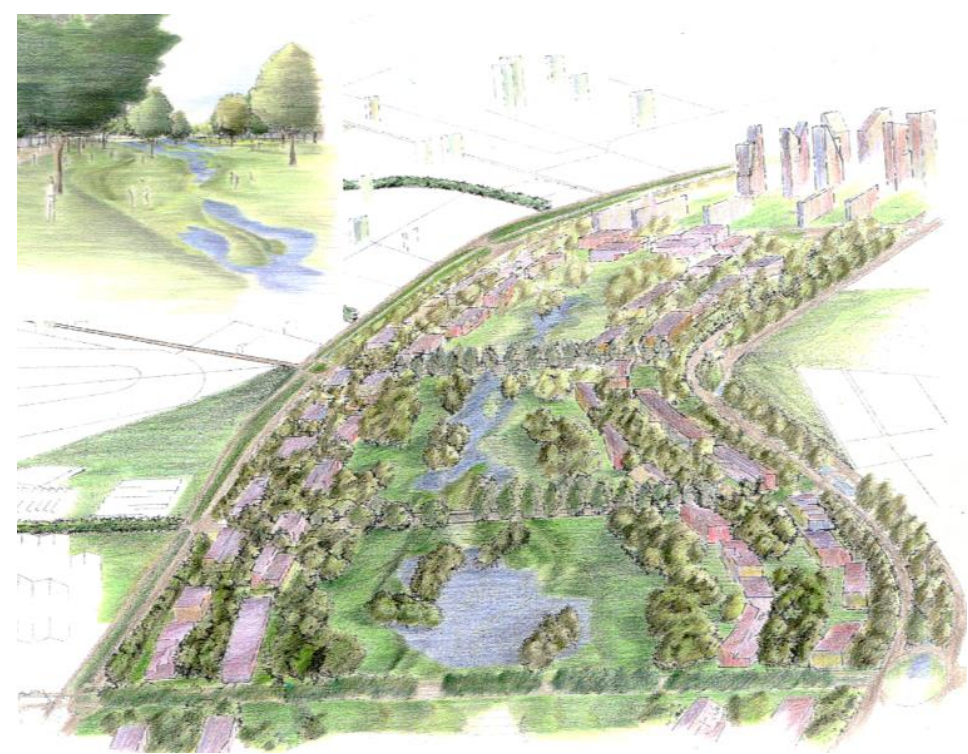

IMAGEM 27 Desenho elaborado pela equipe de Busquets, transformando as margens do rio Tamanduateí em um grande parque. Fonte DDPU

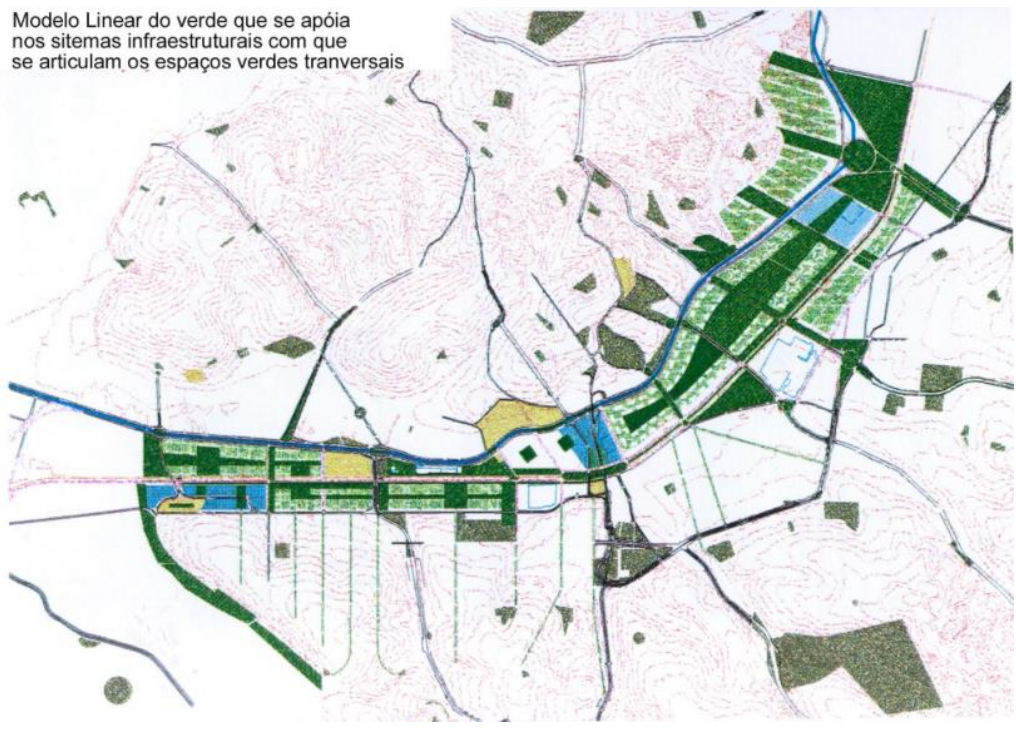

Usando como referência as urbanizações realizadas em cidades como Roterdã, Buenos Aires e Barcelona, a equipe dirigida por Busquets propôs o aproveitamento das águas do rio, a partir da despoluição, como o elemento central de uma ampla área verde capaz de dar uma identidade à cidade de Santo André.

Ao longo do parque de 10 km, núcleos de edifícios poderiam concentrar escritórios, áreas de serviços, lazer e cultura. O eixo viário (trem e avenida) seria valorizado pelo prolongamento do metrô paulistano e incorporado à área verde.

IMAGEM 28 Parque Linear proposto por Busquets Fonte: SDUH/DDPU 


\section{Equipe 3: Christian de Portzamparc (Espanha)}

Tema abordado: Quadras abertas e volumetrias.

Objetivo: Desenhos das quadras e suas volumetrias, possibilitando maior permeabilidade.

Equipe: Francois Barberot, Jaques Suchodolski e Pierre Emanuel; Bruno Padovano, Dora Cerruti, José Paulo de Bem, Otávio Leonídio Ribeiro, Roberto Righi e Suzana Jardim.

Ao abordar a relação entre o indivíduo e a arquitetura, a equipe coordenada pelo arquiteto francês propôs que os terrenos da região fossem loteados conforme regras especiais, que liberariam pequenas praças internas, abertas ao pedestre. Trabalhando volumes verticais e horizontais. $\mathrm{O}$ conceito da quadra aberta criaria novas possibilidades de insolação e conforto acústico para os bairros que se formariam ao longo da avenida dos Estados.

\section{UM MÉTODO}

UM INSTRUMENTO COMERCIAL

Os terrenos estão lá. Este projeto quer ser para a municipalidade um instrumento metodológico para valorizar o território; um instrumento para que a municipalidade não se contente em vender metros quadrados de terreno, mas que a habilite a propor aos investidores, grandes ou pequenos, a possibilidade de uma organização, de uma qualidade de vida urbana. Se enganam todos aqueles que pensam tratar-se isto de um luxo supérfluo: trata-se, em verdade, de uma aposta crucial da civilização nos dias de hoje, em qualquer lugar do mundo.

Não se pode depender passivamente da oferta de investimentos. É preciso, ao contrário, mudar o tipo de oferta, através de um projeto fundado na qualidade, e que se adapte ao mercado. Fazer urbanismo significa, também, gerar riqueza; um projeto de urbanismo deve ser, também, um instrumento comercial $^{30}$.
IMAGEM 29 Croquis de Christian de Portzamparc demonstrando a eficiência da quadra aberta. Fonte SDUH/DDPU

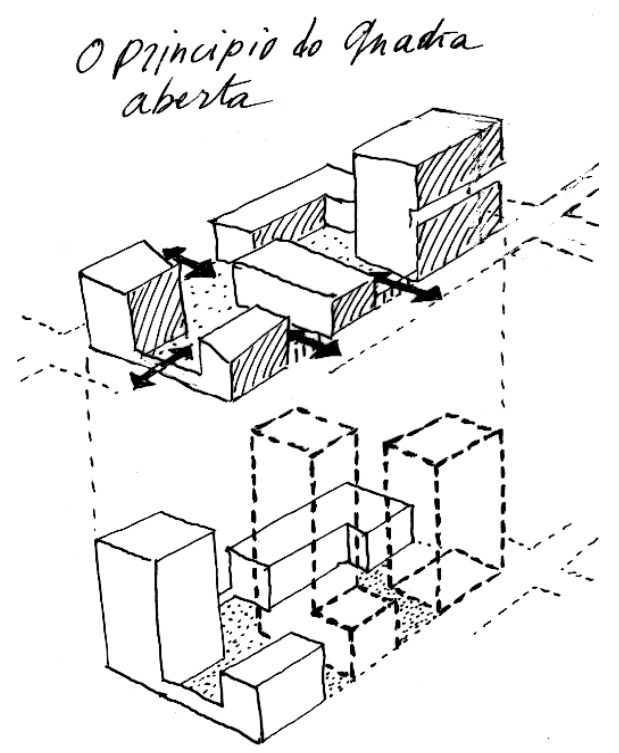

Mais rista

e mais luz
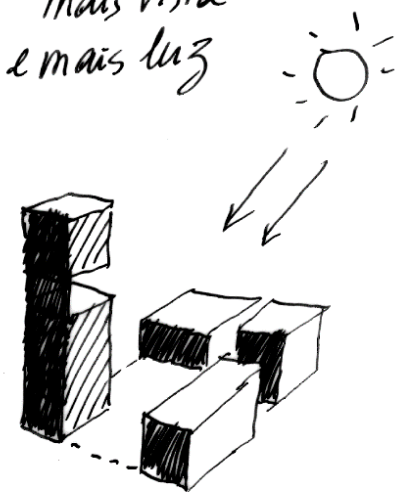

vertical t horijontal

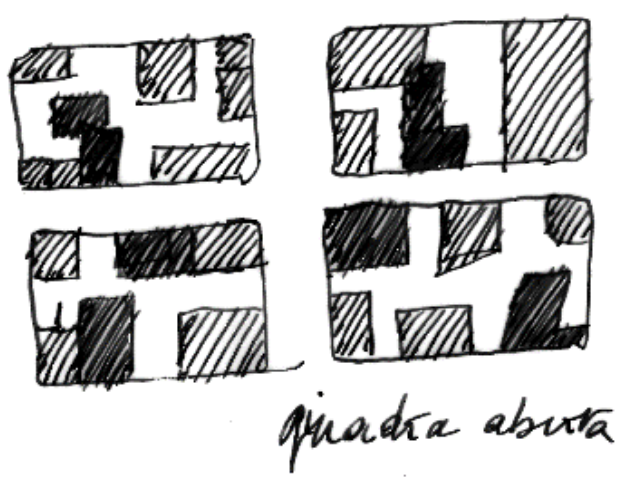

${ }^{30}$ Cf. PREFEITURA MUNICIPAL DE SANTO ANDRÉ. Projeto Tamanduatehy. Santo André, 1999. 

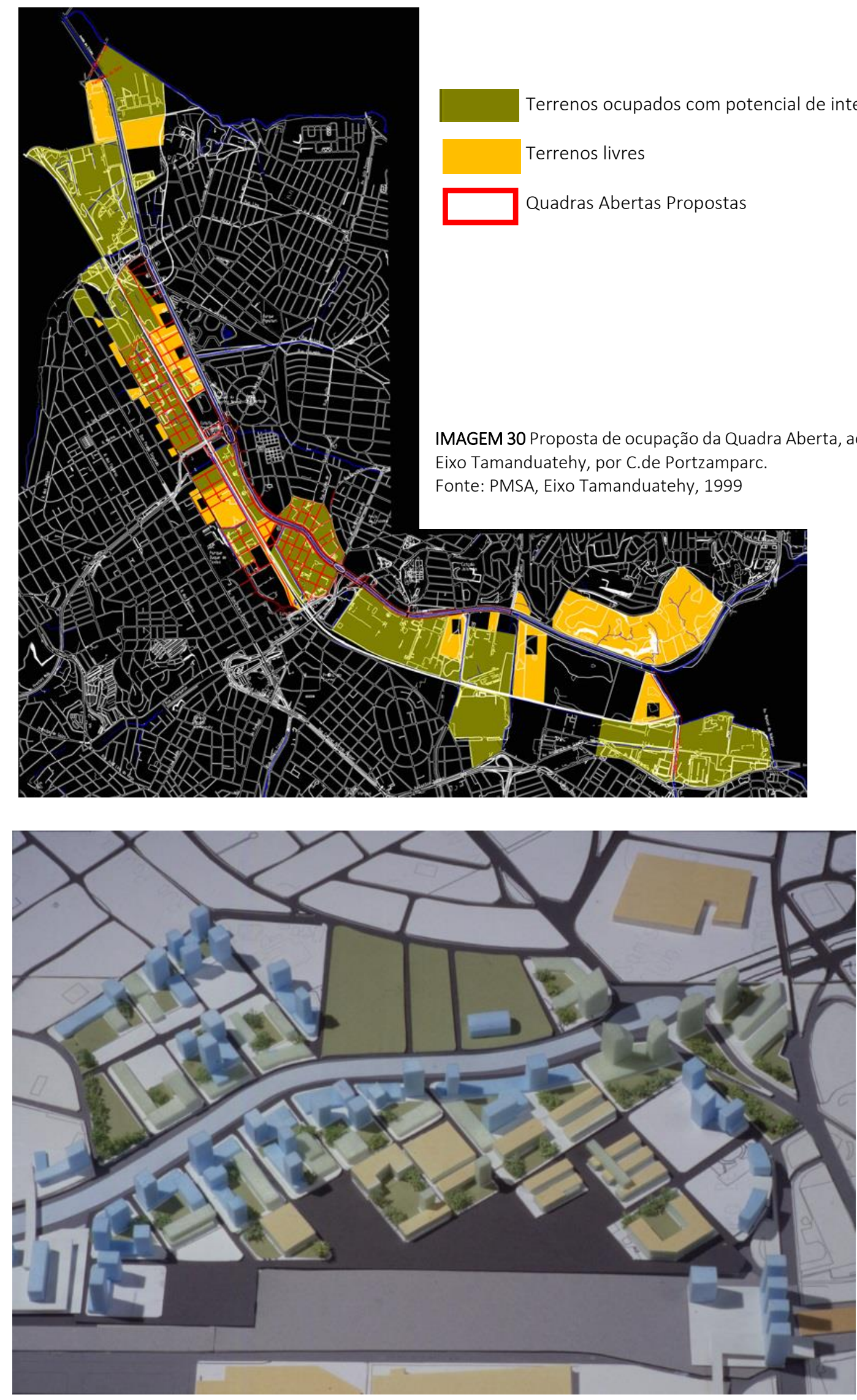

IMAGEM 31 Maquete da ocupação proposta por C. de Portzamparc na área da Rhodia e da UFABC, atualmente.

Fonte: PMSA, Eixo Tamanduatehy, 1999 


\section{Equipe 4: Candido Malta (Brasil)}

Tema abordado: Diagnóstico urbanístico e novas centralidades

Objetivo: Criação de novos empreendimentos e definição de um novo desenho constituindo um polo para a região metropolitana, elevando a cidade de Santo André como nova centralidade na metrópole policêntrica de São Paulo.

Equipe: Cláudia Bitran, Luciane Shoyama, Luiz Carlos Costa, Priscila Izar, Vera Santana Luz e Viviane Lanfranchi Vaz

Com altas torres de escritórios e longos edifícios, a proposta de Cândido Malta tem a ousadia de criar objetos arquitetônicos como articuladores do lugar: edifícios-ponte, cruzando a avenida e a ferrovia, prédios de até 500 m de altura e áreas de lazer, como uma praia urbana, utilizando o futuro rio despoluído. Das propostas, sugere-se como a mais completa, fechada em si mesma, e por isso menos complementar às demais proposições. Pode ser vista como um exercício das possibilidades futuras, caso a urbanização do Eixo Tamanduatehy realmente se consolide.

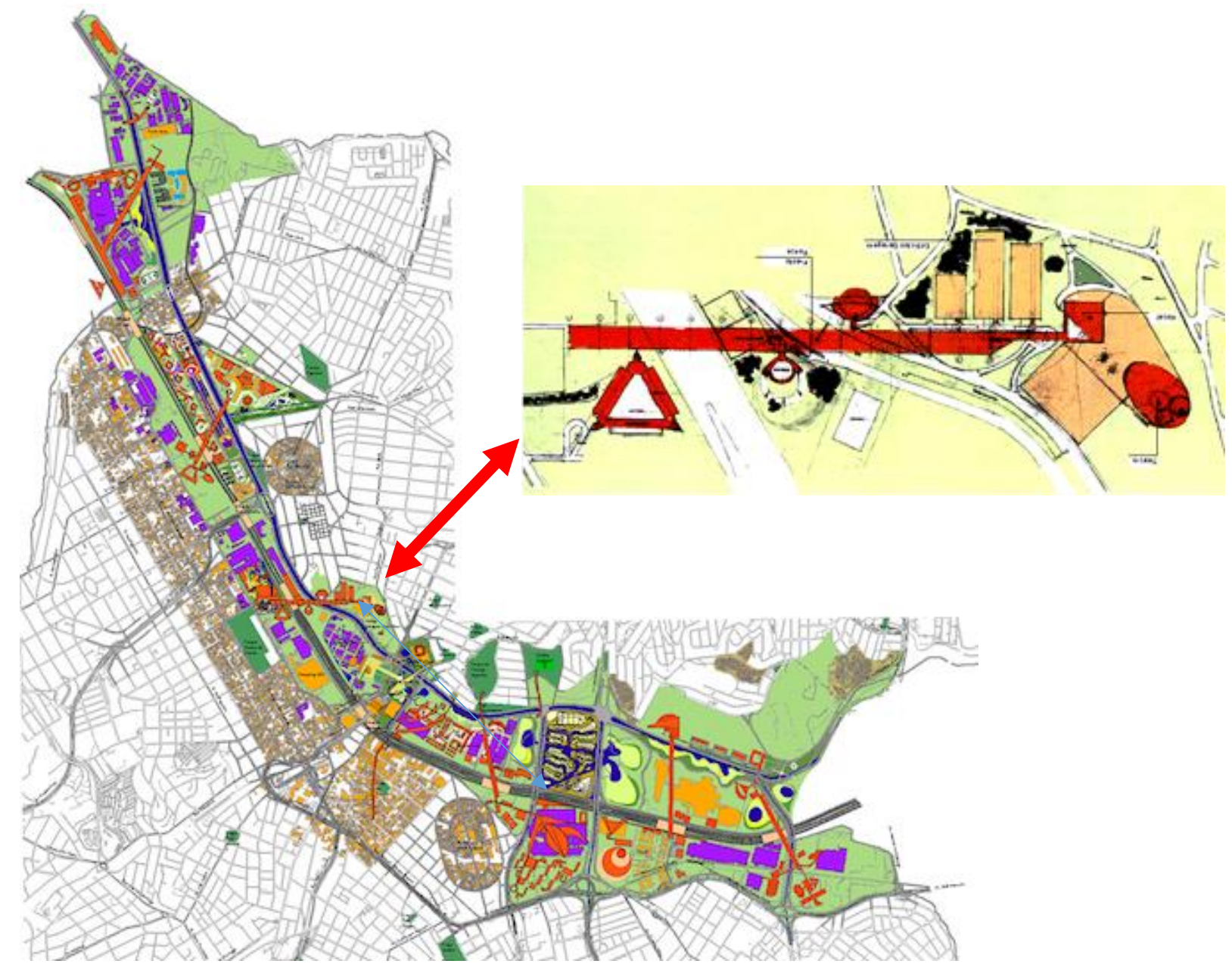

IMAGEM 32 Proposta Candido Malta para novas centralidades e, no detalhe, proposta para Centro de Convenções na área onde se situa a UFABC hoje.

Fonte: SDUH/DDPU 
Os estudos e anteprojetos das quatro equipes foram expostos em abril de 1999, em evento no Moinho São Jorge, uma das históricas fábricas localizada no Eixo Tamanduateí, com grande visibilidade. Em seguida, houve uma expressiva divulgação de alcance nacional: os projetos foram expostos no MASP e, para garantir o caráter metropolitano do projeto e atrair investidores do mercado imobiliário, foram expostos em universidades (USP, Mackenzie, PUC, etc.), sendo ainda apresentados na IV Bienal de Arquitetura de São Paulo, no final de 1999, como projeto-modelo de requalificação urbana. ${ }^{31}$

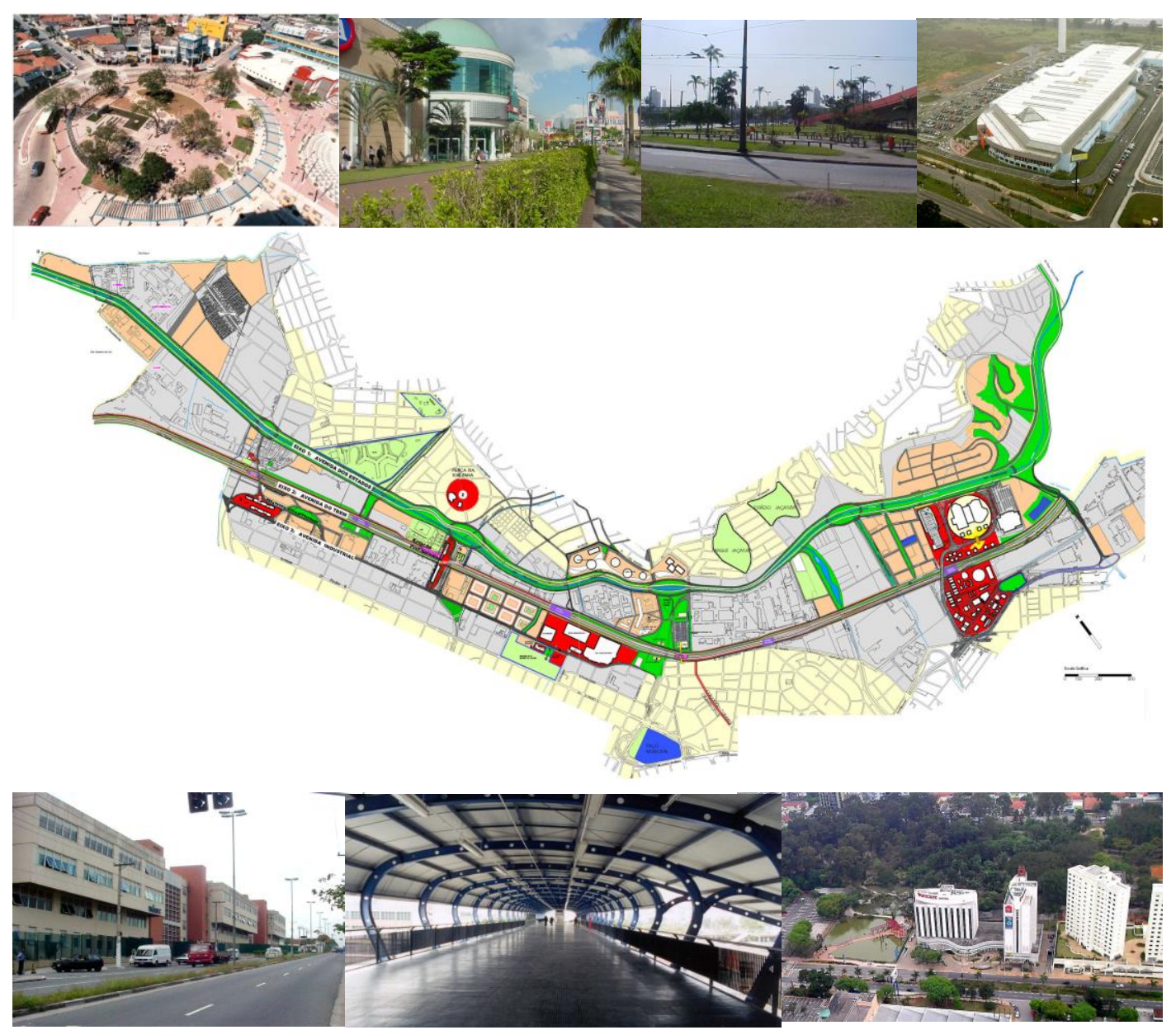

IMAGEM 33 Empreendimentos realizados do Eixo Tamanduatehy, no período de 2000-2007. Fonte SDUH/DDPU, 2007

A segunda fase do Eixo Tamanduatehy, a partir de 2002, é a continuidade e aplicabilidade do projeto, agora sem os consultores nacionais e internacionais e passando a ser gerido no âmbito da Secretaria de Desenvolvimento Urbano (SDU) da Prefeitura de Santo André. O projeto recebeu duras críticas de intelectuais como Otília Arantes e Ermínia Maricato, por tentar implantar um modelo catalão de planejamento estratégico em uma realidade tão

\footnotetext{
${ }^{31}$ Publicado na Folha de São Paulo em 13/04/1999
} 
distinta - um município com graves problemas de déficit habitacional -, o que poderia levar a uma gentrificação, como aconteceu em outras cidades latinas e brasileiras onde o modelo foi implantado.

Segundo Teixeira, o projeto conseguiu iniciar, até certo ponto, um processo de recuperação da degradação física com a reconversão de usos das áreas subutilizadas, por meio de algumas operações urbanas e um novo plano diretor, que estabelecia novos instrumentos de captação de recursos para intervenções na própria área do Eixo. Deparou-se, porém, com uma total dependência do mercado imobiliário para poder efetivar as diretrizes colocadas, dado que grande parte das intervenções seriam realizadas em solo de propriedade privada, comprometendo sua viabilidade.

Dessa forma, os "novos" espaços públicos urbanísticos implantados no perímetro do Eixo, resultaram no "emolduramento" dos megaempreendimentos comerciais implantados, sem transformarem-se em elementos de "inclusão social", por não haverem sido apropriados pela população local, a qual não os utiliza.[...] em suma, podemos afirmar que o projeto "Eixo Tamanduatehy" acabou por se adequar à lógica do capital privado, sendo incapaz de se traduzir em mecanismo de redistribuição de renda e poder, ou seja, de se materializar em um projeto de construção de uma esfera pública, destoando, dessa forma, da "dimensão pública" instituída em Santo André nas gestões petistas analisadas (1997/2000 e 2001/2004). Ao final, vale ressaltar que um projeto deste porte deveria atuar, não só no sentido de alavancar atividades econômicas, mas também de possibilitar a apropriação do mesmo por toda a sociedade, particularmente através de projetos habitacionais e de espaço público, a partir da existência de mecanismos públicos visando uma equação mais equilibrada entre desenvolvimento econômico e desenvolvimento social. Nesse sentido, deveria caber ao poder público, a implementação e o controle das operações urbanas e parcerias, mediante um projeto de desenvolvimento para a região, com a definição prévia de atividades a serem induzidas, contemplando, além dos investimentos imobiliários e infraestruturais (principalmente o transporte), outros aspectos associados ao desenvolvimento social de toda a cidade, como habitação popular, cultura, lazer e educação. (TEIXEIRA, 2010)

A Prefeitura de Santo André mantinha um certo estoque de áreas públicas dentro do projeto do Eixo Tamanduatehy e, em 2003, em um cenário político federal favorável, empenhou-se em nova empreitada para fazer valer os pressupostos projeto. 


\subsection{A Implantação da UFABC: Campus Santo André}

Com o Plano de Expansão da Universidades Federais, conforme visto no subcapitulo 1.4, o Ministério da Educação e a Prefeitura de Santo André somaram esforços para viabilizar a UFABC. A universidade daria um novo significado aos preceitos sociais do amornado Projeto Eixo Tamanduatehy, como um equipamento público capaz de viabilizar a inclusão social e

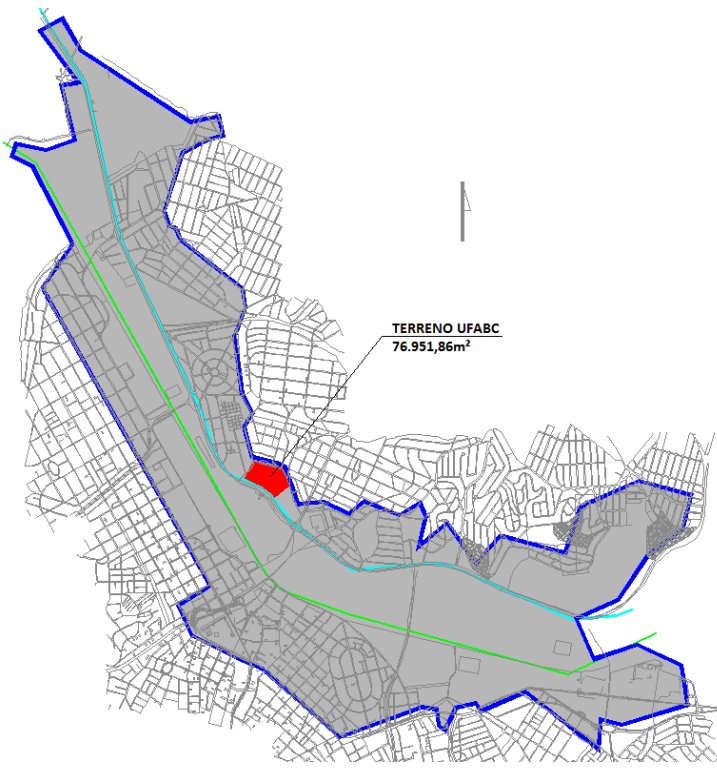

IMAGEM 34 Localização da área da UFABC - Campus Santo André, no Eixo Tamanduatehy. Fonte: Acervo pessoal requalificar o espaço urbano. A UFABC foi uma prioridade do governo federal e local, configurando-se como uma nova âncora urbanística, acompanhada de uma política de promoção do governo federal, regional e local.

A interlocução com o MEC, em nível municipal, ficou sob a responsabilidade da Secretaria de Desenvolvimento Urbano e Habitacional - SDUH na figura da arquiteta urbanista Rosana Denaldi. A primeira contrapartida do município foi a doação de uma área de 76.951,86 m², localizada em um espaço de importante confluência modal de

transporte, no Eixo Tamanduatehy (também de responsabilidade da SDUH), autorizada pela Lei Municipal no 8.748, de 15 de setembro de 2005 .

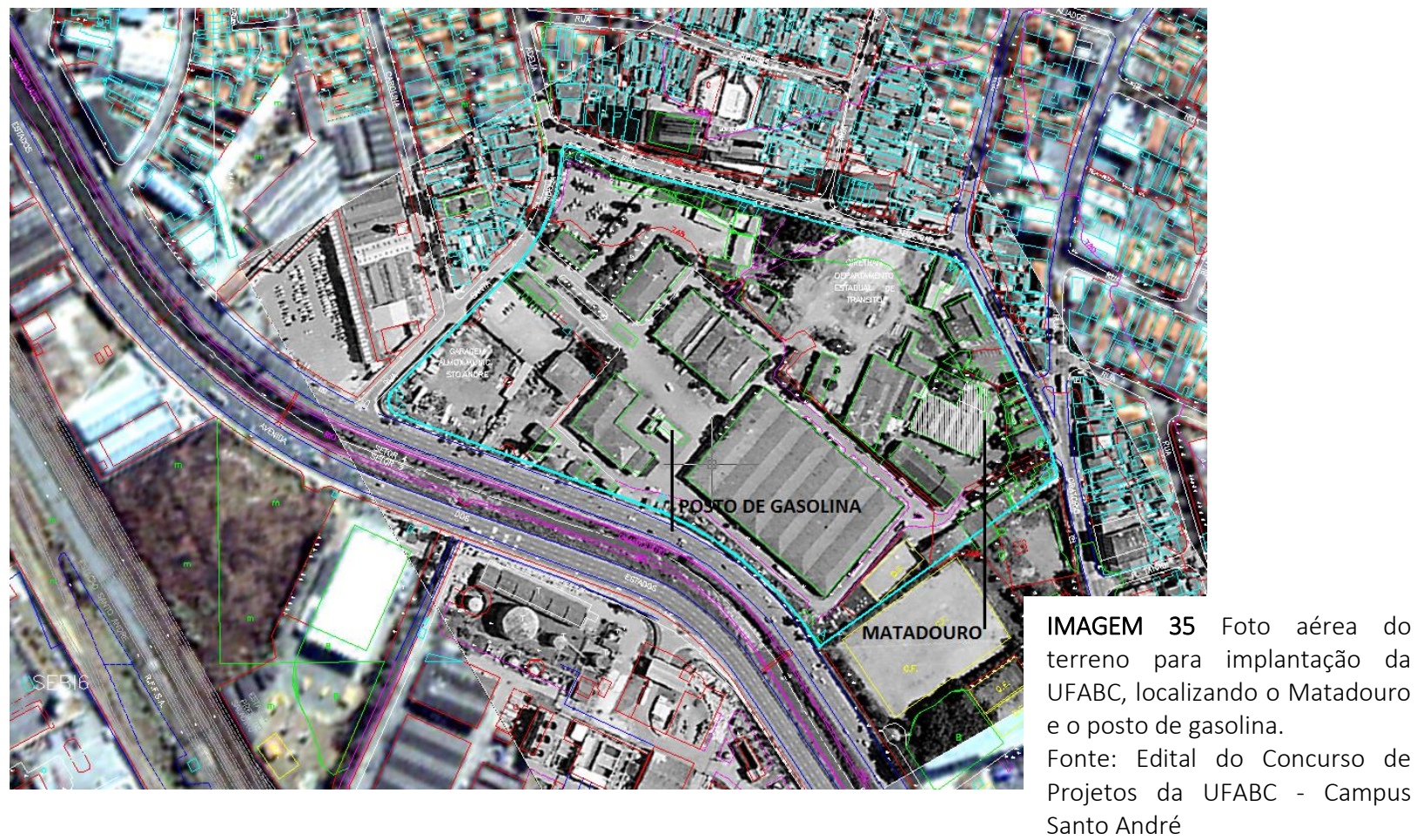




\section{3. Área para a implantação da Universidade}

O laudo de avaliação do terreno ${ }^{32}$ estimou seu custo em $\mathrm{R} \$ 11.665 .718,48$, conforme Fator Monetário Padrão do Município em 2005. O valor corrigido para a atualidade é de R\$ 21.861.632,40 (valor exercício 2016).

O terreno doado era o canteiro da Secretaria de Obras da Prefeitura de Santo André, onde já havia diversos edifícios consolidados, com aproximadamente $25.000 \mathrm{~m}^{2}$ de área construída, como as oficinas de manutenção de veículos, a garagem, as oficinas de carpintaria, hidráulica, elétrica etc.

Dentre os edifícios consolidados no terreno, vale destacar a presença de uma construção histórica, o Matadouro Municipal, inaugurado em 1914, como um "Matadouro Modelo com capacidade para abater sessenta bovinos e cem ovinos, lanígeros ou ovinos (...)", conforme relata a historiadora Suzana Kleeb (2005), da Secretaria de Cultura de Santo André. O valor histórico do edifício está associado a um período no qual o saneamento e a higienização passaram a ser uma preocupação pública, pois as instalações seriam ladrilhadas e asfaltadas de acordo com as exigências higiênicas modernas, além de remeterem à colonização italiana que se deu na região. A esse respeito, vale ainda destacar que o Matadouro foi administrado por uma importante família da região, a família de Luiz Martinelli.

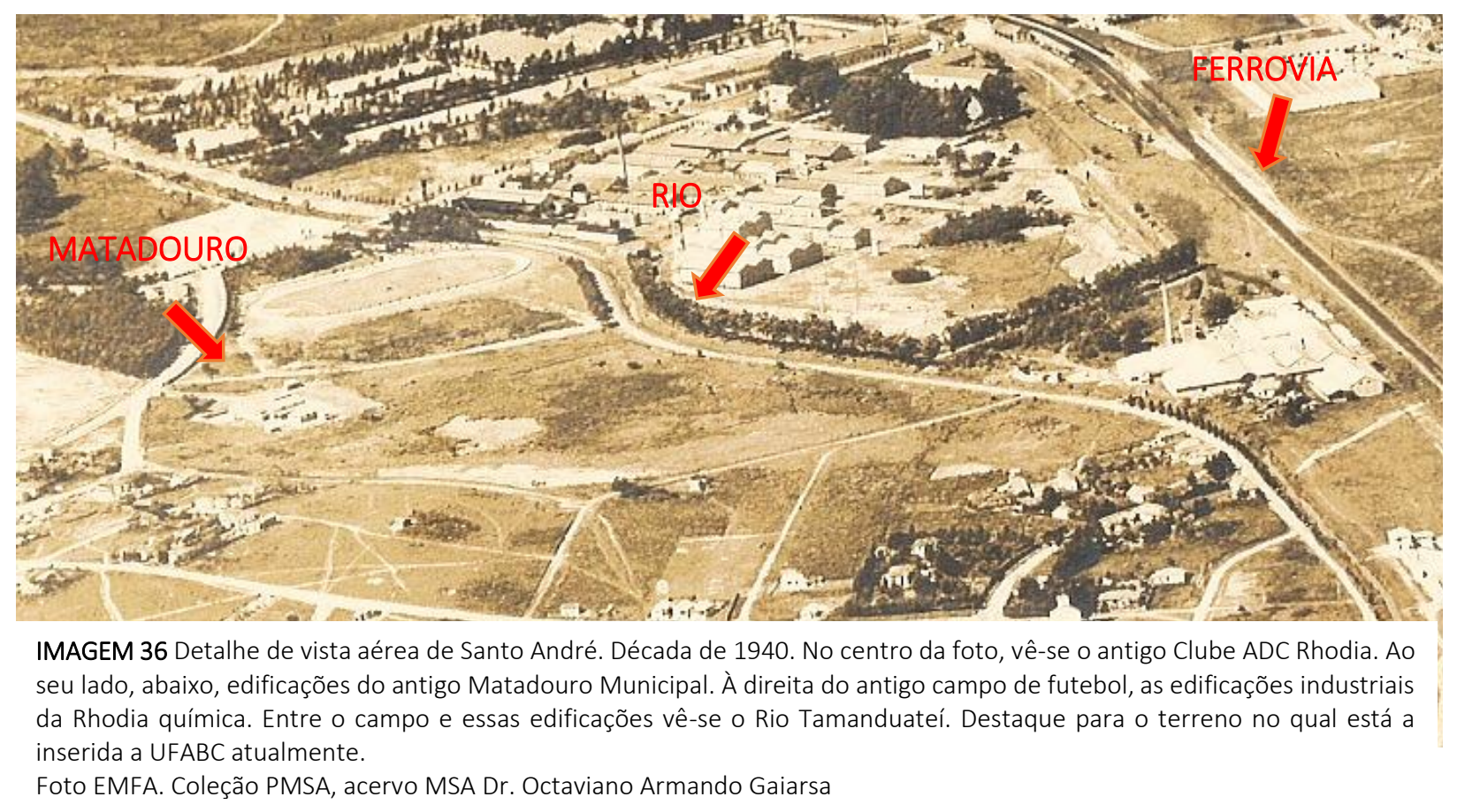

${ }^{32}$ Cf. Anexo A - Doação Terreno Santo André. 
O antigo matadouro, de telhado em lanternim na linha de cumeeira, em estrutura de madeira, que permite iluminação e circulação de ar, foi preservado por ser objeto de intervenção no concurso para os projetos arquitetônicos da UFABC, assunto que será tratado adiante. Com exceção do matadouro, todos os outros imóveis foram demolidos no terreno para dar espaço à Universidade. A existência de um posto de gasolina, que abastecia a frota municipal (75.000 litros de combustível entre 1969 e 2002), foi motivo de mitigação de passivo ambiental durante a implantação da universidade.

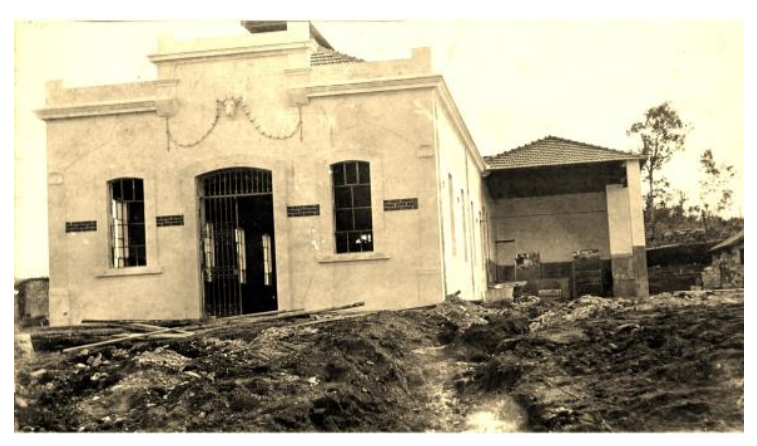

IMAGEM 37 Matadouro Municipal em 1915.

Foto: Coleção PMSA, acervo MSA Dr. Octaviano Armando Gaiarsa

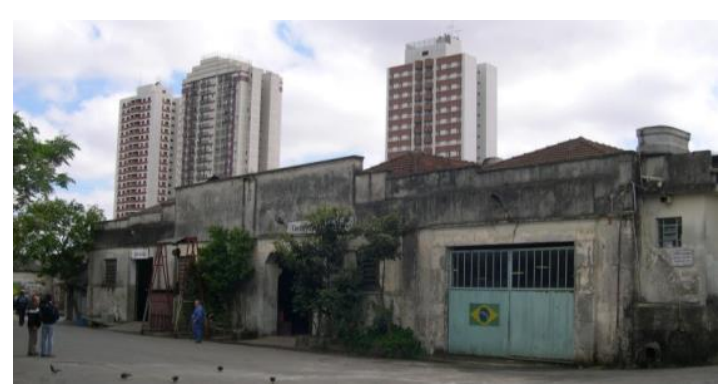

IMAGEM 38 Vista do antigo Matadouro, ocupado por oficinas da PMSA em 2005. Foto: Suzana Kleeb, 2005

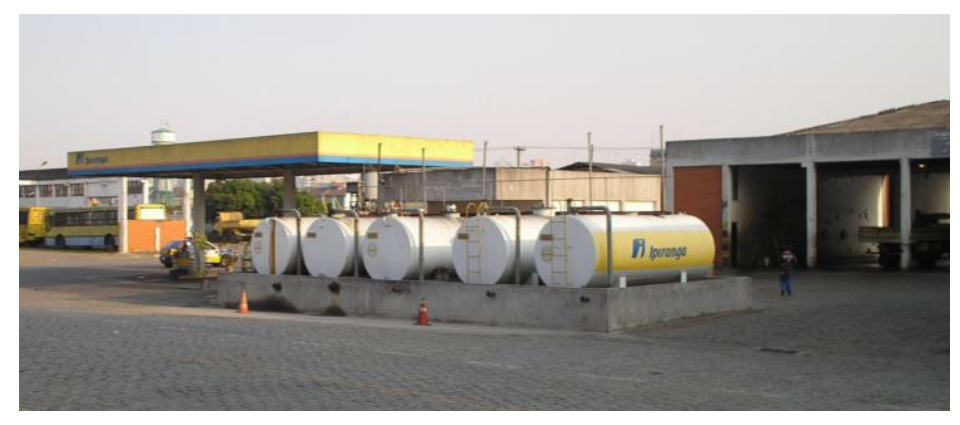

IMAGEM 39 Posto de Combustível Foto: DDPU, 2005

\subsection{A Lei de Criação da UFABC}

Após a eleição do presidente Luiz Inácio Lula da Silva, houve um grande movimento das prefeituras da região e segmentos da sociedade civil, que se manifestaram por meio da Câmara do $\mathrm{ABC}^{33}$ em audiências públicas, debates, atos públicos, recolhimento de assinaturas, resultando em um documento que subsidiou o Ministro da Educação, Tarso Genro, e do Planejamento, Guido Mantega, a estruturar o projeto de lei que deu contornos efetivos à criação da Universidade Federal do ABC (OLIVEIRA, 2010) e que, em futuro próximo, subsidiaria

${ }^{33}$ A Câmara do ABC é uma instancia regional que reúne representantes do governo estadual, municipal e sociedade civil para debater as ações necessárias para o desenvolvimento regional. 
a documentação para a doação de uma área pública na cidade de Santo André para implantar a universidade.

O projeto de lei 3962/2004, enviado ao Presidente da República e posteriormente ao Congresso Nacional, foi acompanhado pela EM Interministerial $n^{\circ}$ 179/2004/MEC/MP ${ }^{34}$, apresentando o projeto da nova universidade que registrava:

A expansão da rede de ensino superior e a ampliação do investimento em ciência e tecnologia são objetivos centrais do governo federal e foco do debate da reforma universitária. A criação de uma grande universidade no coração da indústria, maior região metropolitana do país é uma clara demonstração de compromisso com o desenvolvimento, a cultura e a democratização do acesso ao ensino superior. (BRASIL, 2004)

Demonstra ainda um forte desejo de interação entre projeto acadêmico, empresas e sociedade civil:

De suas características estratégicas decorrem algumas inovações e avanços institucionais, tais como: laboratórios integrados às empresas, [...] observatórios da sociedade e da economia com o propósito de gerar conhecimento sobretudo sobre as regiões do $A B C$, associação com a educação básica para a formação inicial e continuada de profissionais [...]projetando um novo padrão de integração entre a universidade e a educação básica (BRASIL, 2004)

A carta aponta um novo padrão da reforma universitária, que terá na UFABC seu maior laboratório, quando introduz seu diferenciado projeto pedagógico, no qual a organização administrativa será pautada por centros de conhecimento e não mais pelos departamentos:

A universidade deverá inicialmente ser integrada por três centros, que traduzem as características estratégicas: Centro de Tecnologias e Industria, Centro de Educação e Centro de Ciências Sociais ${ }^{35}$. (BRASIL, 2004).

O teor do documento do ministro Tarso Genro mostra que a criação da UFABC era um projeto ambicioso, com a intenção de inaugurar uma nova fase na educação superior brasileira a partir da região do $A B C$. E, embora fosse ambicioso em números (atendimento a 20.000 alunos) e valor (150 milhões de reais por ano), propunha "(...) uma estrutura organizacional, administrativa e acadêmica, extremamente simplificada, o que propiciará que a Universidade se torne ágil, eficiente e de baixo custo operacional". (BRASIL, 2004)

Em 26 de julho de 2005, o Congresso Nacional aprovou e o Presidente da República sancionou a lei no 11.145, criando a Universidade Federal do ABC, uma instituição multicampi,

\footnotetext{
${ }^{34}$ Cf. Anexo B - P.A. 13.364/2005-9 - Prefeitura Municipal de Santo André.

${ }^{35}$ Grifos nossos.
} 
com sede em Santo André, que previa para ess campus a contratação de 600 professores, 456 servidores técnicos-administrativos, 7.500 alunos de graduação e 1.500 alunos de pósgraduação. No mesmo mês, Fernando Haddad assumiu o Ministério da Educação e fez da implantação da UFABC uma prioridade no governo.

\subsection{O Projeto Pedagógico}

A trajetória do projeto pedagógico da UFABC inicia-se com um grupo de cientistas da UFRJ, ligados ao COPPE $^{36}$, que concebeu, nos anos 1990, uma proposta inovadora de curso universitário básico interdisciplinar, mas não encontrava condições favoráveis para sua implantação nas universidades tradicionais. Em maio de 1998, a COPEA (Coordenação de Programas de Estudos Avançados da UFRJ) promoveu um encontro na cidade de Angra dos Reis, quando foi concebido um manifesto alertando sobre a necessidade de uma reforma da Educação Superior no país, conhecido como o Manifesto de Angra. Esse documento foi incorporado, em 2004, pela Academia Brasileira de Ciências, em um novo documento Subsídios para a Reforma da Educação Superior ${ }^{37}$ - que chegou ao MEC por meio do Prof. Nelson Maculan, ex-reitor da UFRJ e então Secretário de Ensino Superior do Ministério da Educação (OLIVEIRA, 2010, p. 18).

A conjuntura dessa época, na esfera federal, foi favorável para que o MEC colocasse em teste a estrutura inovadora proposta pela Academia Brasileira de Ciências. O Secretário Nelson Maculan, convocou o professor Luiz Bevilacqua, principal defensor da proposta do grupo do COPPE, signatário do Manifesto de Angra e coautor do documento da Academia Brasileira de Ciências, a retomar sua proposta de um curso universitário interdisciplinar, com foco em ciência e tecnologia, para ser implantado em uma nova instituição de ensino superior na região do ABC Paulista, a UFABC.

A concepção da universidade teve um grupo de 36 idealizados, entre cientistas, intelectuais e acadêmicos. Foi formada uma comissão de implantação liderada pelo professor Luiz Bevilacqua e uma equipe de concepção do projeto pedagógico. ${ }^{38}$

\footnotetext{
${ }^{36}$ COPPE - Instituto Alberto Luiz Coimbra de Pós-Graduação e Pesquisa de Engenharia, da Universidade Federal do Rio de Janeiro - é o maior centro de ensino e pesquisa em engenharia da América Latina.

${ }^{37}$ Academia Brasileira de Ciências (2004).

${ }^{38} \mathrm{Cf}$. lista de idealizadores do projeto disponível em:

http://antigo.ufabc.edu.br/index.php?option=com_content\&view=article\&id=18\&/temid=71 Acesso em: 15/02/2017
} 
O projeto pedagógico proposto apresentava uma matriz interdisciplinar que considerava o progresso da ciência decorrente da intercessão de várias áreas do conhecimento cientifico e tecnológico. Consta no programa do Projeto Pedagógico:

Um sinal claro da nova era é o crescimento imergido de campos diferentes do conhecimento, o que conduz à pesquisa interdisciplinar. A fim de se inserir na reorganização da ciência e na interação entre ciência e tecnologia, a UFABC organiza seus cursos a partir de seis diretrizes principais, com as quais pretende inspirar os campos de pesquisa:

- Estrutura da Matéria;

- Energia;

- Processos de Transformação;

- Comunicação e Informação;

- Representação e Simulação (Matemática);

- Humanidades e Ciências Sociais Aplicadas.

Essa reorganização contrasta com a matriz clássica das universidades brasileiras, que, em geral, representam o que é adotado em muitos países: física, química, matemática e biologia. O novo método permite que os cursos fundamentais que compõem o conjunto sejam conduzidos por pessoas com diferentes formações. Uma equipe acadêmica capaz de delinear a aplicação e a conexão apropriada entre ciência e tecnologia. As disciplinas podem ser ensinadas, alternativamente, por pessoas com diferentes conhecimentos, com as respectivas ênfases. (UFABC, 2006)

A estrutura curricular divide-se em duas etapas:

1. Ciclos iniciais de três anos, correspondentes ao Bacharelado em Ciência e Tecnologia (BC\&T) ou Bacharelado em Ciência e Humanidades (BC\&H), que foi implantado posteriormente.

2. Ciclo complementar de um ano para licenciatura ou bacharelado específico (Física, Química, Matemática, Computação, Ciências Biológicas) ou Ciclo profissional de dois anos para oito modalidades de engenharia. A partir da criação do BC\&H, foram incorporados os bacharelados de Ciências Econômicas, Políticas Públicas, Relações Internacionais, Planejamento Territorial e Filosofia.

O ciclo inicial com duração de três anos confere o grau de Bacharel em Ciência e tecnologia ou em Ciência e Humanidades e pode ser terminal. Em parte, a critério do estudante, que determina uma parcela da matriz curricular do curso, esse desenho de formação permite ao egresso entrar imediatamente no mercado de trabalho. Os alunos que tiverem a intenção de prosseguir buscando uma formação especifica, após os três primeiros anos, também poderão fazê-lo e para isso poderão desenhar parte do ciclo inicial de acordo com suas aspirações profissionais ${ }^{39}$.

39 UFABC (2006). 


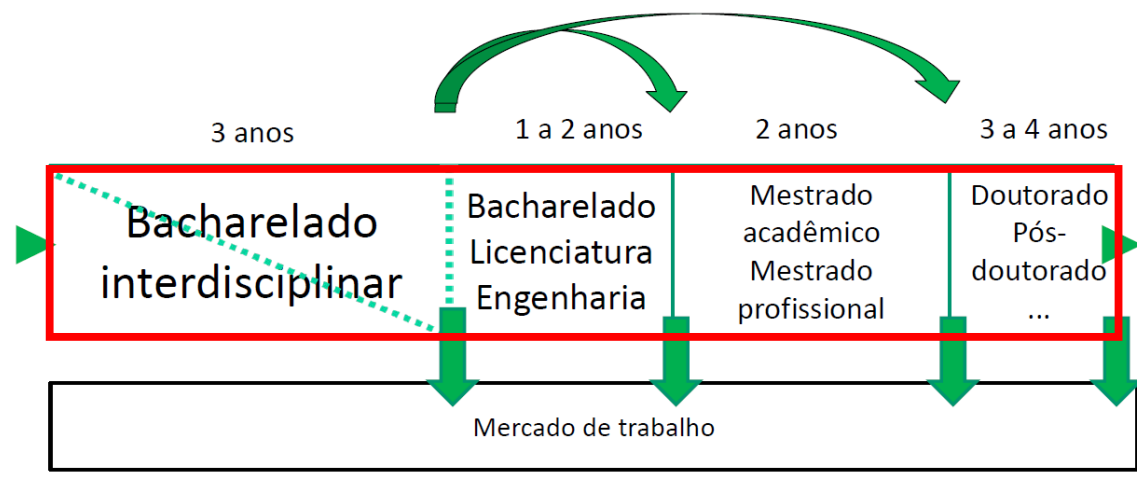

IMAGEM 40 Diagrama explicativo do progresso do aluno na UFABC. Autor: Prof. Klaus Capelle

Empenhando-se em se consolidar como a "Universidade de ponta para o século XXI", a UFABC pretende uma organização flexível, cuja estrutura acadêmico-administrativa é composta por três centros que, de certa forma, retratam as ações de descobrir, sistematizar e inventar que compõem, numa visão geral, o conjunto de atividades presentes da vida universitária. Essas atividades estão presentes nas diversas vocações universitárias, mas em doses um pouco diferentes. Assim, é própria aos cientistas dedicados a ciências naturais a atração pela descoberta, aos cientistas dedicados à matemática e computação, o gosto pelo rigor lógico e, aos engenheiros, a tarefa de inventar e inovar. Sendo assim, organizou-se a UFABC em três grandes centros, quais sejam:

- Centro de Ciências Naturais e Humanas

- Centro de Matemática, Computação e Cognição

- Centro de Engenharia, Modelagem e Ciências Sociais Aplicadas

Nessa visão pedagógica inovadora, é desejável que o objeto arquitetônico tenha relevância ao refletir os ideais educacionais. Seria necessária uma discussão ampliada sobre qual o objeto arquitetônico que melhor simbolizaria uma universidade nascida no século XXI.

\subsection{O Concurso Nacional para Projetos Arquitetônicos}

Definido o local da universidade, partiu-se para sua estruturação física. Mas como representar espacialmente uma Universidade no século XXI, com uma missão pedagógica tão definida?

A grande expectativa em relação ao objeto arquitetônico fez com que o MEC optasse pelo Concurso como melhor modalidade de licitação pela Lei Geral de Licitações e Contratos Administrativos - Lei 8.666/1993. Por meio de um concurso nacional, seria possível dar a 
visibilidade para um dos projetos mais relevantes do governo Lula, tanto por seu aspecto ideológico, quanto político e urbanístico.

O MEC e o Instituto de Arquitetos do Brasil (IAB) acordaram um termo de cooperação técnica para a promoção e organização do Concurso. Coube à Prefeitura de Santo André, por meio da SDUH, definir parâmetros urbanísticos e subsidiar toda a documentação técnica do terreno para compor o Termo de Referência. Assim, cada órgão contribuiu para estruturar o Termo de Referência que comporia o edital do Concurso.

O Parecer N. $128 / 2005^{40}$ emitido pelo CODESUR - Conselho de Desenvolvimento Urbano - reuniu as diretrizes de órgãos da Prefeitura afetos ao projeto da UFABC e, dentre as principais orientações, estavam:

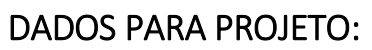

QUADRO DISCENTE:

CAPACIDADE INICIAL $=1.000$ ALUNOS ( MAR 2006)

CAPACIDADE FINAL = 20.000 ALUNOS (Alunos de graduação e pós-graduação)

QUADRO DOCENTE E ADMINISTRATIVO:

Fonte: Lei 3.962-B/2004

CARGOS DE DIREÇÃO E FUNÇÕES GRATIFICADAS = 146 FUNCIONARIOS

PROFESSORES $=600$ FUNCIONÁRIOS

CARGOS DE NIVEL INTERMEDIARIO = 300 FUNCIONARIOS

CARGOS DE NIVEL SUPERIOR = 456 FUNCIONÁRIOS

INDICES PARA CALCULO DE LOTAÇÃO

Fonte PSA COE LEI 8.065 - ANO 2.000

PRESTAÇÃO DE SERVIÇOS DE EDUCAÇÃO

SALA DE AULA $=1,5 \mathrm{~m}^{2} /$ pessoa

LABORATORIO E OFICINAS $=4,00 \mathrm{~m}^{2} /$ pessoa

ATIVIDADE NÃO ESPECIFICADA E ADMINISTRATIVA $=7,00 \mathrm{~m}^{2} /$ pessoas

${ }^{40} \mathrm{Cf}$. Anexo C - Diretrizes do CODESUR 


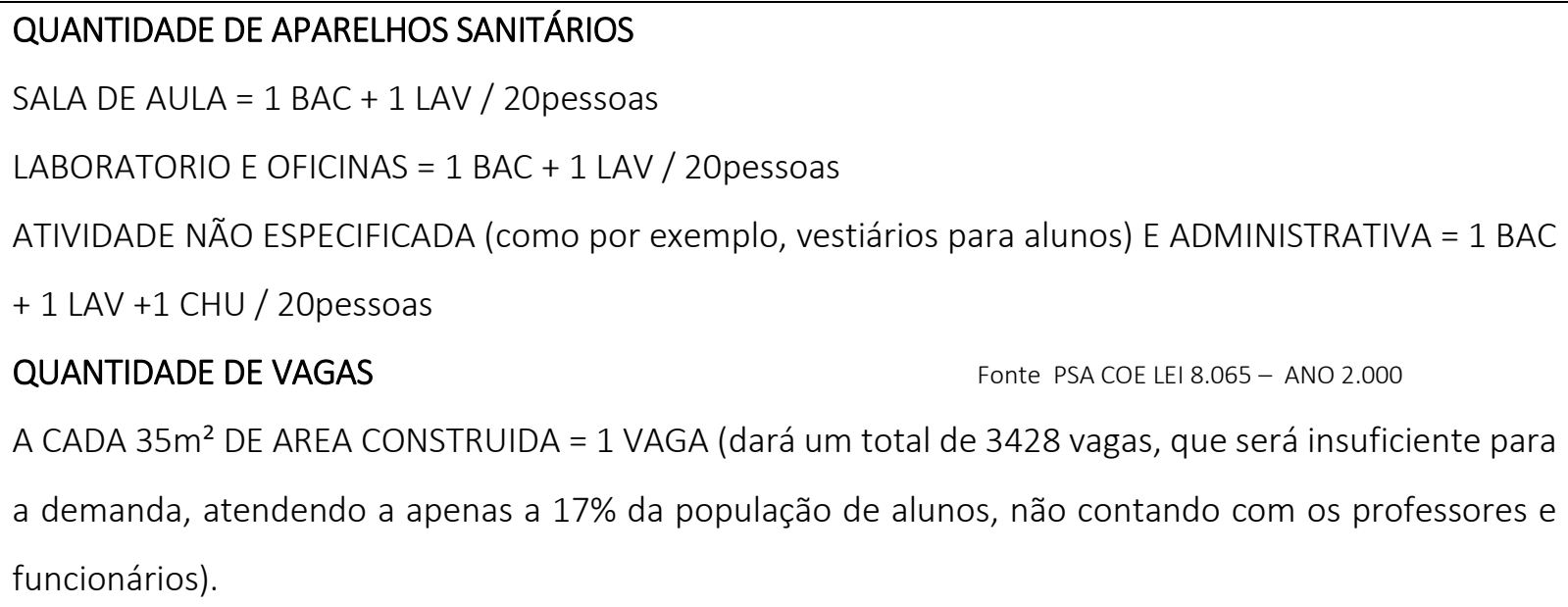

\section{DETERMINAÇÕES DO CODESUR:}

A valorização arquitetônica e construtiva dos espaços urbanos e dos edifícios;

Mitigar impactos de vizinhança a longo prazo: Licenciamento Ambiental Municipal e Relatórios de Impacto (EIV/RIV);

Faixa de 50 m de compensação ambiental ao longo do Rio Tamanduateí, a partir da crista do talude das margens do rio;

Necessidade de plantio de 1667 mudas/ha para áreas de compensação ambiental;

Campus aberto, integrado à cidade - conceito de multicampi - portanto há a possibilidade de parcelamento do lote;

Como o terreno localiza-se em área de uso misto, residencial de media densidade;

Área verde $=10 \%$ da área verde estará concentrada em perímetro determinado, integrado à cidade;

Previsão de comércio de atendimento às necessidades dos estudantes (papelaria, xerox, livraria), interno ao campus;

Previsão de acesso para o pedestre, da Estação Ferroviária de Santo André/Terminal de ônibus e o campus e passeios no entorno do campus de 4 metros e previsão de pontos de ônibus com abrigo; Indicar acesso e gravar no projeto a área para estacionamento de veículos para coleta de lixo e carga e descarga de mercadorias, estacionamento para vans e ônibus fretado. Embarque e desembarque; Prever baia para embarque e desembarque de estudantes por veículo particular, transporte coletivo, ônibus de linhas regulares e taxis;

Atender legislação municipal, estadual e federal;

Especial atenção a NBR9050 no que diz respeito a mobilidade urbana;

Espaços para atendimento à comunidade. 
Cabe lembrar que a Secretaria de Cultura e o Museu de Santo André Dr. Octaviano Armando Gaiarsa forneceram dados sobre o edifício do Matadouro Municipal.

A partir dos índices urbanísticos determinados pela prefeitura de Santo André, a Comissão de Implantação, sob a liderança do professor Luiz Bevilacqua, concebeu um Programa de Necessidades para atender a demanda de 9.000 alunos, considerando as perspectivas do novo programa pedagógico, cuja premissa era a existência de centros do conhecimento, como já visto anteriormente.

\begin{tabular}{|c|c|c|c|c|}
\hline \multicolumn{5}{|c|}{ PROGRAMA DE NECESSIDADES PARA UNIVERSIDADE FEDERAL DO ABC } \\
\hline \multirow{2}{*}{\multicolumn{2}{|c|}{ Descrição }} & \multicolumn{2}{|c|}{ Área Demandada } & \multirow{2}{*}{ Observações } \\
\hline & & 1 Fase & Final $\mathrm{m}^{2}$ & \\
\hline \multirow{2}{*}{\multicolumn{2}{|c|}{$\begin{array}{l}\text { Laboratórios Ensino Física, Química } \\
\text { e Bioquímica }\end{array}$}} & 2000 & 2000 & 2 labs. Física (100 alun./lab.) \\
\hline & & 2000 & $\angle 000$ & 3 labs. Química-Bioquimica. (100 alun./lab) \\
\hline \multicolumn{2}{|c|}{$\begin{array}{l}\text { Laboratórios de Ensino e Ensaios } \\
\text { Engenharia }\end{array}$} & 900 & 1800 & Laboratórios de ensino e ensaios que servem também em parte para serviços e pesquisa \\
\hline \multirow{4}{*}{$\begin{array}{l}\text { Labor. de } \\
\text { Pesquisa }\end{array}$} & Física & 2300 & 2300 & \multirow{3}{*}{$\begin{array}{l}\text { Estes laboratórios devem incluir espaço para salas individuais p/ } 100 \text { docentes e espaço } \\
\text { comum para alunos de pós grad.( aprox.300) na área experimental e técnicos (aprox. 100). } \\
\text { Previsão microscópios, espectrômetros, etc.. } 200 \mathrm{~m}^{2} \text { com pé direito de } 9 \text { metros. }\end{array}$} \\
\hline & Quim. Bioquim. & 2300 & 2300 & \\
\hline & Engenharias & 2400 & 4800 & \\
\hline & Oficinas & 500 & 500 & Oficinas de serviço para labs e campus \\
\hline \multirow{3}{*}{ Salas de aula } & Anfiteatros A & 1650 & 1650 & 11 anfiteatros para cerca de 110 alunos. Três com computadores \\
\hline & Anfiteatros B & 2100 & 2100 & 12 anfiteatros para cerca de 130 alunos com mesa de demonstração. \\
\hline & Salas comum & 840 & 840 & 12 salas para 60 alunos \\
\hline \multirow{4}{*}{$\begin{array}{l}\text { Núcleo de } \\
\text { computação }\end{array}$} & Máquinas & 1780 & 1780 & Espaço para o núcleo com aas máquinas servidores apoio técnico etc \\
\hline & Labs e usuarios & 600 & 600 & Espaço com PC's para uso de alunos de cursos e outros usuários. \\
\hline & $\begin{array}{l}\text { Sala de alunos } \\
\text { pós graduação }\end{array}$ & 150 & 700 & Espaço para alunos de pós de todas as áreas (inicial 70 alunos e final 300 alunos) \\
\hline & Sala de prof. & & 570 & Gabinetes para cerca de 40 docentes \\
\hline \multicolumn{2}{|l|}{ Salas de docentes } & 3400 & 6800 & Salas para 240 (inicial) e 480 (final) docentes, secretarias, sala de reuniões \\
\hline \multicolumn{2}{|l|}{ Biblioteca } & 1000 & 1880 & $\begin{array}{l}\text { Biblioteca para cerca de } 60 \text { mil volumes até } 100 \text { mil fase final, administração, manutenção do } \\
\text { acervo e sala de estudos. }\end{array}$ \\
\hline \multicolumn{2}{|c|}{ Núcleo de estudos avançados } & 400 & 400 & Direção, administração e organização de eventos. \\
\hline \multicolumn{2}{|c|}{ Instituto de cognição } & 600 & 1200 & Direçao, salas de pesquisadores e alunos, labs de computação e equipamentos RMN e \\
\hline \multicolumn{2}{|l|}{ Sala de estudos } & 500 & 1000 & Sala de estudo alunos de graduação (capac. Inicial 450 alunos final 900) \\
\hline \multirow[t]{2}{*}{ Anfiteatros } & $\begin{array}{l}\text { Anfiteatro } \\
\text { pequeno }\end{array}$ & & 120 & $\begin{array}{l}\text { Na estapa final para pequenas audiencias (100 pessoas). Peferivelmente junto ao Nucleo de } \\
\text { Estudos Avançados }\end{array}$ \\
\hline & Anfiteatros & 600 & 600 & Anfiteatro para grandes públicos (500 lugares). \\
\hline \multicolumn{2}{|l|}{ Administraçao } & 940 & 940 & Reitoria, pro-reitorias, prefeitura do Campus, núcleo de assistência ao estudante, etc. \\
\hline \multicolumn{2}{|l|}{ Refeitórios } & 420 & 840 & Dois refeitórios. Um tipo mensal maior e outro menor a la carte ou "buffet". \\
\hline \multicolumn{2}{|c|}{ Alojamento de estudantes } & 1200 & 6000 & Alojamento para 100 estudantes e final 500 estudantes \\
\hline \multirow{2}{*}{$\begin{array}{l}\text { Lojas e } \\
\text { Estacionamento }\end{array}$} & Estacionamento & 10000 & 19800 & Estacionamento para cerca de 1200 veículos. Edifício garagem. \\
\hline & $\begin{array}{l}\text { Centro cultural e } \\
\text { Lojas }\end{array}$ & 1800 & 3600 & $\begin{array}{l}\text { Neste prédio deve estar um centro cultural com } 1 \text { teatro } 1 \text { cinema, livraria, papelaria e } \\
\text { pequenas lojas. }\end{array}$ \\
\hline \multicolumn{2}{|l|}{ TOTAL $\mathrm{m}^{2}$} & 38380 & 65120 & \\
\hline
\end{tabular}

IMAGEM 41 Quadro informativo das fases de implantação do Campus Santo André. Fonte SDUH/DDPU

Observa-se que o programa de necessidades inicial previa a instalação da Universidade em duas etapas: uma primeira fase, cuja área construída seria $38.000 \mathrm{~m}^{2}$ e outros $65.000 \mathrm{~m}^{2}$ 
na fase final. Tal dado revela uma certa atenção à questão da disponibilidade dos recursos do MEC, em consonância com as orientações do Ministério do Planejamento ${ }^{41}$.

Após o alinhamento das informações entre MEC, IAB e PMSA/SDUH, o edital foi finalizado e, em 31 de outubro de 2005, foi lançado, em nível nacional, o Concurso Público Nacional de Projeto de Arquitetura para o Campus da Universidade Federal do ABC, na cidade de Santo André. Na solenidade, foram empossados o reitor e o vice-reitor pro tempore, Hermano Tavares e Luiz Bevilacqua, e dela participaram o ministro Fernando Haddad; o prefeito de Santo André, João Avamileno, os prefeitos de municípios da região e o presidente do IAB Nacional, Demetre Anastassakis. ${ }^{42}$

O Termo de Referência se inicia com um breve relato contextualizando a UFABC e já, no primeiro parágrafo, esclarece que a UFABC tem um caráter multicampi e pode ser ampliada para outras cidades:

A UNIVERSIDADE FEDERAL DO ABC é uma das primeiras universidades federais do Brasil a ser inaugurada no século XXI. Desta forma, nasce com forte potencial para a inovação e diversificação, propondo uma estrutura que conjugue flexibilidade acadêmica e curricular com altos padrões de qualidade.

A UFABC será construída em vários locais, nos municípios do Grande $A B C$, seguindo o conceito de multicampi, conforme prevê a Lei que a criou. No futuro, deverá atender, no máximo, 20 mil alunos. O campus de Santo André comportará, no máximo, 9.000 alunos e 600 docentes. Para efeito de projeto considerar períodos com $40 \%$ de alunos de manhã, $40 \%$ de alunos a tarde e $20 \%$ a noite. ${ }^{43}$.

Em seguida, discorre o texto sobre as expectativas da Universidade em relação ao novo conjunto de edifícios a ser concebido. Reitera a importância de o terreno pertencer à área do Projeto Eixo Tamanduatehy e que a expectativa é de que a Universidade promova a reconversão urbana, econômica e social por meio do incentivo a novos empreendimentos em vazios urbanos subutilizados e plantas industriais desativadas. Há também a expressa orientação de que a universidade atenda a parâmetros construtivos, ambientais e de mobilidade compatíveis com o século XXI, inclusive em relação à preservação do patrimônio no caso o Matadouro -, como se pode observar no item Patrimônio Histórico, do Termo de Referência considerado na concepção da proposta:

\footnotetext{
${ }^{41}$ Cf. Interministerial n. 179/2004/MEC/MP - Anexo B

42 BRASIL. MEC lança concurso para projeto arquitetônico da UFABC. 31 de outubro de 2005. Disponível em: http://portal.mec.gov.br/busca-geral/212-noticias/educacao-superior-1690610854/4693-sp-109011493 Acesso em $15 / 01 / 2016$

${ }^{43}$ Cf. Anexo D - Minuta do Termo de Referência - Fonte DDPU-PMSA
} 
PATRIMONIO HISTÓRICO

Estudar as instalações do antigo matadouro municipal, constituído pelo conjunto de dois edifícios (prédio principal e prédio secundário), muro de arrimo e caixa d'água, (conforme localização em planta anexa) para, facultativamente, apresentar propostas de preservação e requalificação, considerando:

Manutenção das características espaciais e da técnica construtiva existente;

Integração espacial e funcional das edificações propostas com o conjunto a preservar;

Adequação das edificações eventualmente a preservar ao novo uso, preferencialmente como espaço de convivência;

Garantir visualização do conjunto, integrando-o à paisagem urbana ${ }^{44}$.

Em relação às áreas para as atividades acadêmicas, foram assim resumidas:

1. Corpo Administrativo $=940,00 \mathrm{~m}^{2}$

2. Corpo Docente $=6.800,00 \mathrm{~m}^{2}$

3. Corpo Discente

Ciências Naturais $=7.930,00 \mathrm{~m}^{2}$

Engenharias $=9.730,00 \mathrm{~m}^{2}$

Matemática e Cognição $=4.730,00 \mathrm{~m}^{2}$

4. Núcleos de Apoio $=5.200,00 \mathrm{~m}^{2}$

5. Outras Atividades $=61.200,00 \mathrm{~m}^{2}$

TOTAL $=96.530,00 \mathrm{~m}^{2}$

Dada a complexidade do assunto, também fez parte do Termo de Referência um diagrama, elaborado pela equipe da SDUH, cuja finalidade era ilustrar e clarificar a estrutura física demandada para a nova universidade.

${ }^{44}$ Cf. Anexo D - Minuta do Termo de Referência Fonte DDPU-PMSA. 


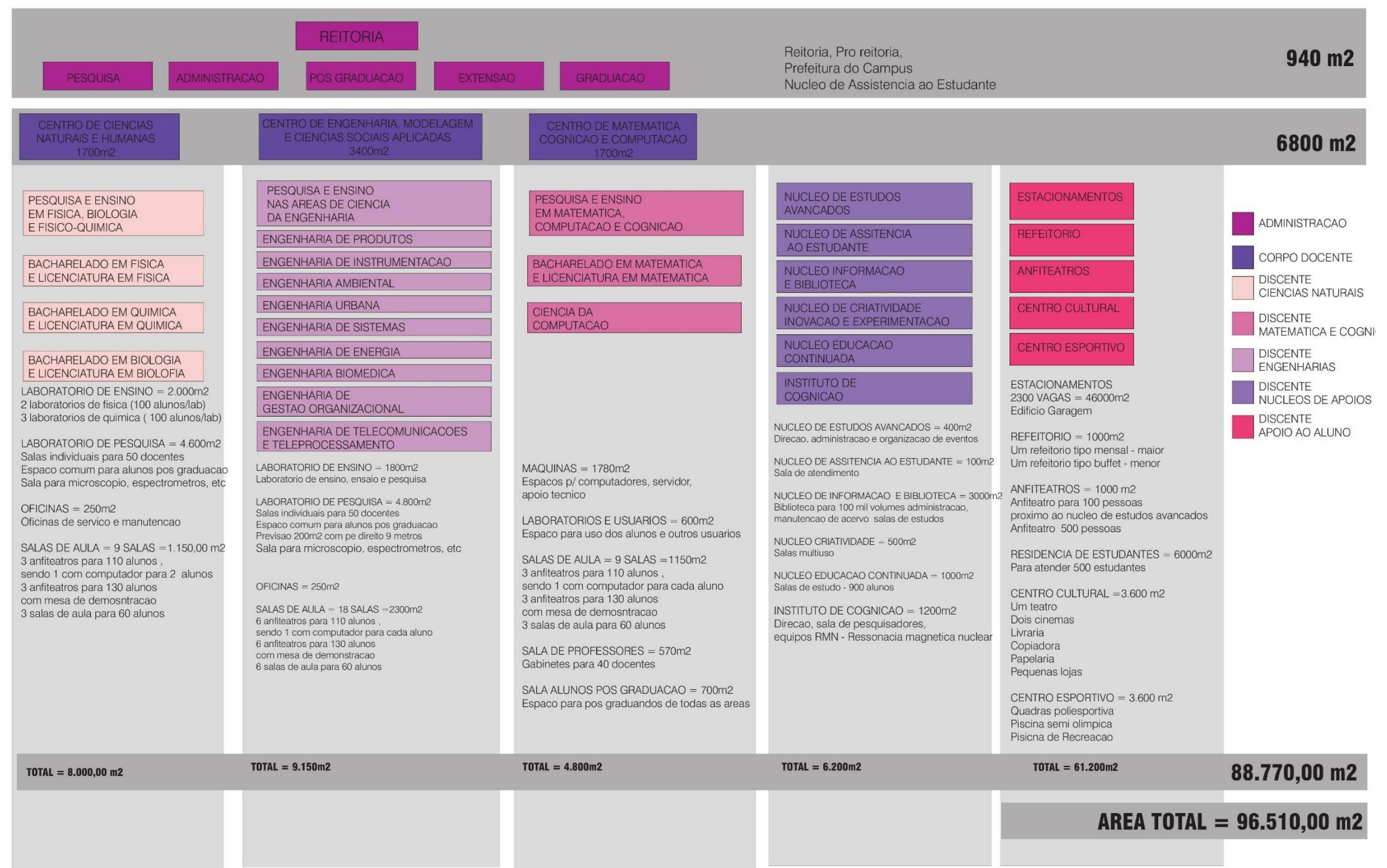

IMAGEM 42 Diagrama do programa de necessidades da UFABC

Fonte: SDUH/DDPU 
Participaram do Concurso cinquenta escritórios de arquitetura de vários estados do Brasil, com forte participação dos escritórios paulistas, como se observa na tabela a seguir:

\begin{tabular}{|c|c|}
\hline REPRESENTANTE EQUIPE & $\begin{array}{l}\text { Part. por } \\
\text { Estado }\end{array}$ \\
\hline BRASILIA & \multirow{6}{*}{$10,00 \%$} \\
\hline PAULO HENRIQUE PARANHOS & \\
\hline NONATO VELOSO & \\
\hline SERGIO ROBERTO PARADA & \\
\hline $\begin{array}{l}\text { FILIPE BERUTTI MONTE SERRAT } \\
\end{array}$ & \\
\hline THAIS LOHMANN PROVENZO & \\
\hline CEARÁ & \multirow{3}{*}{$4,00 \%$} \\
\hline ANTONIO CARVALHO NETO & \\
\hline MARCELO MAGALHÃES & \\
\hline MINAS GERAIS & \multirow{7}{*}{$12,00 \%$} \\
\hline JOÃO FRANCISCO REIS VILELA & \\
\hline JOEL CAMPOLINA & \\
\hline ANDRE LUIZ PRADO OLIVEIRA & \\
\hline PAULO PONTES CORREIA NEVES & \\
\hline PAULA PRATA CARNICERO & \\
\hline SYLVIO EMRICH DE PODESTÁ & \\
\hline PARANÁ & \multirow{3}{*}{$4,00 \%$} \\
\hline KÓ YAMAWAKI & \\
\hline BÓRIS MADSEN CUNHA & \\
\hline PERNAMBUCO & \multirow[b]{2}{*}{$2,00 \%$} \\
\hline $\begin{array}{l}\text { JOÃO DOMINGOS PETRIBU DA C. } \\
\text { AZEVEDO }\end{array}$ & \\
\hline SANTA CATARINA & \multirow{3}{*}{$4,00 \%$} \\
\hline AMERICO ISHIDA & \\
\hline MAURICIO ADRIANI & \\
\hline ACRE & \multirow{2}{*}{$2,00 \%$} \\
\hline N’DIOGOU DIENE & \\
\hline RIO G DO SUL & \multirow{4}{*}{$6,00 \%$} \\
\hline ANDREONI DA S PRUDENCIO & \\
\hline GABRIEL CRUZ GRANDÓ & \\
\hline ELYSEU VICTOR MASCARELLO & \\
\hline
\end{tabular}

\begin{tabular}{|l|l|}
\hline REPRESENTANTE EQUIPE & $\begin{array}{l}\text { Part. } \\
\text { por } \\
\text { Estado }\end{array}$ \\
\hline SÃO PAULO & \\
\hline GLAUCO VITOR DIAS & \\
\hline LILIAN DALPIAN & \\
\hline HECTOR VIGLIECCA \\
\hline PATRICIA BERTACCHINI \\
\hline EUCLIDES GÓES M DE OLIVEIRA \\
\hline JOSÉ CARLOS RIBEIRO \\
\hline BRUNO HIRANO ROBERTO PADOVANO \\
\hline VINICIUS HERNANDES DE ANDRADE \\
\hline MAURILIO LIMA LOBATO \\
\hline ARAKEN MARTINHO \\
\hline CLAUDIO LIBESKIND \\
\hline ANA MARIA SANTILLI \\
\hline MARIA GABRIELA MENDES DE PONTES \\
\hline CELSO NAKAMOTO \\
\hline PABLO ALEKSITCH \\
\hline CIRO FELIPE PIRONDI \\
\hline JOSE BERNARDO ROLIM ROSA \\
\hline RENATA HELOISA DE TONISSI \\
\hline JOSE AUGUSTO FERNANDES ALY \\
\hline ADRIANA TACACO OZAKI \\
\hline FRANCISCO SPADONI \\
\hline SERGIO DE PAIVA \\
\hline WILIAN POMBEIRO \\
\hline JOSE MARIA DE MACEDO FILHO \\
\hline PAULO RICARDO MONTEIRO \\
\hline THAIS AQUINO ALVES DA CUNHA \\
\hline GOIAS \\
\hline MONICA TORMINN CROSARA \\
\hline
\end{tabular}

IMAGEM 43 Lista dos arquitetos participantes do Concurso para Projetos Arquitetônicos da UFABC. Fonte SDUH/DDPU

A Comissão Julgadora, convidada por consultor do Instituto de Arquitetos do Rio de Janeiro para o Concurso de Projetos Arquitetônicos da UFABC, foi composta por Jaime Lerner, Rosana Denaldi, Walmir Lima Amaral, Frank Svenvson, Pablo César Benetti, João Honório Mello Filho e Leonardo Barci Castriota. O resultado foi divulgado em 13 de janeiro de 2006. A seguir, são apresentados escritórios de arquitetura vencedores, seus projetos e os respectivos memoriais, conforme divulgado pelo site Vitruvius ${ }^{45}$ :

${ }^{45}$ Disponível em: http://www.vitruvius.com.br/revistas/read/projetos/06.062/2612 Acesso em 18/06/2016 
IMAGEM 44 Sandra Llovet e Cláudio Libeskind. Foto: Monolito, 2012

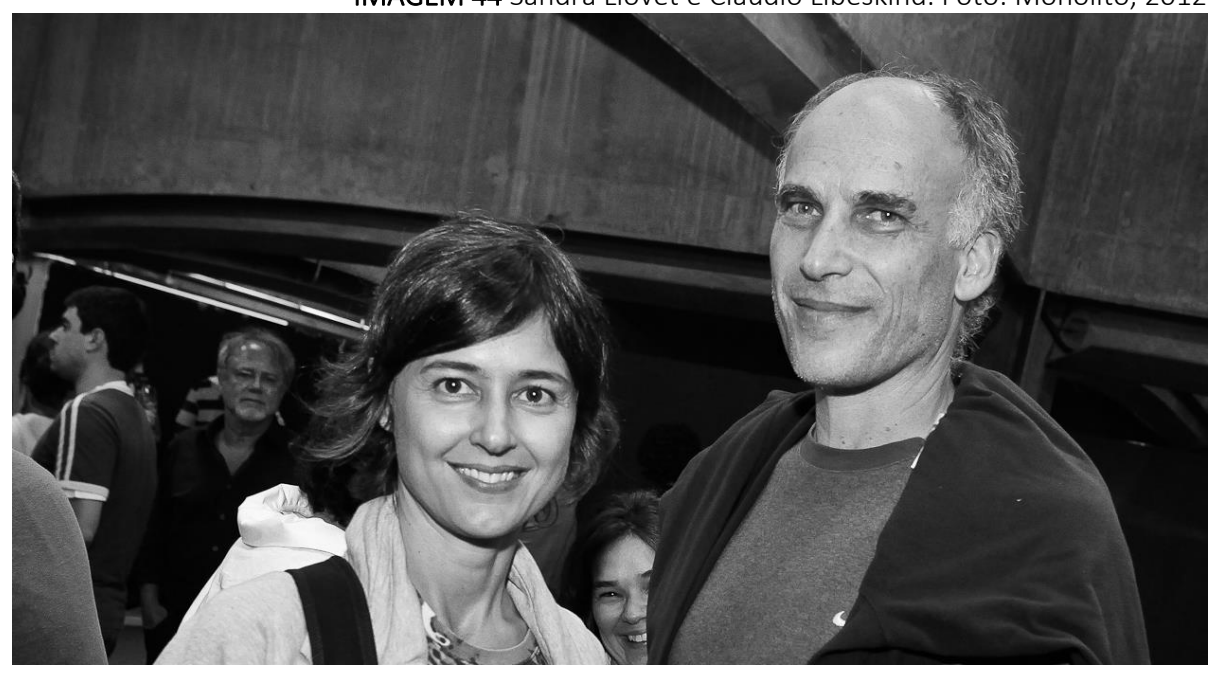

10. Lugar:

Libeskindllovet Arquitetos, São Paulo

Claudio Libeskind

Sandra Llovet

Mario Lotfi

David Ruscalleda 


\section{Memorial}

Nesta cidade, feita de sucessivas adições, de fragmentos, o projeto sobrepõe outros, criando com sua implantação uma determinada ordem e uma rica variedade de espaços públicos, um grande complexo gerador de atividades promovendo o encontro da população.

O projeto para o novo campus da UFABC procurou ser implantado com o mínimo de interferência no terreno natural. Partimos da ideia de que o espaço de uma faculdade, lugar onde as pessoas devem estar em permanente contato, deveria procurar uma relação mais íntima com a cidade, com espaços de convívio.

A partir de um eixo principal articulador dos diversos blocos correspondentes a cada uma das demandas, e seguindo os platôs gerados pelas cotas existentes na Rua Abolição, no prédio do matadouro e na Av. dos Estados, foram criadas três praças alternando espaços abertos e cobertos com áreas verdes e pavimentadas.
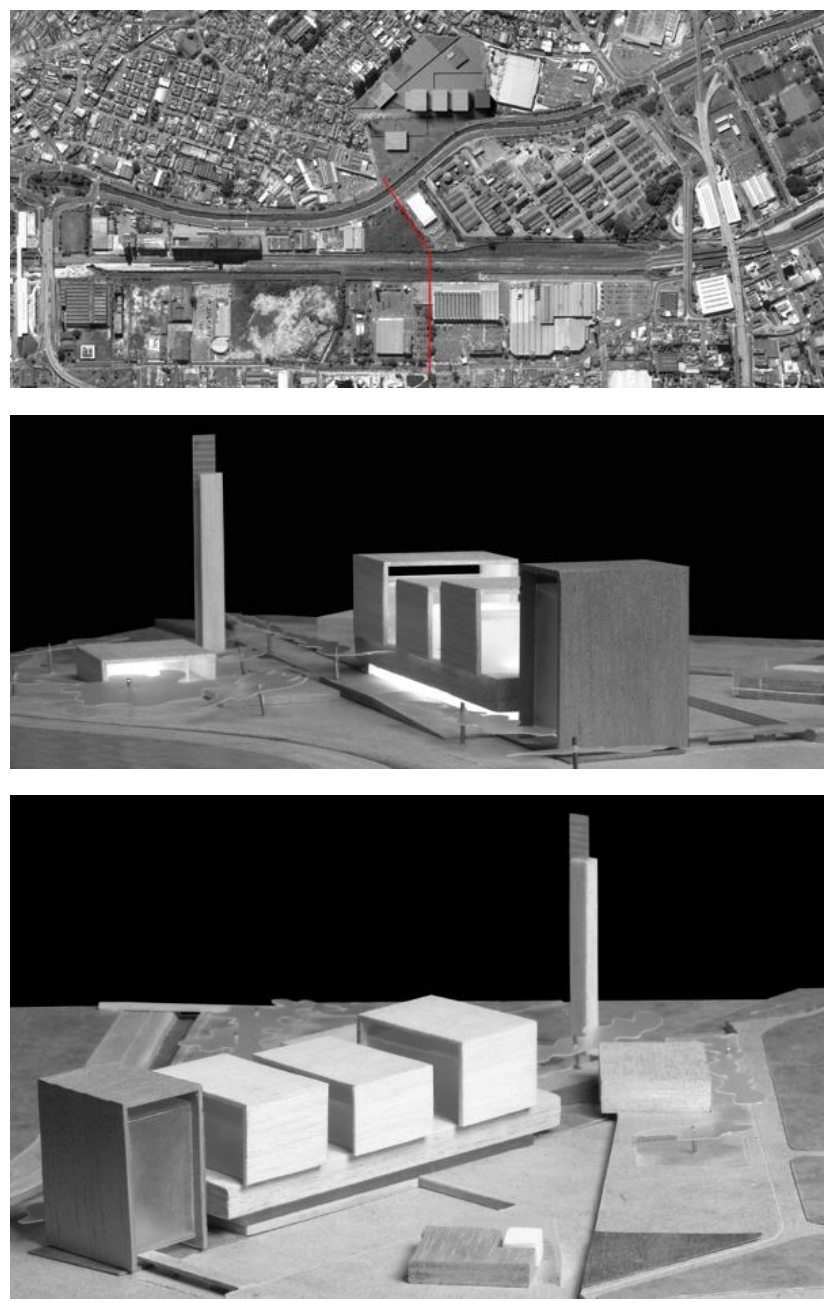

\section{Acesso 1: O novo eixo}

Trata-se do acesso das pessoas que chegam do metrô de superfície, do terminal rodoviário, do terminal dos trólebus e de carro ou ônibus pela Av. dos Estados. Este eixo interliga o prédio principal, o residencial e o esportivo, todos em diferentes níveis, dando unidade ao conjunto e articulando o projeto.

\section{Acesso 2: A praça da memória}

Esta nova entrada de pedestres acessa diretamente o nível do prédio principal a través de uma descida pelo terreno no meio das árvores que abraçam o antigo matadouro.

\section{Acesso 3: A praça do sol}

Chegando no campus, o pedestre se depara com um amplo espaço público, onde está o centro cultural, mais perto da cidade e em contato direto com a população.

\section{Acesso 4: O parque do relógio}

O intuito deste acesso é interligar, através de passarelas elevadas sobre a Av. dos Estados e a estrada de ferro, a parte da cidade que hoje se encontra ilhada por causa destas barreiras. Esta transposição uniria o Parque do Relógio com o Parque Celso Daniel, criando uma continuidade paisagística e configurando ao mesmo tempo outro trecho do parque linear.

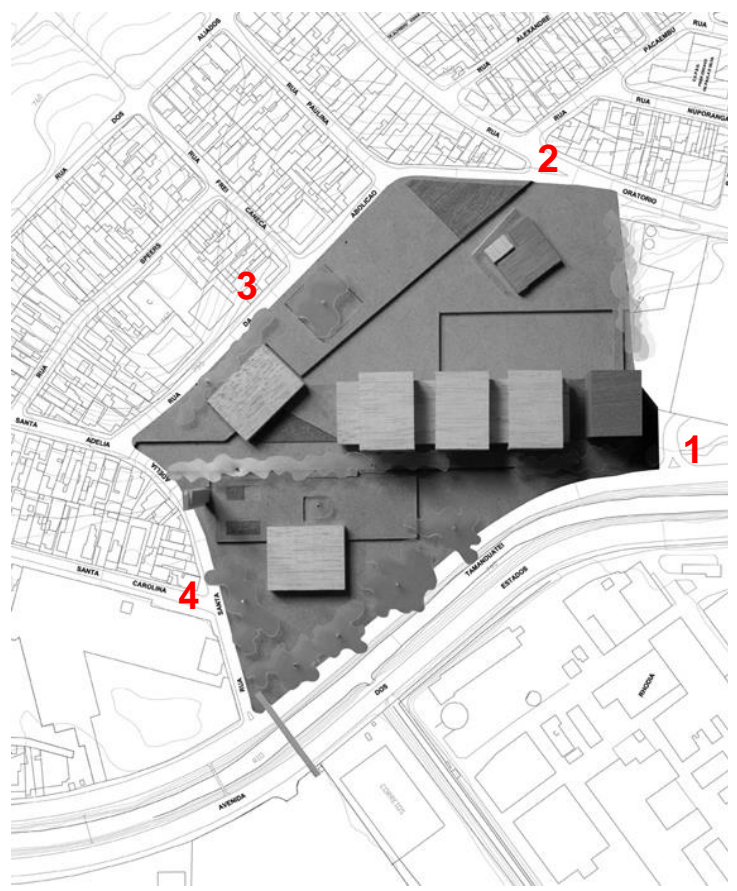

IMAGEM 46 Vista superior da maquete da proposta e os Eixos de Acesso. Fonte: site Vitruvius 
Junto à rua abolição, configura-se uma praça de entrada, com dois andares de estacionamento aproveitando o desnível do terreno. Sobre essa grande laje, emerge o bloco cultural num extremo e um espelho de água no outro. É uma caixa fechada com o teatro, os cinemas, os anfiteatros e algumas pequenas lojas.

Através de um grande vazio, numa área de vegetação existente, se realiza o acesso à Praça da Memória. Nela se encontra o prédio principal, corpo único, com um grande embasamento que abriga a parte administrativa, e os núcleos no térreo, e as salas de aula e anfiteatros com pé direito maior nos outros dois pavimentos. Desta grande base, saem os três blocos correspondentes ao Centro de Engenharia, Modelagem e Ciências Sociais Aplicadas num extremo, o Centro de Ciências Naturais e Humanas no outro, e o Centro de Matemática, Cognição e Computação no meio. As salas do corpo docente, foram colocadas no pavimento superior de cada um dos blocos, visando aproveitar as melhores vistas.
IMAGEM 47 Cortes e elevações. Fonte site Vitruvius
O prédio residencial destaca se deste conjunto, invertendo o seu posicionamento, para a melhor insolação das suas unidades. No último pavimento, o terraço coberto vira uma grande sala de encontro.

Nesta praça, cujo nome remete à memória do antigo prédio do matadouro, encontra-se também a área destinada a restaurantes. Aproveitando o prédio existente, o projeto pretende recuperar a estrutura, liberando-a e conservando as qualidades arquitetônicas essenciais do antigo prédio, acrescentando um toque de emoção e contemporaneidade. O espaço interno vai ser usado como refeitório colocando as cozinhas na parte posterior, ligadas ao estacionamento.

Foram previstas três possíveis fases de construção. Na primeira etapa seria construído o eixo central, com o prédio principal, a laje que conforma a praça da memória, o estacionamento embaixo dela e a torre do relógio. Nesta etapa, as quadras poderiam ser construídas no próprio terreno. Na segunda etapa, seria construída a praça do sol, com o centro cultural e o resto do estacionamento. $\mathrm{Na}$ terceira, para concluir o campus, seriam construídos o centro esportivo e o prédio residencial.
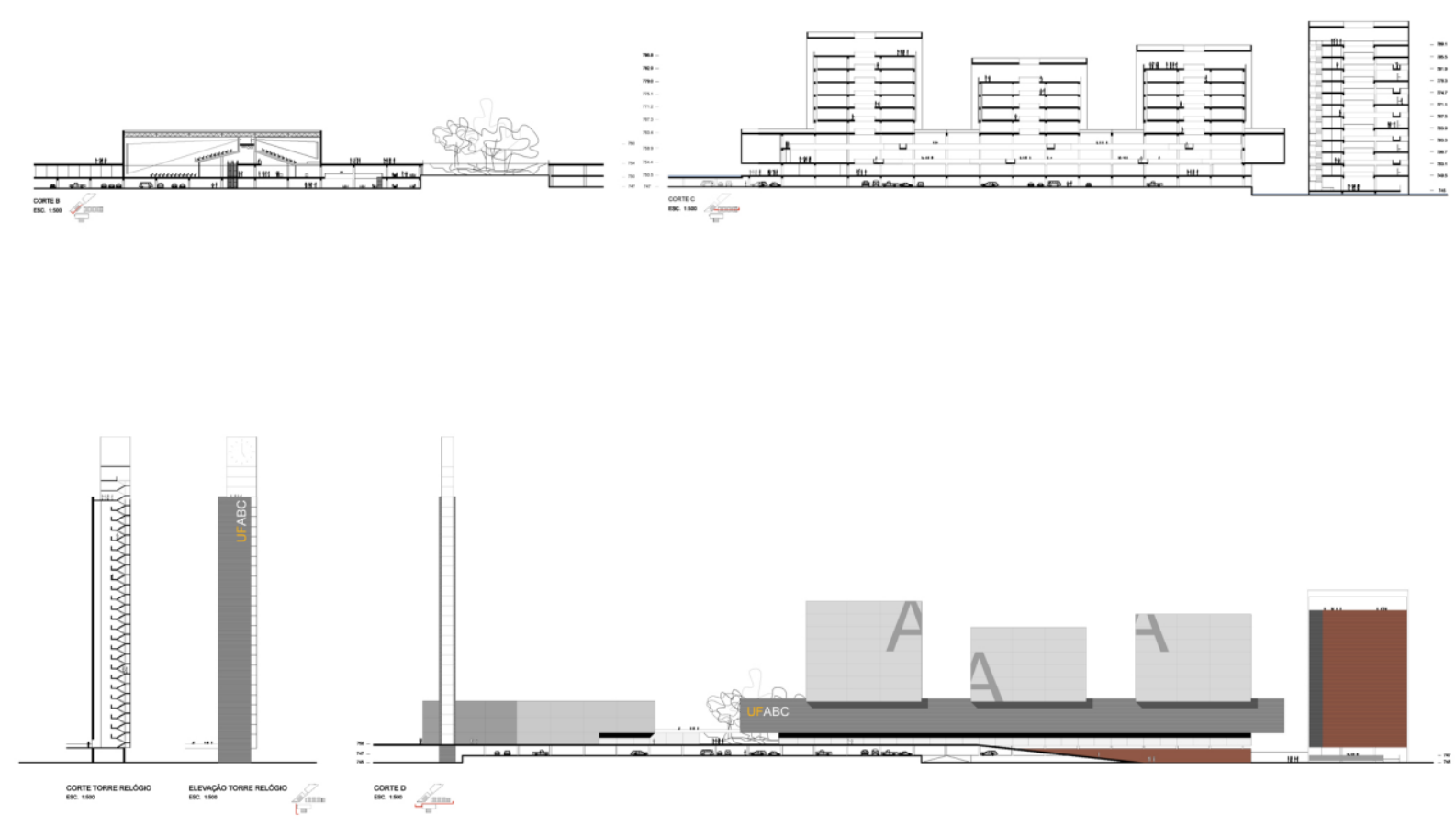


\section{Estrutura e materiais}

A estrutura de concreto com malha de $10 \times 10 \mathrm{~m}$ será pré-moldada para o estacionamento e a base do prédio docente e convencional nos blocos em altura, pela dificuldade de construção. As fachadas cegas foram pensadas como grandes empenas em placas de concreto pré-fabricadas, com revestimento em zinco na sua base e concreto aparente nos blocos.

Foram escolhidos materiais naturais, como vidro, zinco, concreto e madeira. O zinco é um material nobre, duradouro e elegante além de transmitir modernidade ao conjunto.

A caixilharia será de alumínio para melhor proteção contra o ruído da Av. dos Estados, sendo colocadas crises de madeira nas fachadas orientadas a norte, leste e oeste, deixando um espaço para circulação de ar.

IMAGEM 48 Plantas de Implantação.

Fonte site Vitruvius

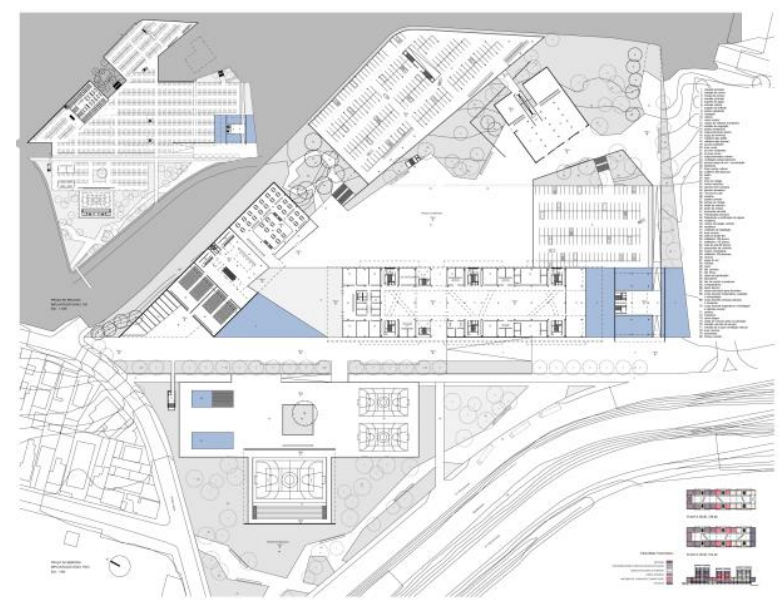

IMAGEM 49 Perspectivas

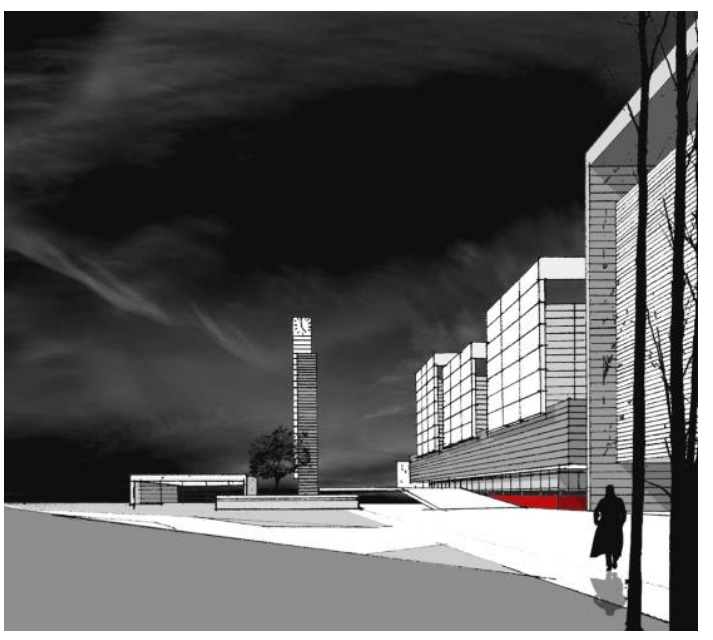

\section{Conforto ambiental}

As edificações foram projetadas conforme as condições de latitude e de topografia, visando a uma arquitetura bioclimática que controle iluminação, ventilação, insolação térmica, minimizando o uso de ar condicionado.

O prédio principal, possui um sistema de circulação de ar nas salas de aula e anfiteatros situados no embasamento dispensando o uso de ar condicionado.

Todos os blocos possuem ventilação natural, o ar aquecido sai naturalmente pelo "efeito chaminé".

A energia para aquecer a água dos chuveiros é fornecida por painéis fotovoltaicos posicionados na face norte da cobertura do prédio residencial e da quadra esportiva. Será previsto um circuito paralelo a gás que funcionará somente na falta de sol.
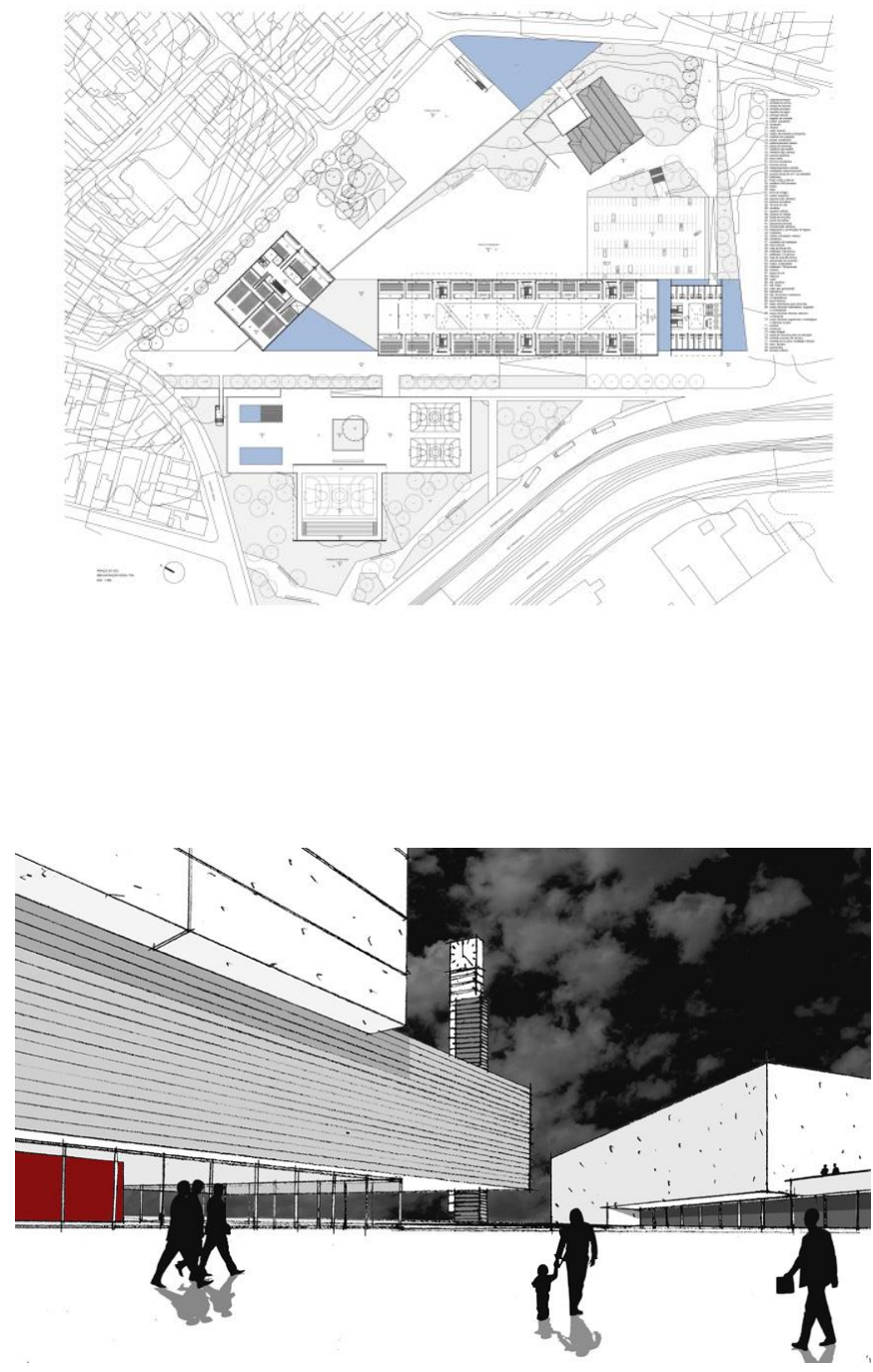
IMAGEM 50 Arq. Paulo Henrique Paranhos.

Foto: http://semauestacio.blogspot.com.br

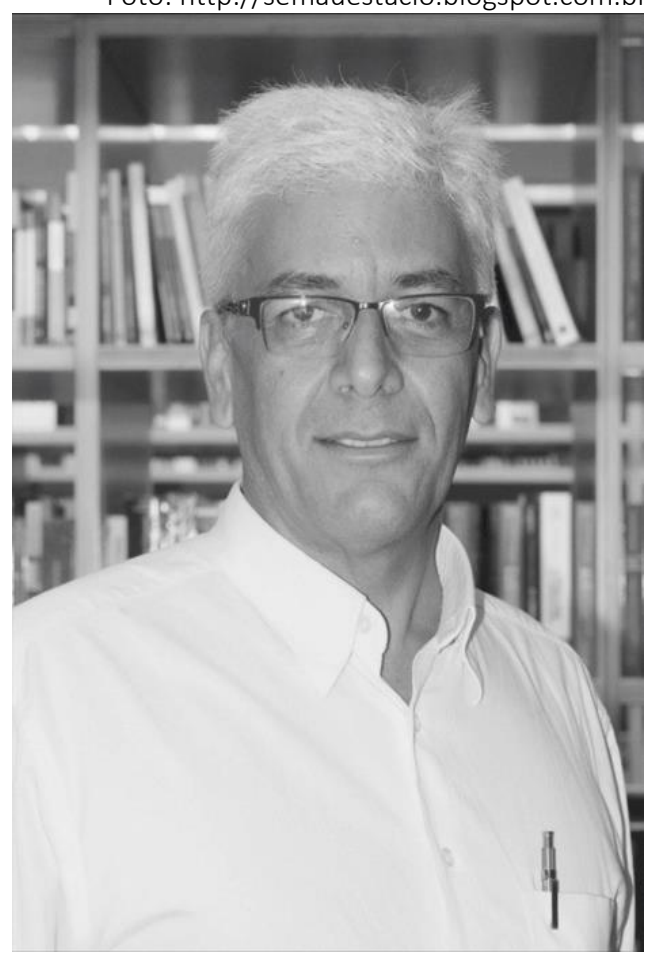

2‥ Lugar:

Paulo Henrique Paranhos, Brasília 


\section{Memorial}

O conceito de multicampi reiterou nossa primeira intenção de evitar unidades volumétricas autônomas, mas desenvolver um meticuloso trabalho de implantação que desse continuidade ao entorno imediato existente.

Nossa proposta visa reinterpretar os vetores, as linhas, a dinâmica e mais do que isto: as nuanças do lugar. Trata-se de uma apreciação que visa atender às diretrizes do "Projeto Eixo Tamanduatehy".

Ampliar a reurbanização desta faixa do território, potencializar os eixos urbanos e abrir as margens do rio resulta em desobstruir, no sentido transversal ao Eixo, o encontro da cidade com este ponto nobre da paisagem.

Mais do que evitar barreiras, propomos integrar territórios, criar permeabilidade de fluxos e cultivar uma grande massa verde; uma nova paisagem urbana e natural.

O partido resulta portanto da exploração da urbanidade arquitetônica, da sua dimensão simbólica e por sua nobreza programática conferirIhe um caráter representativo; o expressivo espaço arquitetural.

Não se trata de uma postura casual, de meras conseqüências da atual realidade mas, uma atitude de projeto que seja propositiva, que re-direcione os destinos da região.

Se a integridade do projeto extrapola a edificação e abrange, desde sua concepção, todo o contexto urbano, é notável a hierarquia programática das edificações.

A convivência do Centro Desportivo com os alojamentos nos pareceu interessante, estando ainda setorizados próximos ao entorno residencial com acessos fáceis e independentes.

As atividades acadêmicas de ensino e pesquisa em blocos interligados, no "minhocão", possibilitam a setorização adequada, facilidades administrativas, proximidades de estacionamento, flexibilidade de
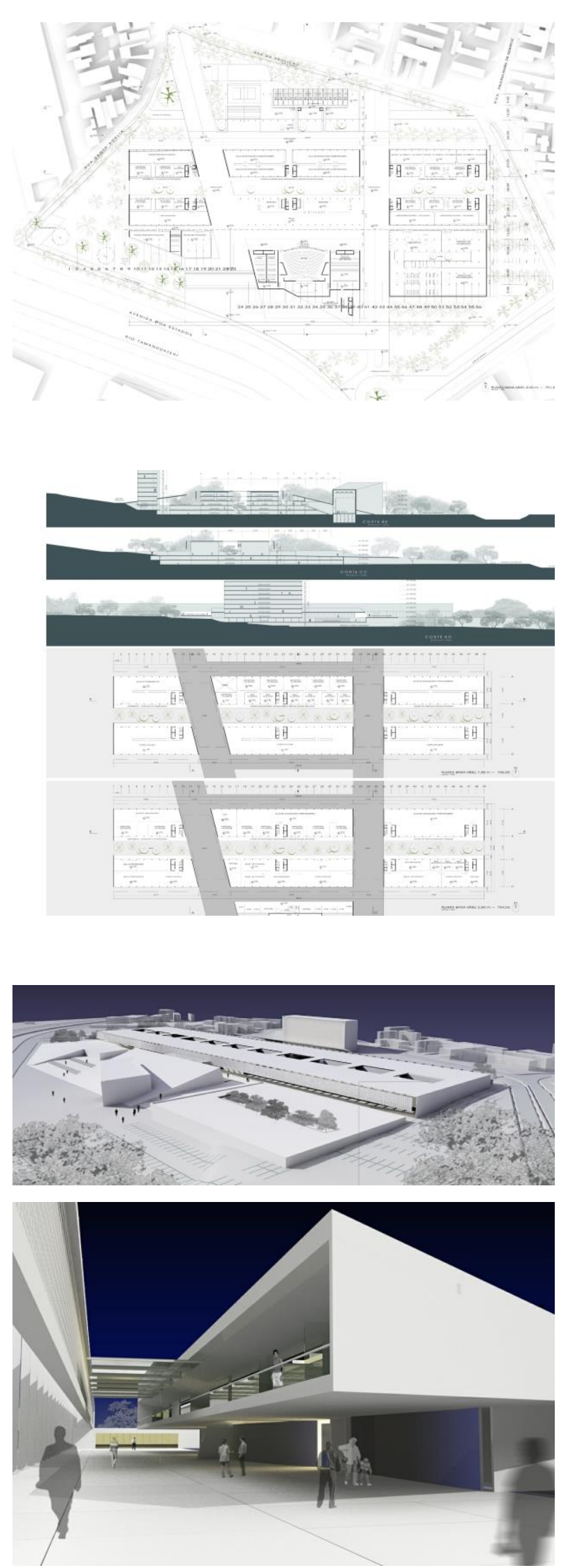

IMAGEM 51 Proposta do arquiteto Paulo Paranhos. Fonte: Tao Arquitetura 
lay-outs e fundamentalmente, razoável custo de manutenção e conforto. Fica ainda mais interessantes esta tipologia com a implantação de jardins "internos" que colaboram com a ventilação e iluminação natural "cruzada".
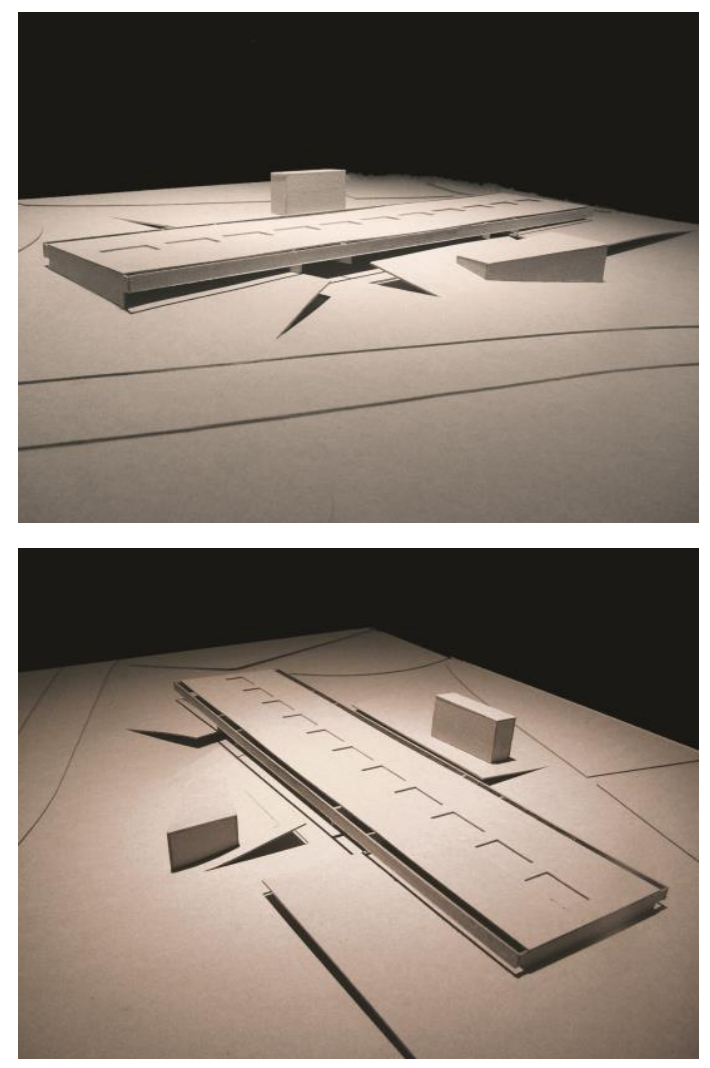

IMAGEM 52 Fotos da maquete de Implantação. Foto: Tao Arquitetura

Sendo um dado importante do programa a multiplicidade de contatos e confrontações de idéias esta pequena cidade do conhecimento lança, a partir do sítio físico existente, rampas e passarelas que conduzem o cidadão ao centro cultural, à praça da alimentação, das lojas, dos eventos, enfim, ao ponto de encontro.

Se este é o ponto focal do projeto, um tratamento volumétrico peculiar foi dado ao prédio da reitoria e prefeitura que junto ao Teatro marcam referência na grande avenida.

A intenção de viabilizar uma obra racionalizada, de custos satisfatórios e baixo custo de manutenção nos levou a adotar um sistema construtivo modular com vãos de seis metros no sentido longitudinal do conjunto, que possa ser executado em etapas, com parte da edificação em funcionamento e possibilidade de execução em estrutura metálica, concreto ou elementos pré-moldados conforme os interesses apresentados.

Talvez seja desnecessário ressaltar o posicionamento do conjunto que teve como premissa básica de implantação as determinantes físicas do desnível do terreno e da insolação.

Os cuidados relativos à topografia e sua proximidade às enchentes do rio determinaram a definição de uma cota de soleira mais alta, sem que o conjunto perdesse sua nobre característica de ampliação daquela paisagem.

A preservação do matadouro não foi totalmente descartada, mas requer umas apreciações mais detalhadas, viáveis na hora mais adequada.

Podemos dizer, portanto que resulta assim, um ponto de interesse, um parque, em fim, uma nova topografia que possa ser uma contribuição à cidade.

\section{ficha técnica}

\section{Autor}

Paulo Henrique Paranhos (arquiteto)

\section{Colaboradores}

Eder Alencar

Ana Carolina Vaz

Gabriel Bessa

Genésio Neto

Hermes Romão

Heloísa Moura 


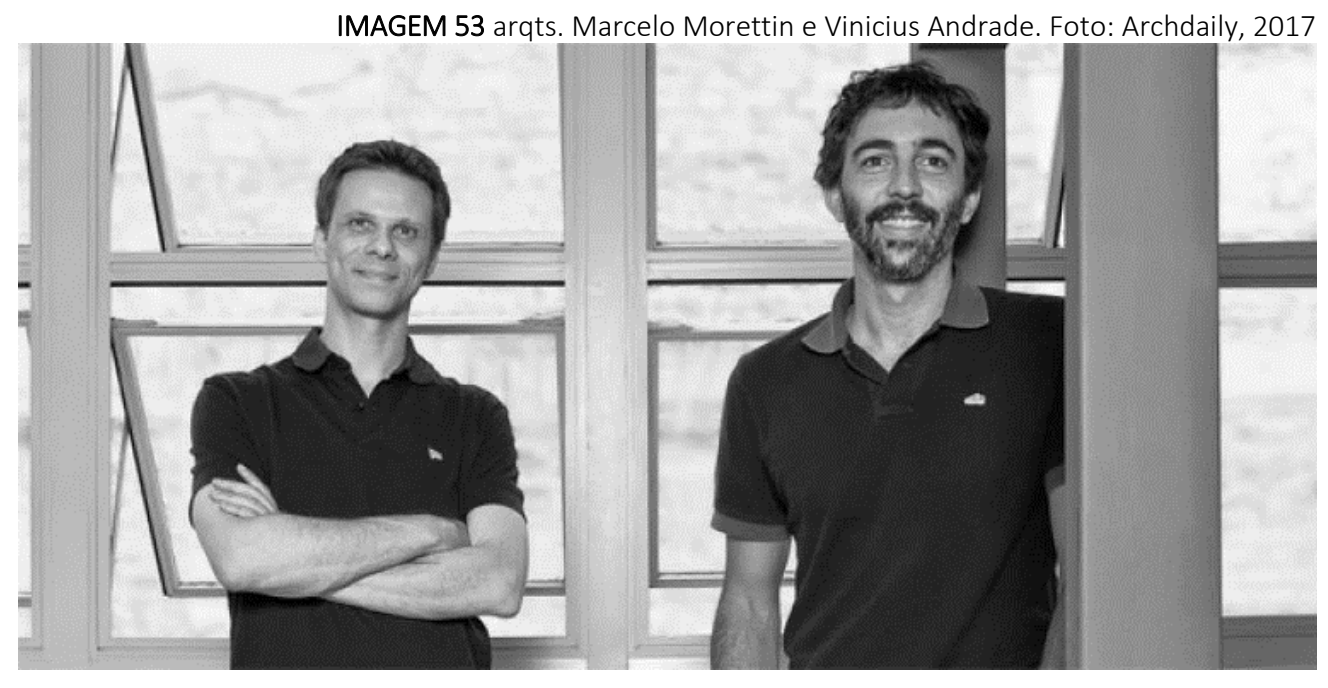

3‥ Lugar:

Andrade Morettin Arquitetos, São Paulo Vinicius Andrade Marcelo Morettin 


\section{Memorial}

O Projeto busca realizar a transição entre dois sistemas urbanos (regional e local), através do prolongamento e desdobramento dos passeios públicos no interior do lote, integrando a universidade a seu entorno.

O projeto oferece grandes superfícies equipadas (plataformas servidas por instalações prediais) que, unidas por largas rampas, formam um sistema de planos contínuos, livre para acomodar o programa com grande flexibilidade. Embora os elementos arquitetônicos estejam definidos, este projeto se apresenta como um modelo que deve ser aperfeiçoado durante o processo de projeto junto aos representantes da universidade. Neste sentido é um espaço vivo; uma arquitetura aberta.

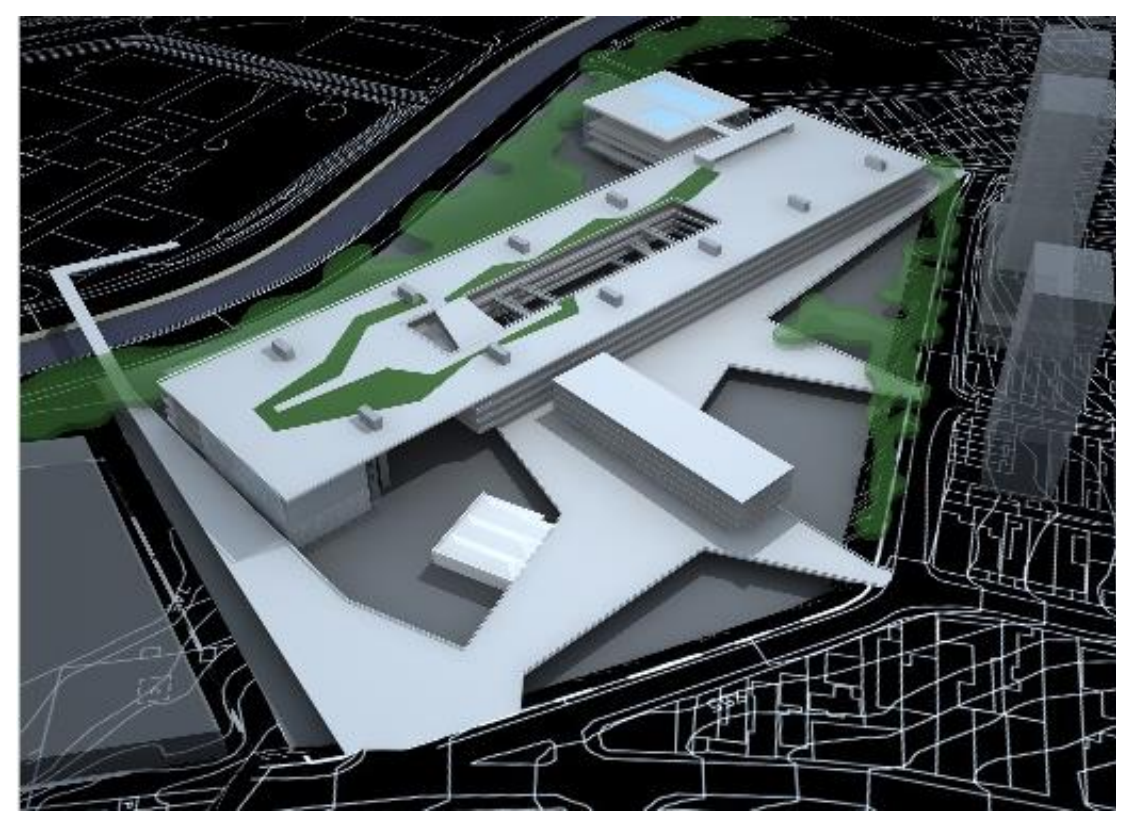

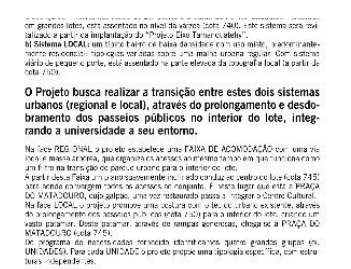
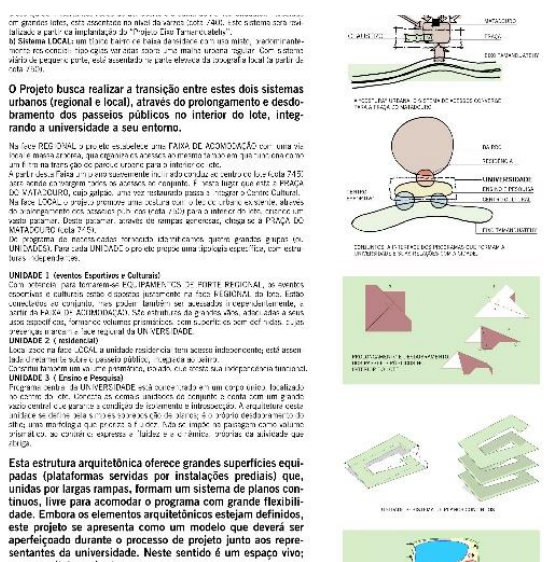

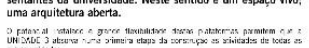

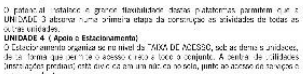
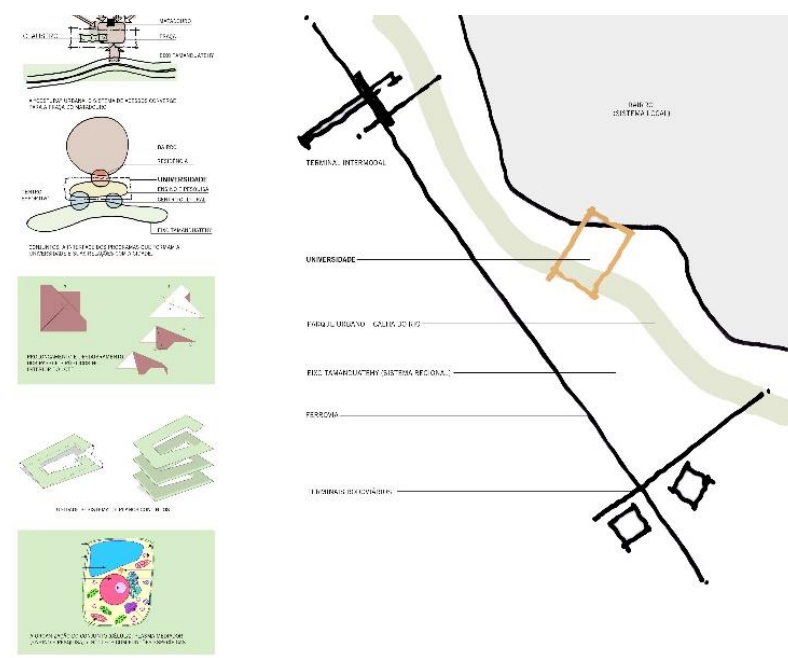

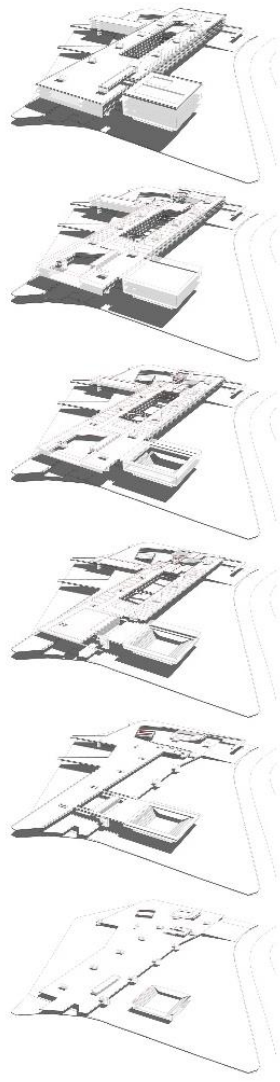




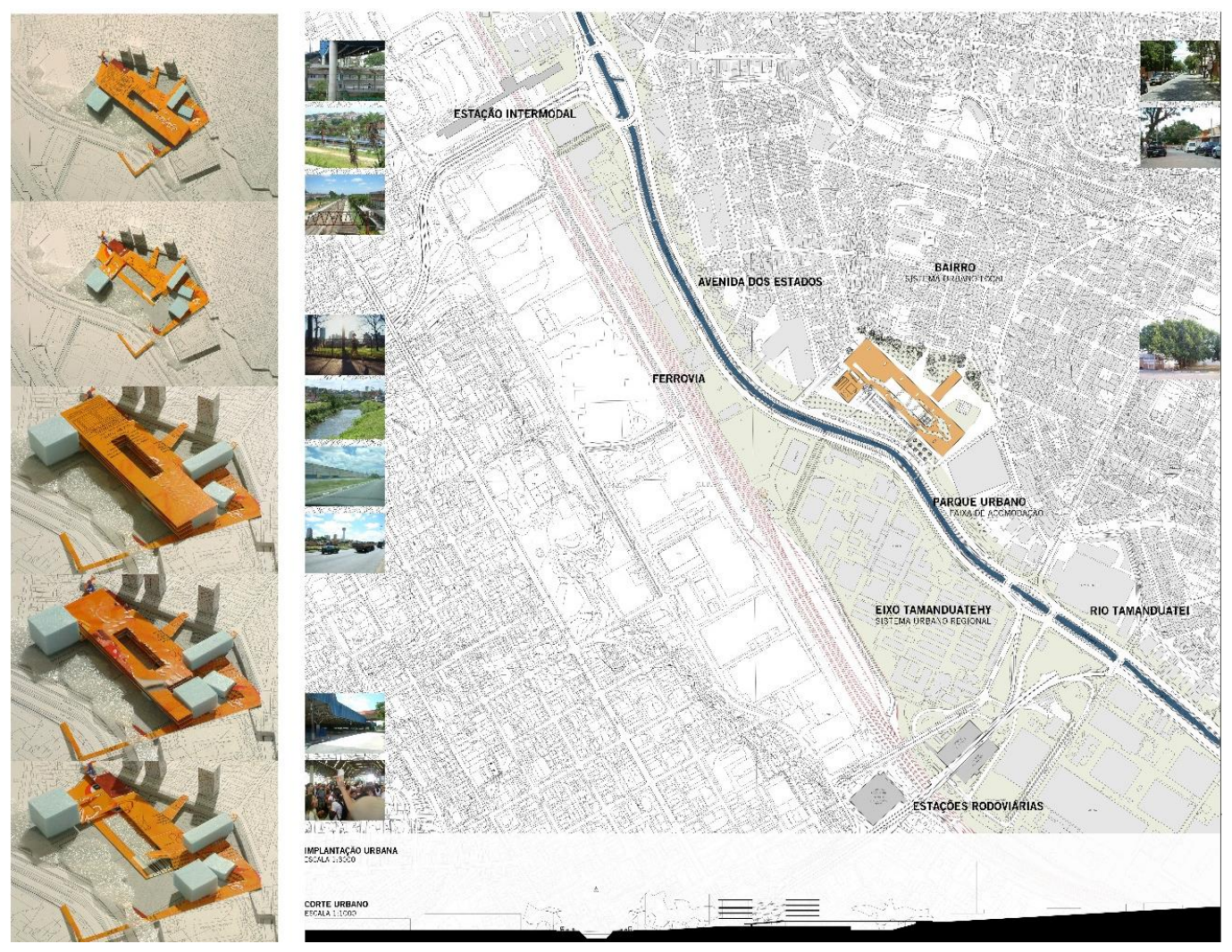

IMAGEM 55 Proposta Andrade Morettin - Painel 2.

Fonte: Andrade Morettin Arquitetos
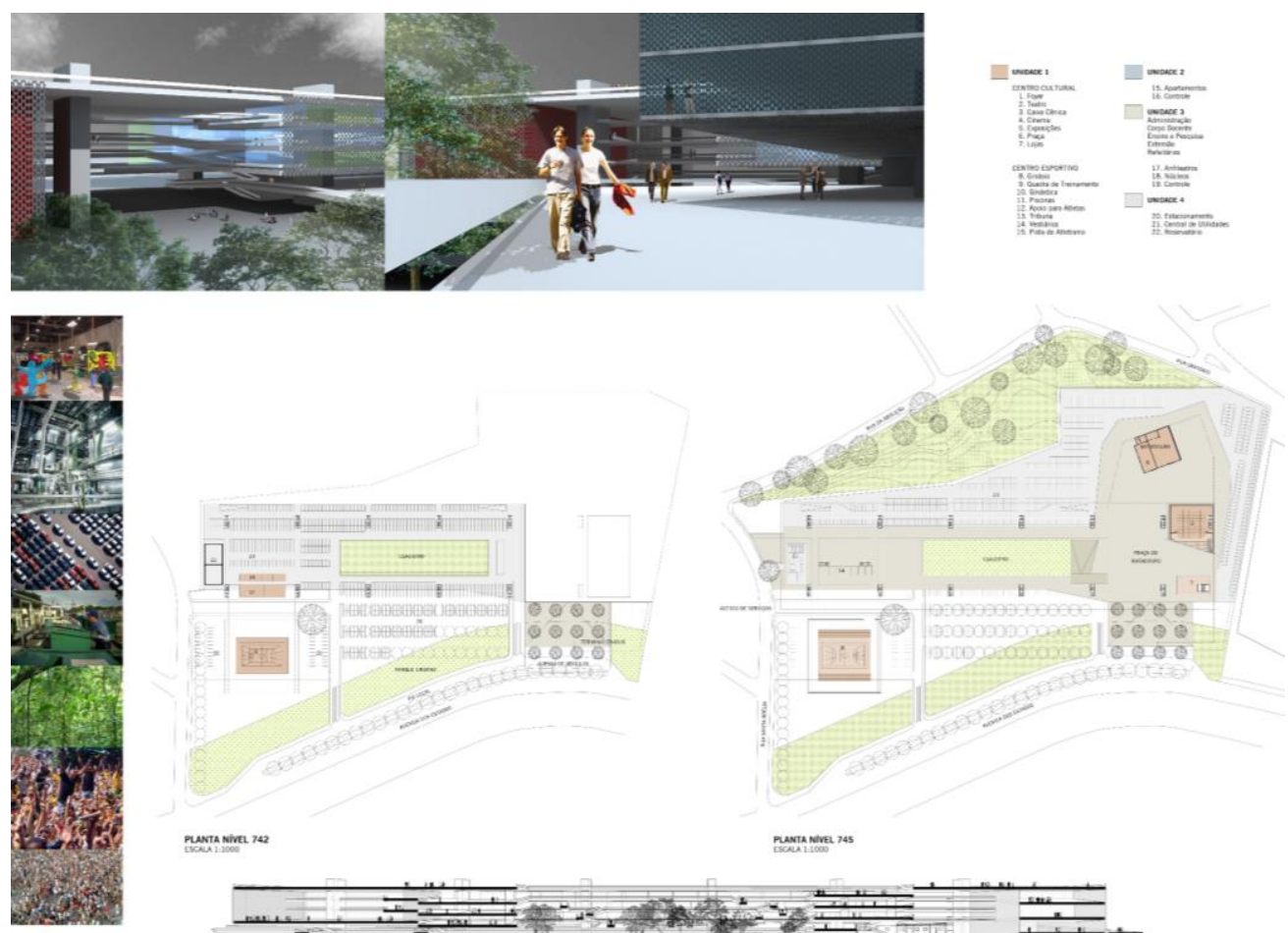

mevtantara 7 taz

persin ware 7 as

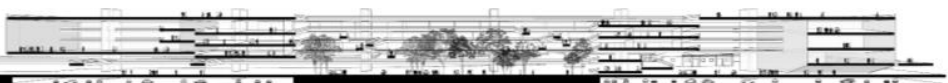

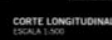

IMAGEM 56 Proposta Andrade Morettin - Painel 3.

Fonte Andrade Morettin Arquitetos 

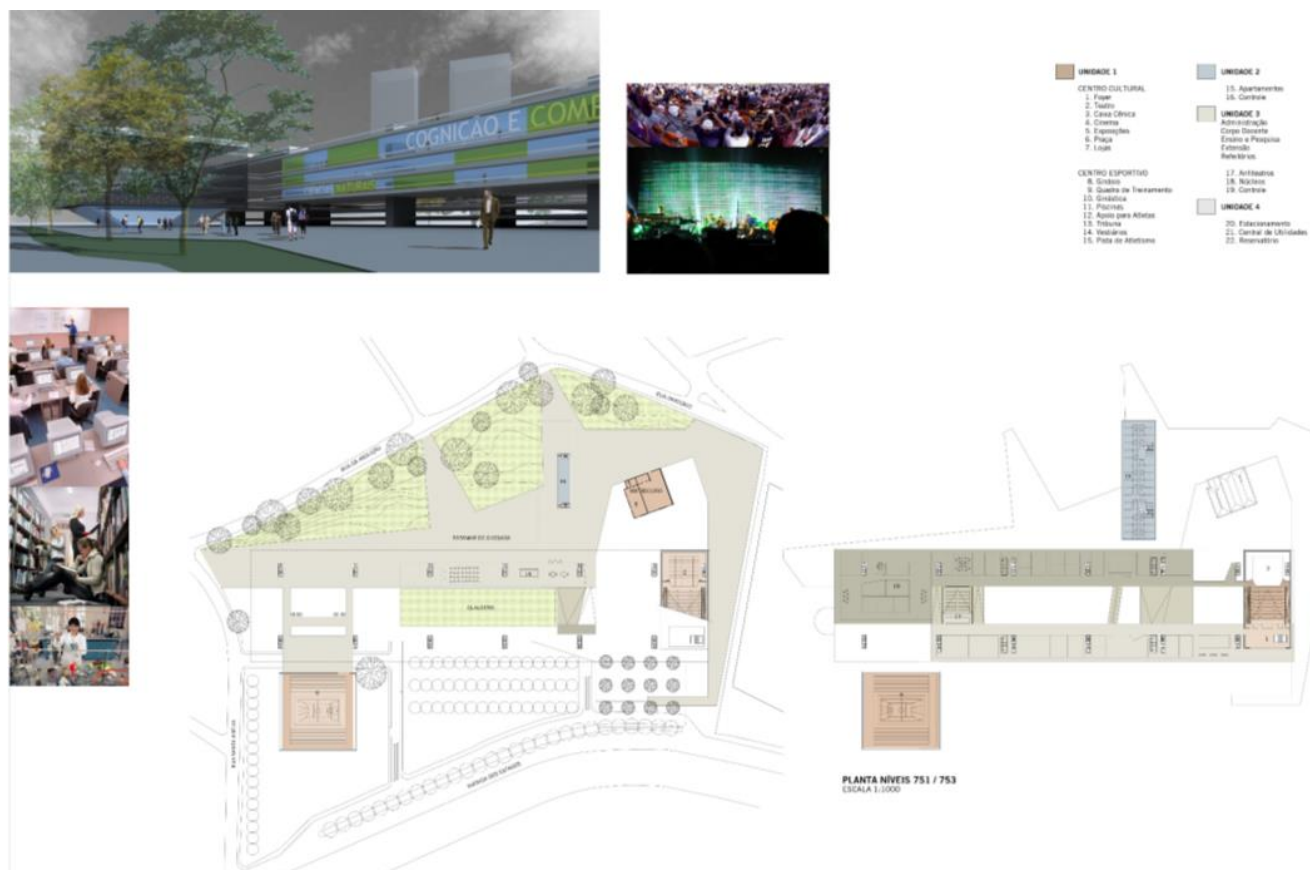

movera vima ras

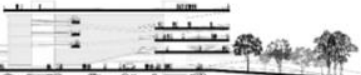

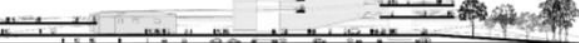

IMAGEM 57 Proposta Andrade Morettin - Painel 4.

Fonte: Andrade Morettin Arquitetos
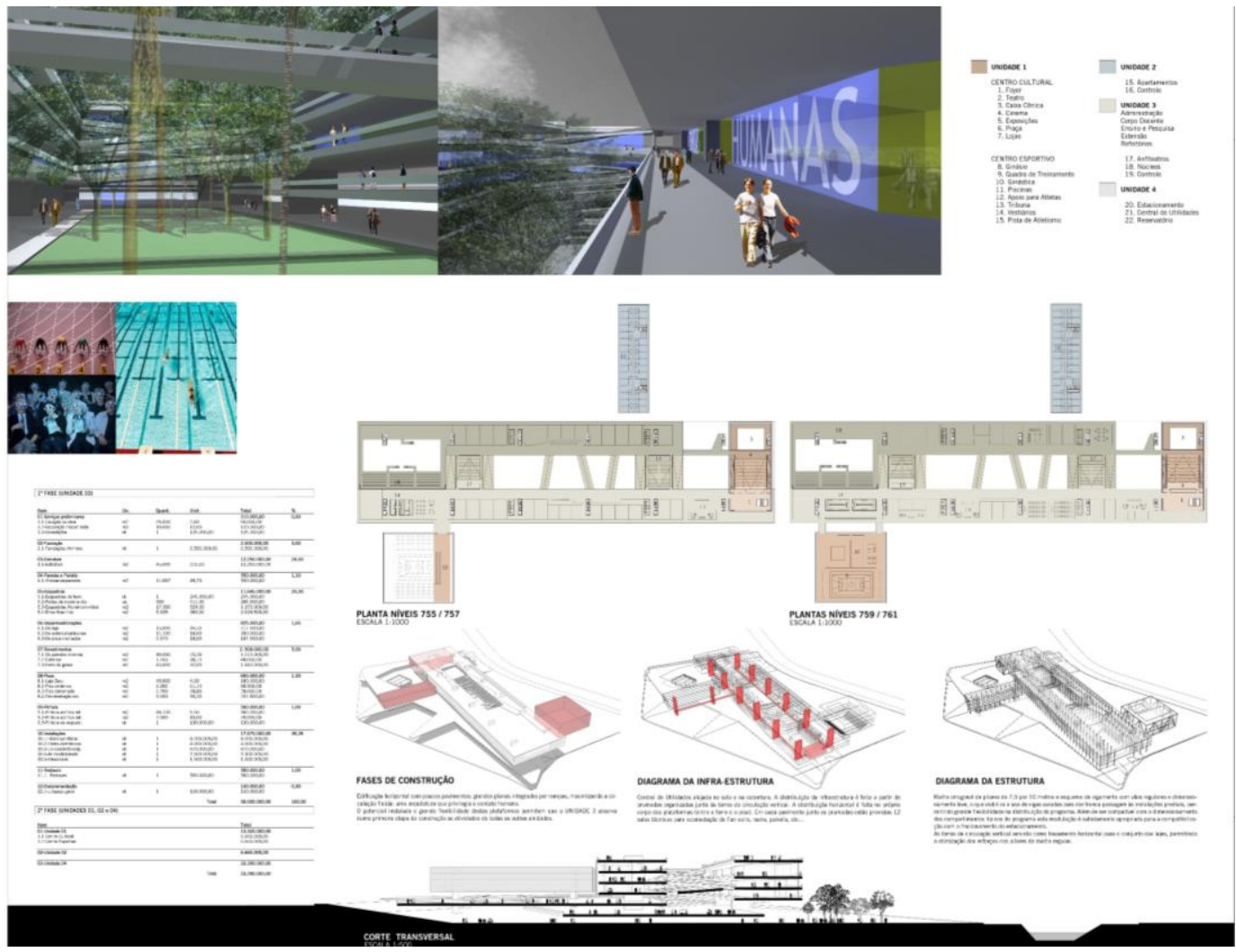

IMAGEM 58 Proposta Andrade Morettin - Painel 5.

Fonte: Andrade Morettin Arquitetos 
IMAGEM 59 Renato e Lilian Dal Pian. Foto: Dal Pian Arquitetos
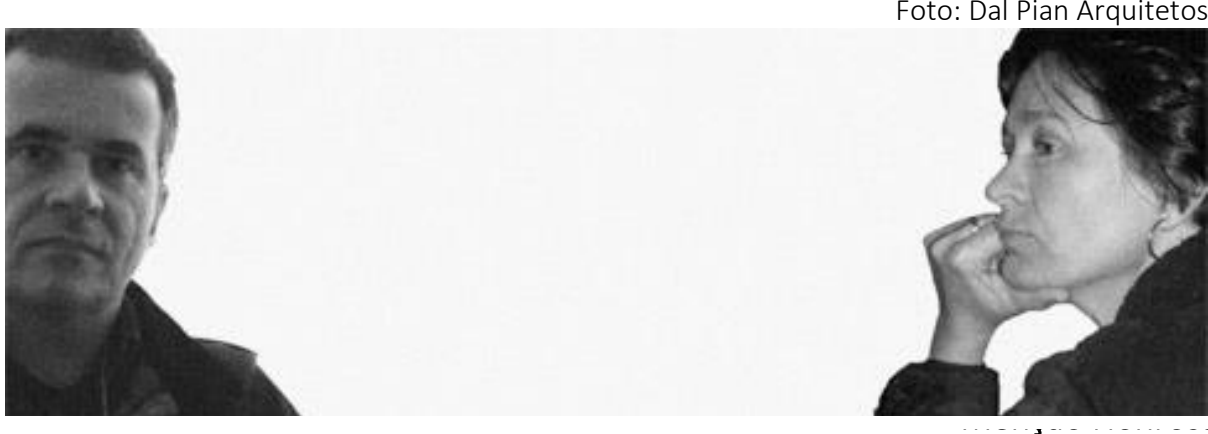

Dal Pian Arquitetos Associados, São Paulo

Lilian de Almeida Dal Pian

Renato Dal Pian 


\section{Memorial}

A Universidade como lugar de formação, conhecimento e difusão cultural deve se conformar em espaços que favoreçam o encontro e a convivência - educação é uma atividade social. O novo campus da UFABC, inserido no perímetro do macro "Projeto Eixo Tamanduatehy", se configura como instituição social e urbana que, pela sua propositura, é também pública. A prerrogativa de ser qualificador de um território fragmentado pelo rio e pela estrada de ferro conduz a um projeto que estabeleça com o tecido da cidade e suas infraestruturas de transporte, comunicação e serviços, relação direta, fluída e consequente.

\section{Partido}

O partido arquitetônico se define por quatro linhas de edifícios que, escalonados sobre duas lajes e o chão (níveis naturais), se sucedem frontais à Avenida dos Estados. Conformados ao entorno de uma Praça Congregadora e de duas Ruas Internas de circulação, abrigam as diversas atividades do campus e recebem, como parte do "Projeto Eixo Tamanduatehy", as áreas verdes do parque linear.

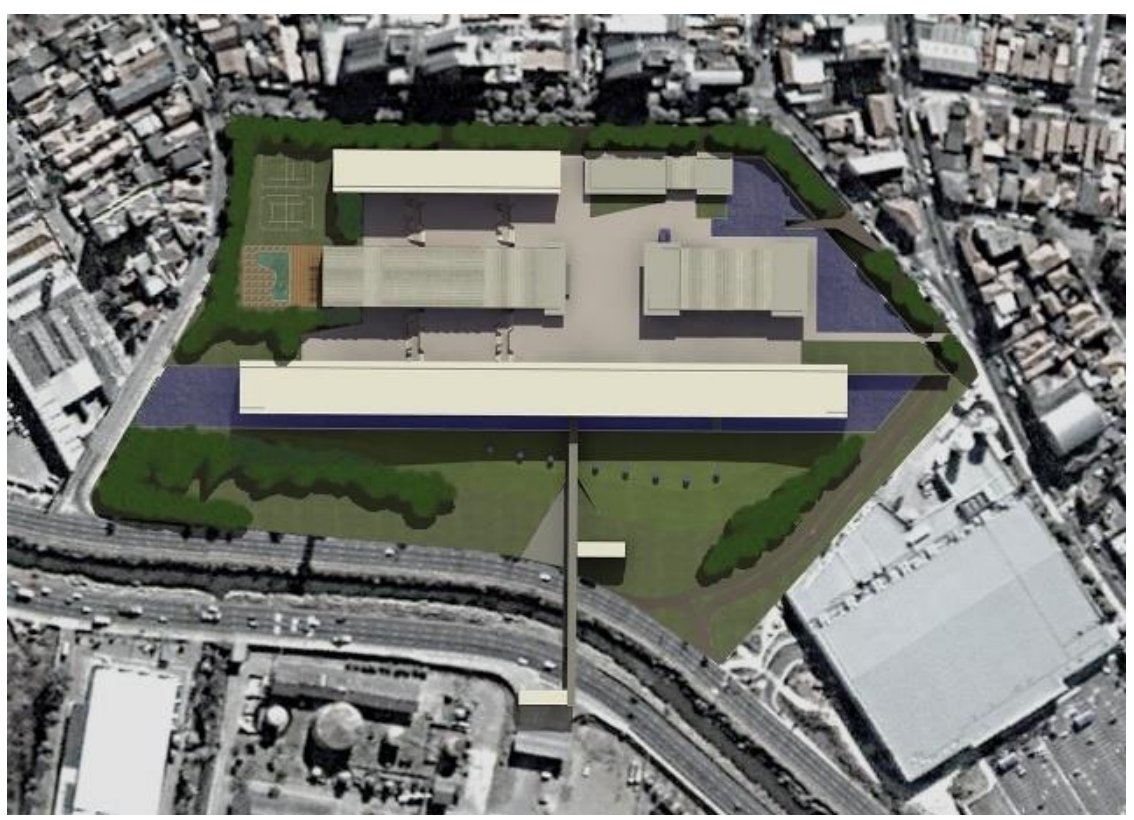

IMAGEM 60 Proposta de implantação. Fonte: Dal Pian Arquitetos

MAGEM 61 Vista da Praça Congregadora.

Fonte: Dal Pian Arquitetos

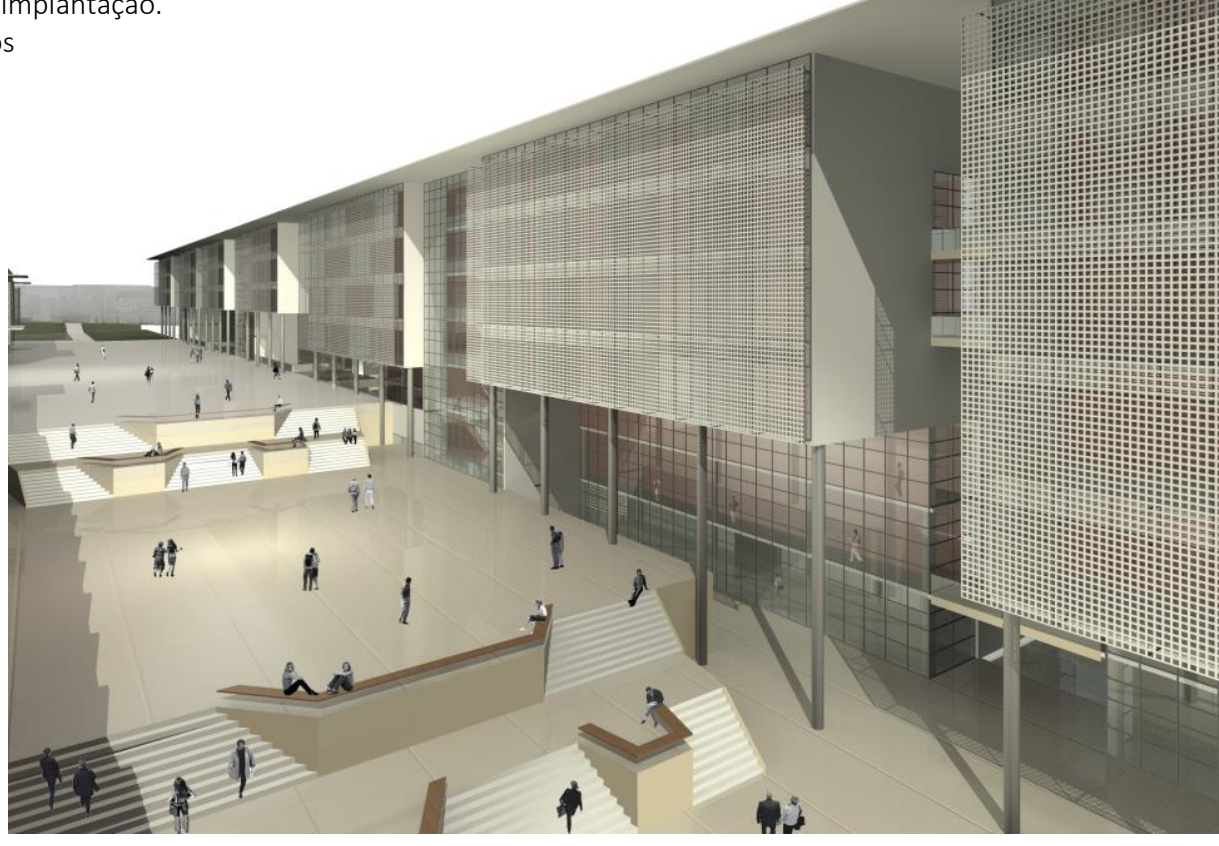




\section{Duas lajes e o chão}

Uma laje elevada, à cota 752.00, respeita o nível médio da Rua da Abolição e estabelece com essa parte da cidade uma relação visual direta. Solta dos limites do terreno, permite a manutenção e o reforço da vegetação existente nos taludes que acompanham toda a linha da rua.

Um eixo de circulação, marcado na continuidade da Rua Frei Caneca (perpendicular à Rua da Abolição), transpassa a Praça Congregadora e se transforma em generosa passarela que conecta as duas margens do Rio Tamanduateí. Ao potencializar os acessos pela Avenida dos Estados e receber os percursos de pedestres a partir da estação ferroviária e terminal de ônibus, rompe com a intransponibilidade do rio e fortalece a relação biunívoca entre o campus e a cidade.

Dessa laje receptora dos fluxos urbanos partem as duas ruas internas de circulação que conduzem, por escadarias intercaladas por nichos de bancos, a uma segunda laje, à cota 748.00 e, na continuidade, aos níveis naturais do terreno (cota base 744.00). Esses percursos sequenciais permitem os acessos, por níveis variados, aos edifícios que conformam o campus.

Os estacionamentos, sob essas duas lajes, têm comunicação setorial e direta com edifícios. Sem causar impacto visual ao

IMAGEM 62 Imagens da Proposta
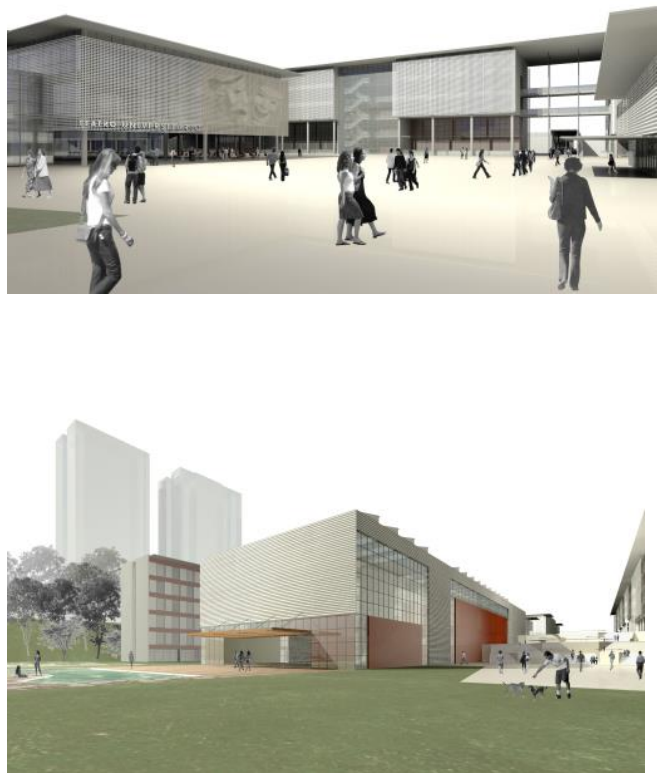

conjunto edificado, respondem às necessidades de vagas requeridas.

Quatro linhas de edifícios

Linha 1 - Biblioteca/auditórios

Frontal à Avenida dos Estados um corpo semienterrado abriga o Núcleo de Informação/Biblioteca e os Auditórios. Sua cobertura em laje-jardim permite que o Parque Linear prolongue suas áreas verdes.

\section{Linha 2 - Docentes/discentes}

Faceando o espelho d'água, uma sequência de quatro edifícios abriga os espaços para docentes e as atividades de ensino, pesquisa e extensão.

\section{convivência, esportes}

Linha 3 - Administração, cultura,

$\mathrm{Na}$ sequência paralela dos edifícios acadêmicos, entre as duas ruas internas e definindo os espaços da Praça Congregadora, se conformam dois edifícios:

1. Edifício do Teatro, Convivência e Administração

2. Edifício dos Cinemas e Esportes

A piscina externa de recreação e as quadras descobertas, envolvidas por arborização de sombreamento, concluem o centro esportivo da universidade.

\section{Linha 4 - Alojamentos/refeitórios}

Frontais à Rua da Abolição, os refeitórios e os alojamentos para estudantes concluem a sequência de edifícios do campus.
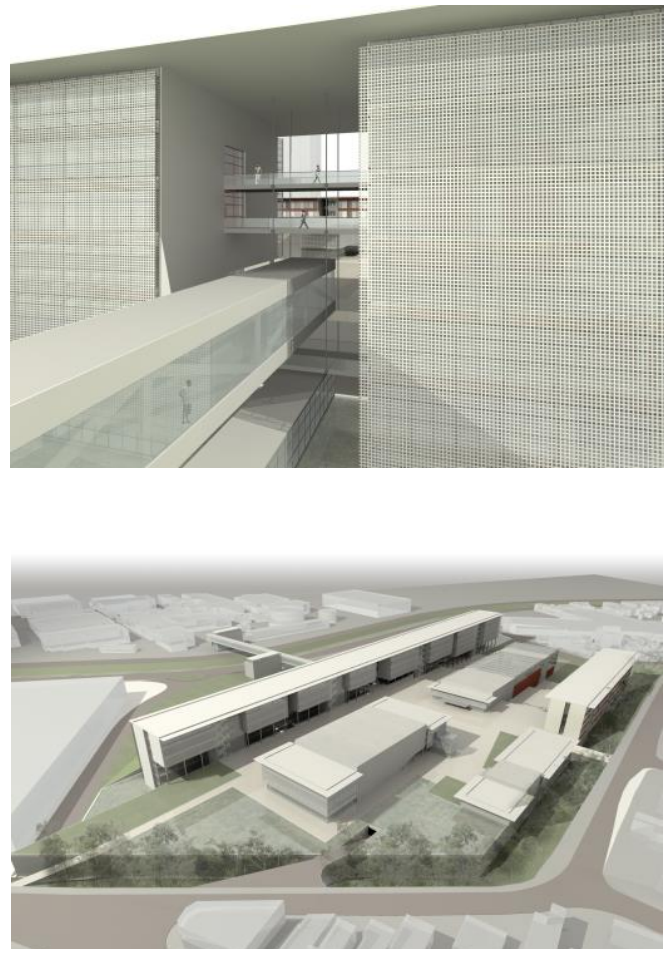
Menção Honrosa:

CasaCin.co Arquitetura, Curitiba

Ricardo Alberti

Boris Madsen Cunha 
Memorial

Introdução

A proposta para a UFABC apoia-se nos seguintes pontos, que consideramos fundamentais:

Integrar o campus ao entorno imediato, revertendo a situação de enclave urbano na qual a área se encontra atualmente;

Organizar os grandes fluxos de usuários que transitarão diariamente pelo campus, dando privilégio ao pedestre sobre o automóvel;

Criar uma paisagem rica, composta por diversos espaços de encontro e de animação;

Mitigar o impacto físico da implantação do Campus, criando áreas de amenização nas suas interfaces com a malha urbana;

Empregar tecnologias de construção de ótimos desempenho e relação custo-benefício;

Empregar soluções de projeto que permitam a acessibilidade universal dos usuários.

\section{Concepção gera}

Partindo do pressuposto da necessidade de reintegração da área à malha urbana face às complexidades adjacentes (Rodovia dos Estados, Rio Tamanduateí), e da opção pela preservação e reciclagem da construção principal do antigo Matadouro Municipal, propomos a criação de dois grandes eixos organizadores do projeto: norte-sul e leste-oeste. O primeiro conecta as porções da malha urbana imediatamente ao norte e ao sul da área, criando para o cidadão uma alternativa de circulação peatonal pública completamente livre de obstáculos; materializa-se pela proposição de uma passarela suspensa que atravessa todo o Campus. O segundo eixo é definido pela análise da posição do Matadouro e da sua desejável integração com um grande espaço de convívio no núcleo do Campus. Dessa maneira, o eixo setoriza a área em duas porções: os Setores de Ensino/Institucional (ao norte) e de Convívio/Apoio (ao sul), e toma corpo através de uma grande marquise que interliga o Campus de leste a oeste.

IMAGEM 63 Implantação, Perspectiva e Cortes. Fonte: site Vitruvius
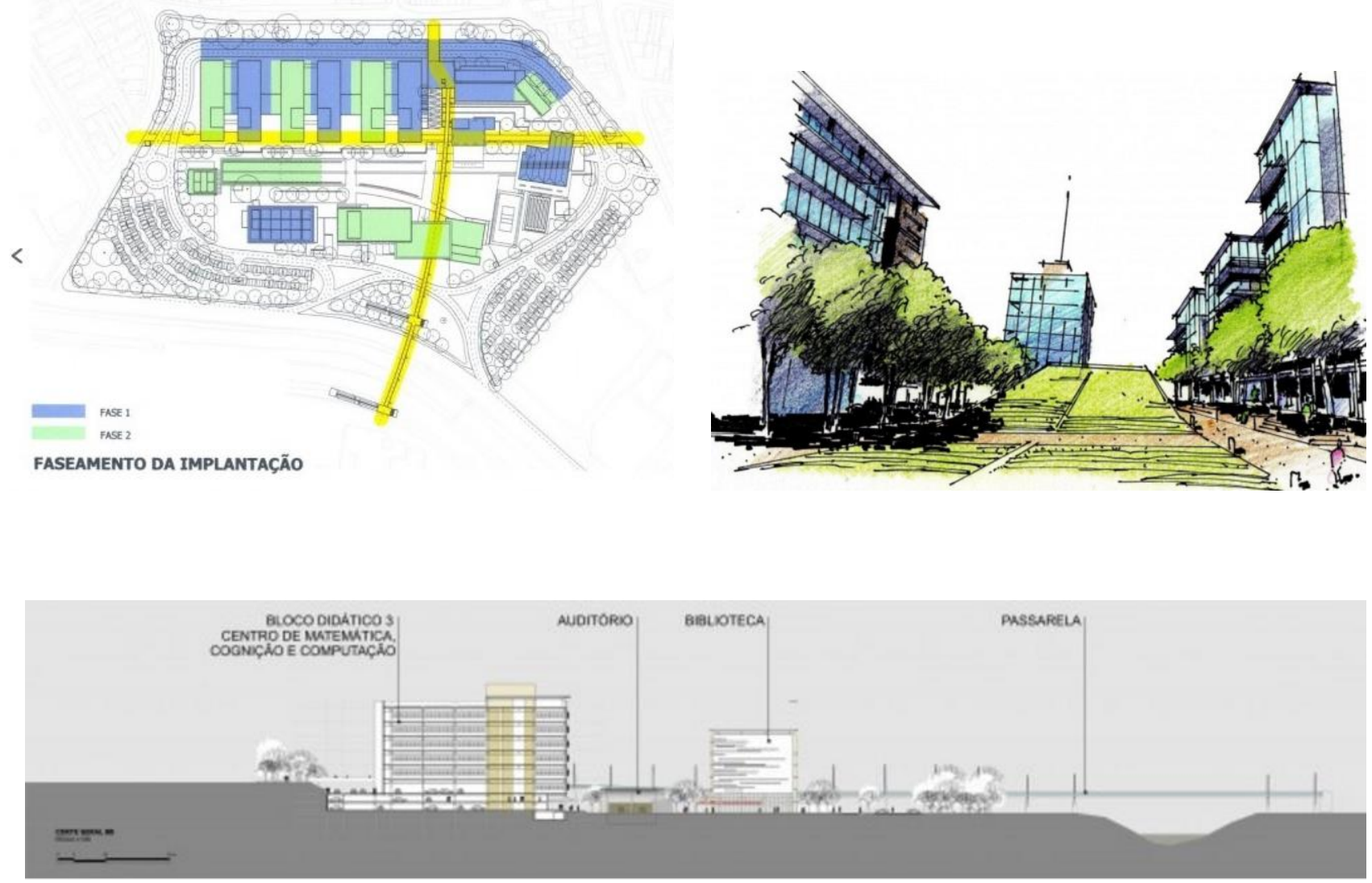
O júri destacou, no projeto vencedor, a forte imagem urbana e uma implantação distinta das outras propostas, permitindo uma conexão com o bairro mais efetiva. A criação de praças e um partido arquitetônico com boas possibilidades de crescimento foram considerados de forma destacada. As ressalvas ficaram para o acesso ao campus, a localização da moradia estudantil e as prumadas de circulação verticais.

A proposta de Paulo Paranhos mostrou uma compreensão do papel da UFABC como uma proposta renovadora do ensino superior, resgatando o princípio do partido arquitetônico tal qual fora a UnB nos anos 1960, na qual é o edifício que viabiliza a integração pedagógica e territorial. Não manteve o edifício do Matadouro Municipal.

A proposta de Andrade Morettin se utiliza do edifício para fazer uma transição mais harmoniosa entre todos os elementos do entorno, inclusive o Matadouro, onde propõe uma praça com o mesmo nome. Interessante observar a solução dada para as fases da obra e para a distribuição da infraestrutura.

As menções honrosas têm propostas de implantação similares, ao criar eixos transversais e longitudinais, porém destacando-se a qualidade urbanística da praça criada pelo escritório Dal Pian Arquitetos Associados.

De fato, a proposta vencedora foi a que melhor traduziu as solicitações do edital, demonstrando uma compreensão ímpar daquilo que foi solicitado: um equipamento de destaque na área do Eixo Tamanduatehy, que fosse elemento integralizante dos diversos elementos daquela paisagem e abarcasse um projeto pedagógico diferenciado com forte caráter de inclusão social.

\subsection{Entrevista com Sandra Llovet e Claudio Libeskind}

Em 18 de outubro de 2012, como parte da pesquisa sobre universidades para a disciplina de pós-graduação Arquitetura Contemporânea Paulista, realizei uma entrevista com os responsáveis pelo o escritório LibeskindLlovett. Para esta entrevista, foi elaborado um roteiro de questões, seguido informalmente, e alguns trechos das respostas são apresentados a seguir:

Seu projeto foi escolhido por representar, em sua expressão arquitetônica, os anseios da universidade do século 21. Este tema foi abordado na concepção do projeto? Qual foi o partido? 
LibeskindLlovet: Não foi nossa preocupação projetar uma Universidade que arquitetura representasse o século 21, mas sim um enorme desejo que a nossa arquitetura demonstrasse que Universidade pertence à cidade, que a cidade usufruísse dos espaços abertos e voltados a ela, como por exemplo a praça do sol, na parte leste do terreno. [...]. Para a implantação dos edifícios foi utilizado um paralelismo com a ferrovia a partir de uma tangente da curva da Avenida dos Estados. Essa tangente formou uma diagonal no terreno, cortando-o em duas partes e tornando-se um forte eixo na composição do conjunto, determinando o acesso principal do conjunto, no qual os veículos acessam por baixo, para o estacionamento, e os alunos caminham por cima, pela rampa de acesso ao Bloco A. Acredito que tais elementos foram determinantes para que este projeto fosse considerado vencedor.

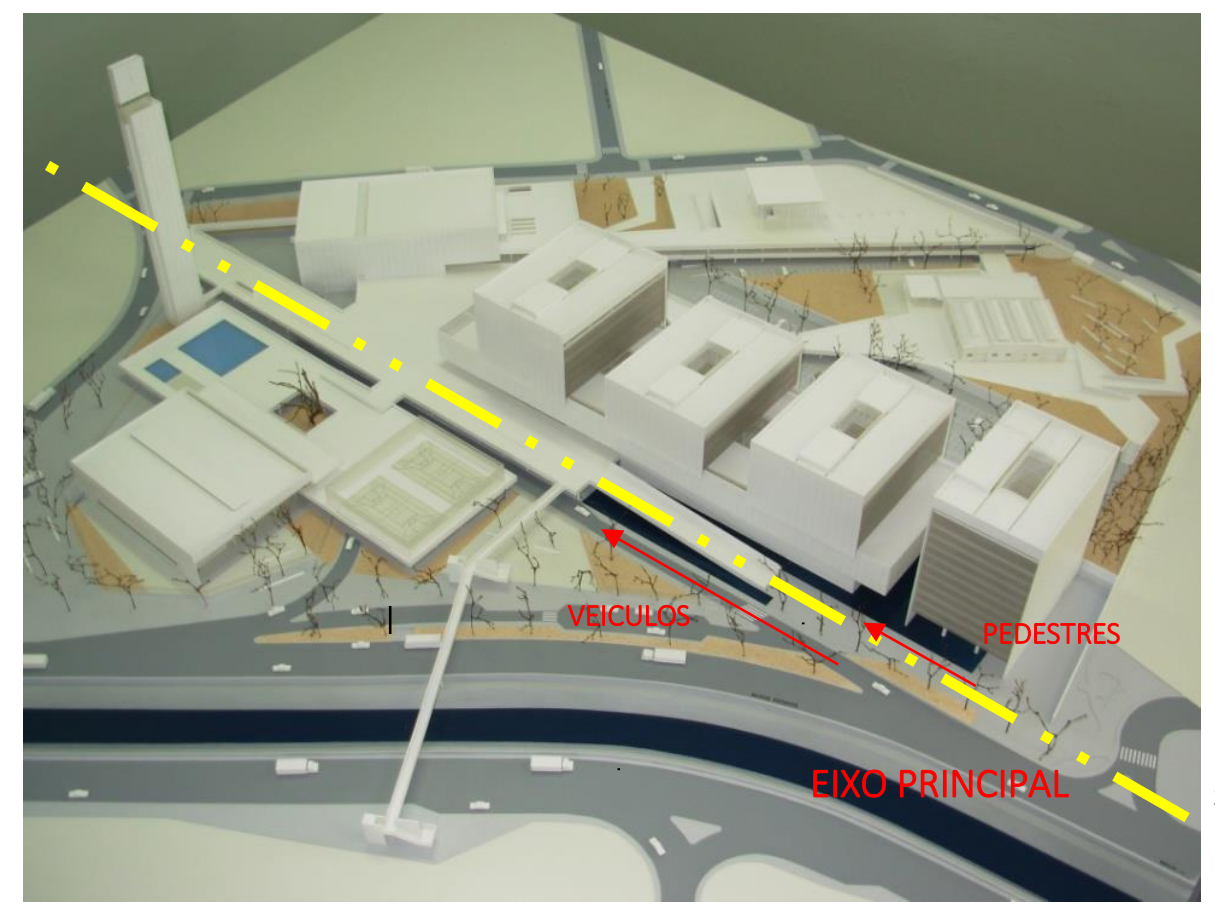

IMAGEM 64 Maquete do campus Santo André e o conceito do projeto. Fonte: UFABC

Dado que a preservação do matadouro era facultativa, por que vocês o preservaram? Essa preservação foi exitosa ou ainda está em curso?

LibeskindLlovet: Para a intervenção no matadouro, fizemos uma associação matadouro = alimento e refeitório. Porém foi difícil achar as plantas originais. Sempre achamos que o edifício existente se adequava ao nosso projeto. Nunca o vimos como um incômodo e tentamos integrá-lo da melhor forma possível na implantação. A cozinha seria o elemento novo que se agregou ao edifício existente. Contudo, a recuperação foi um problema para a construtora e o resultado foi aquém do esperado. Entendemos também que enquanto os espaços externos não forem concluídos, com o paisagismo, inclusive, o conjunto deixará de ter vida. Nosso olhar (dos arquitetos) é muito mais crítico que o dos usuários. 

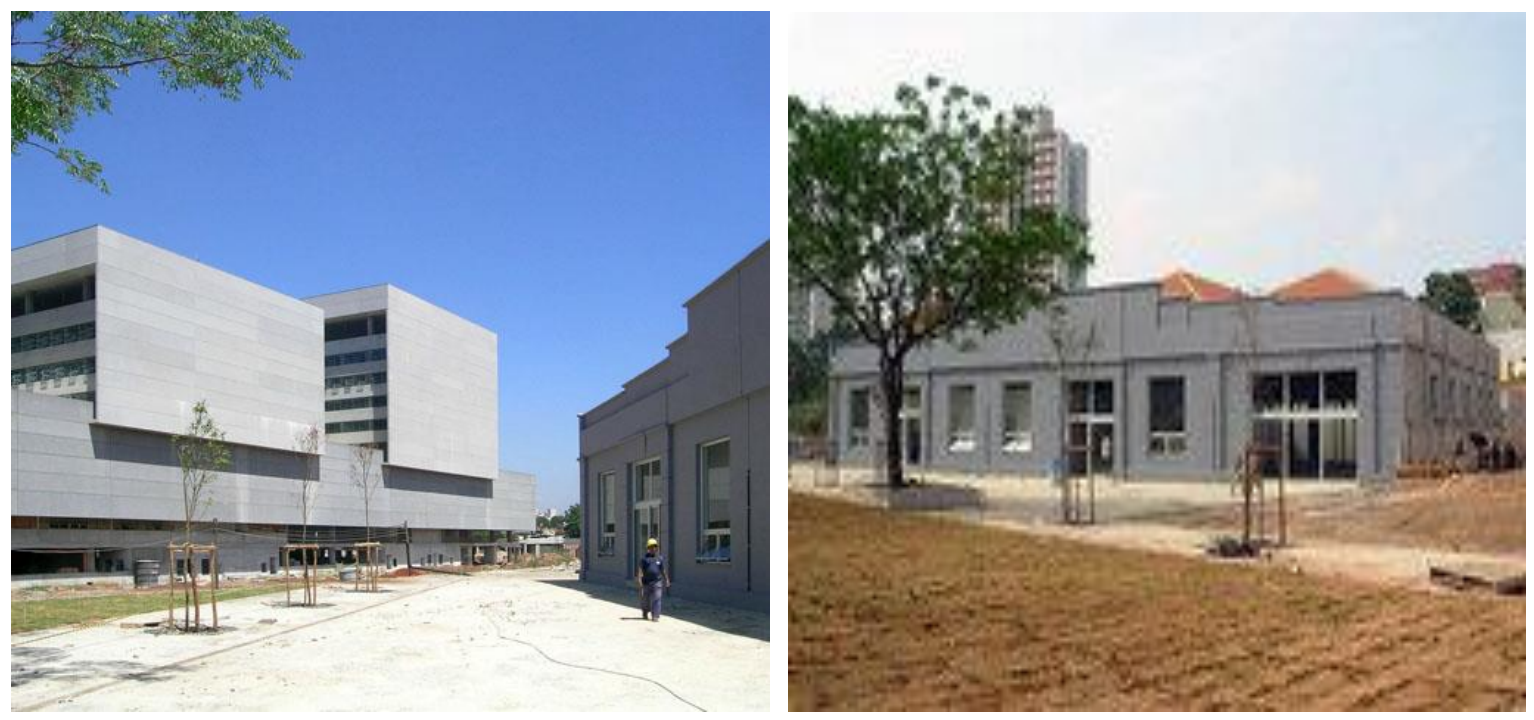

IMAGEM 65 Fotos da obra - Bloco A e refeitório, antigo Matadouro Municipal.

Fonte: UFABC, 2012

Considerando o que especificava o Edital do Concurso, vocês creem que o objetivo foi atingido, ou seja, o programa pedagógico foi traduzido pelo projeto arquitetônico? Quais elementos considerados para chegar àquele resultado?

LibeskindLlovet: As intenções iniciais do partido diferenciaram nosso projeto: optamos pela verticalização dos edifícios para liberar mais área e espaços abertos no nível de acesso de pedestre... houve uma polêmica sobre a altura dos prédios, pois os prédios tinham alturas diferentes. O programa para de cada edifício era diferente. De acordo com o edital, no programa pedagógico, haveria um embasamento comum para todas as matérias e as torres seriam para cada área especifica (Edifício da engenharia, edifício da matemática e cognição, edifício das ciências naturais) [...] para alguns jurados a diferença das alturas (do Bloco A) causou certo estranhamento, mas entendo que deu um grande movimento à fachada, e fomos buscar inspiração na arquitetura moderna.

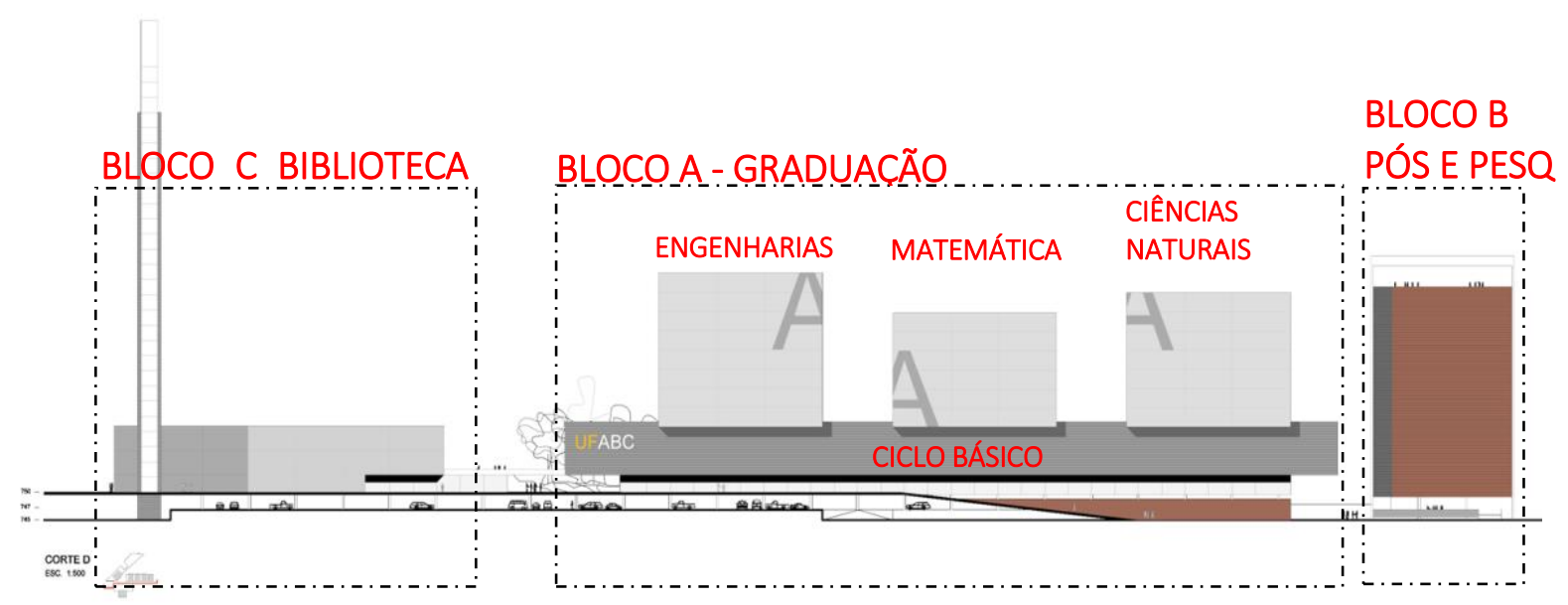

IMAGEM 66 Diagrama Projeto Arquitetônico X Projeto Pedagógico 
Embora o campus ainda não esteja completamente consolidado, gostaria de conhecer o ponto de vista dos autores do projeto sobre o processo de implantação da UFABC.

LibeskindLlovet: Nós aqui no escritório apelidamos a obra de "catedral" (em referência a Sagrada Família, Barcelona) pois a obra nunca termina... e nos incomodou não sermos contratados para o acompanhamento. Como a Universidade é recente, muitas mudanças foram feitas para adequar os espaços que a Instituição demanda.

Quando ganhamos o concurso, havia uma equipe muito pequena, lideradas pelo Reitor. Com o passar do tempo, ampliou-se o número de alunos, professores, funcionários e houve mudanças na obra, dada a dinâmica da Universidade. Nossa equipe manteve-se afastada das discussões de adequação dos espaços no decorrer da obra. O projeto, de grande porte, com programa extenso, foi executado muito rápido. [...]. No entanto, volumetricamente, o projeto está consolidado. Esperamos que a Universidade, nas suas políticas de expansão, preserve os espaços abertos e semiabertos que foram projetados como a praça (do sol), praça da torre do relógio, na porção oeste do terreno.

Como tais espaços ainda não foram construídos, entendemos que é de suma importância mantê-lo. O Bloco Cultural tem acesso livre pelos dois níveis (subsolo e térreo). Os gradis foram projetados de forma a que se integrem ao paisagismo e não apareçam. No processo de implantação, através da obra, muita coisa ainda não foi feita, o que é preocupante, pois há boas soluções de segurança, que preservam a possibilidade dos espaços aberto e semiaberto, e que ainda não foram aplicadas.

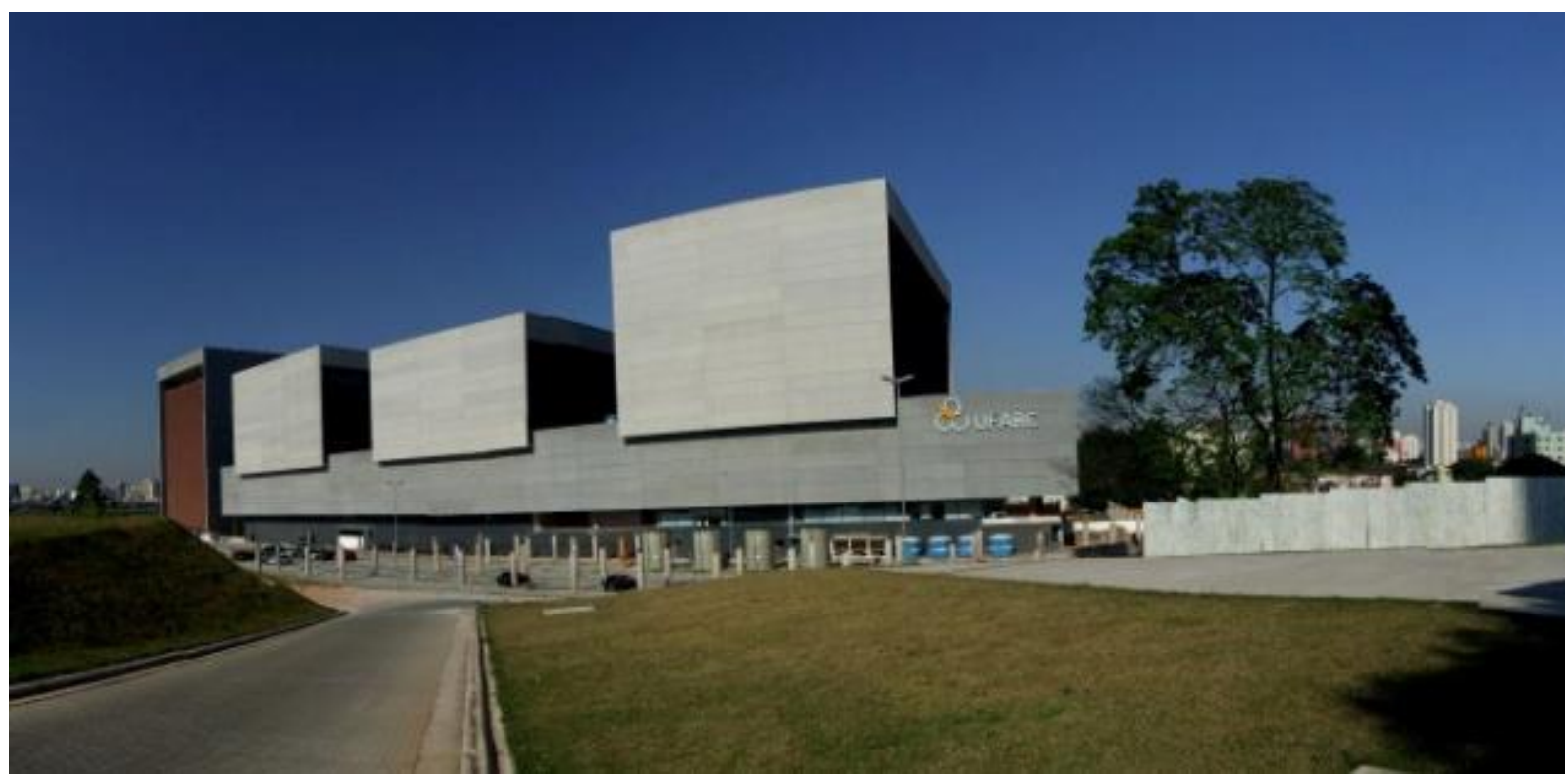

IMAGEM 67 Vista Bloco A e Bloco B.

Fonte: UFABC,2012 


\subsection{A expansão multicampi: o campus São Bernardo}

Conforme visto no subcapítulo 1.4, em 2007, o MEC começou a implantar a segunda fase do programa REUNI. Em consonância, a UFABC, como prioridade do governo, dava prosseguimento ao plano de expansão, cuja meta era atender 20 mil estudantes, visando a estender seus campi para outras cidades do ABC Paulista, considerando seu caráter multicampi

Art. 2ㅇA A UABC terá por objetivo ministrar educação superior, desenvolver pesquisa nas diversas áreas do conhecimento e promover a extensão universitária, caracterizando sua inserção regional mediante atuação multicampi na região do ABC paulista. (BRASIL, 2005)

Encontrar uma área de grandes dimensões e de fácil acesso para o novo campus em uma região metropolitana densamente edificada mostrou-se, de imediato, uma tarefa difícil. A experiência acumulada no campus Santo André fazia considerá-lo um terreno pequeno $\left(72.000 \mathrm{~m}^{2}\right)$ e demasiado urbano. Alguns dirigentes entendiam que a urbanidade do terreno do campus Santo André criara um campo de tensões que desviara os jovens estudantes cientistas do caminho do conhecimento. O apelo à vida social e urbana representava uma condição adversa ao aprendizado da ciência - conforme entendimento de alguns dirigentes da UFABC.

Durante 3 meses, equipes do MEC e da UFABC buscaram áreas em torno de 100.000 $\mathrm{m}^{2}$, públicas ou particulares, passíveis de compra para a criação do novo campus. Foram selecionadas 10 áreas, apontadas na imagem abaixo, mostrando distância entre o campus Santo André (1) e os outros terrenos. As áreas de interesse 2 e 3 situam-se no município de Mauá, as áreas 8 e 9 pertencem ao município de Santo André, na margem da represa Billings, onde se localiza a Vila de Paranapiacaba. As áreas 4,5,6,7 e 10 pertencem ao munícipio de São Bernardo do Campo.

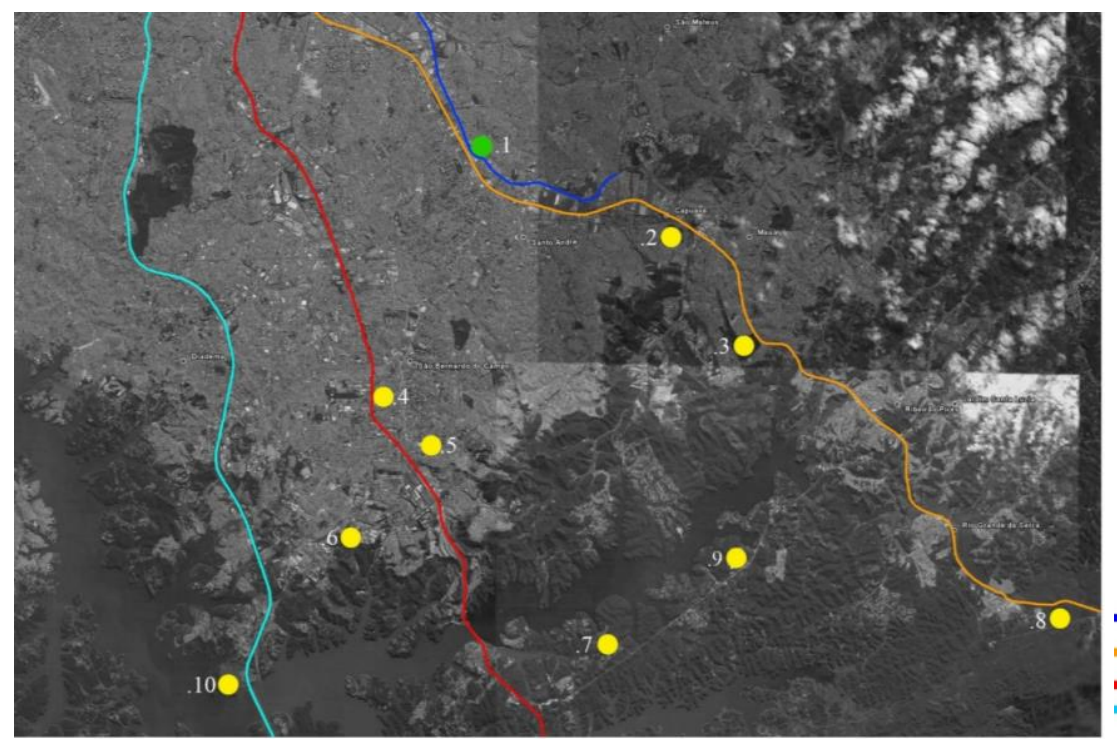


O professor Luiz Bevilacqua, que se tornou reitor pro tempore após a saída do professor Hermano Tavares, em 2006, tinha especial apreço pela Vila de Paranapiacaba, onde sempre vislumbrou a ocupação da pequena vila histórica pela Universidade, em um desenho similar ao de Cambridge, Oxford ou Heidelberg, definidas como um modelo simbiótico entre cidade e universidade. Porém, a decisão sobre a área a ser utilizada coube ao ministro Fernando Haddad e ao presidente Luís Inácio Lula da Silva, que optaram pela área 4 (imagem 64). O MEC e a UFABC adquiriram o terreno localizado na altura do Km 17 da marginal esquerda da Via Anchieta, antes pertencente à Prefeitura do Município de São Bernardo do Campo, com 120.349, $73 \mathrm{~m}^{2}$, pelo valor de $\mathrm{R} \$ 50.000 .000,00^{46}$, distando 4 quilômetros do campus Santo André.

O terreno é parte de uma gleba de grandes proporções, inserido em tecido urbano já consolidado, entre a Via Anchieta, a Oeste, e importante via do município, Avenida Kennedy, a Leste. Portanto, uma região bastante valorizada e bem atendida por transporte municipal e intermunicipal, ainda com previsão da construção de um complexo viário na porção sul, interligando os bairros através do prolongamento da Av. São Paulo (imagem 65) e de um túnel em nível abaixo da Via Anchieta, conforme Plano de Transportes Urbanos (PTU) da PMSBC.

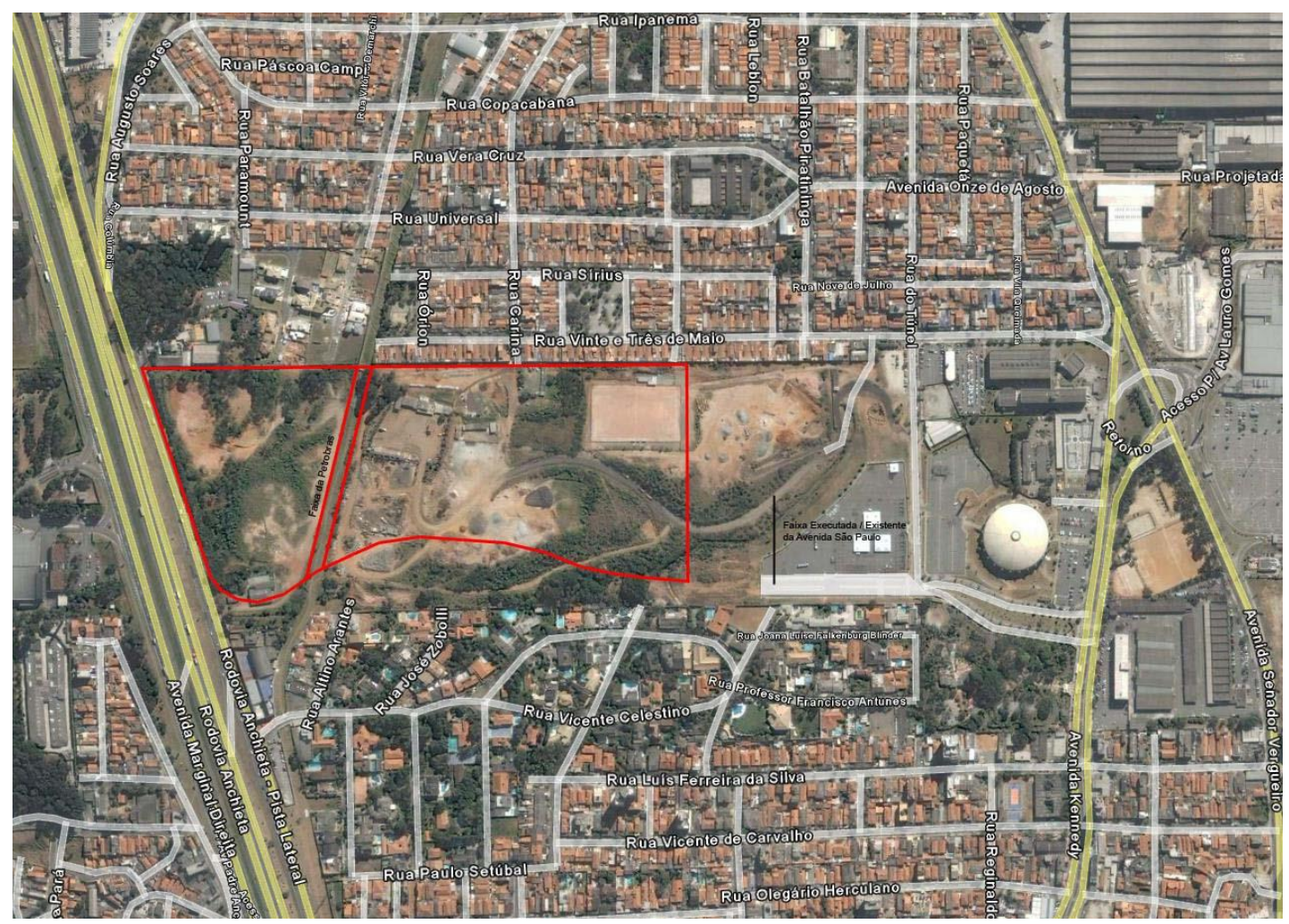

IMAGEM 69 Foto aérea do terreno do campus São Bernardo. Fonte: acervo pessoal 2009

${ }^{46}$ Cf. P.A. 17758/07 da Prefeitura Municipal de São Bernardo do Campo, p. 183-193. 
Dentre as particularidades do terreno, destaca-se a presença de uma faixa reservada a um oleoduto em operação, de propriedade da Petrobras - Transpetro. A faixa ocupa aproximadamente $3.000 \mathrm{~m}^{2}$ e, na parte oeste do terreno, há um maciço florestal remanescente de Mata Atlântica.

Ao contrário do campus Santo André, que nasceu com um projeto pedagógico fundamentado nas ciências naturais e tecnologia, o campus São Bernardo nasceu com um perfil indefinido, do ponto de vista do projeto pedagógico. Por outro lado, o campus Santo André crescia rapidamente e seus espaços já não eram suficientes para comportar todas as atividades acadêmicas e assim crescia também a disputa por novos espaços dentro da comunidade acadêmica. O Reitor manifestou-se por meio de um artigo dirigido à comunidade, no qual defendia as bases da construção da UFABC:

A Universidade Federal do $A B C$ é um sistema integrado cujo projeto contempla a existência de vários campi. É assim que a UFABC deve ser entendida. Ignorar este conceito unificador é empobrecer os conceitos básicos sobre os quais ela está sendo construída. (...). Talvez alguns pensem na Universidade como um conjunto de unidades com vidas totalmente autônomas. Não deve ser assim. A UFABC é única e todos os campi devem ser inter-relacionados participando de uma troca interdisciplinar que é hoje indispensável para o progresso da ciência. (BEVILACQUA, 2008).

Ciente de seu papel de idealizador do projeto pedagógico, Bevilacqua procurou sempre mostrar a face revigorante e original do projeto, e legitimando-o na perspectiva do futuro da ciência, continua o reitor:

Entenda-se e deve ser explicitado sem medo de críticas que estamos numa trilha absolutamente original. Esta originalidade não nasce da vontade de ser diferente, mas de ser consistente com o futuro que invade rapidamente o nosso presente, que comprime a história no tempo. Toda vez que isto acontece, em semelhança a certos fenômenos físicos, forma-se uma onda de choque. Estamos passando por onda de choque e quem ignorar isso ficará irremediavelmente para trás. A construção na interface dessa onda de choque, isto é, na época de transição por que estamos passando exige muito cuidado para que passado e futuro se descolem com o mínimo de danos. (BEVILACQUA, 2008)

Em seu perfil visionário, no mesmo artigo, ele aponta caminhos que resultaram em certo arrefecimento dos conflitos gerados na comunidade acadêmica em função da disputa por espaços, permitindo um debate mais consistente sobre o futuro do campus São Bernardo e que, de fato, veio a se concretizar:

Dentro desses pressupostos fundamentais o que pode ser dito agora é que na perspectiva da proposta inicial, além dos focos de ciência e tecnologia há ainda um foco fundamental a ser implantado. Trata-se do Instituto de Cognição. O tema 
compõe atualmente o Centro de Matemática, Computação e Cognição, mas é necessário que se crie uma nova unidade onde haja convergência de outras áreas de conhecimento. Assim em torno deste Instituto e para atender a orientação essencialmente interdisciplinar desse tema deverão se criar competências em outras áreas que poderão dar origem a um centro de Ciências Humanas e Sociais com ênfases em Filosofia, História, Economia para dar alguns exemplos. (BEVILACQUA, 2008)

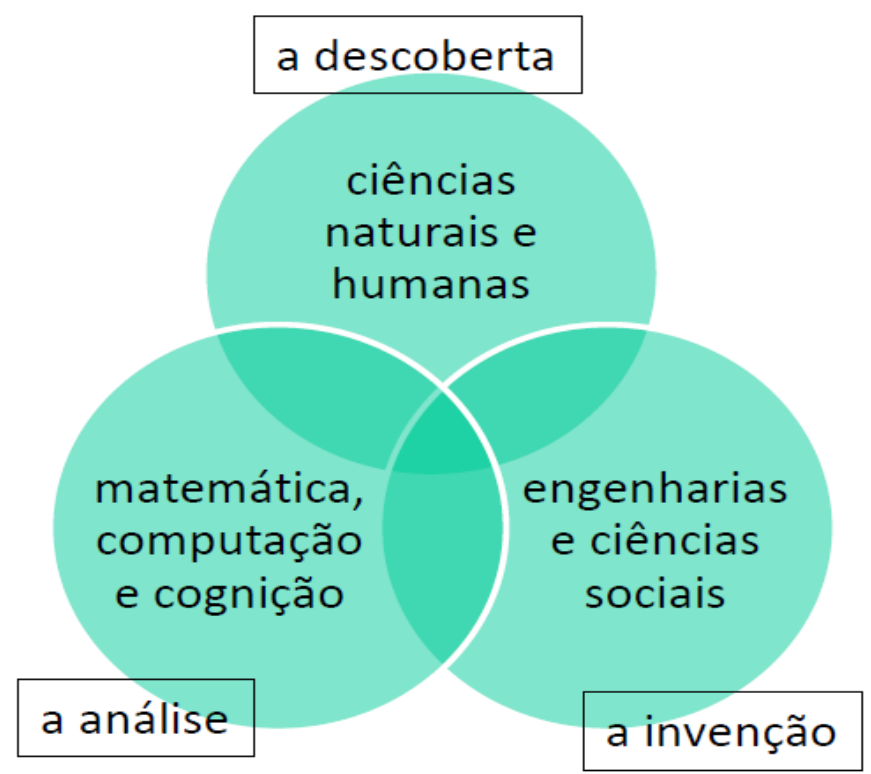

IMAGEM 70 Diagrama UFABC - Áreas do Conhecimento. Autor: Prof. Klaus Capelle
Assim, legitimou-se a matriz pedagógica da UFABC, com os centros interdisciplinares calcados no trinômio do processo do conhecimento cientifico: a descoberta, a análise e a invenção.

O artigo, publicado em março de 2008, foi norteador das competências do campus São Bernardo. Em seguida, o reitor Luiz Bevilacqua criou uma comissão de Implantação, formada por professores, presidida pelo prof. Valdecir Marvulle, diretor do Centro de

Matemática, Computação e Cognição, para elaborar um programa de necessidades. Também criou uma Coordenação Técnica, que interpretaria as demandas da comunidade acadêmica e as transformaria no programa arquitetônico para viabilizar os projetos e a construção do Campus São Bernardo. Após tomar todas as providências para legitimar a implantação do campus São Bernardo, o prof. Luiz Bevilacqua foi substituído pelo reitor Adalberto Fazzio em agosto de 2008.

O Programa Básico de Necessidades foi produto de uma ampla discussão sobre o programa pedagógico, abarcando as demandas de alunos (graduação, pós-graduação e extensão), docentes e áreas técnicas, totalizando uma área construída de 20 mil $\mathrm{m}^{2}$ em terreno de 120 mil $\mathrm{m}^{2}$, que resultou na publicação do edital para a contratação de empresa para elaboração dos estudos preliminares, projetos básicos e executivos de arquitetura, urbanismo e projetos complementares, publicado em 8 de setembro de 2008. A capacidade de 
atendimento foi definida para 3000 alunos (em dois períodos), 240 docentes e 120 funcionários ${ }^{47}$. As áreas foram assim definidas no Termo de Referência:

\begin{tabular}{|l|r|l|}
\hline \multicolumn{3}{|c|}{ RESUMO DAS ÁREAS DO PROGRAMA BÁSICO DE NECESSIDADES } \\
\hline BLOCO 1 - ENSINO & $2.800,00$ & $\mathrm{~m}^{2}$ \\
\hline BLOCO 2 - LABORATÓRIOS DIDATICOS & $2.800,00$ & $\mathrm{~m}^{2}$ \\
\hline BLOCO 3 - BIBLIOTECA/SALAS DE ESTUDOS & $1.500,00$ & $\mathrm{~m}^{2}$ \\
\hline BLOCO 4 - ANFITEATROS & $1.200,00$ & $\mathrm{~m}^{2}$ \\
\hline BLOCO 5 - REFEITÓRIO & 800,00 & $\mathrm{~m}^{2}$ \\
\hline BLOCO 6 - LABORATÓRIOS DE PESQUISA EM ENGENHARIA E DOCENTES & $4.200,00$ & $\mathrm{~m}^{2}$ \\
\hline BLOCO 7 - LABORATÓRIOS DE PESQUISA EM CIÉNCIAS DA COGNIÇÂO E & $4.200,00$ & $\mathrm{~m}^{2}$ \\
\hline SISTEMAS COMPLEXOS & $1.000,00$ & $\mathrm{~m}^{2}$ \\
\hline BLOCO 8 - COMPUTAÇÃO CIENTÍFICA E DE ALTO DESEMPENHO & $1.000,00$ & $\mathrm{~m}^{2}$ \\
\hline BLOCO 9 - ADMINISTRAÇÃO & 400,00 & $\mathrm{~m}^{2}$ \\
\hline BLOCO 10 - APOIO ESPORTIVO/ PORTARIAS & 100,00 & $\mathrm{~m}^{2}$ \\
\hline BLOCO PORTARIA PRINCIPAL & $\mathbf{2 0 . 0 0 0 , 0 0} \mathbf{~ m}^{\mathbf{2}}$ \\
\hline ÁREA TOTAL CONSTRUÍDA &
\end{tabular}

O professor Bevilacqua, ainda atuando como mentor da UFABC e empenhado em manter a universidade relevante num mundo em mutação, dedicou-se pessoalmente a implantar o Núcleo de Cognição, objetivando explorar novas possibilidades na pesquisa e na educação por meio do Bacharelado em Neurociência. A importância do Núcleo é destacada no projeto pedagógico:

O cérebro, órgão mais complexo de nosso corpo, é também crucial para entendermos os seres humanos, sendo objeto de estudo de cientistas, médicos de diversas áreas, biólogos moleculares, psicólogos experimentais e cognitivistas, anatomistas, fisiologistas e farmacologistas. A estrutura e as funções subjacentes de nosso cérebro também são objeto de interesse de engenheiros e cientistas da computação que desenvolvem interfaces humano-máquina, próteses e ambientes de realidade virtual. Da junção desses interesses científicos e aplicados pelo cérebro nasceu uma nova área, intrinsecamente multi e interdisciplinar, a qual chamamos Neurociência. Essa breve história, adicionada às novas tecnologias e demandas vindas do estudo do sistema nervoso, inspirou a criação do Bacharelado em Neurociência (BNC). (UFABC, 2006).

Engenheiro de formação, abraçou a tarefa de "projetar" os espaços dedicados ao Núcleo de Cognição no campus de São Bernardo, com a comissão de implantação e a Coordenação Técnica. Utilizando-se de bilhetes e croquis, ele foi esclarecendo as inter-relações espaciais e dando forma aos espaços que futuramente seriam os do Bloco Delta.

\footnotetext{
${ }^{47}$ Ver Anexo E - Minuta do Termo de Referência para implantação do campus São Bernardo
} 


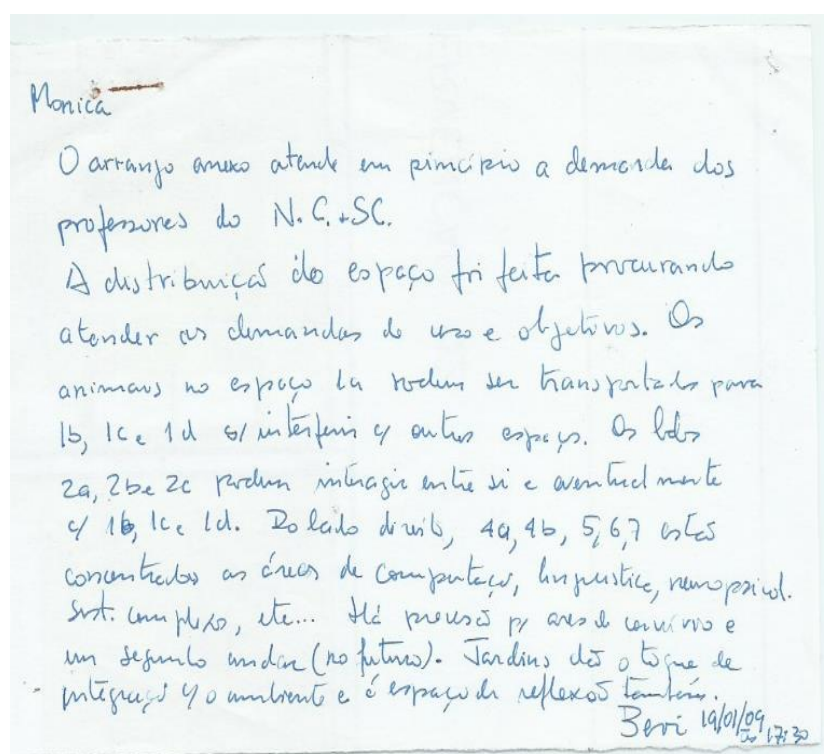

IMAGEM 71 Orientações do prof. Bevilacqua para a Coordenação Técnica. Fonte Acervo Pessoal
O arranjo anexo atende em principio a demanda dos professores do Núcleo de Cognição e Sistemas Complexos. A distribuição do espaço foi feita procurando atender as demandas de uso e objetivos. Os animais do espaço 1a podem ser transportados para $1 b$, 1c e $1 d$ sem interferir com outros espaços. Os laboratórios $2 \stackrel{a}{a}, 2 b e$ $2 c$ podem interagir entre si e eventualmente com 1b,1c e 1d. Do lado direito, 4a, 4b,5,6 e 7 estão concentradas as áreas de computação, linguística, neuropsicologia, sistemas complexos, etc. Há previsão para áreas de convívio e um segundo andar (no futuro). Jardins dão o toque de integração com o ambiente e é espaço de reflexão também.

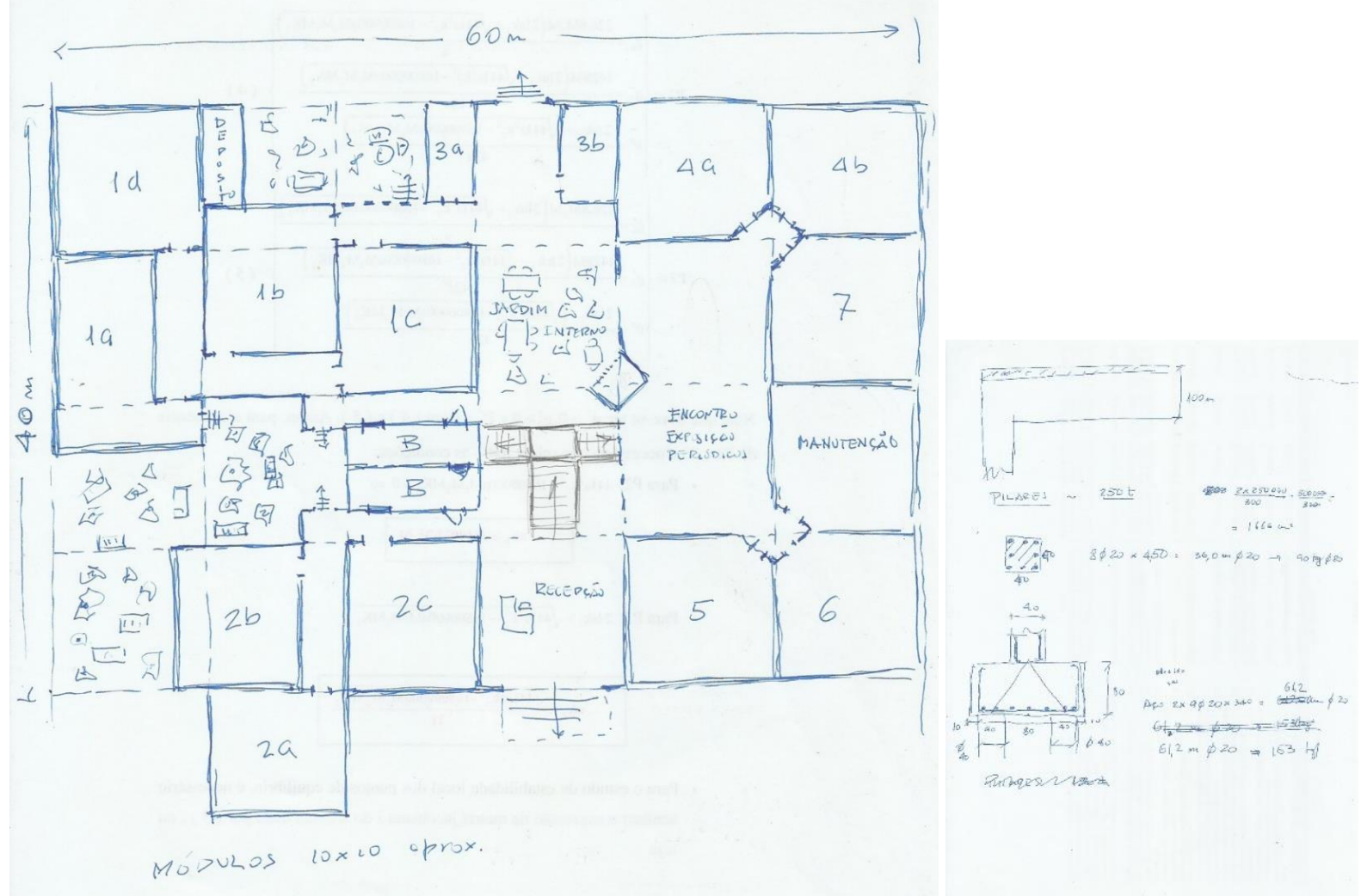

IMAGEM 72 Croquis prof. Bevilacqua para o Núcleo de Cognição 
Os croquis demonstram a dedicação e o apreço do professor Bevilacqua, não pelo edifício em si, mas pelo significado vanguardista e inovador daquela linha de pesquisa naquela área do conhecimento. Várias vezes ele confidenciou à sua equipe seu desejo de que o primeiro Prêmio Nobel brasileiro fosse concedido às pesquisas desenvolvidas na Universidade Federal do $A B C$.

A demanda do campus São Bernardo surgiu em um momento em que o campus Santo André passava por uma série de dissabores. O primeiro deles, em relação aos projetos arquitetônicos, deu-se por um equívoco cometido pelo Tribunal de Contas da União que questionou a contratação, pelo Ministério da Educação, do escritório vencedor do Concurso, LibeskindLlovet Arquitetos S/S Ltda. para o desenvolvimento dos projetos executivos. O entendimento do tribunal era de que a contratação não deveria fazer parte do prêmio. A contratação dos projetos executivos deveria dar-se por meio de nova licitação. Porém a regra do Edital do Concurso era clara e após manifestações do IAB e outras entidades nacionais de arquitetura, o Tribunal de Contas reconheceu a legalidade daquela contratação, conforme acórdão AC-2230-16/14-248, alguns anos depois. O presidente do IAB, Sérgio Magalhães, definiu a nova posição do TCU como corajosa e politicamente importante, afirmando que:

O novo acórdão tranquiliza diversos níveis de governo, que veem a matéria pacificada. Com essa decisão, o TCU retoma o caminho coerente com a cultura arquitetônica e com as suas próprias decisões de valorização da atividade de projeto completo. É uma vitória importante para os arquitetos, mas, sobretudo, um trabalho que dignifica a atuação do TCU, na medida em que refaz uma decisão que trouxe tantos transtornos" ${ }^{\prime 4}$.

Em relação à construção do campus Santo André houve também dificuldades, por tratar-se de uma obra de grande porte (aproximadamente $100.000 \mathrm{~m}^{2}$ de área construída) e complexidade. Atrasos de cronograma e divergências com a construtora, levaram a um esgarçamento da situação que, por um período, prejudicou o planejamento das atividades acadêmicas.

Tal aprendizado levou os dirigentes da UFABC a optarem por diretrizes diversas para o campus São Bernardo. Os projetos arquitetônicos foram licitados por meio da modalidade Concorrência e os edifícios seriam construídos paulatinamente, com licitações individualizadas.

\footnotetext{
48 Cf. Publicação DOU em 28 de maio de 2014

${ }^{49}$ Cf. IAB RJ. Disponível em: http://www.iabrj.org.br/novo-acordao-do-tcu-reconhece-contratacao-de-arquitetos-viaconcurso. Acesso em 13/11/16
} 
A Universidade desejava construções modulares, possibilitando uma implantação em etapas e uma maior flexibilidade espacial; sustentabilidade, com reuso de água, uso eficiente de energia, integração dos edifícios ao ecossistema local; ocupação disciplinada do terreno de forma a garantir áreas de expansão futuras. A criação de um edifício módulo, com "planta livre" que abarcasse várias atividades acadêmicas - ensino, pesquisa e extensão -, e que pudesse ser reproduzido harmonicamente no terreno, foi imperativo na concepção urbanística do projeto. Os estudos de viabilidade desenvolvidos pela coordenação técnica da UFABC contribuíram para a definição do o partido arquitetônico.

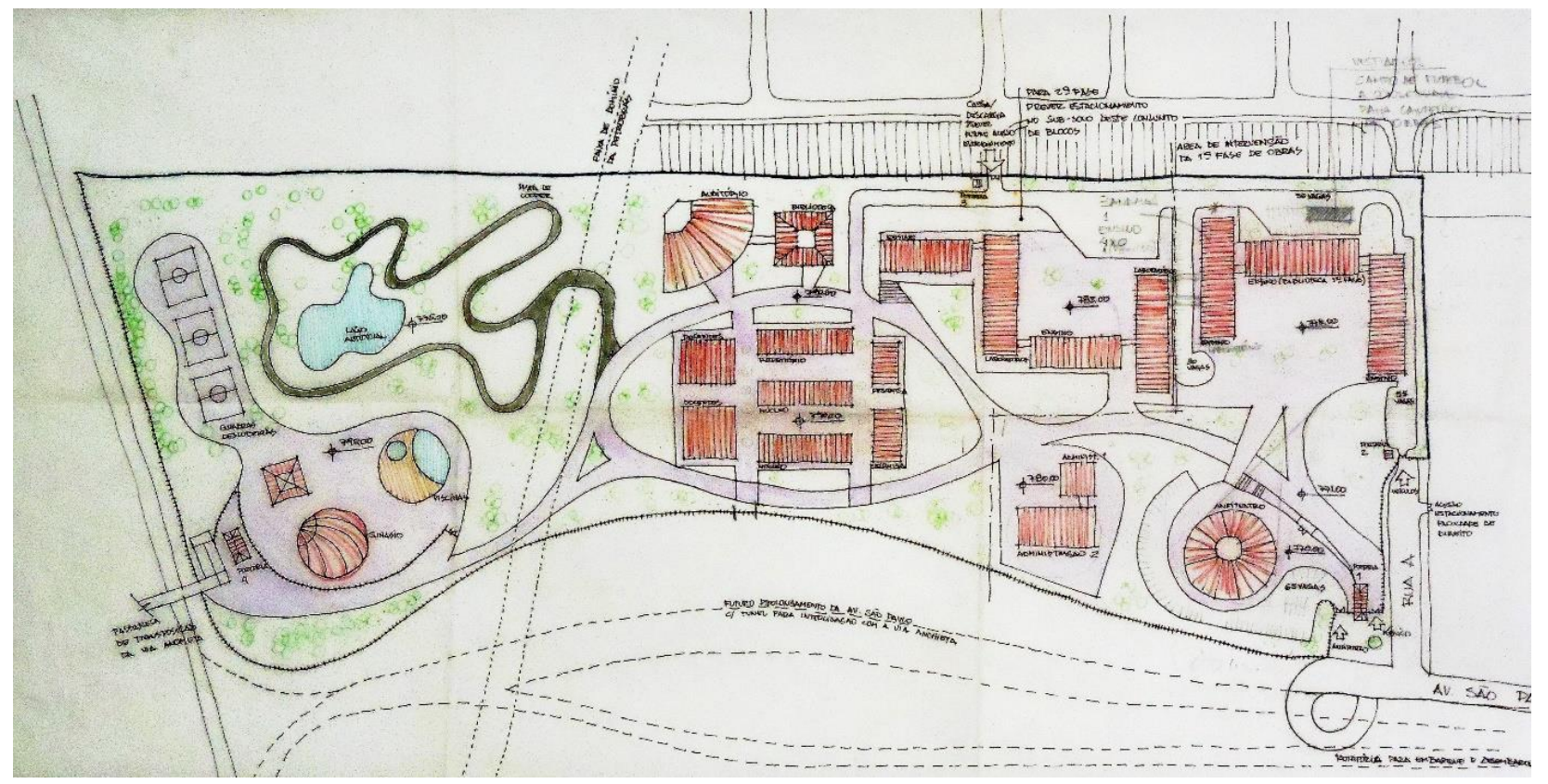

IMAGEM 73 Estudo de viabilidade desenvolvido pela coordenação técnica do campus São Bernardo. Fonte: Acervo arq. Sílvia Morales.

As empresas classificadas no processo licitatório, na modalidade Concorrência Pública, Edital 001/2008 foram Hector Vigliecca e Associados Ltda, Teúba - Arquitetura e Urbanismo EPP e Benno Perelmutter Arquitetura e Planejamento Ltda. Esta última foi declarada vencedora em dezembro de 2008, conforme DOU de 11 de dezembro de 2008.

É importante destacar que a contratação dos projetos arquitetônicos, urbanísticos e complementares envolveu uma condição de transferência de direitos patrimoniais do projeto, o que deu à UFABC, campus São Bernardo, a possibilidade de replicar o edifício módulo a qualquer tempo, de acordo com a disponibilidade de recursos para novos investimentos. 
IMAGEM 74 Benno Perelmutter (In Memoriam) e Marciel Peinado.

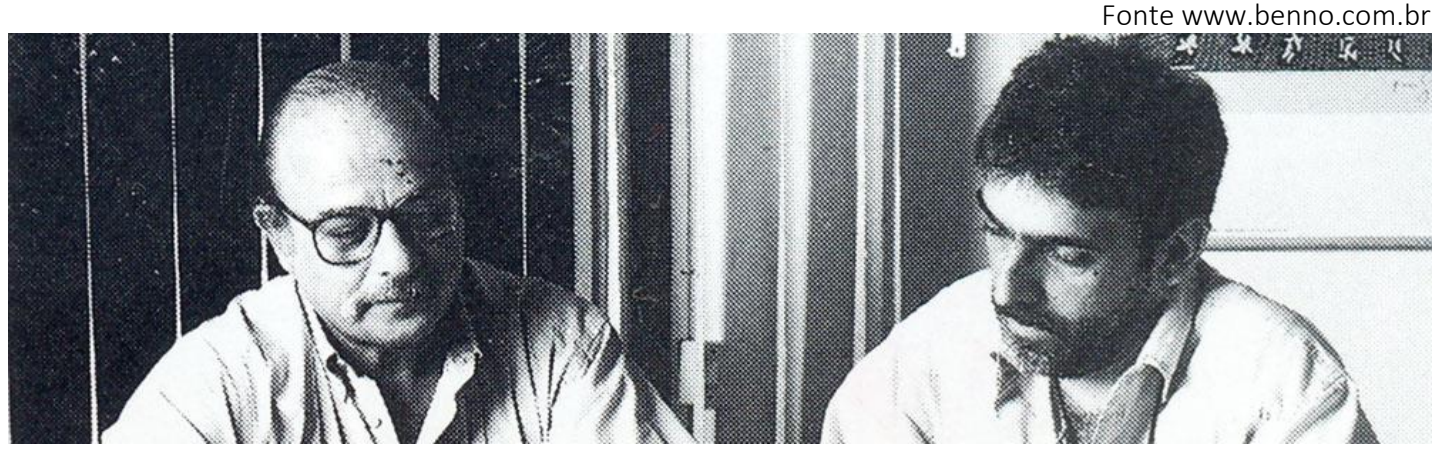


Em março de 2009, a empresa Benno Perelmutter Arquitetura e Planejamento Ltda., vencedora do certame e representada pelo arquiteto Marciel Peinado, submeteu à aprovação da universidade 3 propostas de estudos urbanísticos para o campus, em reunião realizada com a sua coordenação técnica e com a presença do Reitor pro tempore Adalberto Fazzio, do ViceReitor Armando Milioni, do Pró-Reitor de Planejamento e Desenvolvimento Institucional Ricardo Siloto e de seu adjunto, Ricardo Moretti. Foi registrada em Ata a aprovação da proposta 2, de forma que a empresa pode dar continuidade aos projetos básicos, legais e executivos, conforme previsto em contrato.

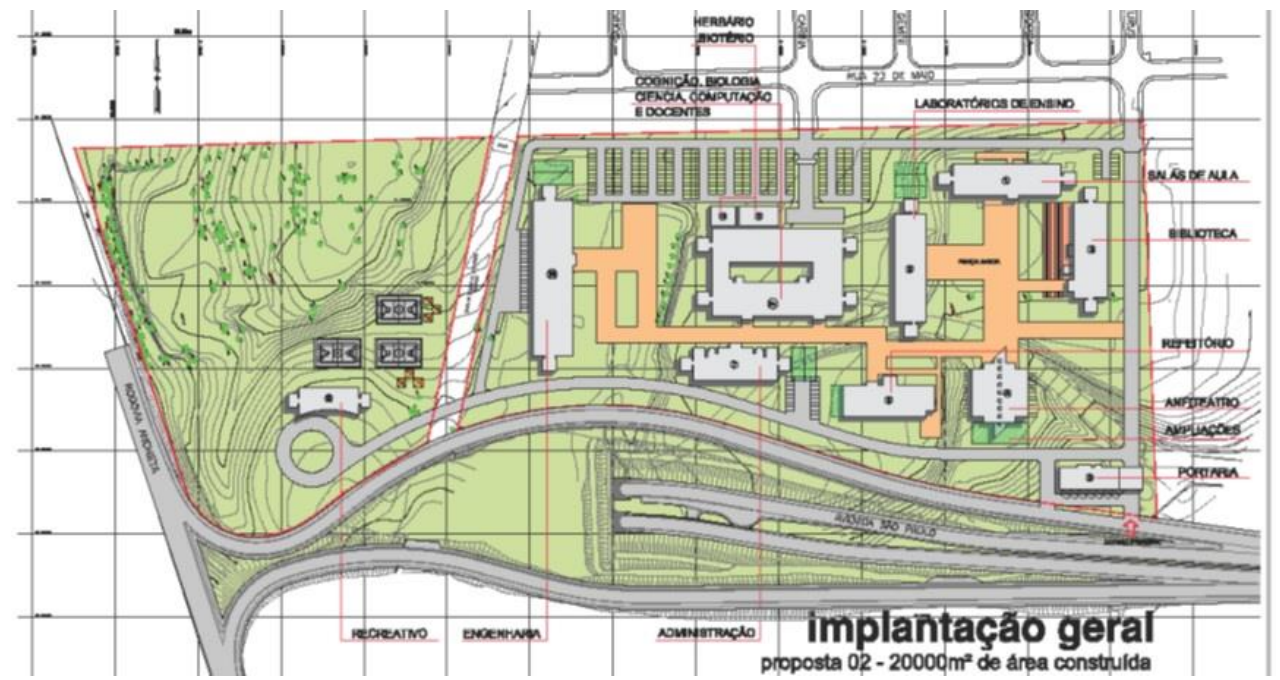

IMAGEM 75 Proposta n. 2 do estudo de implantação aprovada pela equipe dirigente. Fonte UFABC, ProPladi

A proposta 3, porém, feita pelos arquitetos, tinha seu mérito e cabe apresentá-la aqui porque guarda, preliminarmente, características que remetem às megaestruturas das universidades europeias dos anos 1960 apresentadas no capítulo 1.

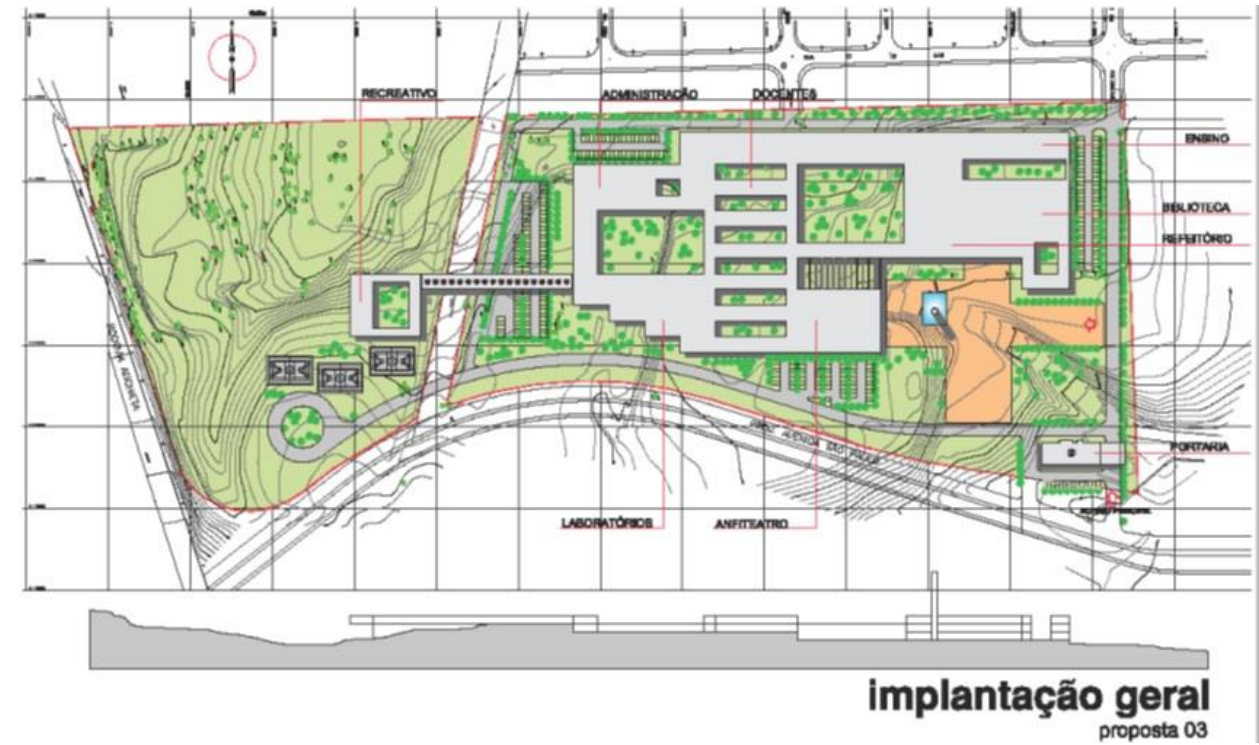

IMAGEM 76 Proposta 3 Implantação Campus São Bernardo. Fonte UFABC, Propladi 
O projeto urbanístico definitivo resultou em uma implantação com vários edifícios modulares circundados por um sistema viário para automóveis e ciclovias, preservando as vias de pedestres entre os edifícios; criando uma grande praça que permite acesso aos principais edifícios: graduação, pesquisa, biblioteca, auditórios e refeitório.

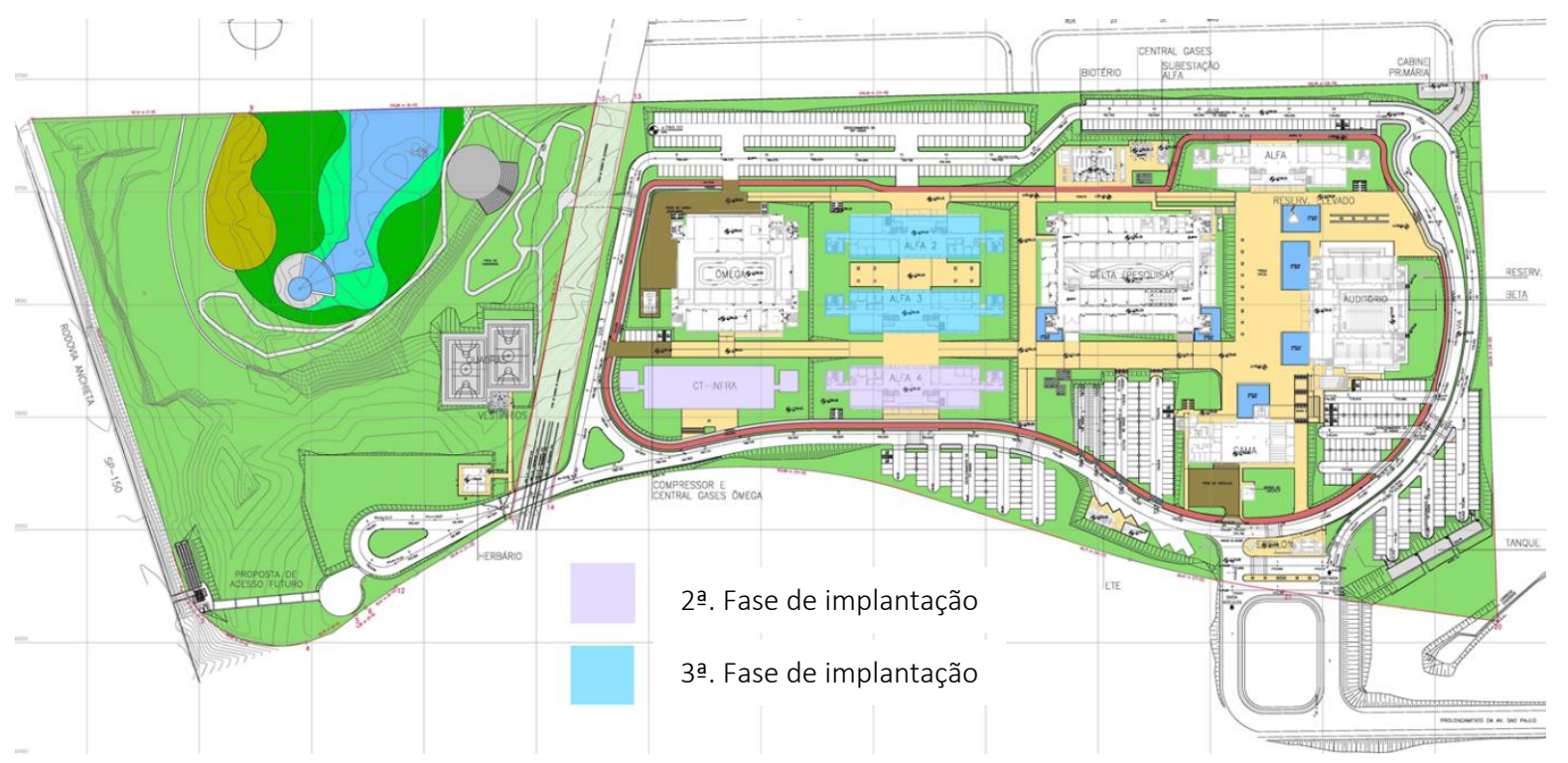

IMAGEM 77 Projeto definitivo de implantação do campus São Bernardo.

Fonte Benno Perelmutter, 2010.

O desenvolvimento dos projetos executivos levou 15 meses. No entanto, nos 10 primeiros meses, foram desenvolvidos os projetos do edifício modular, o que permitiu licitar a obra - o Bloco Alfa - e a infraestrutura do terreno, definidos como 1a . fase de implantação. A 2a. fase e a 3a . fase de implantação foram planejadas para um horizonte de 5 a 10 anos, resultando em $45.000 \mathrm{~m}^{2}$ de área construída, conforme gráfico:

\begin{tabular}{|c|c|c|c|c|}
\hline \multirow[t]{2}{*}{ 1a. Fase - } & & \multicolumn{2}{|c|}{$26.368,88 \mathrm{~m}^{2}$} & \multirow[b]{2}{*}{ Graduação } \\
\hline & Bloco Alfa & $4.626,00$ & $\mathrm{~m}^{2}$ & \\
\hline & Bloco Beta & $4.170,00$ & $\mathrm{~m}^{2}$ & Biblioteca 40 mil livros \\
\hline & & & & Auditorio 400 lugares \\
\hline & & & & 4 Salas Anfiteatro \\
\hline & Bloco Gama & $1.426,00$ & $\mathrm{~m}^{2}$ & Refeitorio \\
\hline & & & & Manutenção \\
\hline & Bloco Delta & $12.323,00$ & $\mathrm{~m}^{2}$ & Laboratorios Pesquisa NCSC \\
\hline & & & & 200 salas professores \\
\hline & Bloco Omega & $2.920,00$ & $\mathrm{~m}^{2}$ & Laboratorios Pesquisa Engenharias \\
\hline & Biotério & 543,88 & $\mathrm{~m}^{2}$ & \\
\hline & Herbário & 120,00 & $\mathrm{~m}^{2}$ & \\
\hline & Caixa d’Agua & 240,00 & $\mathrm{~m}^{2}$ & \\
\hline \multirow[t]{3}{*}{ 2a. Fase - } & & $9.252,00$ & $\mathrm{~m}^{2}$ & \\
\hline & Bloco CTInfra & $4.626,00$ & $\mathrm{~m}^{2}$ & Pesquisa \\
\hline & Alfa 2 & $4.626,00$ & $\mathrm{~m}^{2}$ & Graduação \\
\hline 3a. Fase - & & $9.252,00$ & $\mathrm{~m}^{2}$ & \\
\hline & Alfa 3 & $4.626,00$ & $\mathrm{~m}^{2}$ & Ampliação \\
\hline & Alfa 4 & $4.626,00$ & $\mathrm{~m}^{2}$ & Ampliação \\
\hline
\end{tabular}




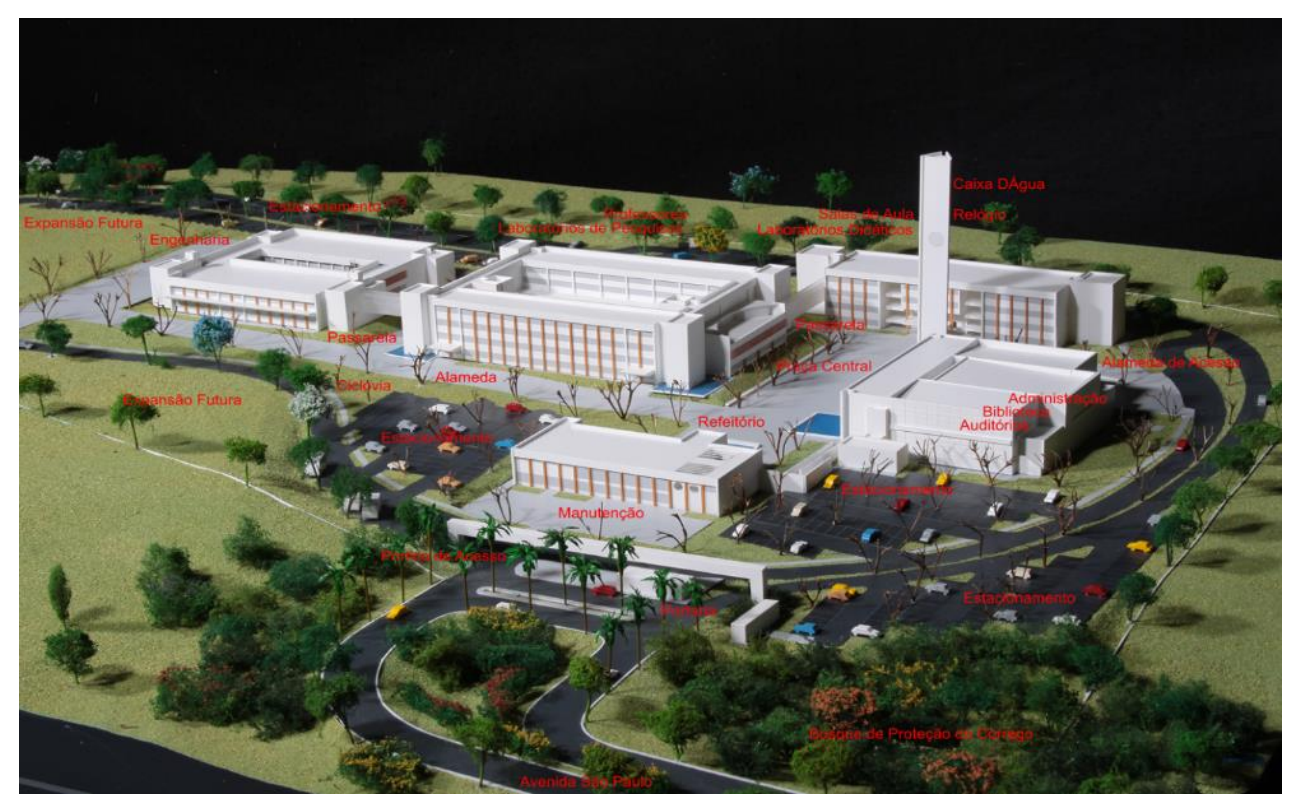

IMAGEM 78 Foto da maquete campus São Bernardo vista norte. Fonte Benno Perelmutter, 2010.

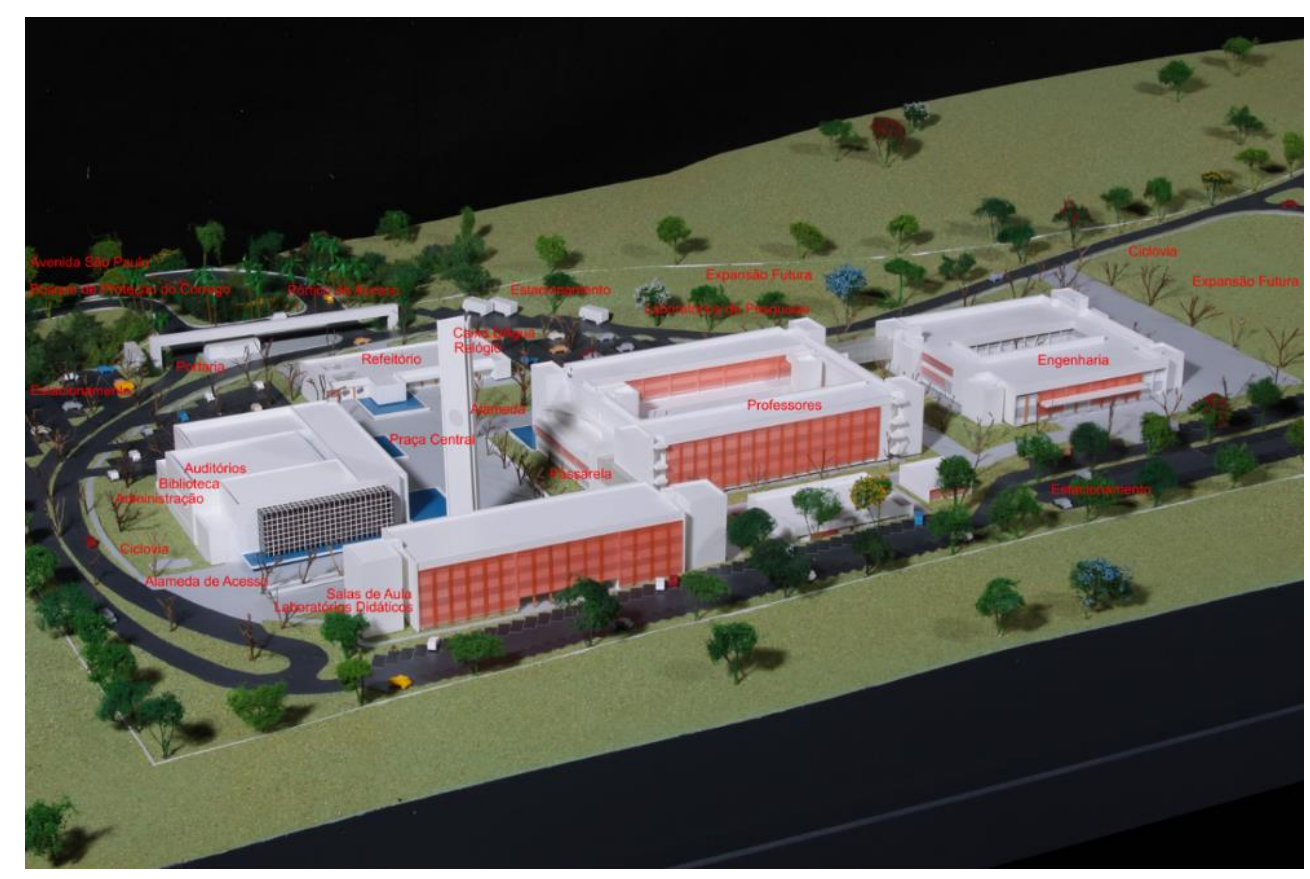

IMAGEM 79 Foto maquete campus São Bernardo vista sul. Fonte Benno Perelmutter, 2010.

\section{BLOCO ALFA - área $4.626 \mathrm{~m}^{2}$}

É o edifício módulo, em lâmina com 4 pavimentos, com circulação central e com shafts e sanitários nas extremidades. O edifício Alfa 1, da graduação, foi assim configurado:

Pavimento Térreo - Espaço de convivência, secretaria e laboratórios de informática;

Primeiro Pavimento - Salas de aula, sala de estudo e laboratórios de informática;

Segundo Pavimento - Salas de aula e sala de estudo;

Terceiro Pavimento - Salas de estudo, laboratórios úmidos e secos. 


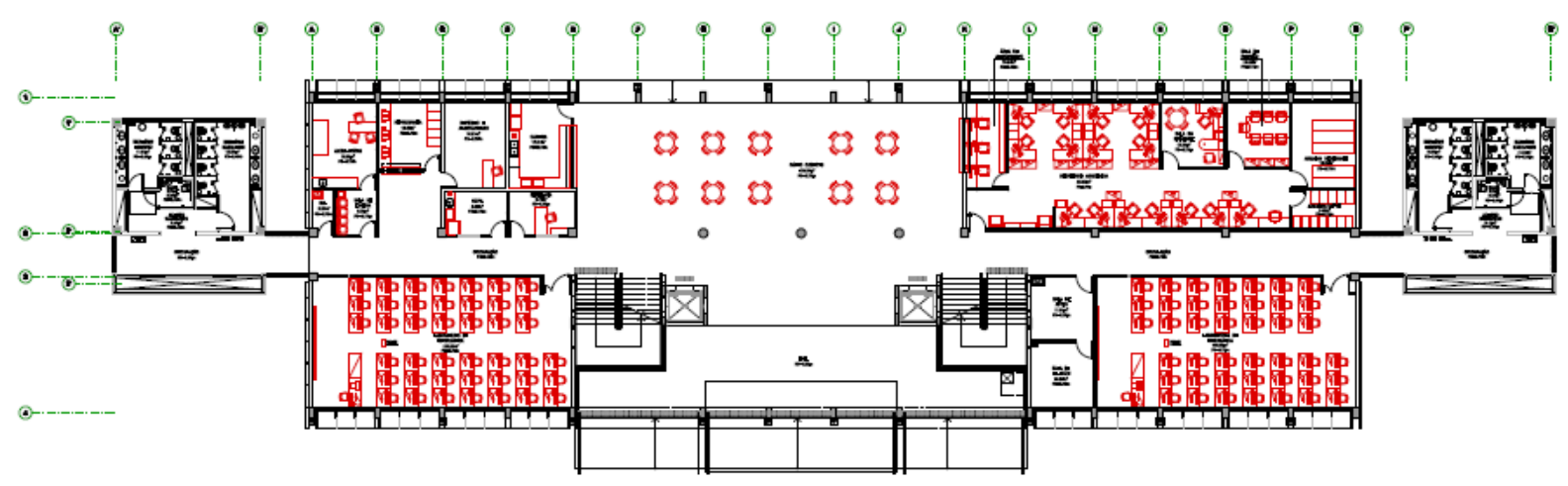

IMAGEM 80 Bloco Alfa Térreo.

Fonte Benno Perelmutter Arquitetura e Planejamento

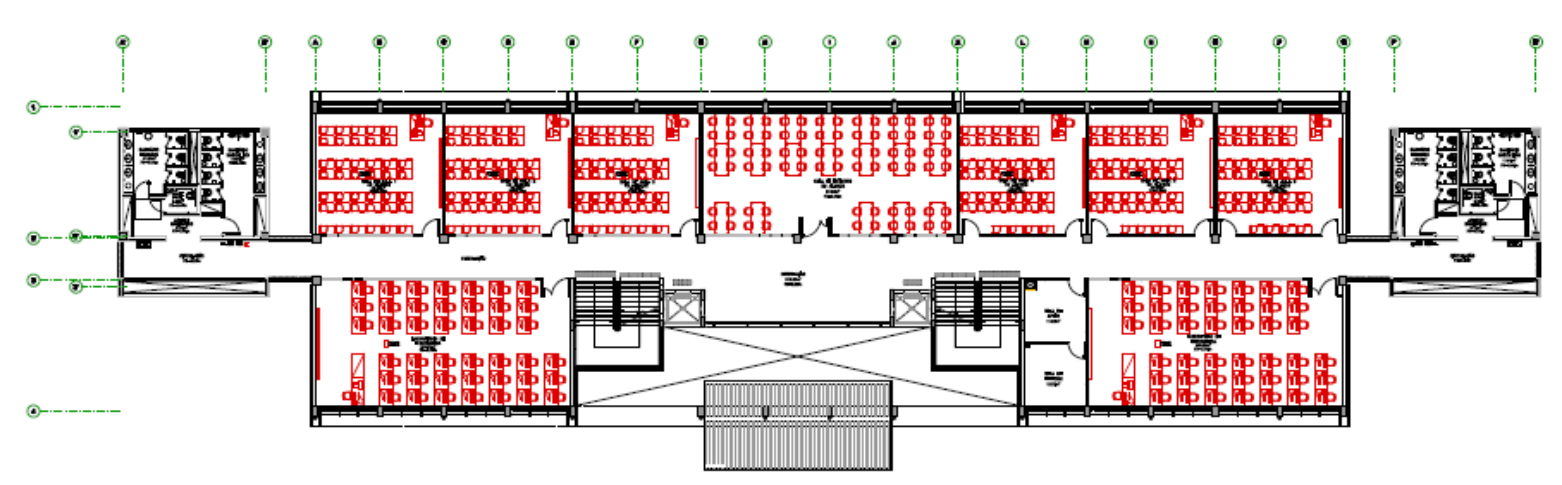

IMAGEM 81 Primeiro Pavimento

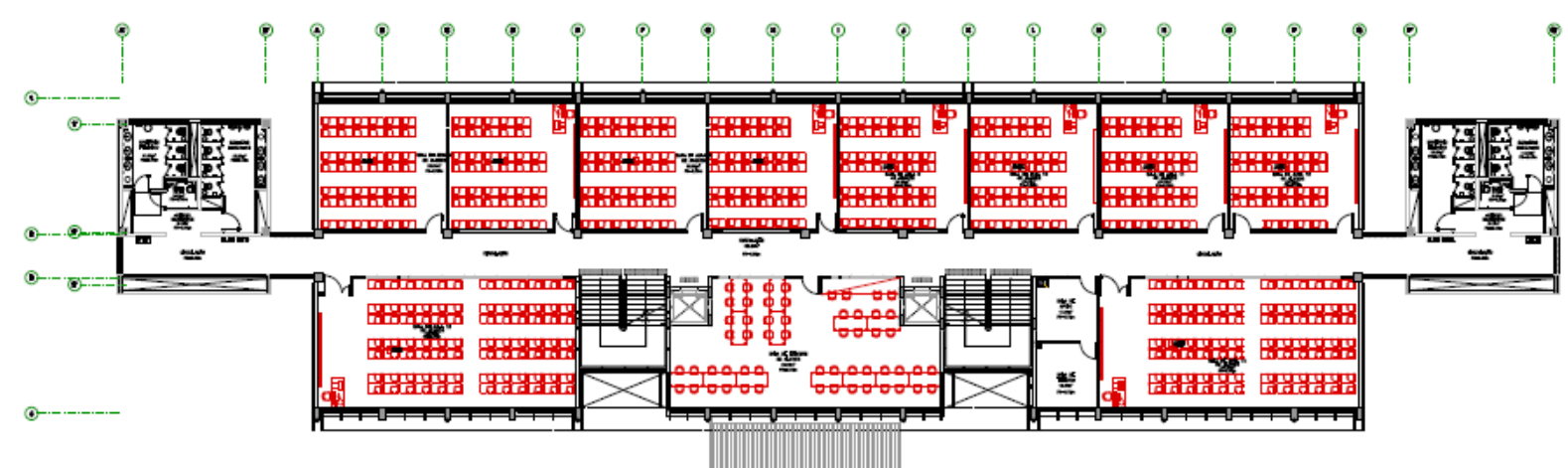

IMAGEM 82 Segundo Pavimento

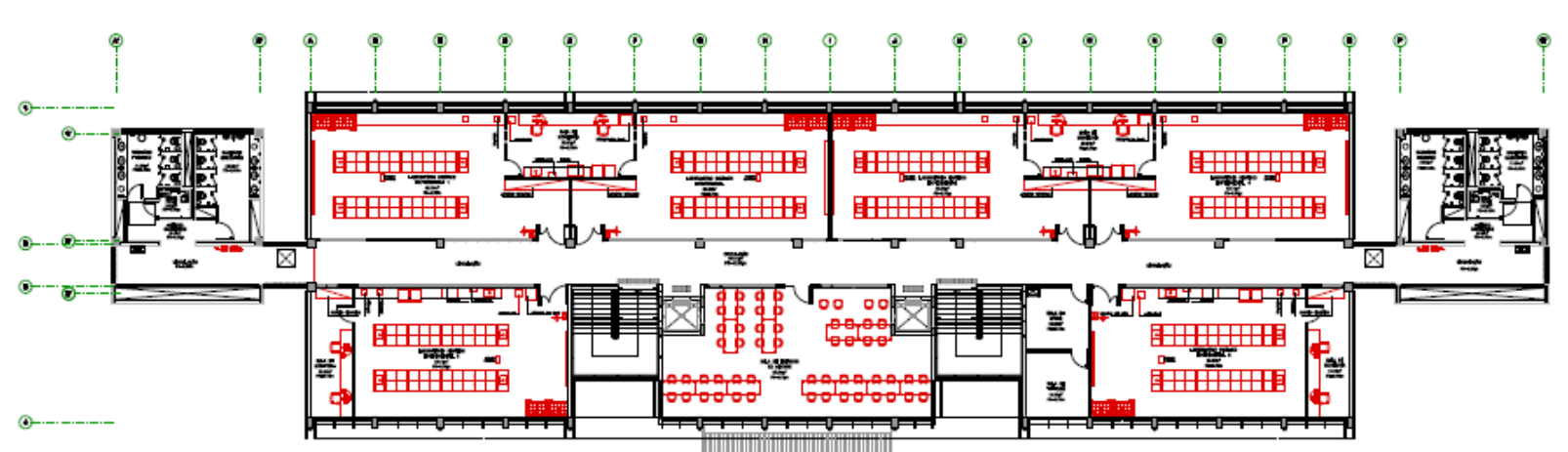

IMAGEM 83 Terceiro Pavimento 
BLOCO BETA - área $4.170 \mathrm{~m}^{2}$

Compõe-se de um auditório de 400 lugares, 4 anfiteatros para aulas e biblioteca.
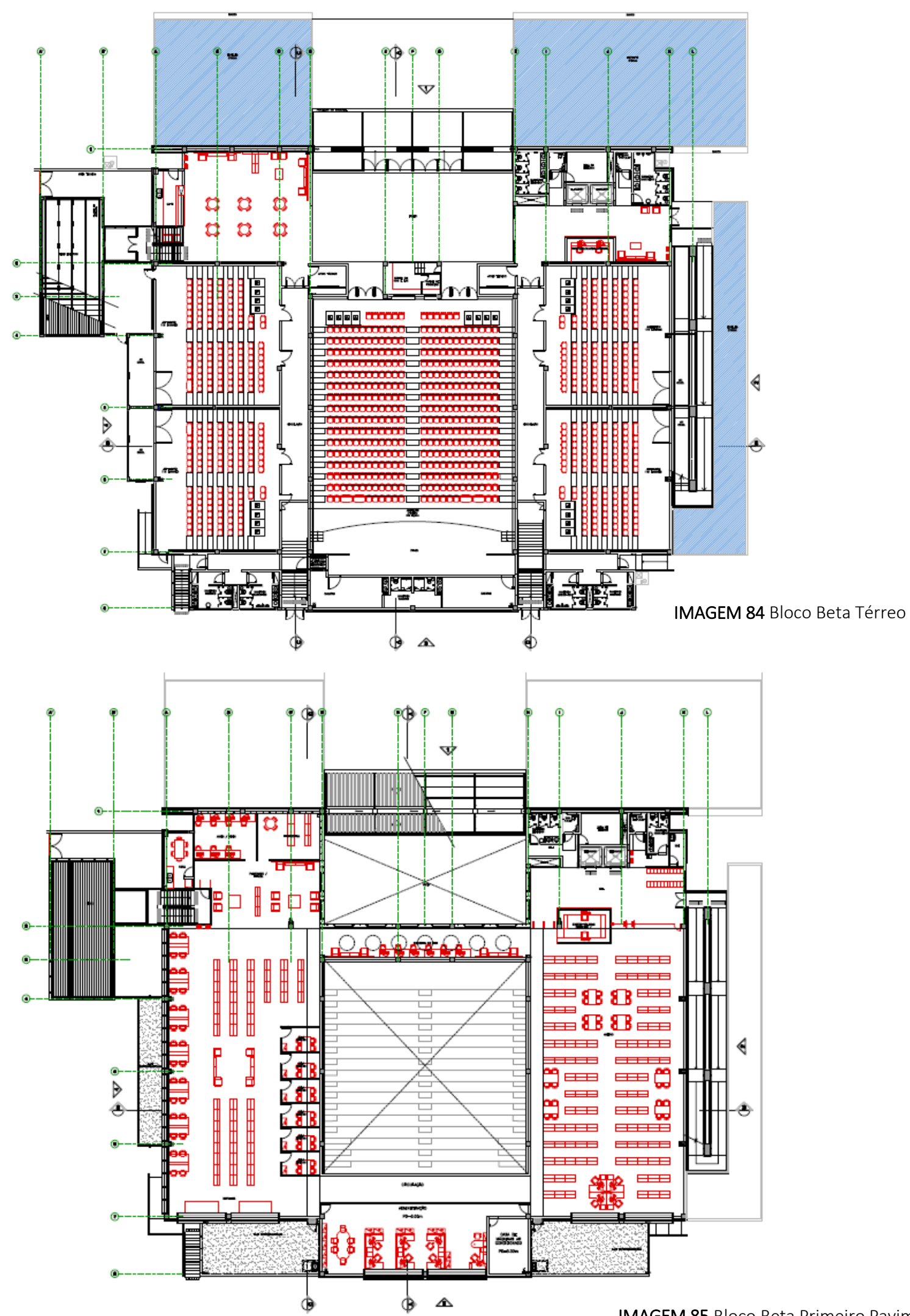

IMAGEM 85 Bloco Beta Primeiro Pavimento 


\section{BLOCO GAMA - área $1.426 \mathrm{~m}^{2}$}

É o edifício do refeitório para 400 estudantes. No pavimento inferior, situa-se a equipe da manutenção do campus.
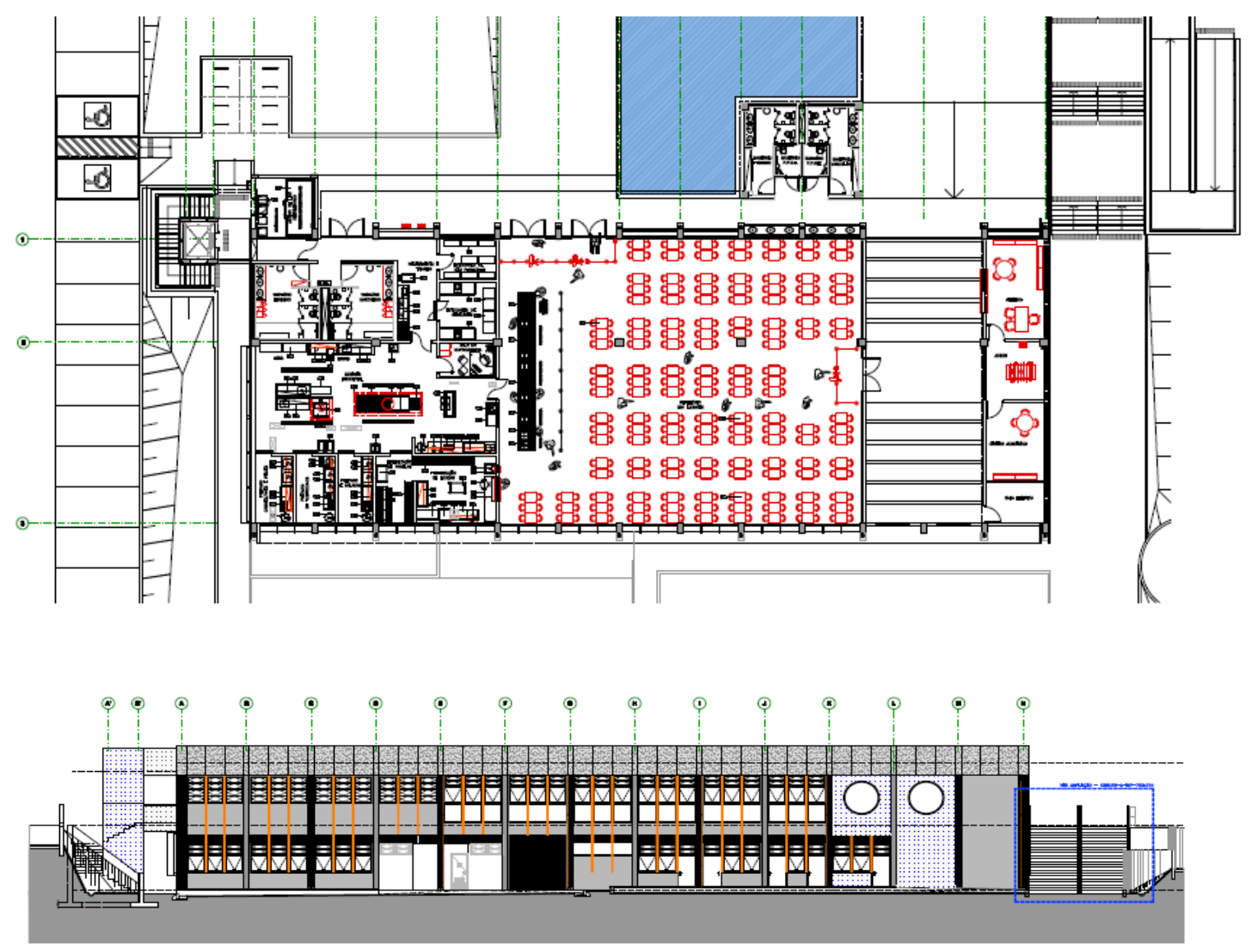

IMAGEM 86633 Bloco Gama refeitório planta e elevação

\section{BLOCO DELTA - área $12.323 \mathrm{~m}^{2}$}

O Bloco Delta é o edifício da pesquisa e das salas dos docentes.

Pavimento Térreo - Data Center e Núcleo de Ciências, Tecnologia e Sociedade, hoje pertencente ao Bacharelado em Ciências e Humanidades.

Primeiro Pavimento - Núcleo de Pesquisa da Neurociência e Cognição.

Segundo e Terceiro Pavimentos - Salas de estudo duplas para 240 docentes contratados em regime de dedicação exclusiva. 


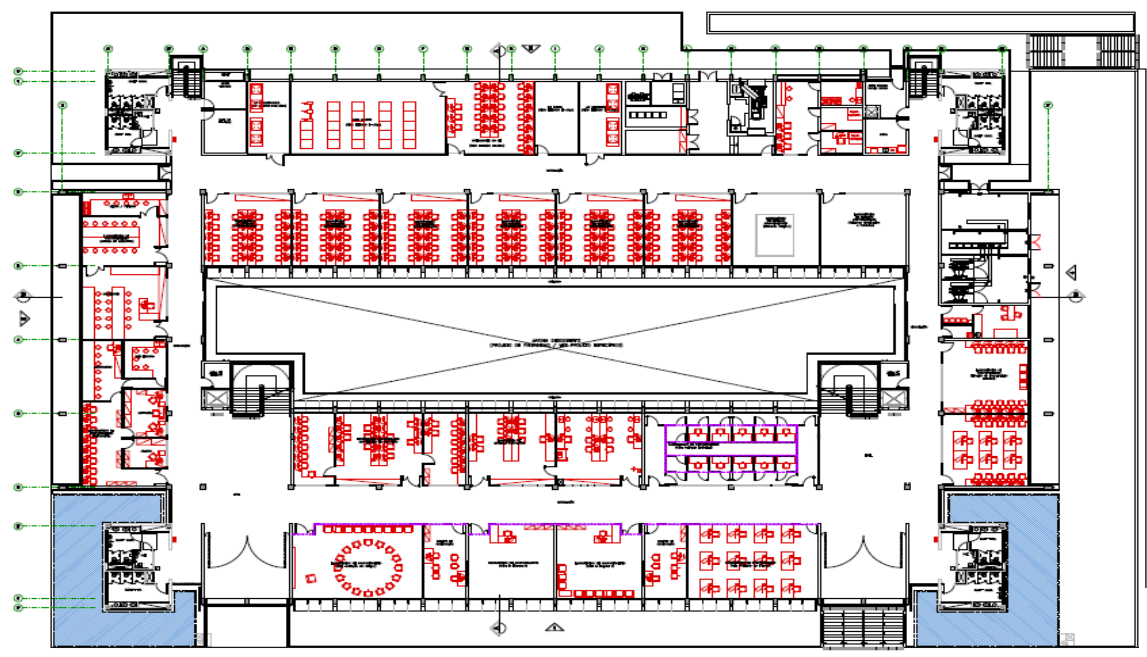

IMAGEM 87 Bloco Delta Térreo

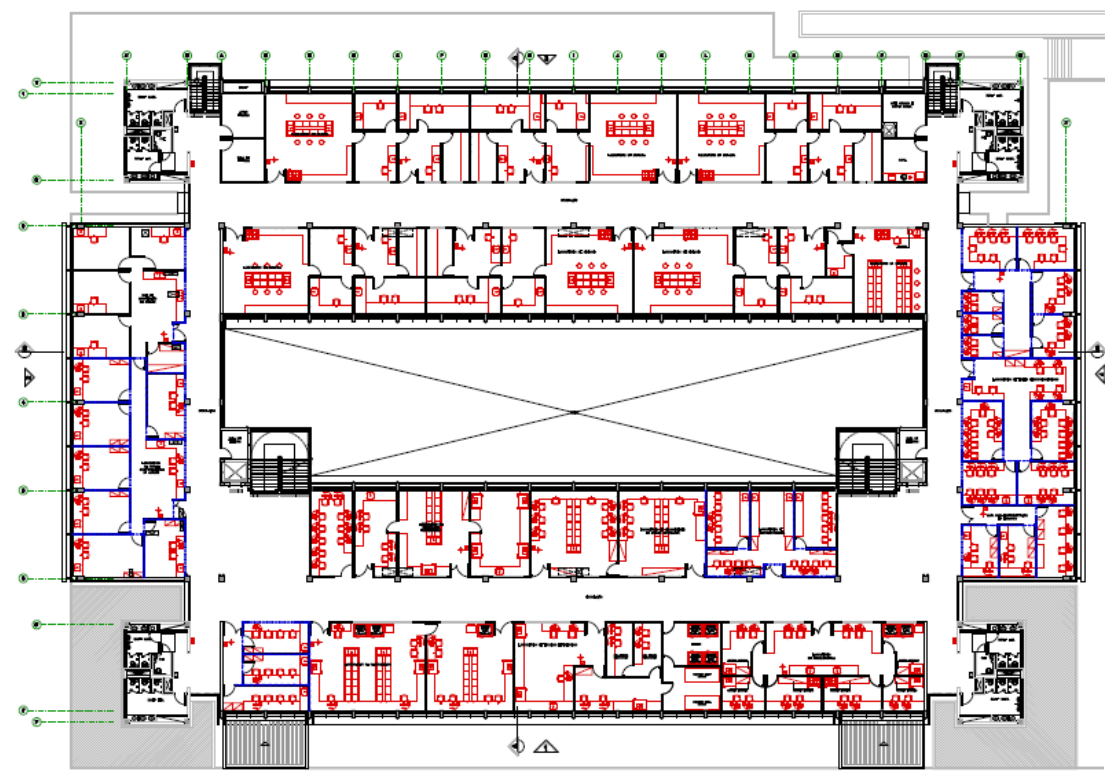

IMAGEM 88 Bloco Delta 1ํ. Pavimento

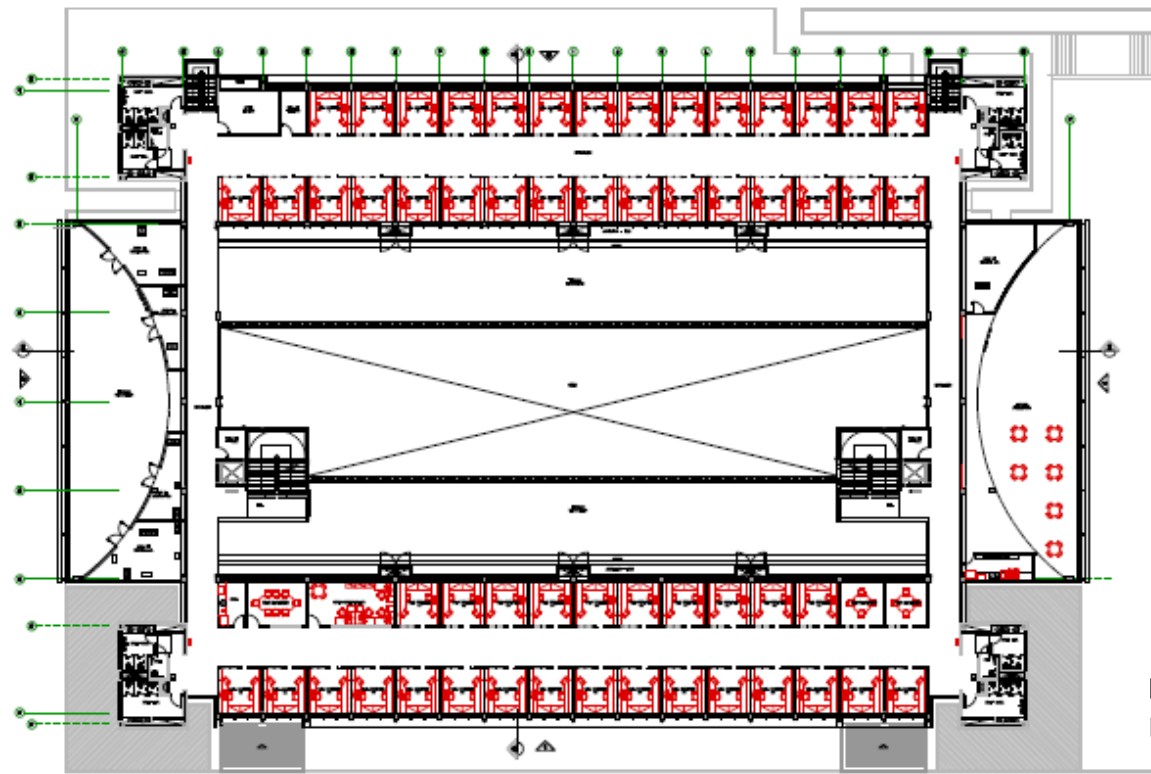

IMAGEM 89

Bloco Delta 20. e 3o. Pavimentos 


\section{BLOCO ÔMEGA - área $2.920 \mathrm{~m}^{2}$}

É o edifício dos laboratórios de pesquisa das engenharias aeroespacial, ambiental, de energia, de gestão, robótica e de materiais.

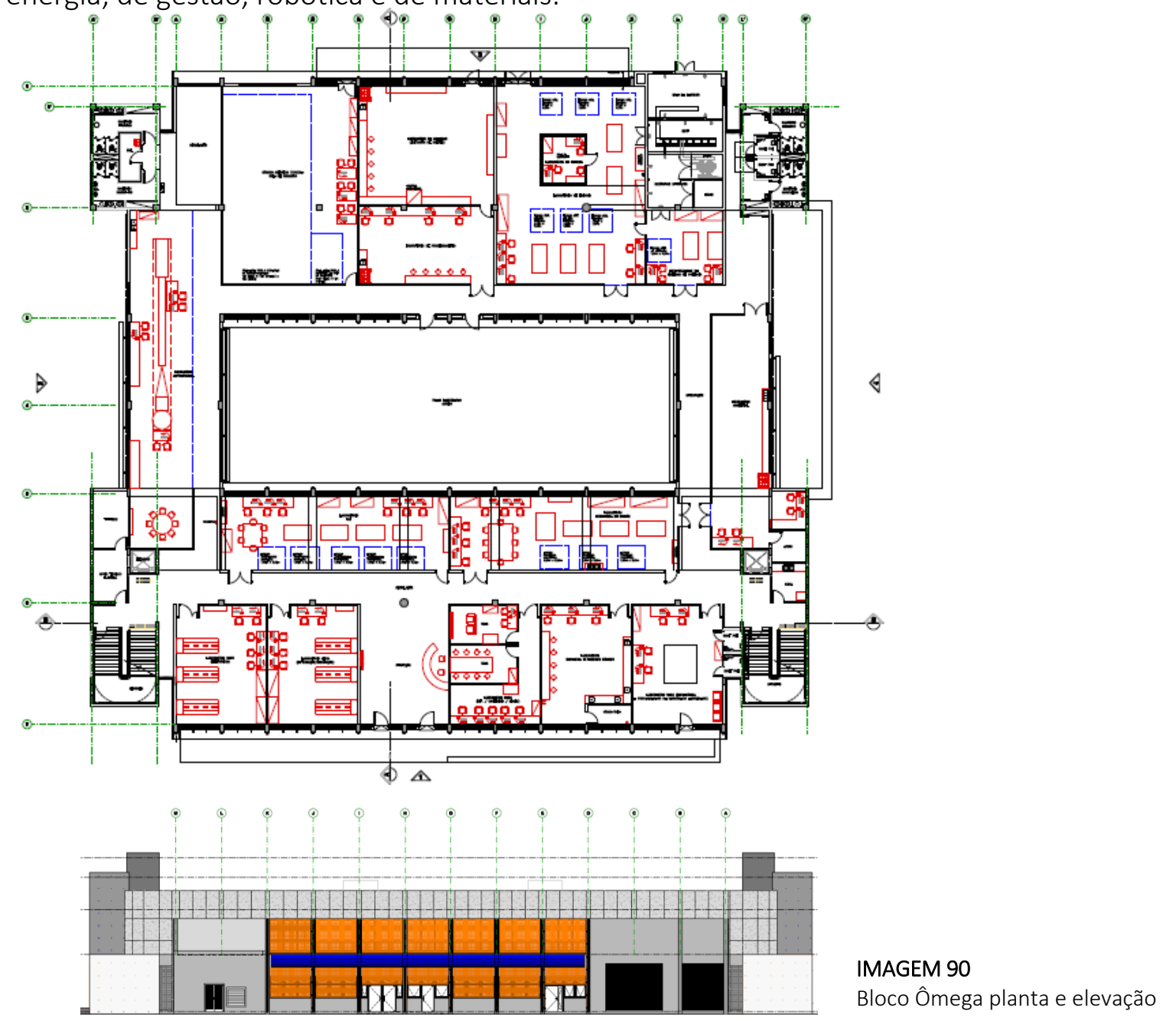

Cabe ainda destacar o projeto do biotério de experimentação, localizado ao lado do Bloco Delta, para experimentos do núcleo de neurociências, onde se procura padronizar o ambiente, a alimentação e o manejo de ratos e camundongos, de acordo com normas específicas. É fundamental para o desenvolvimento de pesquisas de cognição. Há também um herbário para pesquisas das ciências biológicas.

Foi previsto um sistema de captação de águas pluviais dos telhados para todos os edifícios aqui apresentados. A água proveniente dessa captação é utilizada em bacias sanitárias e a manutenção de áreas verdes. Segundo o Plano de Gestão de Logística Sustentável ${ }^{50}$ da UFABC, o projeto encontra-se em implantação.

50 Cf. UFABC. Plano de Logística Sustentável. Disponível em: http://propladi.ufabc.edu.br/desenvolinstitucional/pls Acesso em 13/01/2017. 

segundo Rodriguez:

Edificações em malha modular (a UFMG foi a precursora e serviu de base para a FUAM, para o Campus do Vale da UFRGS, entre outros): passou-se a perseguir uma unidade arquitetônica que, com base no módulo espacial, viabilizasse o módulo acadêmico - o Departamento. O tema foi tratado de forma tão contundente que há campi que são inteiramente edificados em blocos-tipo, como o da UNIFOR, o da UEFS, ou o projeto para a UCSal. Na verdade, a composição tipificada é um ideal perseguido durante esses últimos 30 anos e se não há uma variedade maior de exemplos é porque outras universidades não dispuseram dos recursos financeiros necessários para construir seus campi de uma só vez, e, com isso, a cada espaço de tempo os planos diretores alteravam-se, e novas tipologias iam sendo propostas, gerando diferentes formas-tipo no interior de um mesmo campus. (2001, p. 46)

A adoção, no entanto, de um edifício módulo para orientar o crescimento e expansão do campus São Bernardo revelou-se uma decisão apropriada para a sustentação de uma unidade urbanística, dada as condições orçamentárias naquele momento.

\begin{tabular}{|c|c|c|c|c|c|c|}
\hline \multicolumn{3}{|c|}{ Empresas Vencedoras dos Certames } & \multirow[t]{2}{*}{ Área $\left(\mathrm{m}^{2}\right)$} & \multirow{2}{*}{\begin{tabular}{|c|}
$\begin{array}{c}\text { Valor do } \\
\text { Contrato }\end{array}$ \\
$\mathrm{R} \$ 1.180 .369,80$ \\
\end{tabular}} & \multirow{2}{*}{$\begin{array}{c}\begin{array}{c}\text { Vigencia do } \\
\text { Contrato }\end{array} \\
26 / 12 / 2008 \text { a } \\
25 / 10 / 2009\end{array}$} & \multirow{2}{*}{\begin{tabular}{|c} 
Fonte \\
DOU \\
$26 / 12 / 2008$
\end{tabular}} \\
\hline 1. & $\begin{array}{l}\text { Projetos Completos de Arquitetura, } \\
\text { Urbanismo e Complementares }\end{array}$ & \begin{tabular}{|c|} 
Benno Perelmutter \\
Arquitetura e \\
Planejamento Ltda
\end{tabular} & & & & \\
\hline 2. & Gerenciamento de Projetos e Obras & $\begin{array}{c}\text { Geribello } \\
\text { Engenharia Ltda }\end{array}$ & & $\mathrm{R} \$ 2.520 .000,00$ & $\begin{array}{c}03 / 03 / 2009 \text { a } \\
02 / 03 / 2011 \\
\end{array}$ & \begin{tabular}{|c|} 
DOU \\
$03 / 03 / 2009$ \\
\end{tabular} \\
\hline 3. & Terraplanagem & $\begin{array}{c}\text { Schunck } \\
\text { Terraplenagem e } \\
\text { Transportes } \\
\end{array}$ & $120.000,00$ & $\mathrm{R} \$ 4.845 .067,38$ & $\begin{array}{l}\text { 30/12/2009 Á } \\
30 / 12 / 2010\end{array}$ & $\begin{array}{c}\text { DOU } \\
30 / 12 / 2009\end{array}$ \\
\hline 4. & $\begin{array}{l}\text { Construção Edificio Salas de Aula, Sistema } \\
\text { Viario e Infraestrutura }\end{array}$ & $\begin{array}{l}\text { JWA Engenharia } \\
\text { Ltda }\end{array}$ & $4.626,00$ & $R \$ 18.602 .576,56$ & $\begin{array}{c}\text { 30/12/2009 Á } \\
30 / 12 / 2011\end{array}$ & $\begin{array}{c}\text { DOU } \\
30 / 12 / 2009 \\
\end{array}$ \\
\hline 5. & $\begin{array}{l}\text { Construção da Biblioteca, Refeitorio, } \\
\text { Edificio de Pesquisa, Biotério, Herbário e } \\
\text { Urbanismo }\end{array}$ & $\begin{array}{l}\text { Hudson Engenharia } \\
\text { Ltda }\end{array}$ & $21.742,88$ & $\mathrm{R} \$ 42.832 .311,19$ & $\begin{array}{l}27 / 09 / 2010 \text { a } \\
27 / 09 / 2012\end{array}$ & $\begin{array}{c}\text { DOU } \\
27 / 09 / 2010\end{array}$ \\
\hline 6. & Construção Bloco Alfa 2 e Bloco Zeta & $\begin{array}{c}\text { Hudson Engenharia } \\
\text { Ltda }\end{array}$ & $9.252,00$ & $\mathrm{R} \$ 25.461 .944,97$ & $\begin{array}{c}19 / 12 / 2011 \text { a } \\
18 / 12 / 2013 \\
\end{array}$ & \begin{tabular}{|l|} 
DOU \\
$19 / 12 / 2011$ \\
\end{tabular} \\
\hline \multicolumn{3}{|c|}{ Total de Recursos para Implantação do Campus São Bernardo } & $35.620,88$ & $\mathrm{R} \$ \mathbf{9 5 . 4 4 2 . 2 6 9 , 9 0}$ & & \\
\hline
\end{tabular}

A experiência de implantação do campus São Bernardo foi bem-sucedida em função de seu planejamento. O período dedicado ao desenvolvimento dos projetos (15 meses) produziu um montante de informações (projetos, planilhas, detalhamentos, etc.) que permitiu licitar suas obras com projetos executivos, graças ao comprometimento da empresa projetista. Somase a isso a contratação de uma empresa de engenharia consultiva. No momento inicial da implantação do campus, a universidade não contava com um quadro de técnicosadministrativos disponíveis para o campus São Bernardo, implicando a contratação da gerenciadora com experientes engenheiros e arquitetos que apoiaram a UFABC na fiscalização 
dos projetos e das obras. A coordenação do campus São Bernardo convidou os órgãos de controle - Tribunal de Contas da União (TCU) - a acompanhar a construção do campus desde o início e a equipe de fiscais do TCU orientou-os sobre como fazer e organizar as prestações de contas dos recursos públicos de forma objetiva, ética e transparente. Essa ação conjunta colaborou eficientemente para a concretização do empreendimento.

Atualmente, o campus São Bernardo está na 2a . fase de implantação e, como todo projeto, passa por um ajuste de perspectivas, de orçamentos, de possibilidades materiais e alguns acidentes de percurso, porém sua visibilidade acadêmica cresce em consonância com o aumento de número de alunos atendidos.

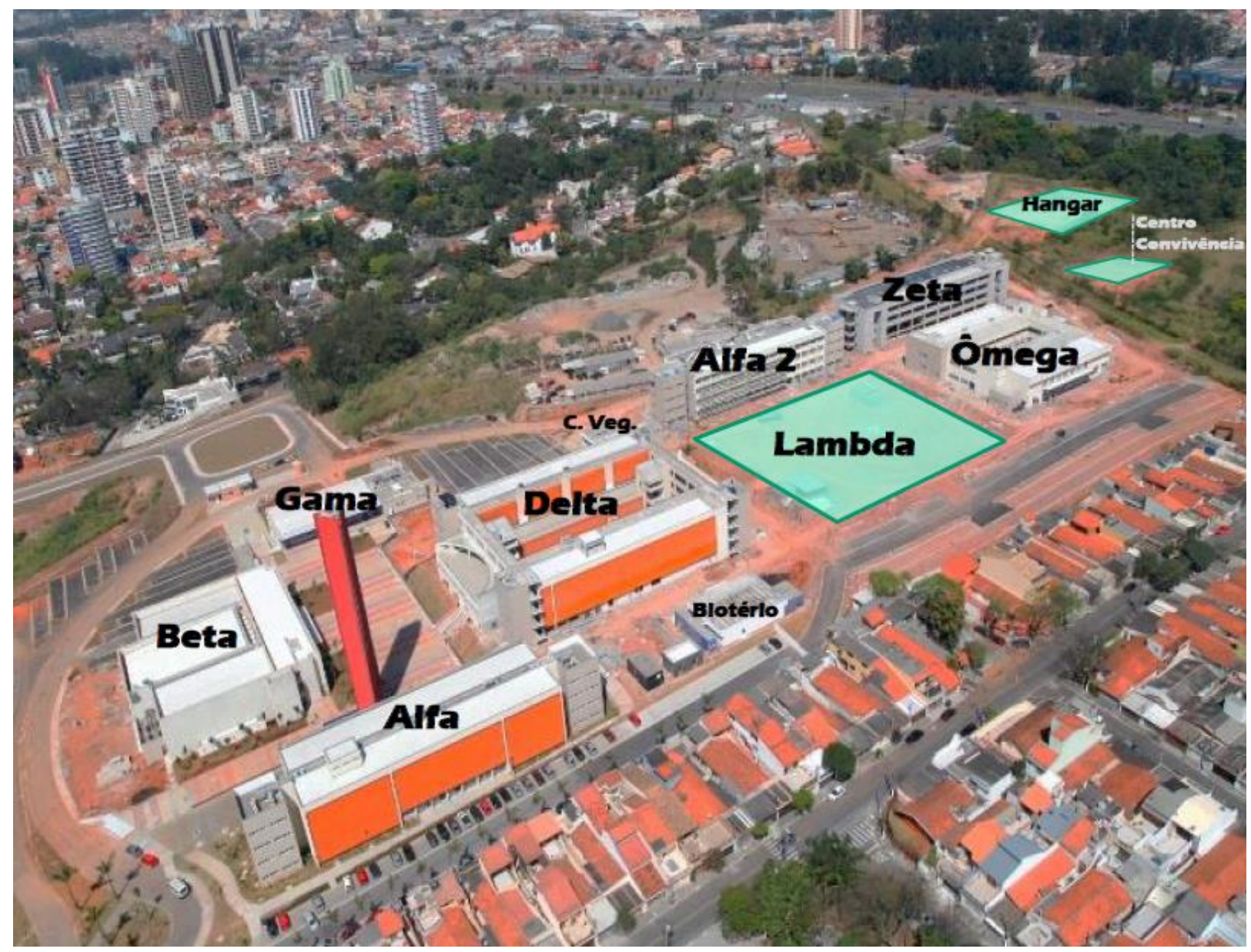

IMAGEM 91 Foto aérea do campus São Bernardo, indicando as futuras ampliações.

Fonte: http://www.pdi.uema.br/ acesso em 15/01/2017 


\section{CONSIDERAÇÕES FINAIS}

Os modelos de universidades apresentados demonstram que o sucesso da implantação de um projeto coletivo depende de um contexto social, político e econômico resultantes de decisões e de embates entre interesses de diversos grupos e agentes urbanos. "É a cidade, contudo, e sua relação com o objeto, que atesta a obra arquitetônica, pois é ela quem dá mensura de seu impacto social, de seu valor urbanístico e de sua contribuição à memória" (MONTANER, 2007, p. 28). Revisitar a implantação da Universidade Federal do ABC, após 12 anos de sua criação, consiste em resgatar certos contextos, para que o pano de fundo de sua origem seja preservado.

Tal como a Universidade de Brasília foi a seu tempo, a UFABC é entendida neste trabalho como um ponto de inflexão na curva das descontinuidades e colapsos a que foram submetidas as universidades brasileiras. E o que resta destacar nesta conclusão, para a disciplina arquitetônica, são seus aspectos formais, para aproximá-la das relações entre forma e ideologia.

A Universidade Federal do ABC configura-se como uma forma urbana complexa, na qual se diluem os limites entre arquitetura e urbanismo, dadas as relações resultantes entre o lugar e o entorno, constituindo-se em sistemas de objetos. Seus campi estão consolidados, porém ainda em construção, devido à atual escassez de recursos que atinge o destino de seus espaços físicos; ou continuamente em construção, como convém a uma universidade implantada no século XXI, o século do conhecimento, cujo conceito básico é preparar a comunidade a construir continuamente seu conhecimento.

Em que pese o apoio do aporte de investimentos recebidos do governo federal, a UFABC contou com outros benefícios que Ihe dão destaque: seu inovador projeto pedagógico, sua localização em uma região ainda pujante economicamente, uma população ansiosa e orgulhosa por receber uma universidade pública, equipes comprometidas com o êxito de sua implantação etc. e cujo caráter multicampi permitiu duas experiências urbanas distintas em relação aos espaços universitários. 


\subsection{Campus Santo André - 2005}

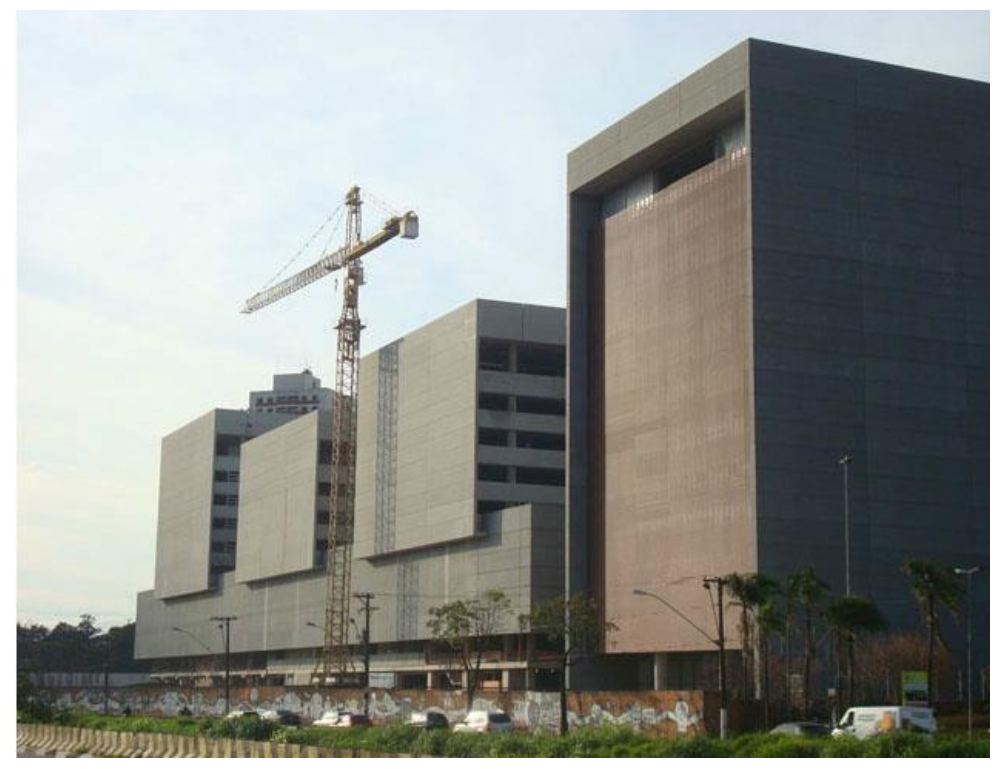

IMAGEM 92 Vista Bloco B e Bloco A. Foto: UFABC 2012
O projeto do campus de Santo André, selecionado por meio de Concurso, teve a responsabilidade de dar significado a vários anseios. Entre eles, simbolizar a grandeza econômica da região e manifestar-se como um novo motor de desenvolvimento, garantindo novos contornos econômicos, apesar da desindustrialização, revigorando o projeto Eixo Tamanduatehy. Seu caráter monumental tornaria pública

a relevância da educação superior para aquele contexto político, anunciando uma nova universidade, com novo projeto pedagógico, voltada para o século XXI.

Ao selecionar o projeto do escritório LibeskindLlovet, o júri garantiu o atendimento das expectativas elencadas acima. Em primeira aproximação, como sistema arquitetônico, o projeto selecionado, marcadamente autoral, distingue-se pela unidade, identidade e monumentalidade. Os arquitetos optaram por uma solução de inserção urbanística muito original. Todas as outras 49 equipes concorrentes tomaram como referência para a implantação do conjunto a Avenida do Estado e o Rio Tamanduateí. O projeto LibeskindLlovet, ao contrário, utilizou-se do paralelismo à ferrovia o que conferiu ao projeto uma característica organizadora do tecido urbano, evitando a obviedade da relação com

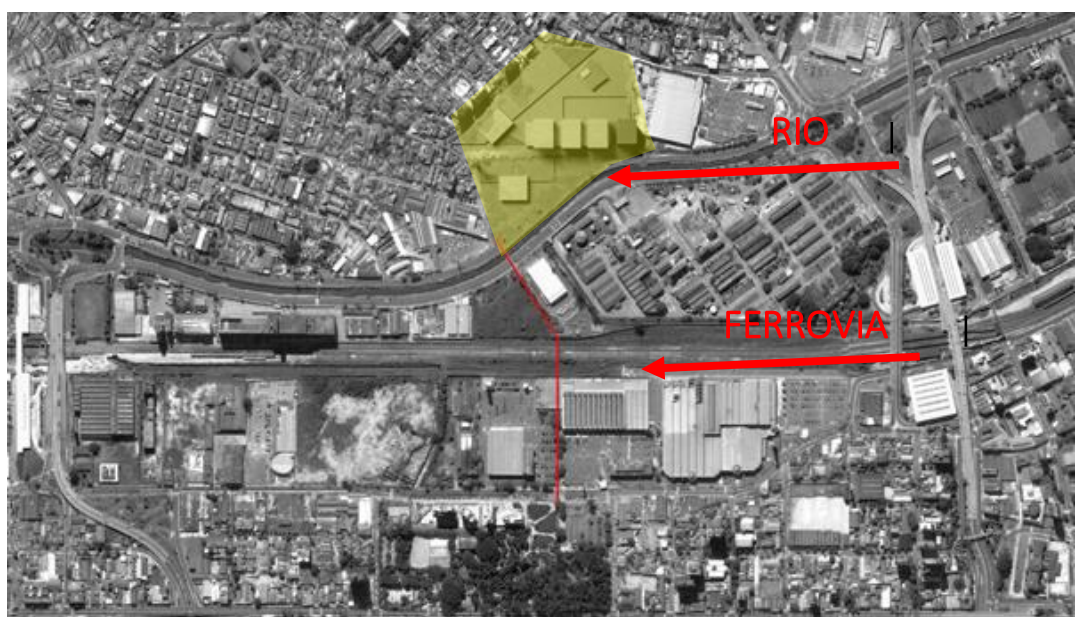

IMAGEM 93 Foto aérea com maquete do projeto vencedor e eixos de implantação Fonte: LibeskindLlovet, 2005

o entorno imediato. 
Com isso a influência do projeto foi além, abraçando e integrando uma porção da cidade (os vazios urbanos entre a ferrovia e o Rio) oferecendo, para o futuro, opções de maior integração e permeabilidade com a cidade.

Faço aqui um parêntese para relatar que, desde a doação da área pela Prefeitura de Santo André, toda a extensão do terreno é circundada por um muro em alvenaria de 2 metros de altura. Nos 12 anos de construção do campus Santo André, o muro continua a existir. Acredita-se que será demolido ao termino das obras, quando se poderá avaliar a tão almejada inserção urbana. Para os transeuntes, não é oferecida uma visão totalizada do conjunto arquitetônico. Ao contrário, por ora, a universidade apresenta-se enclausurada em si mesma.

Seus resultados construtivos advêm de uma solução estrutural formada por eixos de 10x10 metros, com lajes tipo colmeia moldada in loco (durante a obra o sistema construtivo moldado in loco foi substituído por lajes em painéis pré-fabricados imitando a colmeia). Ao contrário do resultado da solução estrutural, bastante criticada, o uso de pré-fabricados na fachada agregou unidade urbanística ao conjunto. Usado em duas cores, ele confirma uma composição e define uma tipologia.

Em relação aos galpões do Matadouro Municipal, cujo uso o Edital colocava como facultativo, os arquitetos esclarecem que sempre consideraram sua permanência. Foi uma decisão inteligente associar a ideia do matadouro com alimento, refeição refeitório. Porém a arquitetura proposta por eles, hoje consolidada, não resultou satisfatória. A opção por "mimetizar" o edifício com as mesmas cores dos grandiosos volumes desvalorizou sua preexistência. (Ver Imagem 62, página 89). No entanto, ao analisar o matadouro como pertencente a um sistema de objetos, de fato ele adquire uma certa independência em relação ao conjunto, destacando-o, conforme propõe o livro O Sistema dos Objetos:

Os signos que os objetos antigos ostentam podem ser entendidos como indícios culturais do tempo, ainda que sejam indícios alegóricos, configurando uma contradição funcional que, de certo modo, acaba se integrando na lógica do sistema. Com um ar de estar sobrando, o objeto antigo também não é meramente decorativo: "não servindo para nada, serve profundamente para qualquer coisa"-é vivido assim de outra maneira, como presença autêntica, isto é, com uma menor dependência para com outros objetos e expressando-se como totalidade. (BECCARI Apud BAUDRILLARD, 2010)

Outro elemento bastante relevante para a compreensão da geometria dos volumes e espaços da UFABC como sistema arquitetônico e, determinante para que LibeskindLlovet conquistasse o prêmio, foi a relação estabelecida entre o partido arquitetônico e o programa 
de necessidades, moldado a partir do projeto pedagógico proposto pela Comissão de Implantação. Conhecido como Bloco A, o bloco da graduação, sua área soma $40.000 \mathrm{~m}^{2}$ e seu acesso principal se dá por uma generosa rampa, de 5 metros de largura, de onde se descortina a paisagem característica do Eixo Tamanduatehy: o rio, a avenida, a ferrovia e as grandes glebas industriais. Ao ascender a rampa, o aspecto monumental do conjunto arquitetônico proporciona ao usuário uma vivencia muito particular: a consciência da relação entre a escala humana e a escala urbana.

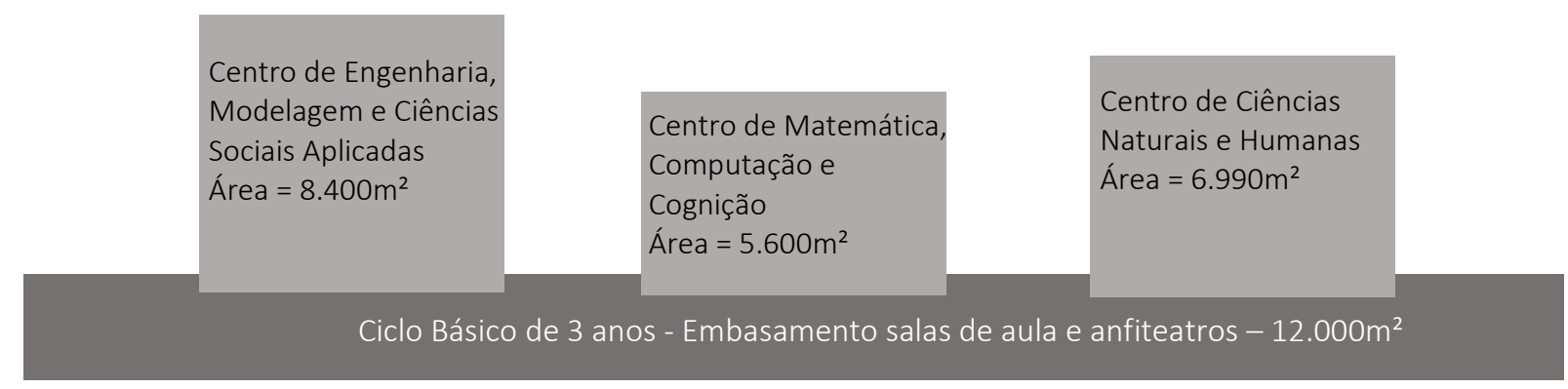

IMAGEM 94 Diagrama de ocupação do Bloco A

Contudo, a perfeita correspondência entre forma e função alcançada no projeto arquitetônico que o fez merecer a premiação traz consigo um grande paradoxo ao confrontarse com os anseios futuros de uma universidade. Os elementos volumétricos utilizados por LibeskindLlovet para simbolizar o projeto pedagógico da UFABC, na verdade, o engessa. Não é categórico que, no futuro, a UFABC não demande novos centros de conhecimento. Não apenas por resoluções internas, mas também para acompanhar a evolução da ciência na permanente construção do conhecimento. Aliás, parece-me que hoje a UFABC já vive esse conflito, que foi relativamente minimizado com a implantação do campus São Bernardo.

O fato é que todo programa de necessidades, mesmo ancorado em um projeto pedagógico, é subjetivo, principalmente para os complexos espaços universitários. A tipologia proposta é resultante da apropriação adequada que o arquiteto faz do programa arquitetônico e isso depende de sua experiência e personalidade, que darão forma funcional e expressiva às tipologias. Dado que essas formas são, ao final, consideradas no processo histórico como "testemunhos de uma época e de sua cultura, afirma-se a relação sociedade/artista pela qual o artista atua em uma situação social existente, mas ao mesmo tempo, contribui com sua obra para formar essa sociedade e caracterizá-la" (TEDESCHI, 1972, p. 50). 


\subsection{Campus São Bernardo - 2008}

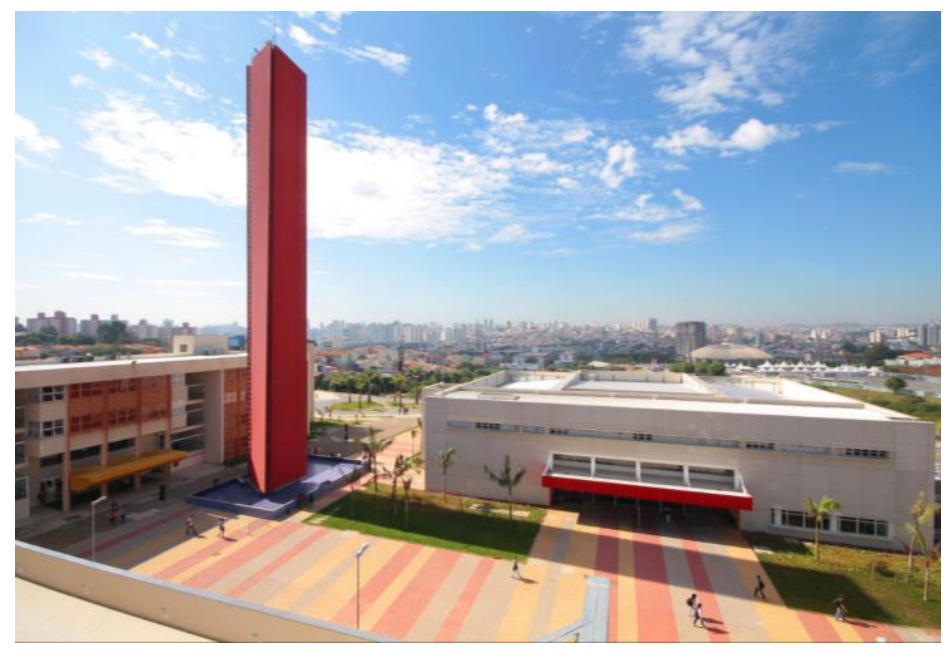

IMAGEM 95 Vista Bloco Alfa à esquerda e Bloco Beta. Foto: Benno Perelmutter Arq e Planej.
Como segundo exemplo de universidades como sistemas arquitetônicos, a implantação do campus da UFABC em São Bernardo se deu em um contexto bastante diverso daquele de Santo André. O terreno foi comprado pelo MEC, o porte do empreendimento foi menos ambicioso - 2.000 alunos - e o seu projeto arquitetônicourbanístico foi contratado por meio

de licitação na modalidade Concorrência, conforme já visto no subcapítulo 2.8.

Seu programa de necessidades foi desenvolvido com uma comunidade acadêmica já consolidada, em um processo participativo abrangendo dirigentes, funcionários e grupos de docentes, que pleiteavam espaços físicos para suas pesquisas, dado que o campus Santo André já apresentava uma demanda reprimida de laboratórios de pesquisa. O professor Bevilacqua repetiu várias vezes que a construção do campus Santo André era como trocar o pneu de um carro em movimento. Já o campus São Bernardo, livre de pressões políticas e com prazos mais dilatados para recebimento de alunos, permitiu um planejamento cuidadoso e uma implantação mais tranquila.

As diretrizes para o campus São Bernardo foram: horizontalidade, integração com a natureza, sustentabilidade, existência de uma praça de acesso aos principais edifícios envolvendo a graduação, adoção de uma escala dos edifícios não monumental e confortável à escala humana, adoção de edifício modular, desarticulação dos volumes, para viabilizar suas construções em etapas, de forma independente, sem conflitos de fluxos com as atividades acadêmicas.

Em relação à inserção urbana, o campus São Bernardo está encravado, ao norte e ao sul, entre dois bairros residenciais. A oeste, há um oleoduto da Petrobras, cortando o terreno, e a Via Anchieta como limites. Embora localizado em uma região central do município, sua conformação geográfica não permite uma integração imediata com a cidade. É um campus 
naturalmente isolado, relativamente segregado da vida urbana e sem uma visibilidade aparente.

A organização de seu sistema viário, periférico para veículos, abraça todos os edifícios, protegendo-os, assim como a via de circulação de pedestres e a ciclovia, de forma racionalizada.

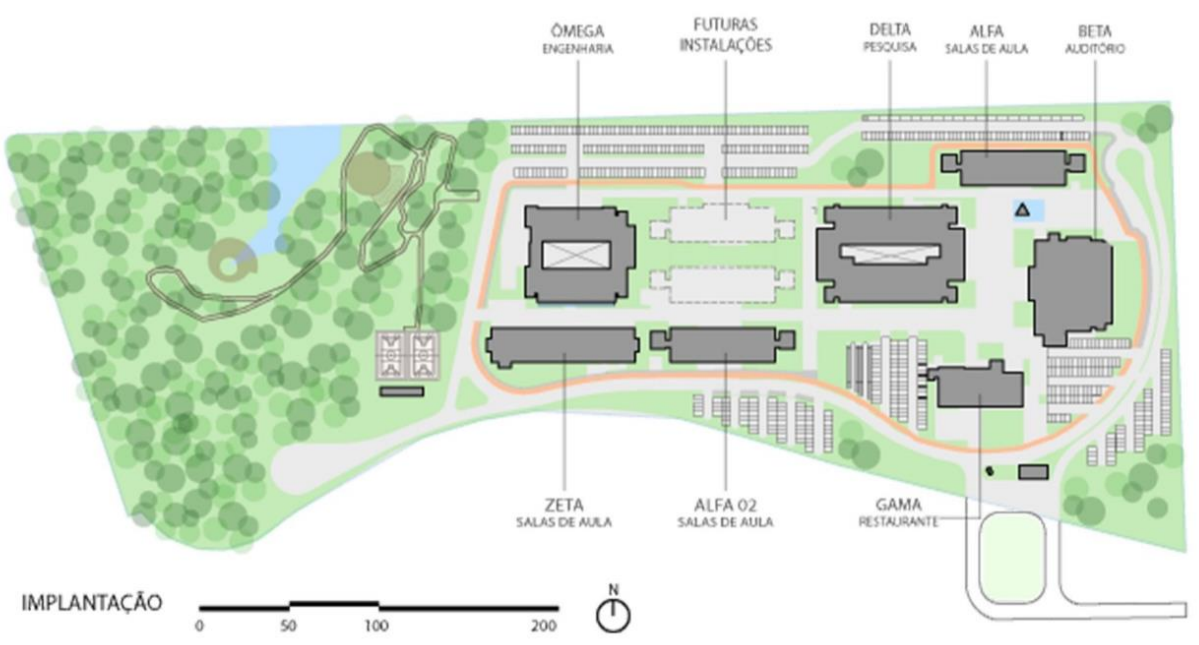

IMAGEM 96 Implantação campus São Bernardo.

Fonte Benno Perelmutter Arq e Planej.

Seus edifícios autônomos e desarticulados, segundo distintas funções, acomodam-se no terreno de forma escalonada, dado o aclive de $10 \%$ na porção longitudinal do terreno. É um campus agradável, convidativo às caminhadas e muito silencioso, condições adequadas para o estudante ou acadêmico que se dedica ao estudo das ciências, segundo alguns dirigentes.

Um dos valores destacáveis do projeto do escritório Benno Perelmutter é a existência da praça, logo na chegada ao campus, que tem, além da função de reunir as pessoas, a de ser, também, o elemento de articulação entre os edifícios, com destaque para o edifício Beta, que contém a biblioteca, o auditório e os anfiteatros ocupando uma posição central. No grande hall de entrada do edifico Beta, há uma cafeteria, com acesso visual para a praça, que é hoje o ponto de encontra da comunidade acadêmica.

O projeto paisagístico não foi ainda executado, no entanto, a praça já está definitivamente consolidada. Ela nada mais é do que um piso. Um piso em elementos de concreto pré-fabricados, intertravados, em diversas cores. Uma solução simples, mas de grande inteligência, que deu movimento e vida a um espaço talvez um pouco acanhado para uma praça que se pretendia como o centro do campus. Isto mostra como a escolha dos materiais adequados é determinante para um empreendimento público, de forma a garantir sua durabilidade e ainda imprimir uma qualidade subjetiva ao espaço, diferenciando-o. 
Edifícios que foram erguidos por várias construtoras, como é o caso do campus Santo André, dificilmente mantêm um padrão de qualidade homogêneo, a menos que o projeto executivo seja detalhado com eficácia para garantir a qualidade das construções, como ocorreu em São Bernardo. Na realidade, a unidade urbanística do campus foi alcançada pela escolha apurada dos materiais, tornando o ambiente universitário alegre e acolhedor, a ponto de os estudantes o chamarem de campus São Berlove.

Mas, se a unidade urbanística foi alcançada até agora, este aspecto demandará cuidados no futuro, na expansão do campus. Do ponto de vista dos investimentos do governo federal, a crítica recorrente à implantação do campus São Bernardo é a de que, para o alto valor pago pelo terreno, seu potencial construtivo foi pouco utilizado, com uma alta taxa de ocupação, em consequência da horizontalidade almejada. Hoje é um campus com poucas possibilidades de expansão, exceto pela área reservada para expansão entre os blocos Delta e Ômega, onde se cogitava um edifício verticalizado para tirar maior proveito do potencial construtivo do terreno, o que, de fato, representa uma boa solução para a gestão dos espaços físicos versus investimentos, desde que garantida a unidade arquitetônica e urbanística do conjunto.

\subsection{Conclusão}

Ao analisar os dois campi da Universidade Federal do ABC como sistemas arquitetônicos contemporâneos, na perspectiva de Montaner, esta dissertação procurou estabelecer relações da parte com o todo e do todo com as partes, em seus aspectos sócio-políticos e em seus aspectos formais. Apesar das fragilidades do repertório teórico, este percurso foi possível em razão da experiência vivenciada na construção dos campi da UFABC. Ainda que com um olhar devotado, porém crítico, somos de opinião que a manutenção desses espaços universitários enquanto sistemas arquitetônicos só se viabilizará mediante o equilíbrio entre o todo e as partes.

Para alcançar tal estabilidade, e correndo riscos de pauperizar o conceito, concluímos que as instituições públicas universitárias devem atentar-se à sustentabilidade de gestão, o que significa enfrentar a equação que se interpõe aos seus conjuntos arquitetônicos: otimização dos espaços físicos $X$ otimização dos recursos humanos $X$ racionalização dos equipamentos $X$ atitudes coletivas. A atividade-fim da UFABC é ensino e pesquisa. E o reconhecimento final de uma instituição é o sucesso das pesquisas que desenvolve. A implantação de laboratórios 
multiusuários deve ser incentivada, pois é possível compartilhar equipamentos, espaços físicos, técnicos de laboratórios e funcionários. É isto que denominamos como sustentabilidade de gestão. Mesmo reconhecendo a influência das novas tecnologias que cada vez mais relativizam a necessidade de proximidade física, é necessário oferecer um ambiente colaborativo, funcional, eficiente e, principalmente, atraente ao pesquisador incentivando-o a trabalhar coletivamente. Decerto que tal atitude representaria uma economia, mas, por hora, em tempos nebulosos, isso não é relevante. Relevante é que hoje existem formas mais contemporâneas de integração acadêmica e temos que lutar por elas.

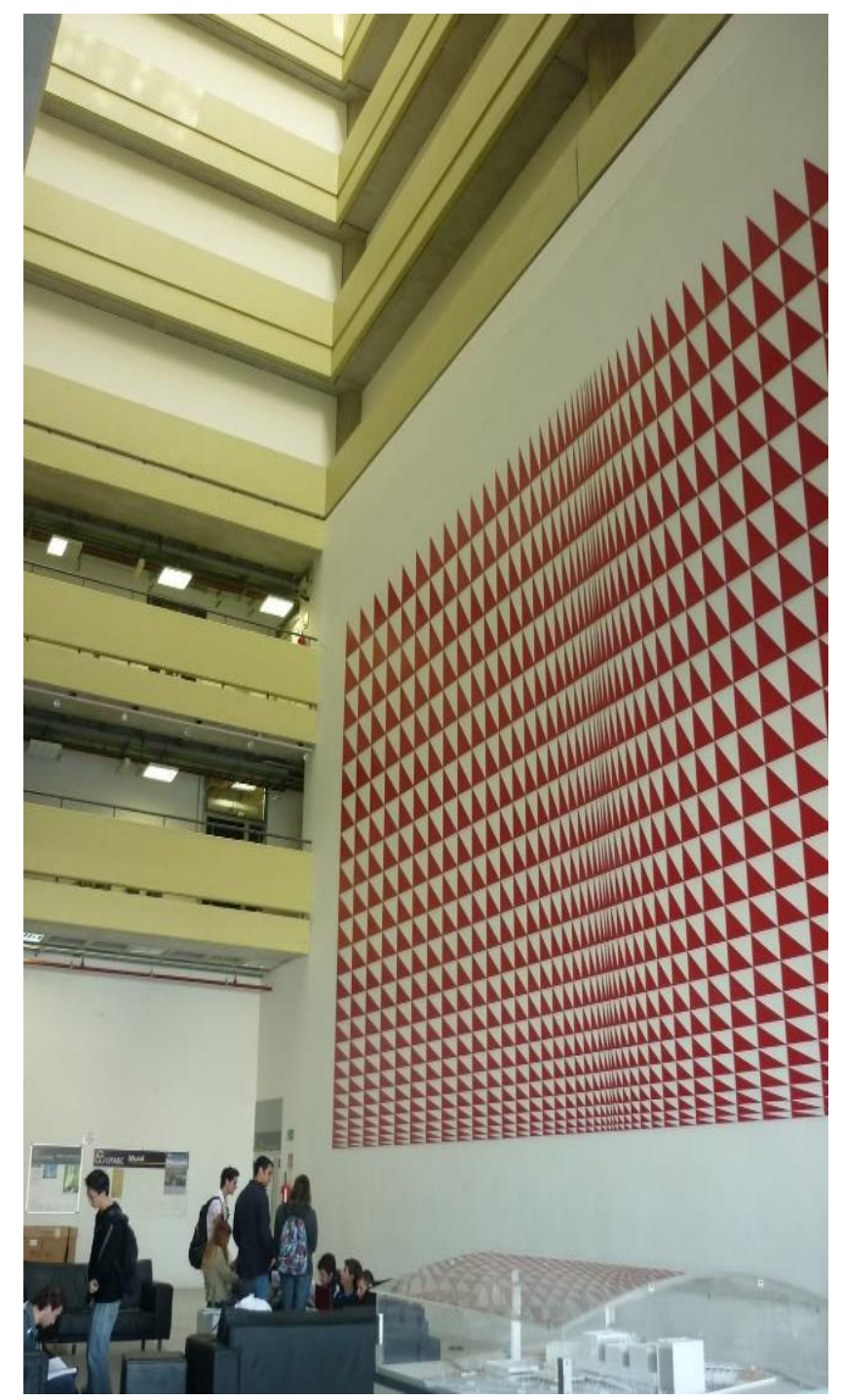

IMAGEM 97 Obra de Luiz Sacilotto no Bloco B
Evidentemente, a arquitetura não prescinde, para sua realização, das âncoras na realidade política, social e histórica, nem sua compreensão é possível isolada de onde, quando e pelas mãos de quem nasceu. Mas, ainda que seja criatura de um contexto, a arquitetura segue existindo como fato artístico, parcialmente transcendendo seu berço; segue existindo em si própria, mesmo quando é naturalmente modificada pelo suceder dos tempos. (ZEIN, 2006). 
IMAGEM 1 A riqueza acumulada das universidades americanas 8

IMAGEM 2 ABC PAULISTA (Sudeste) - inserido na RMSP. 9

IMAGEM 3 Sorbonne, Paris - Foto de Willy Ronis, 1968. 14

IMAGEM 4 Maquete da Universidade Livre de Berlim e desenhos de Shadrach Woods, 1969. 15

IMAGEM 5 Diagramas das obras de Le Corbusier, Mies Van der Rohe, I.M. Pei. 16

IMAGEM 6 Freie Universitat Berlin. , 17

IMAGEM 7 Acesso e pátios - Freie Universitat Berlin. 17

IMAGEM 8 Capa da revista Ad'A 137, 1968. 18

IMAGEM 9 Residências estudantis projetadas por Giancarlo De Carlo em Urbino 20 IMAGEM 10 Residências Estudantis Urbino. 21

IMAGEM 11 Croquis da implantação da Universidade da Calábria. 22

IMAGEM 12 Vista da Universidade da Calabria. 22

IMAGEM 13 UNICAL - Via ponte. 22

IMAGEM 14 Mapa dos países que aderiram ao Processo de Bolonha. 25

IMAGEM 15 Plano de Urbanização da Universidade de Brasília, Lucio Costa, 1962.

IMAGEM 16 Estudo urbanístico campus UnB, 1969

IMAGEM 17 Vista do Instituto Central de Ciências - ICC __ 29

IMAGEM 18 Tabela da expansão das IFES.___ 33

IMAGEM 19 Novas IFES. __ 34

IMAGEM 20 Mapa da rede de expansão de ensino superior. ___ 37

IMAGEM 21 Gráfico do crescimento de vagas e matrículas na graduação nas universidades federais. ___ 37

IMAGEM 22 A Região Metropolitana de São Paulo, com o município de Santo André. ___ 41

IMAGEM 23 Perímetro do projeto Eixo Tamanduatehy. ___ 42

IMAGEM 24 Vista aérea do Eixo Tamandauatehy.___ 43

IMAGEM 25 Proposta de Eduardo Leira para nova centralidade a partir de nova estação ferroviária. ___ 44

IMAGEM 26 Proposta de ligação inter-regional. ___ 44

IMAGEM 27 Desenho elaborado pela equipe de Busquets.

IMAGEM 28 Parque Linear proposto por Busquets. ___ 45

IMAGEM 29 Croquis de Christian de Portzamparc demonstrando a eficiência da quadra aberta. ___ 46

IMAGEM 30 Maquete da ocupação proposta por C. de Portzamparc___ 47

IMAGEM 31 Proposta de ocupação da Quadra Aberta, por C.de Portzamparc. ___ 47

IMAGEM 32 Proposta Candido Malta para novas centralidades e no detalhe. ___ 48

IMAGEM 33 Empreendimentos realizados do Eixo Tamanduatehy, no período de 2000-2007.___ 50

IMAGEM 34 Localização da área da UFABC - Campus Santo André, no Eixo Tamanduatehy.. ___ 51

IMAGEM 35 Foto aérea do terreno para implantação da UFABC.. __ 51

IMAGEM 36 Detalhe de vista aérea de Santo André. Década de 1940.___ 52

IMAGEM 37 Matadouro Municipal em 1915.___ 53 
IMAGEM 38 Vista do antigo Matadouro. 53

IMAGEM 39 Posto de Combustível 53

IMAGEM 40 Diagrama explicativo do progresso do aluno na UFABC. 57

IMAGEM 41 Quadro informativo das fases de implantação do Campus Santo André. 60

IMAGEM 42 Diagrama do programa de necessidades da UFABC. 63

IMAGEM 43 Lista dos arquitetos participantes do Concurso para Projetos Arquitetônicos da UFABC. 65

IMAGEM 44 Sandra Llovet e Cláudio Libeskind. . 66

IMAGEM 45 Fotos da maquete. . 67

IMAGEM 46 Vista superior da maquete da proposta e os Eixos de Acesso. . 67

IMAGEM 47 Cortes e elevações. 68

IMAGEM 48 Plantas de Implantação. 70

IMAGEM 49 Perspectivas 70

IMAGEM 50 Arq. Paulo Henique Paranhos. 70

IMAGEM 51 Proposta do arquiteto Paulo Paranhos. 71

IMAGEM 52 Fotos da maquete de Implantação. 71

IMAGEM 53 arqts. Marcelo Morettin e Vinicius Andrade.. 73

IMAGEM 54 Proposta Andrade Morettin - Painel 1. 74

IMAGEM 55 Proposta Andrade Morettin - Painel 2. 75

IMAGEM 56 Proposta Andrade Morettin - Painel 3. 75

IMAGEM 57 Proposta Andrade Moretin - Painel 4. 76

IMAGEM 58 Proposta Andrade Moretin - Painel 5. 76

IMAGEM 59 Renato e Lilian Dal Pian. 77

IMAGEM 60 Proposta de implantação. 78

IMAGEM 61 Vista da Praça Congregadora. 78

IMAGEM 62 Imagens da Proposta 79

IMAGEM 63 Implantação, Perspectiva e Cortes. . 81

IMAGEM 64 Maquete do campus Santo André e o conceito do projeto. 83

IMAGEM 65 Fotos da obra - Bloco A e refeitório, antigo Matadouro Municipal. ___ 84

IMAGEM 66 Diagrama Projeto Arquitetônico X Projeto Pedagógico___ 84

IMAGEM 67 Vista Bloco A e Bloco B.___ 85

IMAGEM 68 Localização dos terrenos para o campus São Bernardo. ___ 86

IMAGEM 69 Foto aérea do terreno do campus São Bernardo. ___ 87

IMAGEM 70 Diagrama UFABC - Áreas do Conhecimento. ___ 89

IMAGEM 71 Orientações do prof. Bevilacqua para a Coordenação Técnica. . ___ 91

IMAGEM 72 Croquis prof. Bevilacqua para o Núcleo de Cognição ___ 91

IMAGEM 73 Estudo de viabilidade desenvolvido pela coordenação técnica do campus São Bernardo. ___ 93

IMAGEM 74 Benno Perelmutter e Marciel Peinado.___ 94

IMAGEM 75 Proposta n. 2 do estudo de implantação aprovada pela equipe dirigente. ___ 95 
IMAGEM 76 Proposta 3 Implantação Campus São Bernardo. 95

IMAGEM 77 Projeto definitivo de implantação do campus São Bernardo. 96

IMAGEM 78 Foto da maquete campus São Bernardo vista norte. 97

IMAGEM 79 Foto maquete campus São Bernardo vista sul. 97

IMAGEM 80 Bloco Alfa Térreo. 98

IMAGEM 81 Primeiro Pavimento 98

IMAGEM 82 Segundo Pavimento 98

IMAGEM 83 Terceiro Pavimento 98

IMAGEM 84 Bloco Beta Térreo 99

IMAGEM 85 Bloco Beta Primeiro Pavimento 99

IMAGEM 86 Bloco Gama refeitório planta e elevação 100

IMAGEM 87 Bloco Delta Térreo 101

IMAGEM 88 Bloco Delta 1‥ Pavimento 101

IMAGEM 89 Bloco Delta 2‥ Pavimento 101

IMAGEM 90 Bloco Ômega 102

IMAGEM 91 Foto aérea campus São Bernardo indicando as futuras ampliações. 104

IMAGEM 92 Vista Bloco B e Bloco A. 106

IMAGEM 93 Foto aérea com maquete do projeto vencedor e eixos de implantação. 106

IMAGEM 94 Diagrama de ocupação do Bloco A 108

IMAGEM 95 Vista Bloco Alfa à esquerda e Bloco Beta. 109

IMAGEM 96 Implantação campus São Bernardo. 110

IMAGEM 97 Obra de Luiz Sacilotto no Bloco B 112 


\section{REFERÊNCIAS}

ACADEMIA BRASILEIRA DE CIÊNCIAS. Subsídios para a Reforma do Ensino Superior. 2004. Disponível em: http://www.abc.org.br/IMG/pdf/doc-29.pdf. Acesso em: 27/05/2016.

ALBERTO, K. C. Interfaces brutalistas: megaestruturas universitárias. In: X Seminário Docomomo. Curitiba, 2013.

A noção de integração universitária nos campi das universidades de Brasília e de Campinas - Duas interpretações de um mesmo ideal. Ano 06, fev.2006.

Disponível em: http://www.vitruvius.com.br/revistas/read/arquitextos/16.184/5684. Acesso em: 21/05/2017.

ANDIFES. Proposta de expansão e modernização do sistema público federal de ensino superior encaminhada ao Senhor Presidente da República Luiz Inácio Lula da Silva pela ANDIFES. Disponível em:

http://www.andifes.org.br/wp-content/files flutter/1363027779Proposta expansao Lula.pdf Acesso em 26/05/2016.

ANDRADE, C. R. \& PAVESI, Alessandra. O Planejamento de campi universitários como prática participativa e educativa. In: Revista Brasileira de Estudos Urbanos e Regionais. V. 14, N.1, 187196, maio de 2012.

Prefácio. In: PINTO, G. Arquitetura e Educação - Câmpus Universitários Brasileiros. São Carlos: EdUFScar, 2009, p. 11-13.

ARANTES, O., VAINER, C., \& MARICATO, E. A cidade do pensamento unico: desmanchando consensos. Petrópolis: Vozes, 2000.

ARGAN, G. C. História da arte como história da cidade. São Paulo: Martins Fontes, 1998.

ATCON, R. P. Manual sobre o planejamento integral do Campus Universitário. Florianópolis: CRUB/UFSC, 1970

BAMPI, Aumeri Carlos; DIEL, Jeferson Odair. O modelo multicampi de universidade e suas relações com a sociedade. 2013. Disponível em: https://repositorio.ufsc.br/bitstream/handle Acesso em: 22/06/2016

BECCARI, Marcos. Resenha: O Sistema dos Objetos. 2010. Disponível em: http://filosofiadodesign.com/resenha-o-sistema-dos-objetos/ Acesso em: 16/01/2017. BENEVOLO, L. A Arquitetura no novo milenio. São Paulo: Estação Liberdade, 2007. BEVILACQUA, L. História da UFABC . (G. e. Stiubiener, Entrevistador). 25 de novembro de 2014. 
UFABC e o Campus São Bernardo. Artigo de 27 de março de 2008. Disponível em: http://www.ufabc.edu.br/artigos/ufabc-e-o-campus-sao-bernardo-867. Acesso em: 23/05/2017.

BIANCHETTI, L., \& MAGALHÃES, A. Declaração de Bolonha e internacionalização da educação superior: protagonismo dos reitores e autonomia universitária em questão. In: Avaliação. Campinas, 2015, vol. 20, n.1, p. 225-249.

BRASIL. A democratização e expansão da educação superior no país 2003-2014. Disponível em: http://portal.mec.gov.br/index.php?option=com docman\&view=download\&alias=16762balanco-social-sesu-2003-2014\&Itemid=30192 Acesso em: 27/05/2016. . Análise sobre a Expansão das Universidades Federais: 2003-2012. Rel. Comissão MEC Brasília, 2012a. Disponível em: http://portal.mec.gov.br Acesso em: 26/05/2016. . Balanço Social SESU 2003 a 2014. Brasília: Simec/MEC, 2014. Disponível em: http://portal.mec.gov.br/ Acesso em 12/08/2016. . Haddad atende todos os níveis de educação. Brasília, 2012b. Disponível em: http://portal.mec.gov.br Acesso em: 26/05/2016. . Lei no 10172/2001. Disponível em: http://portal.mec.gov.br/arquivos/pdf/L10172.pdf Acesso em: 26/05/2016. . Lei n¹1.145/2005. Institui a Fundação Universidade Federal do ABC - UFABC e dá outras providências. Brasília, 2005. Disponível em:

http://www.planalto.gov.br/ccivil_03/_ato2004-2006/2005/lei/l11145.htm Acesso em: 23/05/2017.

. MEC lança concurso para projeto arquitetônico da UFABC. 31 de outubro de 2005.

Disponível em: http://portal.mec.gov.br/busca-geral/212-noticias/educacao-superior$1690610854 / 4693-s p-109011493$ Acesso em 15/01/2016.

. Programa de Metas do Presidente Juscelino Kubitschek. Rio de Janeiro: Dto. Imprensa Nacional, 1958.

Projeto de Lei 3962/2004. Institui a Universidade Federal do ABC - UFABC e dá outras providências. Brasília, 2004. Disponível em:

http://www.camara.gov.br/proposicoesWeb/fichadetramitacao?idProposicao=260797 Acesso em: 23/05/2016.

CALVO-SOTELLO, P. C. European University - American Campus: bridges between cultures. . In: L. COOKE, Frontiers in Higher Educacion. New York: New Science Publishers, 2007, p. 31-63. 
CANELLA, G. Passé et avenir de anti-ville universitaire. In: L'Architecture d'Aujoud'hui. Paris: 1968, p. 16-19.

CASTELLANOS, R., DOMINGO, D., \& TORRES, J. Los mat-buildings y las universidades de los 60. In: DPA: documents de projectes d'arquitectura. Universitat Politècnica de Catalunya, n. 27-28, 2011, p. 46-51: Disponível em: http://hdl.handle.net/2099/14189 Acesso em: 24/05/2017. CASTILHO, F. O conceito de universidade no projeto da Unicamp. Campinas: Unicamp, 2008. CHARLE, C., \& VERGER, J. Histoire des Universités. Paris: PUF, 1994.

CUNHA, L. A. A universidade: modernizada, amordaçada e privatizada. In: CUNHA, L. A. \& GOÉS, M. O golpe na educação. Rio de janeiro: Zahar, 1988, p. 87.

DAVIES, C. Reflexiones sobre La arquitectura. Londres: Editorial Reverté, 2011.

DE CARLO, G. La piramide rovesciata. Bari: De Donato, 1968. . Nelle città del mondo. Veneza: Marsilio Editori, 1988. . Urbino: The history of a city and plans for its developement. Cambridge, Massachusetts: The MIT Press, 1970.

DECLARAÇÃO de Bolonha. Bolonha (Itália), 1999. Disponível em:

http://antigo.ufabc.edu.br/images/stories/pdfs/declaracaodebolonhaportugues.pdf. Acesso em: 16/01/2017.

DENNY, P. Campus - Situating the Global University. 2014. Disponível em: www.phillipdenny.com Acesso em: 27/09/2016.

DOBER, R. P. Campus Plainning. EUA: Reinhold Publishing Corporation, 1963.

EUROPEAN Higher Education Area. Disponível em: http://www.ehea.info Acesso em: $13 / 01 / 2017$

FARIA, D. S., \& MAIA, D. M. Universidade Nova do Brasil e o Processo de Bologna na Comunidade Européia. 2012. Disponível em: Rede Livre: http://flacso.redelivre.org.br. Acesso em: 21/05/2017.

FOSTER, H. O Complexo arte-arquitetura. São Paulo: Cosac Naify, 2015.

FRAMPTON, K. História crítica da arquitetura moderna. São Paulo: Martins Fontes, 1997.

FULIGNA, T. Uma Giornata a Urbino con Giancarlo De Carlo - visitando le sue architetture. Urbino: Arti Grafiche Editoriali, 2001.

FUTAGAWA, Y. University. Revista GA - 05, 2006.

GOMES, C. D. USP Leste - a expansão da universidade do oeste para leste. São Paulo: Edusp, 2005. 
GREGOTTI, V. Territorio e arquitetura. In: NESBITT, K. Uma nova agenda para a arquitetura. São Paulo: Cosac Naify, 2013.

KLEEB, Suzana C. O Matadouro Municipal. Santo André-SP: Museu de Santo André Dr. Octaviano Armando Gaiarsa,2005.

KLINK, J. J. A cidade-região: regionalismo e reestruturação no Grande ABC Paulista. Rio de Janeiro: DP\&A, 2001.

MCKEAN, J. Giancarlo De Carlo - Des Lieux, des hommes. Paris: Centre Pompidou, 2004.

MONEO, R. Inquietud teorica y Estrategia Proyectual. Barcelona: Actar, 2004.

MONTANER, J. M. Arquitetura e Crítica. Barcelona: GG, 2007.

Sistemas Arquitetônicos Contemporâneos. Barcelona: GG, 2009.

MORIN, E. Os sete saberes necessários à educação do futuro. Brasilia, DF: Unesco, 2001.

MUTHESIUS, S. The postwar university: utopianist campus and colleges. London: Yale University Press, 2000.

REVISTA ACRÓPOLE. Ano 31, n.369. São Paulo, 1970. Disponível em: http://www.acropole.fau.usp.br/edicao/369 Acesso em: 24/05/2017.

NEGRELOS, E. P. Novos grandes projetos urbanos na metrópole paulistana. In: Revista Cidades, v.9, n. 16, 32, 2012.

NESBITT, K. Uma nova agenda para a arquitetura. São Paulo: Cosacnaify, 2008.

OLIVEIRA, G. A. Interdisciplinaridade e inclusão social no processo de implantação da UFABC Dissertação de Mestrado: São Paulo, 2010.

PREFEITURA MUNICIPAL DE SANTO ANDRÉ. O futuro já chegou - Eixo Tamanduatehy. Santo André, 1998.

Projeto Tamanduatehy. Santo André, 1999.

PINTO, G. \& BUFFA, E. Arquitetura e Educação - campus universitários brasileiros. . São Carlos: EdUFSCAR, 2009.

PORTAL VITRUVIUS. Concurso para a sede da UFABC. Projetos, São Paulo, ano 06, n. 062.01, 2006. Disponível em: http://www.vitruvius.com.br/revistas/read/projetos/06.062/2612 Acesso em: 22/06/2016.

PORTAS, N. A cidade como arquitetura, apontamentos de método e critica. Lisboa: Horizonte, 1969.

PORTAS, N., \& BARATA, J. A Universidade na cidade - Problemas arquitetônicos e de inserção no espaço urbano. Brasilia: ICa/FAU, 1968. 
RIBEIRO, D. A Universidade de Brasilia. Brasilia: CBPE, 1962.

RISTOFF, D. A universidade brasileira em tempos de contemporaneidade. In. Morosini, M. A Universidade no Brasil: concepções e modelos. Brasilia: INEP, 2006.

RODRIGUEZ, L. A. (2001). Universidade e a fantasia Moderna: a falácia de um modelo espacial unico. Niteroi: EdUFF, 2001.

SAKATA, M. N. Projeto Eixo Tamanduatehy: uma nova forma de intervenção urbana em Santo André? Dissertação de Mestrado - Universidade de São Paulo. São Paulo: FAUUSP, 2006.

SERT, J. L., ROGERS, E., \& TYRWHITT, J. El Corazon de la Ciudad: por una vida más humana de la comunidad. Barcelona: Hoepli, S.L., 1955.

SMITHSON, A. TEAM X - Cadernos del Taller. Buenos Aires: Nueva Vision, 1962.

How to recognise and read mat-building. In: Architectural Design, 1974, p.6-23.

TAFURI, M. Vittorio Gregotti Progetti e architetture. Milano: Electa editrice, 1982.

TEDESCHI, E. Teoría de la arquitectura. Buenos Aires: Nueva Vision, 1972.

TEIXEIRA, A. N. A produção do espaço público no projeto urbano Eixo Tamanduatehy (Santo André-SP). Ano 11, jul. 2010.

Disponível em: Vitruvius: http://www.vitruvius.com.br/revistas/read/arquitextos/11.122/3483 Acesso em: 24/05/2017.

TEMPIA, E. Des universités... Pourquoi? Combien? Pour qui? Oú? Comment? I'Architecture d'Aujourd'hui, 4-9. Paris: 1968.

TRIBUNAL DE CONTAS DA UNIÃO. Acórdão AC-2230-16/14-2. In: Diário Oficial da União, de 28 de maio de 2014.

TURNER, P. V. Campus: an American planning tradition. . Cambridge: MIT Press, 1984.

UFABC. Plano de Logística Sustentável. Disponível em: http://propladi.ufabc.edu.br/desenvolinstitucional/pls Acesso em 13/01/2017.

Projeto Pedagógico. Santo André, 2006. Disponível em:

http://antigo.ufabc.edu.br/index.php?option=com_content\&view=article\&id=21. Acesso em: 09/01/2017.

WAISMAN, M. El interior de la historia: historiografia arquitectónica para uso de latinoamericanos. Bogotá: ESCALA, 1993.

ZEIN, R. V. Breve introdução à Arquitetura Paulista Brutalista. Ano 06, fev. 2006. Disponível em: http://www.vitruvius.com.br/revistas/read/arquitextos/06.069/375 Acesso em:24/05/2017. 
ANEXOS

ANEXO A

DOAÇÃO DO TERRENO EM SANTO ANDRÉ 


\section{Prefeitura Municipal de Santo André}

Gabiriete do Prefeito

Santo André, 01 de agosto de 2005

P.C. $n^{\circ} 763.08 .2005$

Senhor Presidente

Tenho a honra de submeter à elevada apreciação e deliberação dessa Egrégia Câmara Municipal, o incluso Projeto de Lei ${ }^{\circ}$ 022/2005, que dispõe sobre a doação de imóvel à Fundação Universidade Federal do $A B C$ - UFABC, visando sua instalação e operação.

A Fundação Universidade Federal do ABC - UFABC, criada pela Lei Federal ñ ${ }^{\sigma}$ 11.145, de 26 de julho de 2005, vinculada ao Ministério da Educação, com foro e sede na cidade de Santo André, terá como objetivo ministrar educação superior, desenvolver pesquisa nas diversas áreas do conhecimento e promover a extensão universitária, caracterizando sua inserçã̃o regioṇal mediante atuação na região do ABC paulista.

A mensagem do Projeto de Lei no 3.962/2004, do Ministro de Estado do Planejamento, Orçamento e Gestão Guido Mantega e do Ministro de Estado da Educação Tarso Genro, dispõe que a expansão dā rede de ensino superior e aampliação do investimento em ciência e tecnologia são objetivos centrais do governo federal e foco do debate sobre a reforma universitária. A criação de uma grande universidade pública no coração da indústria, na mäior região metropolitana do país, é uma clara demonstração de compromisso com o desenvolvimento, a cultura e a democratização do acesso ao ensino superior. É uma das iniciativas que renovam a confiança do país em si mesmo e têm o poder de mobilizar as novas gerações para a invenção do futuro.

O ABC paulista representou, desde os anos 1950, a vontade de superação do subdesenvolvimento, a industrialização, a energia do empreendimento $e$ as expectativas de progresso e mobilidade social. Mais recentemente, tornou-se parte da história brasileira de afirmação das liberdades e da cidadania, éxpressão do moderno movimento operário e das lutas pela democracia. A reforma universitária começa como deve ser: com investimento público em educação e ciência, inovação institucional e confiança no Brasil.

A UFABC passa a assumir um compromisso com o desenvolvimento e a democracia, aberta a todos os brasileiros, com caracteristicas de uma Universidade Tecnológica para a formação de profissionais de elevada qualificação em áreas estratégicas para o desenvolvimento brasileiro, produção de conhecimento e 


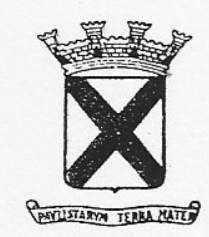

Prefeitura Municipal de Santo André

Gabinete do Prefeito

tecnologia para a indústria, gestão de empresas, políticas públicas e educação básica; de uma Universidade Aberta que utilize tecnologias educacionais e permita o atendimento de um grande número de estudantes, além de ter uma organização curricular flexível que multiplique as oportunidades de formação, e, de uma Universidade Democrática, de gestão participativa com efetiva contribuição de trabalhadores, empresários e organizações não governamentais.

A mensagem destacou ainda que a criação da UFABC trará grandes benefícios para a maior região metropolitana do país. Ampliará a oferta de ensino superior à população e, ao mesmo tempo, gerará conhecimentos científicos e tecnológicos necessários ao desenvolvimento, à prosperidade e ao bem estar da população paulista e brasileira.

Assim, atendendo ao disposto no art. 100 da Lei Orgânica do Município, vem pelo presente projeto alienar, mediante doação, o bem imóvél para viabilizar a instalação e funcionamento da Fundação Universidade Federal do $A B C$ - UFABC.

Sendo assim, aguarda este Executivo venha essa Colenda Câmara acolher e aprovar o incluso Projeto de Lei, convertendo-o em diploma legal, na maior brevidade possível, nos termos do parágrafo $1^{\circ-}$ do artigo 45 da Lei Orgânica do Município.

Ao ensejo, subscrevemo-nos com apreço.

\author{
Excelentíssimo Senhor \\ Luiz Zacarias \\ Presidente da Câmara \\ Municipal de Santo André. \\ apsm . -
}




\section{Laudo de Avaliação}

Interessado: Secretaria de Desenvolvimento Urbano e Habitação

Objetivo: Avaliação de imóvel público

Endereço: Avenida dos Estados · Bairro Bangu

Metodologia: NBR 14653 - Método Comparativo Direto, conforme NBR 5676 (Norma de Avaliação de Imóveis Urbanos)

Classificação Fiscal: 2.04.04.

O presente laudo caracteriza-se pela avaliação do terreno sem considerar as benfeitorias existentes. A Metodologia utilizada, sobretudo em relação à determinação do valor médio por $\mathrm{m}^{2}$ baseia-se na Inferência Estatística com os critérios e ajustes pertinentes, e que é parte integrante do laudo.

\section{1- Características do terreno:}

De acordo com dados de memorial descritivo anexo, o terreno apresenta formato irregular e topografia com declive para os fundos e com as seguintes dimensões:

$323,39 \mathrm{~m}$ - frente para Avenida dos Estados

15,69 m - frente em curva - Avenida dos Estados esquina com Rua Santa Adélia

199,81 m - frente para Rua Santa Adélia

$7,65 \mathrm{~m}$ - frente em curva - Rua Santa Adélia esquina com Rua da Abolição

398,69 m - frente para Rua da Abolição

23,14 m - frente para Rua Oratório

$191,38 \mathrm{~m}$ - lateral direita

Área de $76.951,86 \mathrm{~m}^{2}$

O imóvel está situado em local com todos os melhoramentos públicos.

\section{2- Cálculo do Valor do Terreno:}

De acordo com dados anexos, cujo critério foi a adoção de obter pesquisas de mercado imobiliário com Zona de característica homogênea, que para o cáso é Grupo IV - 10 Zona: Industrial, temos:

\section{Dados:}

\section{Zona de avaliação}

Testada (a) em metros =

Área $\mathrm{em} \mathrm{m}^{2}=$

Fator declividade $(\mathrm{fd})=$

Valor $\mathrm{p} / \mathrm{m} 2$ em FMP $(q)=$

Valor do FMP no mês deReferência=

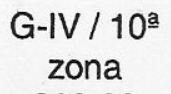

323,39 .

$76.951,86$

0,90

89,85

1,8747
Área de

referência

$5.000 \mathrm{~m}^{2}$

$V t=S \times q \times f d \Rightarrow V t=76.951,86 \times 89,85$ FMP's $\times 1,00 \times 0,90$

$\underline{V t} \equiv \mathbf{6 . 2 2 2 . 7 1 2 , 1 6 ~ F M P ' s ~ o u ~} \mathrm{R} \$ 11.665 .718,48$ 


\section{3-Consideracões Finais:}

Nada mais havendo a informar, os signatários, membros da Comissão Especial de Avaliação do Município de Santo André, dão por encerrado o presente laudo, que consta de (02) duas folhas digitadas apenas no anverso, sendo a última datada e așininada.

Santo André, 29 de Julho de 2005

Uur lealos Vodigues

Arq. Luiz Carlos Rodrigues

Presidente da Comissão Especial de Avaliação

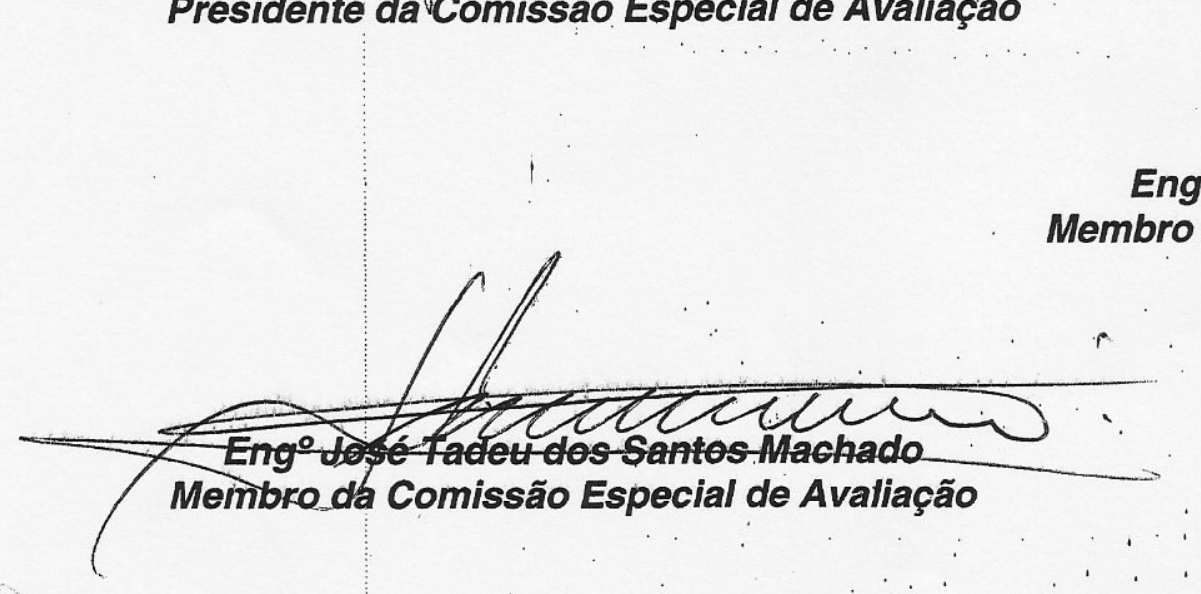









\section{LEI N 8.748, DE 15 DE SETEMBRO DE 2005}

\section{PUBLICADO:}

Diário do Grande ABC N 12623 : 02 DATA 16 / 09 / 05

Projeto de Lei $n^{\circ} 22$, de 01.08.2005 - Proc. n 13.364/2005-9.

AUTORIZA o Executivo Municipal a alienar, mediante doação, imóvel à Universidade Federal do ABC - UFABC.

JOÃO AVAMILENO, Prefeito do município de Santo André, Estado de São Paulo, no uso e gozo de suas atribuições legais,

FAZ SABER que a Câmara Municipal aprovou e ele sanciona e promulga a seguinte Lei:

Art. $1^{\circ}$. Fica o Município autorizado a desafetar e alienar, mediante doação, área pertencente ao município de Santo André, situada entre a Avenida dos Estados e as Ruas Santa Adélia, da Abolição e Oratório - Bairro Bangú - Santo André, com $76.951,86 \mathrm{~m}^{2}$, à Fundação Universidade Federal do ABC - UFABC, criada pela Lei Federal $n^{\circ} 11.145$, de 26 de julho de 2005, conforme descrição do Anexo Único e demais elementos constantes do Processo Administrativo n 13.364/2005-9.

Art. $\mathbf{2}^{\circ}$. A doação de que trata o artigo $1^{\circ}$ efetivar-se-á mediante o aceite pela donatária do encargo de implantar na área doada a Fundação Universidade Federal do $A B C$ - UFABC, no prazo de 5 (cinco) anos, prorrogáveis mediante justificativa devidamente aceita pelo Município.

Art. $3^{\circ}$. Da Escritura de Doação constarão:

I -que cessadas as razões que justifiquem a sua doação, o imóvel reverterá ao patrimônio da pessoa jurídica de direito público interno doadora;

II -cláusula de inalienabilidade do imóvel.

Art. $4^{\circ}$. As Comissões Permanentes de Meio Ambiente, Desenvolvimento Urbano e de Educação e Cultura ficarão incumbidas de acompanhar todo o processo de formação da Universidade Federal do ABC - UFABC, desde o estudo de impacto de vizinhança até o planejamento pedagógico.

Art. $5^{\circ}$. A implantação da Universidade Federal do ABC - UFABC deverá obedecer toda legislação referente à proteção do meio ambiente e do uso e ocupação do solo urbano, sob pena de nulidade da presente doação e reversão do imóvel ao patrimônio do Município, devendo tal condição estar prevista expressamente na escritura pública de doação.

Art. $\mathbf{6}^{\circ}$. Esta lei entra em vigor na data de sua publicação.

Art. $7^{\circ}$. Ficam revogadas as disposições em contrário. 
Prefeitura Municipal de Santo André, em 15 de setembro de 2005.

JOÃO AVAMILENO

PREFEITO MUNICIPAL

MARCELA BELIC CHERUBINE

SECRETÁRIA DE ASSUNTOS JURÍDICOS

CLEUZA RODRIGUES REPULHO

SECRETÁRIA DE EDUCAÇÃO E FORMAÇÃO PROFISSIONAL

ROSANA DENALDI

SECRETÁRIA DE DESENVOLVIMENTO URBANO E HABITAÇÃO

Registrada e digitada no Gabinete do Prefeito, na mesma data, e publicada.

WANDER BUENO DO PRADO

CHEFE DE GABINETE

ANEXO ÚNICO

IMÓVEL DE PROPRIEDADE DO MUNICÍPIO DE SANTO ANDRÉ, CONFORME PLANTAS E DEMAIS ELEMENTOS INSTRUTÓRIOS CONSTANTES DO PROCESSO ADMINISTRATIVO N ${ }^{\circ} 13.364 / 2005-9$, E QUE ASSIM SE DESCREVE:

"Inicia-se no ponto A, localizado no alinhamento predial da Avenida dos Estados. Deste ponto segue em curva à esquerda pelo alinhamento predial da Avenida dos Estados, com desenvolvimento de 138,73m (cento e trinta e oito metros e setenta e três centímetros), até o ponto B; daí, segue no azimute 350¹5'36" pelo alinhamento predial da Avenida dos Estados, numa distância de 184,66m (cento e oitenta e quatro metros e sessenta e seis centímetros), até o ponto $\mathrm{C}$; daí, segue em curva à direita na confluência dos alinhamentos prediais da Avenida dos Estados e Rua Santa Adélia, com desenvolvimento de 15,69m (quinze metros e sessenta e nove centímetros), até o ponto D; daí, segue no azimute $104^{\circ} 54^{\prime} 02^{\prime \prime}$ pelo alinhamento predial da Rua Santa Adélia, numa distância de 117,35m (cento e dezessete metros e trinta e cinco centímetros), até o ponto $\mathrm{E}$; daí, segue em curva à esquerda pelo alinhamento predial da Rua Santa Adélia, com desenvolvimento de $82,46 \mathrm{~m}$ (oitenta e dois metros e quarenta e seis centímetros) até o ponto F; daí, segue em curva à direita pela confluência dos alinhamentos prediais da Rua Santa Adélia e Rua da Abolição, com desenvolvimento de 7,65m (sete metros e sessenta e cinco centímetros) até o ponto G; daí, segue no azimute $172^{\circ} 36^{\prime} 11^{\prime \prime}$ pelo alinhamento predial da Rua da Abolição, numa distancia de 36,01m (trinta e seis metros e um centímetro), até o ponto $\mathrm{H}$; daí, deflete à esquerda e segue no azimute 165¹4'14" pelo alinhamento predial da Rua da Abolição, numa distância de $91,14 \mathrm{~m}$ (noventa e um metros e quatorze centímetros), até o ponto I; daí, deflete à direita e segue no azimute $257^{\circ} 41^{\prime} 19^{\prime \prime}$ pelo alinhamento predial da 
Rua da Abolição, numa distância de 1,04m (um metro e quatro centímetros), até o ponto J; daí, deflete à esquerda e segue no azimute $165^{\circ} 05^{\prime} 00^{\prime \prime}$ pelo alinhamento predial da Rua da Abolição, numa distância de 122,49m (cento e vinte e dois metros e quarenta e nove centímetros), até o ponto L; daí, deflete à direita e segue no azimute $170^{\circ} 34^{\prime} 20^{\prime \prime}$ pelo alinhamento predial da Rua da Abolição, numa distância de 15,63m (quinze metros e sessenta e três centímetros), até o ponto $\mathrm{M}$; daí, segue em curva à direita pelo alinhamento predial da Rua da Abolição, com desenvolvimento de 9,41m (nove metros e quarenta e um centímetros) até o ponto $\mathrm{N}$; daí, segue no azimute $214^{\circ} 08^{\prime} 54^{\prime \prime}$ pelo alinhamento predial da Rua da Abolição, numa distância de 122,97m (cento e vinte e dois metros e noventa e sete centímetros), até o ponto O; daí, deflete à direita e segue no azimute $226^{\circ} 00^{\prime} 12^{\prime \prime}$ na confluência dos alinhamentos prediais da Rua da Abolição e Rua Oratório, numa distância de $18,44 \mathrm{~m}$ (dezoito metros e quarenta e quatro centímetros), até o ponto P; daí, deflete à direita e segue no azimute $231^{\circ} 18^{\prime} 13^{\prime \prime}$ pelo alinhamento predial da Rua Oratório, numa distância de 4,70m (quatro metros e setenta centímetros), até o ponto Q; daí, deflete à direita e segue no azimute $294^{\circ} 26^{\prime} 33^{\prime \prime}$, numa distância de 191,38m (cento e noventa e um metros e trinta e oito centímetros), confrontando com os imóveis de Classificações Fiscais 04.004.013 e 04.004.014 respectivamente, até encontrar o ponto A, inicio desta descrição.

O perímetro acima descrito, encerra uma área de $76.951,86 \mathrm{~m}^{2}$ (setenta e seis mil e novecentos e cinqüenta e um metros e oitenta e seis decímetros quadrados)". 
ANEXO B

CARTA INTERMINISTERIAL 


\section{SUBCHEFIA DE ASSUNTOS PARLAMENTARES}

EM Interministerial n² 179/2004/MEC/MP

Brasilia, 07 de julho de 2004

Excelentíssimo Senhor Presidente da República,

1. Submetemos à apreciação de Vossa Excelência o anexo Projeto de Lei que institui a Fundação Universidade Federal do ABC - UFABC, entidade vinculada ao Ministério da Educação, que terá sede na cidade de Santo André, Estado de São Paulo.

2. A expansão da rede de ensino superior e a ampliação do investimento em ciência e tecnologia são objetivos centrais do governo federal e foco do de bate sobre a reforma universitária. A criação de uma grande universidade pública no coração da indústria, na maior região metropolitana do país, é uma clara demonstração de compromisso com o desenvolvimento, a cultura e a democratização do acesso ao ensino superior. É uma das iniciativas que renovam a confiança do país em si mesmo e têm o poder de mobilizar as novas gerações para a invenção do futuro.

3. $\triangle A B C$ paulista representou, desde os anos 1950, a vontade de superação do subdesenvolvimento, a industrialização, a energia do empreendimento e as expectativas de progresso e mobilidade social. Mais

- recentemente, tornou-se parte da história brasileira de afirmação das liberdades e da cidadania, expressão do moderno movimento operário e das lutas pela democracia. A reforma universitária começa como deve ser: com investimento público em educação e ciência, inovação institucional e confiança no Brasil.

4. Nasce uma nova universidade federal comprometida com o desenvolvimento e a democracia, aberta a todos os brasileiros, com características de uma Universidade tecnológica para a formação de profissionais de elevada qualificação em áreas estratégicas para o desenvolvimento brasileiro, produção de conhecimento e tecnologia para a indústria, gestão de empresas, políticas públicas e educaçẫo básica; de uma Universidade aberta que utilize tecnologias educacionais e permita o atendimento de um grande número de estudantes, além de ter uma organização curricular flexível que multiplique as oportunidades de formação, e, de uma universidade democrática, de gestão participativa com efetiva contribuição de trabalhadores, empresários e organizações não governamentais. 5. De suas características estratégicas decorrem algumas inovações e avanços institucionais, tais
como:

- laboratórios integrados às empresas;

- programas de formação, pesquisa e extensão decorrentes da parceria entre empresas e universidades;

- observatórios da sociedade e da economia com o propósito de gerar conhecimento sobretudo sobre as regiões do $A B C$;

- associação com a administração pública para a formação de pessoal em gestão e políticas públicas;

- associação com a educação básica para a formação inicial e continuada de profissionais e o desenvolvimento de tecnologias educacionais, projetando um novo padrão de integração entre a universidade e a educação básica; 
- graduação em regime semipresencial com redução da carga de trabalho em sala de aula presencial, apoio diferenciado ao estudante e valorização dos docentes,

- flexibilidade curricular: instituição de um ciclo básico, ampliação das oportunidades de formação profissional e de acesso à pós-graduação;

- Universidade com autonomia de gestão, financeira e patrimonial, gerida com a participação de seus profissionais, alunos e da sociedade civil.

6. A universidade deverá inicialmente ser integrada por três centros, que traduzem as características estratégicas: Centro de Tecnologias e Indústria, Centro de Educação e Centro de Ciências Sociais.Tendo como metas 20.000 estudantes em cursos de graduação semipresenciais, 2.500 estudantes em cursos de mestrado profissionais semipresenciais e 1.000 estudantes em cursos de doutorado, além de 600 professores doutores em tempo integral e 1.000 monitores bolsistas dos programas de pós-graduação.

7. A estrutura organizacional proposta, tanto administrativa como acadêmica, é extremamente simplificada, o que propiciará que a Universidade torne-se ágil, eficiente e de baixo custo operacional. Deverão ser criados os cargos necessários para compor o quadro de pessoal, quais sejam: um CD-1, um CD-2, dez CD-3, quatorze CD-4, trinta e oito FG-1, vinte e dois FG-2, quinze FG-3, dezenove FG-4, vinte e seis FG-5, além dos seiscentos docentes, cento e cinqüenta e seis técnico-administrativos de nível superior e trezentos técnico-administrativọ de nível intermediário.

8. A repercussão financeira anual quando da plena implantação da Universidade, referente a pessoal e custeio, está estimada na ordem de $R \$ 150.000 .000,00$ (cento e cinqüenta milhões de reais). No processo de implantação, as projeções indicam a necessidade de um aporte anual de recursos da ordem de R\$ $30.000 .000,00$ (trinta milhões de reais) para o primeiro ano.

9. Quanto ao disposto nos art. 16 e 17 da Lei Complementar no 101, de 04 de maio de 2001, pode ser considerado plenamente atendido, uma vez que o acréscimo de despesa no corrente exercício está contido nos valores da Lei Orçamentária de 2004. Para os exercícios de 2005 e 2006, as estimativas de custos reduzirão a margem líquida de expansão para despesas de caráter continuado daqueles exercícios. No entanto, esse aumento de despesa mostra-se compativel com o aumento de receita decorrente do crescimento real da economia previsto, conforme demonstra a série histórica relativa à ampliação da base de arrecadação nơs últimos anos.

10. Acreditamos, Senhor Presidente, que a criação da UniABC trará grandes benefícios para a maior região metropolitana do país. Ampliará a oferta de ensino superior à população e; ao mesmo tempo, gerará conhecimentos científicos e tecnológicos necessários ao desenvolvimento, à prosperidade e ao bem estar da população paulista e brasileira.

\section{Respeitosamente,}

\author{
GUIDO MANTEGA \\ Ministro de Estado do Planejamento, \\ Orçamento e Gestão
}

\author{
TARSO GENRO \\ Ministro de Estado da Educação
}


ANEXO C

DIRETRIZES CODESUR SANTO ANDRÉ 


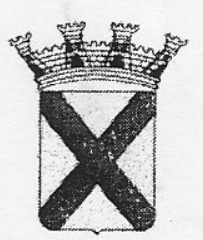

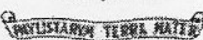

PREFEITURA MUNICIPAL. DE SANTO ANDRE

ESTADO DE SÁOPAULO - BRASIL

À

Rubrica cpsr

Secretaria de Desenvolvimento Urbano e Habitação

\section{Senhora Secretária,}

O CODESUR em reunião plenária realizada em 04 de outubro de 2005; Analisando o processo administrativo $n^{\circ} 37.424 / 2005-7$.

Interessado: Termo de Referência / Universidade Federal do ABC - UFABC.

\section{PARECER № 128 / 2005.}

Para os imóveis classificados na Prefeitura Municipal de Santo André sob os $n^{\circ}$ s $04.004 .016 /$. 004, zoṇa B, situados às Av. dos Estados / Ruas Santa Adélia / da Abolição / Oratório - Bangú; manifestou-se favorável à implantação da Universidade Federal do. ABC, desde que obedecidos os seguintes parâmetros urbanísticos, contidos às fls. 19/20, 23 / 24 e 26 do presente, ou seja:

\section{-1. Diretrizes do Serviço Municipal e Sạneamento Ambiental de Santo André - SEMASA:}

- Introdução

A área, onde será implantada a futura Universidade Federal do $A B C$ apresenta cerca de 70 mil $\mathrm{m}^{2}$ e está inserida na Avenida dos Estados, na várzea e planície de inundação do Rio Tamanduateí, e que de acordo com o Código Florestal (Lei 4.771 de 15/09/1965) parte da gleba encontra-se em Área de Preservação Permanente (APP).

Encontra-se sobre sedimentos quartenários formados por argilas, areias e cascalhos, intercalados, em relevo plano de planície aluvionar.

Atualmente a área vem sendo utilizada como garagem da Prefeitura Municipal de Santo André, abrigando várias unidades; tais como: posto de lavagem da frota municipal, borracharia, posto de abastecimento de combustível, oficina mecânica, diversos sanitários, restaurante, ambulatório, estacionamento de funcionários e bota fora da antiga frota (onde foram observados carcaças de ônibus, caminhão-pipa, dentre outros).

Ressalta-se que a cerca de três anos haviam cinco tanques subterrâneos armazenadores de combustíveis (álcool, gasolina e diesel). Estes tanques foram substituídos por unidades aéreas.

Encontra-se praticamente toda impermeabilizada por meio de edificações e revestimento de paralelepípedo. A cobertura vegetal é dada por alguns exemplares de espécies arbóreas de pequeno a grande porte e por espécies frutiferas.

A área do entorno encontra-se bastante antropizada, cuja vizinhança próxima é dada por edificações residenciais e pelo Carrefour. As principais vias de acesso são caracterizadas por fluxos intensos, principalmente nos horários de pico.

CONSELHO DE DESENVOLVIMENTO URBANO - SECRETARIA DE DESENVOLVIMENTO URBANO E HABITAÇÃO

Praça IV Centenário, n० 01 - Prédio do Executivo, Térreo II, Centro - Santo André

CEP: 09015-080 - Telefone: 4433.0437 - Fax 4433.0410 


\section{- Aspectos Ambientais a serem considerados:}

- Avaliação do passivo ambiental e de risco a saúde humana visto que a área vem sendo utilizada como oficina, garagem, posto de lavagem e abastecimento da frota municipal. Ressalta-se que até ha três anos atrás a área abrigava 5 tanques subterrâneos que armazenava álcool, gasolina e diesel. E a realização da remediação ambiental da área, caso necessária.

- Avaliação da cota de inundação e histórič de enchentes da área, visto que a universidade irá abrigar cerca de 20.000 alunos-de graduação, 2.500 de mestrado e 1.000 de doutorado, além de docentes e funcionários em geral.

- Para a elaboração do projeto da universidade considerar a faixa do terreno inclusa ná Área de Preservação Permanente do Rio Tamanduateí, que pode variar de 30 metros (largura do rio < 10 metros) a 50 metros (largura entre 10 e 50 metros).

- Avaliação do aumento de tráfego de veículos, visto que a universidade está inserida num importante corredor de ligação $A B C$ / Capital, Av. dos Estados; e avaliação da demanda de estacionamentos;

- Avaliação do aumento da população vizinha e especulação imobiliária na região;

- Avaliação da capacidade de suporte dos equipamentos urbanos e comunitários;

- Avaliação da demanda de transporte público;

- Diagnóstico das espécies arbóreas existentes na área, como forma de preservar os exemplares mais significativos, assim como, implementar medidas compensatórias com o plantio de espécies vegetais nativas da região;

- Decorrente do aumento do consumo de energia elétrica, recomenda-se como medida mitigadora analisar a possibilidade da adoção de energia solar, assim como projetos de iluminação apropriados;

- Decorrente do aumento do consumo de água, recomenda-se como medida mitigadora a implantação de dispositivos de captação de águas pluviais para serem utilizadas nos jardins, e outras unidades compatíveis com a qualidade da água, assim como a implantação de vc com caixa acoplada e torneiras com sensores;

- Decorrente do aumento da geração de resíduos sólidos, recomenda-se como medida mitigadora a implantação de coleta seletiva e de programas ambientais voltados a diminuição do desperdício de resíduos recicláveis, principalmente papel e embalagens em geral;

- Implantar estruturas apropriadas para portadores de necessidades especiais; 
Proc. $n^{\circ} 37.424 / 2005-7$

Folha $\mathrm{n}^{\circ} 31$
Rubrica $\mathrm{cps}$

Folha $n^{\circ} 31$
Rubrica cpsr

PREFEITURA MUNICIPAL DE SANTO ANDRE

ESTADO DE SAO PAULO - BRASIL

- Implementar Plano de Controle Ambiental das medidas mitigadoras e compensatórias propostas.

2. Diretrizes do Departamento de Trânsito e Circulação - DTC:

\section{Introdução}

Considerando- se os dados iniciais apresentados sobre a universidade, todas as diretrizes emitidas levam em consideração o cenário do quarto ano de funcionamento, onde se configura a ocupação máxima do cenário do primeiro ano.

Desta forma, considerando a infra-estrutura da rede de transporte atual a universidade poderá ser acessada por:

- Trem: devendo atender principalmente o público de São Paulo, São Caetano do Sul, Rio Grande da Serra, Ribeirão Pires e Mauá.

- Corredor EMTU São Mateús - Jabaquara: devendo atender principalmente o público de São Paulo (Zona Leste), São Bernardo do Campo, Diadema, Mauá e Santo André.

- Linhas Municipais: cinco linhas devendo atender principalmente o público de Santo André.

- Linha Intermunicipal: devendo atender principalmente o público de São Caetano do Sul e Santo André.

\section{Divisão Modal}

Sugerimos a adoção das seguintes divisões modais de transporte:

\begin{tabular}{|c|c|c|c|c|c|c|c|}
\hline & $\begin{array}{l}\text { Transporte } \\
\text { Universitário } \\
\text { (Vans) (\%) }\end{array}$ & $\begin{array}{c}\text { Ônibus } \\
\text { Fretado } \\
(\%)\end{array}$ & $\begin{array}{c}\text { Automóvel } \\
\text { (\%) }\end{array}$ & $\begin{array}{l}\text { Moto } \\
\text { (\%) }\end{array}$ & $\begin{array}{l}\text { A pé } \\
(\%)\end{array}$ & $\begin{array}{c}\text { Bicicleta } \\
(\%)\end{array}$ & $\begin{array}{c}\text { Ônibus } \\
\text { e trem } \\
(\%)\end{array}$ \\
\hline Alunos & 3,0 & 0,5 & 37,0 & 3,0 & 1,0 & 0,5 & 55,0 \\
\hline Docentes & - & - & 80,0 & - & - & - & 20,0 \\
\hline Funcionários & - & - & 30,0 & - & - & - & 70,0 \\
\hline Visitantes & - & - & 40,0 & - & - & - & 60,0 \\
\hline
\end{tabular}

Esta divisão modal deve ser utilizada:

- Para o cálculo de vagas de estacionamento, devendo todas as vagas ser internas ao lote.

- Dimensionamento das vias de circulação e acesso de veículos.

- Adequações do sistema viário e de transporte do entorno.

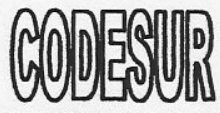

CONSELHO DE DESENVOLVIMENTO URBANO - SECRETARIA DE DESENVOLVIMENTO URBANO E HABITAÇÃO Praça IV Centenário, no 01 - Prédio do Executivo, Térreo II, Centro - Santo André CEP: 09015-080 - Telefone: 4433.0437 - Fax 4433.0410 


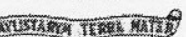

PREFEITURA MUNICIPAL DE SANTO ANDRE

ESTADO DE SÁOPAULO - BRASIL

Proc. $\mathrm{n}^{\circ} 37.424 / 2005-7$

Folha $n^{\circ} 32$

Rubrica cpsr

\section{Acessos}

A entrada de veículos deve ser única, por via marginal a ser projetada na Avenida dos Estados.

Devem ser projetadas duas saídas: uma pela marginal na Avenida dos Estados e outra pela Rua Abolição, no trecho entre a Rua Oratório e Rua Paulina Isabel de Queiroz.

Poderá ser admitido ùm acesso para veículos de serviços na Rua Santa Adélia.

Os acessos de pedestres devem ser locados em todas as interseções viárias e na proximidade dos pontos de transporte coletivo.

\section{Referências de Projèto}

Volume diário médio no dia útil direcional da Av. dos Estados: 40.000 veículos

Volume na hora-pico no dia útil direcional da Av. dos Estados: 3.000 veículos, sendo $89 \%$ veículos de pásseio e $11 \%$ veículos comerciais.

Prever conexão entre o Campus e as estaçọ̃es de trem Prefeito Saladino e Prefeito Celso Daniel e terminais de ônibus urbanos próximos a estas estações.

Prever infra-estrutura para parada de ônibus fretado e táxi.

Considerar para fins de adequação do sistema viário e de transporte a área de estudo anexa.

\section{Diretrizes do Departamento de Controle Urbano}

Como a zona B é prevista para os usos institucionais públicos e como não há parâmetros previamente fixados, sugerimos os seguintes índices e restrições urbanísticas para a implantação pretendida:

$\checkmark$ Coeficiente de aproveitamento máximo: 1,50

$\checkmark$ Coeficiente de ocupação máxima do lote: $75 \%$

$\checkmark$ Área permeável mínima: $20 \%$

$\checkmark$ Recuos mínimos: 10,00 metros para a Av. dos Estados / 5,0 metros para as demais vias circundantes.

$\checkmark$ Gabarito máximo: $\mathbf{G} \leq \mathbf{3}(r+1)$, sendo $r=$ recuo da edificação / / largura da via

$\checkmark$ Estacionamento: atender as diretrizes do Departamento de Trânsito e Circulação DTC. 
$\checkmark$ Observar a Resolução nº 001 / 2004 - CODESUR, de 04 de junho de 2004, quanto ao estacionamento, quando coberto.

1. Podendo ser aflorado na cota máxima de $1,50 \mathrm{~m}$ acima do nivel mais alto do alinhamento.

2. Não sendo computados nos índices urbanísticos.

3. Se aflorado, deverá observar o recuo frontal fixado.

Considerado ainda a especificidade do empreendimento e conforme tratativas das várias áreass- da PMSA envolvidas no projeto de implantação, sugerimos ainda que deva ser exigido:

$\checkmark$ Licenciamento Ambiental Municipal;

$\checkmark$ Sendo Área de Proteção Permanente - APPP: faixa de 50,00 metros de afastamento do corpo d'água;

$\checkmark$ Diretrizes do Departamento de Trânsito e Circulação;

$\checkmark$ Relatórios de impacto EIV / RIV;

$\checkmark$ Aprọvação no Corpo de Bombeiros;

$\checkmark$ Aprovação na Vigilância à Saúde;

$\checkmark$ Aprovação pelo Departamento de Vias Públicas - DVP;

$\checkmark$ Aprovação com base no Código de Obras e Edificações de Santo André - COESA (Lei 8.065/00).

4. Em havendo parcelamento deverá ser observada a legislação vigente (Federal, Estadual e Municipal).

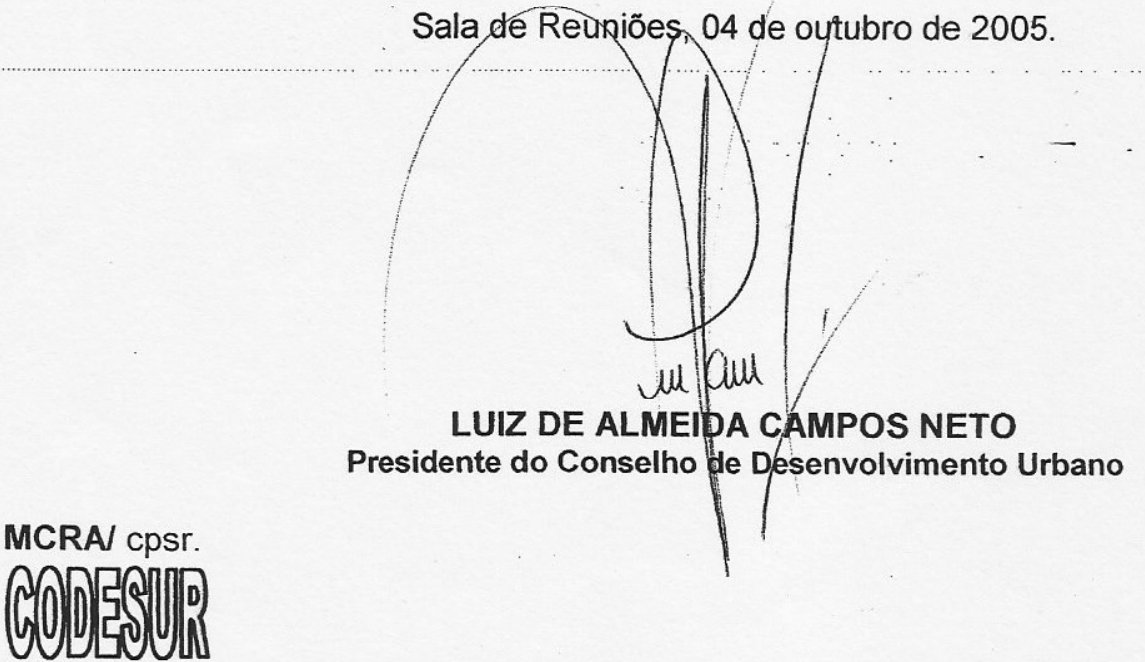

CONSELHO DE DESENVOLVIMENTO URBANO - SECRETARIA DE DESENVOLVIMENTO URBANO E HABITAÇÃO Praça IV Centenário, no 01 - Prédio do Executivo, Térreo II, Centro - Santo André CEP: 09015-080 - Telefone: 4433.0437 - Fax 4433.0410 
ANEXO D

MINUTA TERMO DE REFERÊNCIA

EDITAL PROJETOS SANTO ANDRÉ 


\section{Instituto de Arquitetos do Brasil}

Membro da União Internacional de Arquitetos - UIA

\section{LICITAÇÃO PÚBLICA NACIONAL NA MODALIDADE CONCURSO DE PROJETO PARA O CAMPUS DA UNIVERSIDADE DO ABC NA CIDADE DE SANTO ANDRÉ}

O Ministério da Educação, entidade PROMOTORA, e a Direção Nacional do Instituto de Arquitetos do Brasil IAB , entidade ORGANIZADORA, e Prefeitura de Santo André , entidade CONVENIADA, instituem Concurso Público Nacional de Projeto de Arquitetura para o Campus da Universidade Federal do ABC na cidade de Santo André. Esta licitação pública nacional, doravante chamada simplesmente de CONCURSO, está organizada conforme as normas da Lei 8666/93, constituindo-se em modalidade de licitação prevista no seu artigo 22 , sendo sua condições complementadas, onde pertinente, pelo REGULAMENTO DE CONCURSOS PARA PROJETOS DE ARQUITETURA do IAB e pelos itens a seguir.

\section{OBJETO do CONCURSO}

O presente Concurso tem por objeto a seleção em etapa única, dentre as propostas apresentadas, da solução de anteprojeto arquitetônico mais adequada para realização de projeto básico e executivo para o Campus da Universidade Federal do $A B C$ a ser construído à Avenida dos Estados, esquina com Rua Santa Adélia, Bairro Bangu, Município de Santo André, SP, em terreno de cerca de 77.000,00 m2 e com uma previsão de construção em uma primeira etapa de aproximadamente $40.000,00 \mathrm{~m} 2$, e custo estimado de $\mathrm{R} \$ 50.000 .000,00$ (cinqüenta milhões de reais) com total liberdade de proposição, uma vez obedecidas as indicações e determinações do conjunto de documentos intitulado BASES DO CONCURSO, composto por:

- Este Edital, contendo as regras gerais do concurso, prazos e condições mínimas de participação

- Regulamento do concurso, onde são detalhadas as condições e instruções de participação, tais como formatos de desenhos e outras condições pertinentes ao bom entendimento das propostas e homogeneização de dados, bem como as condições para a avaliação das propostas e demais diretrizes ao trabalho do júri.

- Termo de Referência, onde são expostas as diretrizes a serem obedecidas na concepção do projeto, compreendendo:

- Programa de necessidades do conjunto a edificar, áreas aproximadas $\left(\mathrm{m}^{2}\right)$.

- Localização e dimensões do terreno, legislação de uso do solo, gabarito.

Levantamento topográfico digitalizado.

Levantamento fotográfico do local digitalizado.

Sondagens geotécnicas

Informações gerais (clima, estimativa de tráfego, ligação com a cidade).

Diretrizes específicas a estabelecidas pela PROMOTORA, tais como possíveis etapas de execução de obra e outras que possam impactar o desenvolvimento das propostas.

- Minuta do Contrato a ser estabelecido entre a equipe vencedora do Concurso e a PROMOTORA, com escopo dos serviços, valores e prazos definidos em cronograma, incluindo-se os projetos complementares previstos para cada fase de projeto no Manual de Obras Públicas - Projeto - Práticas SEAP.

\section{DOS REQUISITOS À PARTICIPAÇÃO}

2.1 O presente Concurso está aberto à participação de todos os profissionais diplomados em nível superior, legalmente habilitados no Brasil para o exercício das atribuições exigidas para a execução dos serviços constantes de seu objeto e em situação regular perante o respectivo Conselho Regional de Engenharia, Arquitetura e Agronomia - CREA.

2.2 Um mesmo profissional somente poderá concorrer com uma única inscrição e um único trabalho, sendo vedada a participação de qualquer profissional em mais de um trabalho, seja como co-autor, membro de equipe, colaborador, consultor, ou em qualquer outra condição.

2.2 Estão impedidos de participar deste Concurso:

a) dirigentes e funcionários integrantes dos quadros da entidade promotora; 
b) membros da Direção Nacional do Instituto de Arquitetos do Brasil, da Coordenação do Concurso, da Comissão Julgadora, Consultores e colaboradores contratados para prestarem serviços ao Evento;

c) sócios formais e/ou parentes em $1^{\circ}$ grau dos profissionais supracitados.

\section{DAS INSCRIÇÕES E DA DOCUMENTAÇÃO}

3.1. As inscrições para o presente Concurso serão recebidas no período de 11/11/2005 a 14/12/2005 e as Fichas de Inscrição estarão disponíveis na internet (http://www.iab.org.br/concursouufabc/inscricoes ).

3.2. Uma vez haja sido a Ficha de Inscrição devidamente preenchida ela deverá ser enviada via internet, conforme instruções no endereço eletrônico acima, mas a homologação da inscrição se dará pelo recebimento da documentação abaixo relacionada, via correio ou pelo fax (21) 2533-9514.

- Cópia do Cartão de Identidade Profissional do CREA;

- Comprovante de quitação da anuidade de 2003 do CREA;

- Comprovante de quitação da anuidade de 2003 do IAB, para os associados;

- Comprovante de pagamento da taxa de inscrição.

3.3. O valor da taxa de inscrição é de $R \$ 100,00$ (cem reais), para os associado do IAB que comprovarem quitação da anuidade de 2003 e de $R \$ 200,00$ (duzentos reais) para os demais profissionais, devendo ser paga em favor de:

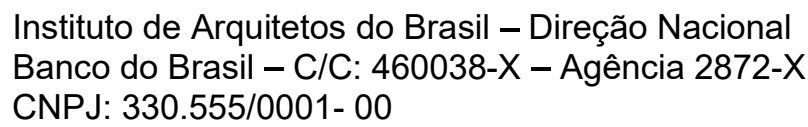

34. As inscrições serão sempre individuais, devendo ser feitas pelos próprios concorrentes - ou seus procuradores formalmente constituídos - os quais serão considerados os "profissionais responsáveis", facultando-se a indicação, na Ficha de Inscrição, de Pessoa Jurídica da qual o inscrito seja sócio majoritário, para fins de recebimento de prêmio ou contratação do desenvolvimento do projeto, observadas as disposições constantes das Bases do Concurso.

3.5. As inscrições também poderão ser realizadas diretamente, na sede do IAB, no seguinte endereço:

Instituto de Arquitetos do Brasil - Direção Nacional,

Avenida Rio Branco, $\mathrm{n}^{\circ} .277$ sala 1301 ,

Cep.: 20040-009 - Centro/ Rio de Janeiro, RJ.

3.6. Uma vez recebidas a Ficha de Inscrição e a documentação solicitada (vide 3.2) e, estando tudo em conformidade com as exigências deste Edital, as inscrições serão homologadas e os inscritos serão devidamente comunicados e deverão receber, diretamente ou através dos Correios, 01 (um) exemplar das BASES DO CONCURSO, em formato digital.

\section{DAS CONSULTAS}

4.1. Os inscritos poderão dirigir pedidos de esclarecimentos ou consultas relativos às Bases do Concurso, no período compreendido entre 12/11/2005 e 19/12/2005.

4.2. Os pedidos de esclarecimentos ou consultas deverão ser feitos através da internet (http://www.iab.org.br/concursoufabc/consultas) ou via fax (21) 2533-9514.

4.3. Serão respondidas pelo Coordenador do Concurso, todas as consultas e pedidos de esclarecimentos formulados, observadas as disposições do Regulamento do Concurso relativas à manutenção do sigilo quanto aos nomes dos consulentes e ao calendário de distribuição dos lotes de respostas. Todas as consultas e informações relevantes ao desenvolvimento das propostas serão publicadas na página eletrônica específica, de livre acesso, sendo também encaminhadas diretamente aos participantes por meio eletrônico. 


\section{DO ENCAMINHAMENTO E DO RECEBIMENTO DOS TRABALHOS}

5.1 Os trabalhos deverão ser encaminhados à Sede do IAB, aos cuidados do Arquiteto Coordenador do Concurso, no endereço indicado em 3.5 até às 18:00 horas do dia 06/01/2006. No caso daqueles enviados via postal, ou através de empresas transportadoras, serão recebidos apenas aqueles postados comprovadamente até às 24:00 horas do mesmo dia 06/01/2006. O período de tolerância para recebimento dos trabalhos enviados via postal, ou através de empresas transportadoras encerra-se às 10:00 horas do dia 09/05/04. Os trabalhos que forem enviados por via postal devem ser imediatamente comunicados à Secretaria do Concurso pelo fax (21) 2533-9514, ou por mensagem eletrônica para secretaria@iab.org.br informando o "número de conhecimento", para facilitar o acompanhamento do trabalho.

5,2 A apresentação das propostas será em nível de Anteprojeto Arquitetônico, com informação relativa à implantação da obra, aos acessos, ao esquema geral das circulações, ao espaço funcional utilizável, ao conjunto estrutural, ao sistema construtivo, aos esquemas básicos das instalações prediais e especiais, ao conforto ambiental (térmico, acústico e lumínico), à viabilidade do empreendimento (estimativa de custo), à discriminação geral de materiais e técnicas construtivas, incluindo-se um memorial justificativo resumido.

5.3 A formatação das propostas está detalhada no Regulamento do Concurso.

5.4 Em nenhuma hipótese e sob nenhum pretexto serão aceitos trabalhos que forem entregues em desacordo com a forma e prazos previstos neste Edital e demais documentos das BASES DO CONCURSO.

\section{DA COMISSÃO JULGADORA E DO JULGAMENTO}

6.1. A Comissão Julgadora será composta por sete membros titulares e dois suplentes, de acordo com o Regimento de Concursos do IAB:

- Jurado A ( indicado pelo IAB de seu Corpo de Jurados) .

- Jurado B ( indicado pelo IAB de seu Corpo de Jurados)

- Jurado C ( indicado pelo IAB de seu Corpo de Jurados )

- Jurado D (indicado pelo IAB de seu Corpo de Jurados)

- Jurado E ( indicado pelo MEC).

- Jurado F ( indicado pelo MEC).

- Jurado E ( indicado pela Prefeitura de Santo André)

- Dois suplentes indicados pelo IAB de seu Corpo de Jurados

6.2 A Comissão Julgadora contará com o apoio da Coordenação do Concurso e de consultoria Jurídica caso necessário, na forma descrita pelo Regulamento do Concurso.

6.3 O julgamento se fará em uma única fase, e as reuniões da Comissão Julgadora serão sigilosas, sendo necessária a presença de um quorum de, no mínimo, 05 (cinco) de seus membros para sua realização.

6.4 Os trabalhos serão analisados pela Comissão Julgadora, nos termos estabelecidos no Regulamento do Concurso, que emitirá o resultado final do Concurso, ordenando-os em $1^{\circ}, 2^{\circ}$ e $3^{\circ}$ Colocados, sendo vedado qualquer possível empate entre os trabalhos concorrentes. A CRITÉRIO DA Comissão julgadora poderão ser emitidas Menções Honrosas.

6.4 As decisões de mérito da Comissão Julgadora são irrecorríveis. São admitidos apenas recursos de caráter administrativos, no período do item 9.6.

6.5 O resultado do julgamento dos trabalhos será conhecido em sessão pública solene no dia 13 de janeiro de 2005, em hora e local a serem definidos pela Entidade Promotora. 


\section{Instituto de Arquitetos do Brasil}

Membro da União Internacional de Arquitetos - UIA

\section{PremiaçÃo:}

7.1 Após a divulgação do resultado final do Concurso e da classificação final serão conferidos a seus respectivos autores os seguintes Prêmios:

$1^{\circ}$ Colocado: $\mathrm{R} \$ 30.000,00$ (trinta mil reais);

$2^{\circ}$ Colocado: $\mathrm{R} \$ 20.000,00$ (vinte mil reais) e

$3^{\circ}$ Colocado: $\mathrm{R} \$ 10.000,00$ (dez mil reais)

7.2 No mesmo ato, será assinado um termo de compromisso entre a PROMOTORA e o primeiro classificado no Concurso, objetivando a contratação para o desenvolvimento do Projeto, na forma definida pela minuta de contrato incluída nas BASES DO CONCURSO, respeitadas a documentação e demais condições exigidas pela legislação.

7.3 Caso o vencedor do concurso não apresente a documentação e condições legais exigidas no prazo de 30 dias, a PROMOTORA poderá convocar para contrato o segundo colocado e, se este também inadimplir 30 dias após esta convocação, o terceiro colocado.

7.3 Será ser atribuída ao contratado a responsabilidade pelo desenvolvimento de seu projeto e dos projetos complementares de cálculo estrutural, instalações prediais e especiais, conforto ambiental, paisagismo, programação visual e outros estudos ou projetos necessários para a realização da obra, conforme disposto na minuta de contrato.

\section{EXPOSIÇÃo E RETIRADA dOS TRABALHOS CONCORRENTES :}

8.1 Após a premiação e findo o prazo de recurso, serão expostos, para conhecimento público, por um período mínimo de duas semanas: a Ata do Concurso, todos os projetos concorrentes devidamente identificados com destaque para o trabalho vencedor, assim como para os demais classificados e para os que eventualmente receberem menções honrosas.

8,2 Os trabalhos selecionados serão também encaminhados às revistas técnicas especializadas para possível publicação.

8.3 A participação neste concurso implica na autorização dos autores para estas exposições e publicações, sem ônus para nenhuma parte.

8.4 Os trabalhos deverão ser retirados na sede do IAB Nacional em até 30 dias após a notificação de sua liberação. Caso não sejam retirados neste prazo, caberá ao IAB decidir sobre seu destino.

\section{CRONOGRAMA}

9.1 Inscrições: de 11 de novembro até 14 de dezembro de 2006;

9.2 Consultas: de 14 de novembro até 19 de dezembro de 2005;

9.3 Entrega dos trabalhos: até 18:00 do dia 06 de janeiro de 2006

9.4 Julgamento: de 10 a 13 de janeiro de 2006;

9.5 Divulgação do resultado do Concurso: 13 de janeiro de 2006

9.6 Prazo para recursos: de 13 a 21 de janeiro de 2006

9.7 Homologação do resultado: 21 de janeiro de 2006 


\section{CONCURSO PÚBLICO NACIONAL PARA A UNIVERSIDADE FEDERAL DO ABC}

\section{TERMO DE REFERÊNCIA}

\section{I - APRESENTAÇÃO}

O Ministério da Educação, o Instituto dos Arquitetos do Brasil e a Prefeitura de Santo André promovem o Concurso Publico Nacional de Anteprojetos de Arquitetura e Urbanismo para a Universidade Federal do ABC. Este concurso é regido pela Lei 8.666 de 23 de junho de 1.993 e demais legislações pertinentes.

O presente concurso tem por objeto a seleção da solução arquitetônica mais adequada para a implantação da Universidade, com total liberdade de proposição desde que atendidas às orientações e determinações deste Termo de Referência, do Edital do Concurso e eventuais Anexos.

\section{II - DO TERRENO}

A área de intervenção localiza-se na Avenida dos Estados, esquina com a Rua Santa Adélia e Rua da Abolição, Bairro Bangu, Santo André, Estado de São Paulo. O terreno possui 77.443,90 m2 (conforme cadastro fiscal) e 76.951,86 m2 (conforme levantamento planimétrico) e está localizada na várzea do Rio Tamanduateí e, sendo assim, parte da gleba é uma Área de Proteção Permanente, em faixa de 50m ao longo do rio, conforme o Código Florestal - Lei No. 4.771 de 15 de setembro de 1965. Está inserida na Macrozona de Reestruturação Urbana do município, conforme o Plano Diretor, Lei no. 8.696 de 17 de setembro de 2004. (ver lei do Plano Diretor Participativo em www.santoandre.sp.gov.br.)

\section{a) BREVE HISTORICO}

Os primeiros registros de ocupação do terreno datam de 1909. Em 1914 foi inaugurado o Matadouro Municipal (ou Modelo), uma concessão de vinte anos que a 
municipalidade deu à empresa Di Giulio Martinelli \& Cia. Durante o período concessionário os pavilhões do Matadouro funcionaram dentro das rigorosas normas sanitárias da época e o terreno passou por uma certa valorização imobiliária. Ao término da concessão há o registro que a Companhia Rhodia Chimica Brasileira fez uma oferta de compra do terreno à Municipalidade, mas uma Comissão da Câmara Municipal rejeitou a proposta alegando que o valor ofertado não estava à altura do imóvel. Alguns dos pavilhões do Matadouro construídos no inicio do século XX ainda resistem no local, conservando ainda suas características originais em condições precárias.

É recente o reconhecimento por parte do poder público do valor histórico do conjunto. $\mathrm{Na}$ implantação da Universidade poderá discutir-se sobre a pertinência da preservação desse espaço, sua requalificação e a possibilidade de sua inserção no bairro, contribuindo com a discussão sobre o patrimônio histórico da cidade.

\section{b) INSERÇÃO URBANA}

O terreno que, atualmente, é ocupado pelo Departamento de Manutenção e Obras e a Garagem Municipal, foi doado ao MEC pelo município para a implantação da Universidade Federal também como uma ação estratégica para promover o desenvolvimento da região. A área também faz parte de um importante perímetro que envolve a Avenida dos Estados, a ferrovia (antiga estrada de Ferro Santos Jundiaí) e o rio Tamanduateí cortando a cidade na sua porção Leste-Oeste, em um trecho de 8,5 km de extensão e superfície de 12 km².

Esse perímetro demarcado pelo "Projeto Eixo Tamanduatehy" foi criado em 1998 pela administração municipal para responder à reestruturação econômica que Santo André passou a partir dos anos 80 , gerando grandes vazios urbanos. 0 Projeto Eixo Tamanduatehy tem como objetivo:

- Reurbanizar uma faixa do território do município, entre a Avenida dos Estados, a Ferrovia e Avenida Industrial, produzindo um novo centro regional que atenda parte do Grande $A B C$ e das Zonas Leste e Sudeste da Capital, visando a policentralidade metropolitana, regional e municipal;

- Criar um diferencial de acessibilidade, por meio da transformação do transporte 
ferroviário de passageiros em trem metropolitano moderno, integrado ao futuro ramal $A B C$ do metrô, e da ligação da Avenida dos Estados ao Rodoanel, bem como pelo aperfeiçoamento da circulação relacionada à malha viária do município e da região;

- Integrar os territórios da cidade que hoje se encontram cortados pela estrada de ferro, por grandes terrenos e pelo Rio Tamanduateí, por meio de transposições de vários tipos (viadutos, passarelas, túneis e áreas verdes em continuidade paisagística), produzindo assim continuidade e coesão urbana, inclusive com o reaproveitamento planejado das áreas antes vinculadas à ferrovia.

- Conciliar no mesmo território a presença de comércio, serviços, habitação e indústria; de empreendimentos grandes, médios e pequenos dos diversos níveis de renda, com inclusão social, bem como integrar os referenciais novos e os tradicionais, tendo o espaço público de qualidade como elemento articulador;

- Criar contexto favorável à atividade econômica e à qualidade de vida, com adequada infra-estrutura de comunicações, energia elétrica, coleta e destinação de resíduos e drenagem, bem como de áreas verdes e corpos d'água despoluídos;

- Potencializar os investimentos públicos dos diversos níveis de governo, integrando as respectivas políticas setoriais, assim como os investimentos privados, estes por meio de parcerias que produzam um ambiente urbano qualificador tanto da cidade como dos empreendimentos;

- Desenvolver os projetos iniciados na Avenida Industrial e Avenida dos Estados, incluindo redesenho do sistema viário e novo paisagismo, para que atuem como desencadeadores da transformação de toda a área abrangida pelo Projeto.

Para maiores informações sobre o Projeto Eixo Tamanduatehy, consulte o endereço eletrônico www.santoandre.sp.gov.br.

NOTA: Para obtenção de dados relevantes para o projeto, relacionados com o desenvolvimento econômico, social e urbano do município podem ser obtidos também no endereço eletrônico www.santoandre.sp.gov.br. 


\section{III - DO OBJETO DO CONCURSO}

A UNIVERSIDADE FEDERAL DO ABC é uma das primeiras universidades federais do Brasil a ser inaugurada no século XXI. Desta forma, nasce com forte potencial para a inovação e diversificação, propondo uma estrutura que conjugue flexibilidade acadêmica e curricular com altos padrões de qualidade.

A UFABC será construída em vários locais, nos municípios do Grande $A B C$, seguindo o conceito de multicampi, conforme prevê a Lei que a criou. No futuro, deverá atender, no máximo, 20 mil alunos. O campus de Santo André comportará, no máximo, 9.000 alunos e 600 docentes. Para efeito de projeto considerar períodos com $40 \%$ de alunos de manhã, $40 \%$ de alunos a tarde e $20 \%$ a noite.

Deverão ser observados os seguintes aspectos conceituais:

\section{a) QUANTO AO CONTEXTO URBANO:}

- O adequado parcelamento do lote e do novo sistema viário, inserido ao tecido urbano pré-existente, considerando as complexidades urbanas como a ferrovia, o rio Tamanduateí e a Avenida dos Estados;

- A implantação do conjunto das edificações e sua relação com o entorno, objetivando compatibilizar o impacto gerado pela Universidade dentro do bairro;

- Atendimento do conceito de acessibilidade, que se refere ao cidadão na condição de pedestre, independente de seu modo veicular de locomoção e preferencialmente à sua condição física. Considerar todas as possibilidades de mobiliário urbano para enfrentar a questão;

- Consideração de que o terreno localiza-se na várzea do Rio Tamanduatehy e é uma Área de Proteção Permanente, dar soluções mitigadoras e compensatórias, atendendo às questões ambientais.

- O terreno está inserido no perímetro do Projeto eixo Tamanduatehy, da Prefeitura de Santo André, que se empenha em promover a reconversão urbana, econômica e social por meio do incentivo a novos empreendimentos em vazios urbanos subutilizados ou plantas industriais desativadas.

\section{b) QUANTO AO PROJETO DOS EDIFICIOS:}


- Previsão de soluções que considerem impreterivelmente o conforto dos usuários;

- Criação de espaços que propiciem o encontro de grandes e pequenos grupos, favorecendo a multiplicidade de contatos e confrontações de idéias;

- Proposição de tecnologias construtivas que obtenham o máximo de desempenho e a melhor relação custo-benefício, observando também o baixo custo de manutenção das edificações ao longo do tempo;

- Implantação mais adequada com respeito à topografia do terreno, a insolação e demais determinantes físicas para a implantação das edificações;

- Definição de uma linguagem estética que preserve o valor histórico do conjunto existente;

- Racionalização do consumo de água e energia.

\section{IV - DAS DIRETRIZES}

\section{URBANÍSTICAS E EDILÍCIAS}

Embora o Plano Diretor de Santo André tenha sido aprovado em dezembro de 2004, no período de projeto e implantação da Universidade Federal do $A B C$ continuará obedecendo a legislação de uso e ocupação do solo existente, definido para atender a fase de transição do novo Plano até a sua implantação definitiva. Assim, as propostas de anteprojetos deverão atender a seguinte legislação, cujos principais ínidices edilícios e urbanísticos estão descritos a seguir:

a) ZONEAMENTO Lei 5.042/76

b) PARCELAMENTO Lei $2.756 / 67$

c) POLO GERADOR DE TRAFEGO Lei $6.597 / 89$

d) CÓDIGO DE OBRAS MUNICIPAL lei 8.065/2000

e) LEI DE PARCELAMENTO 6.766/79 (caso ocorra a opção pelo parcelamento do solo).

F) ÍNDICES E RESTRIÇÕES:

- Zona B - Institucional Pública

- Coeficiente aproveitamento: 1,50 
- ZONA B - INSTITUCIONAL PÚBLICA

- Taxa ocupação: $75 \%$

- Área permeável: $20 \%$

- Recuos: Avenida dos Estados $10 \mathrm{~m}$ e $5 \mathrm{~m}$ para as demais vias

- Gabarito: $G<=3(r+L)$, onde $G=$ gabarito; $r=$ recuo; $L=$ largura da via.

- Área de Preservação Permanente (Avenida dos Estados) $=50$ metros

- Pólo Gerador de Tráfego: durante a tramitação para aprovação do Projeto Legal (planta de prefeitura) deverão ser atendidas as diretrizes do DTC Departamento de Transporte e Circulação.

- Licenciamento Ambiental: a UFABC deverá passar por processo de licenciamento ambiental na ocasião do desenvolvimento do projeto legal (Prefeitura).

- Empreendimento de Impacto: deverá ser realizado o Estudo de Impacto de Vizinhança; para o empreendimento;

- Aprovação pelo Corpo de Bombeiros

- Aprovação pela Vigilância à Saúde

- g) VAGAS DE ESTACIONAMENTO:

1. Estacionamento poderá estar localizado no máximo na cota $1,50 \mathrm{~m}$ acima do nível mais alto do alinhamento;

2. A área construída para o estacionamento, mesmo coberta, não será computada para efeitos do coeficiente de aproveitamento;

3. Se estiver implantado acima da cota $1,50 \mathrm{~m}$, deverá observar os recuos frontais.

4. Indicar acesso e mencionar no projeto a área para estacionamento de veículos para coleta de lixo e carga e descarga de mercadorias.

h) OUTRAS RECOMENDAÇÔES:

- Previsão de acesso para o pedestre, da Estação Ferroviária de Santo André/Terminal de ônibus e o campus,

- Passeios no entorno do campus de 4 metros e previsão de pontos de ônibus com abrigo 


\section{AMBIENTAIS}

A área encontra-se sobre sedimentos quaternários formados por argilas, areias e cascalhos intercalados, em relevo plano de planície aluvionar.

Atualmente a área vem sendo utilizada como garagem da Prefeitura Municipal de Santo André, abrigando várias unidades, tais como: posto de lavagem da frota municipal, borracharia, posto de abastecimento de combustível, oficina mecânica, diversos sanitários, restaurante, ambulatório, estacionamento de funcionários, e bota-fora da antiga frota.

Esses serviços estão em processo de desativação para a instalação da UFABC.

Havia na área cinco tanques subterrâneos armazenadores de combustíveis (álcool, gasolina e diesel) que foram substituídos por unidades aéreas.

Encontra-se praticamente toda impermeabilizada por meio de edificações e revestimento de paralelepípedo. A cobertura vegetal é dada por alguns exemplares de espécies arbóreas, de pequeno a grande porte, e por espécies frutíferas.

A área de entorno encontra-se bastante antropizada, cuja vizinhança próxima é dada por edificações residenciais e pelo Hipermercado Carrefour e outros estabelecimentos comerciais. As principais vias de acesso são caracterizadas por fluxos intensos, principalmente nos horários de pico.

Assim, serão considerados os seguintes aspectos:

- Faixa de $50 \mathrm{~m}$ de compensação ambiental ao longo do Rio Tamanduateí, a partir da crista do talude das margens do rio;

- Diagnóstico das espécies arbóreas existentes na área, como forma de preservar os exemplares mais significativos, assim como, implementar medidas compensatórias com o plantio de espécies vegetais nativas da região;

- Decorrente do aumento do consumo de energia elétrica recomenda-se como medida mitigadora analisar a possibilidade da adoção de energia solar; assim como, projetos de iluminação apropriados;

- Decorrente do aumento do consumo de água recomenda-se como medida mitigadora a implantação de dispositivos de captação de águas pluviais para 
serem utilizadas nos jardins, e outras unidades compatíveis com a qualidade da água, assim como a implantação de torneiras com sensores;

- Decorrente do aumento da geração de resíduos sólidos recomenda-se como medida mitigadora a implantação de coleta seletiva e de programas ambientais voltados à diminuição do desperdício de resíduos recicláveis, principalmente papel e embalagens em geral;

- Implantar estruturas apropriadas para portadores de necessidades especiais.

NOTA: Todas as medidas relacionadas às Diretrizes Ambientais e que não são representáveis graficamente no Concurso de Anteprojetos, deverá ser verificado quando do processo de licenciamento ambiental, e estar contempladas nas propostas formuladas.

\section{MOBILIDADE}

Para o dimensionamento das intervenções viárias e demais condições referentes à Mobilidade, necessárias à implantação da UFABC, elencamos algumas considerações.

A infra-estrutura da rede de transporte atual a universidade poderá ser acessada por:

a) Trem: devendo atender principalmente o público de São Paulo, São Caetano, Rio Grande da Serra, Ribeirão Pires, e Mauá.

b) Ônibus / Trolebus: Corredor EMTU São Mateus-Jabaquara: devendo atender principalmente o público de São Paulo (Zona Leste), São Bernardo do Campo, Diadema, Mauá, e Santo André.

c) Ônibus (linhas municipais): cinco linhas devendo atender principalmente o público de Santo André.

d) Ônibus (linha intermunicipal): devendo atender principalmente o público de São Caetano e Santo André.

\section{e) Divisão Modal}

Sugerimos a adoção das seguintes divisões modais de transporte: 


\begin{tabular}{|l|c|c|c|c|c|c|c|c|}
\hline & QT & $\begin{array}{c}\text { Transporte } \\
\text { Universitário } \\
(\text { Vans) }(\%)\end{array}$ & $\begin{array}{c}\text { Ônibus } \\
\text { Fretado } \\
(\%)\end{array}$ & $\begin{array}{c}\text { Automóvel } \\
(\%)\end{array}$ & $\begin{array}{c}\text { Moto } \\
(\%)\end{array}$ & $\begin{array}{c}\text { A pé } \\
(\%)\end{array}$ & $\begin{array}{c}\text { Bicicleta } \\
(\%)\end{array}$ & $\begin{array}{c}\text { Ônibus e } \\
\text { trem } \\
(\%)\end{array}$ \\
\hline Alunos & 9000 & 3,0 & 0,5 & 37,0 & 3,0 & 1,0 & 0,5 & 55,0 \\
\hline Docentes & 600 & - & - & 80,0 & - & - & - & 20,0 \\
\hline Funcionários & 200 & - & - & 30,0 & - & - & - & 70,0 \\
\hline Visitantes & 75 & - & - & 40,0 & - & - & - & 60,0 \\
\hline
\end{tabular}

Esta divisão modal deve ser utilizada:

- Para o cálculo de vagas de estacionamento, com vagas serem internas ao lote.

- Dimensionamento das vias de circulação e acesso de veículos.

- Adequações do sistema viário e de transporte do entorno.

\section{f. Acessos}

A entrada de veículos deve ser única, por via marginal a ser projetada na Avenida dos Estados. Devem ser projetadas duas saídas: uma pela via marginal na Avenida dos Estados e outra pela Rua Abolição, no trecho entre Rua Oratório e Rua Paulina Isabel de Queiroz.Poderá ser admitido um acesso para veículos de serviços na Rua Santa Adélia. Os acessos de pedestres devem ser locados em todas as interseções viárias e na proximidade dos pontos de transporte coletivo.

\section{g. Referências de Projeto}

Volume diário médio no dia útil direcional da Av. dos Estados: 40.000 veículos.

Volume na hora-pico no dia útil direcional da Av. dos Estados: 3.000 veículos, sendo $89 \%$ veículos de passeio e $11 \%$ veículos comerciais. Prever conexão entre o Campus e as estações de trem Prefeito Saladino e Prefeito Celso Daniel e terminais de ônibus urbanos próximos a estas estações. Prever infra-estrutura para parada de ônibus fretado e táxi.

Considerar para fins de adequação do sistema viário e de transporte, o mapa do terreno e arredores, disponibilizado em anexo. 


\section{PATRIMONIO HISTÓRICO}

Estudar as instalações do antigo matadouro municipal, constituído pelo conjunto de dois edifícios (prédio principal e prédio secundário), muro de arrimo e caixa d'água, (conforme localização em planta anexa) para, facultativamente, apresentar propostas de preservação e requalificação, considerando:

- Manutenção das características espaciais e da técnica construtiva existente;

- Integração espacial e funcional das edificações propostas com o conjunto a preservar;

- Adequação das edificações eventualmente a preservar ao novo uso, preferencialmente como espaço de convivência;

- Garantir visualização do conjunto, integrando-o à paisagem urbana.

\section{V - DO PROGRAMA DE NECESSIDADES}

\section{1. ÁREAS PARA CORPO ADMINISTRATIVO $=940,00 \mathrm{~m} 2$}

- Reitoria: Pesquisa, Administração, Pós Graduação, Extensão e Graduação

- Pró-Reitoria

- Prefeitura do Campus

- Núcleo de Assistência ao Estudante

\section{2. ÁREAS PARA CORPO DOCENTE $=6.800,00 \mathrm{~m}^{2}$}

- Centro de Ciências Naturais e Humanas $=1.700,00 \mathrm{~m}^{2}$

- Centro de Matemática, Computação e Cognição $=1.700,00 \mathrm{~m}^{2}$

- Centro de Engenharias, Modelagem e Ciências Sociais Aplicadas $=3.400,00 \mathrm{~m}^{2}$ 


\section{3. ÁREAS PARA ATIVIDADES DE ENSINO, PESQUISA E EXTENSÃO}

\subsection{Centro de Ciências Naturais e Humanas}

Física, Biologia, Físico-Química $=7.930,00 \mathrm{~m}^{2}$

Laboratórios de Ensino $=2.000,00 \mathrm{~m}^{2}$

2 laboratórios de Física (100 alunos/labor)

3 laboratórios de Química (100 alunos/labor)

Laboratórios de Pesquisa $=4.600,00 \mathrm{~m}^{2}$

Salas individuais para 50 docentes

Espaço comum para alunos de pós graduação

Salas para microscópios, espectrômetros, etc.

Oficinas $=250,00 \mathrm{~m}^{2}$

Oficina de serviços e manutenção

Salas de Aula $=1.080,00 \mathrm{~m}^{2}$

3 anfiteatros para 110 alunos com 1 computador para cada 2 alunos

3 anfiteatros para 130 alunos com mesa de demonstração

3 salas de aula para 60 alunos

\subsection{Centro de Engenharia, Modelagem e Ciências Sociais Aplicadas $=$}

\section{$9.730 \mathrm{~m}^{2}$}

Laboratório de Ensino $=1.800,00 \mathrm{~m}^{2}$

Salas para laboratórios de ensino e ensaios

Laboratório de Pesquisa $=4.800,00 \mathrm{~m}^{2}$

Salas individuais para 50 docentes

Espaço comum para alunos de pós-graduação

Previsão mínima de sala de $200 \mathrm{~m}^{2}$ com pé direito $9 \mathrm{~m}$

Salas para microscópios, espectrômetros,etc.

Oficinas $=250,00 \mathrm{~m}^{2}$

Oficina de serviços e manutenção

Salas de Aula $=2.880,00 \mathrm{~m}^{2}$

6 anfiteatros para 110 alunos com 1 computador para cada 2 alunos

6 anfiteatros para 130 alunos com mesa de demonstração 
6 salas de aula para 60 alunos

\subsection{Centro de Matemática, Cognição e Computação $=4.730 \mathrm{~m}^{2}$}

Laboratórios e Usuários $=600,00 \mathrm{~m}^{2}$

Maquinário $=1.780,00 \mathrm{~m}^{2}$

Espaço para servidor, computadores e maquinas

Salas de Aula $=1.080,00 \mathrm{~m}^{2}$

3 anfiteatros para 110 alunos com 1 computador para cada 2 alunos

3 anfiteatros para 130 alunos com mesa de demonstração

3 salas de aula para 60 alunos

Sala de Professores $=570,00 \mathrm{~m} 2$

Sala de Alunos de pós-graduação $=700,00 \mathrm{~m} 2$

\section{NÚCLEOS DE APOIO $=5.200,00 \mathrm{~m}^{2}$}

Núcleo de Estudos Avançados $=400,00 \mathrm{~m}^{2}$

Núcleo de Assistência ao Estudante $=100,00 \mathrm{~m}^{2}$

Núcleo de Informação e Biblioteca $=3.000,00 \mathrm{~m} 2$

Núcleo de Criatividade, Inovação e Experimentação $=500,00 \mathrm{~m}^{2}$

Núcleo de Cognição $=1.200,00 \mathrm{~m}^{2}$

\section{OUTRAS ATIVIDADES $=61 \cdot 200,00 \mathrm{~m}^{2}$}

Estacionamentos para 2.300 vagas $=46.000,00 \mathrm{~m}^{2}$ (não computáveis nos índices urbanísticos)

Refeitório $=1.000,00 \mathrm{~m}^{2}$

Refeitório mensal para 500 pessoas

Refeitório tipo buffet para 100 pessoas

Anfiteatros $=1.000,00 \mathrm{~m}^{2}$

1 Anfiteatro para 500 pessoas

1 Anfiteatro para 100 pessoas próximo ao núcleo de estudos avançados

Residências para estudantes $=6.000,00 \mathrm{~m} 2$ 
Para atender 500 alunos

Centro Cultural $=3.600,00 \mathrm{~m}^{2}$

1 Teatro

Dois cinemas

Livraria

Copiadora

Papelaria

Pequenas lojas

Centro Esportivo $=3.600,00 \mathrm{~m}^{2}$

1 Quadra Poliesportiva

Piscina semi-olímpica

Piscina de recreação

\section{RESUMO DAS ÁREAS :}

1. Corpo Administrativo $=940,00 \mathrm{~m}^{2}$

2. Corpo Docente $=6.800,00 \mathrm{~m}^{2}$

3. Corpo Discente

Ciências Naturais $=7.930,00 \mathrm{~m}^{2}$

Engenharias $=9.730,00 \mathrm{~m}^{2}$

Matemática e Cognição $=4.730,00 \mathrm{~m}^{2}$

4. Núcleos de Apoio $=5.200,00 \mathrm{~m}^{2}$

5. Outras Atividades $=61.200,00 \mathrm{~m}^{2}$

TOTAL $=96.530,00 \mathrm{~m}^{2}$

\section{VI - FLUXOGRAMA}




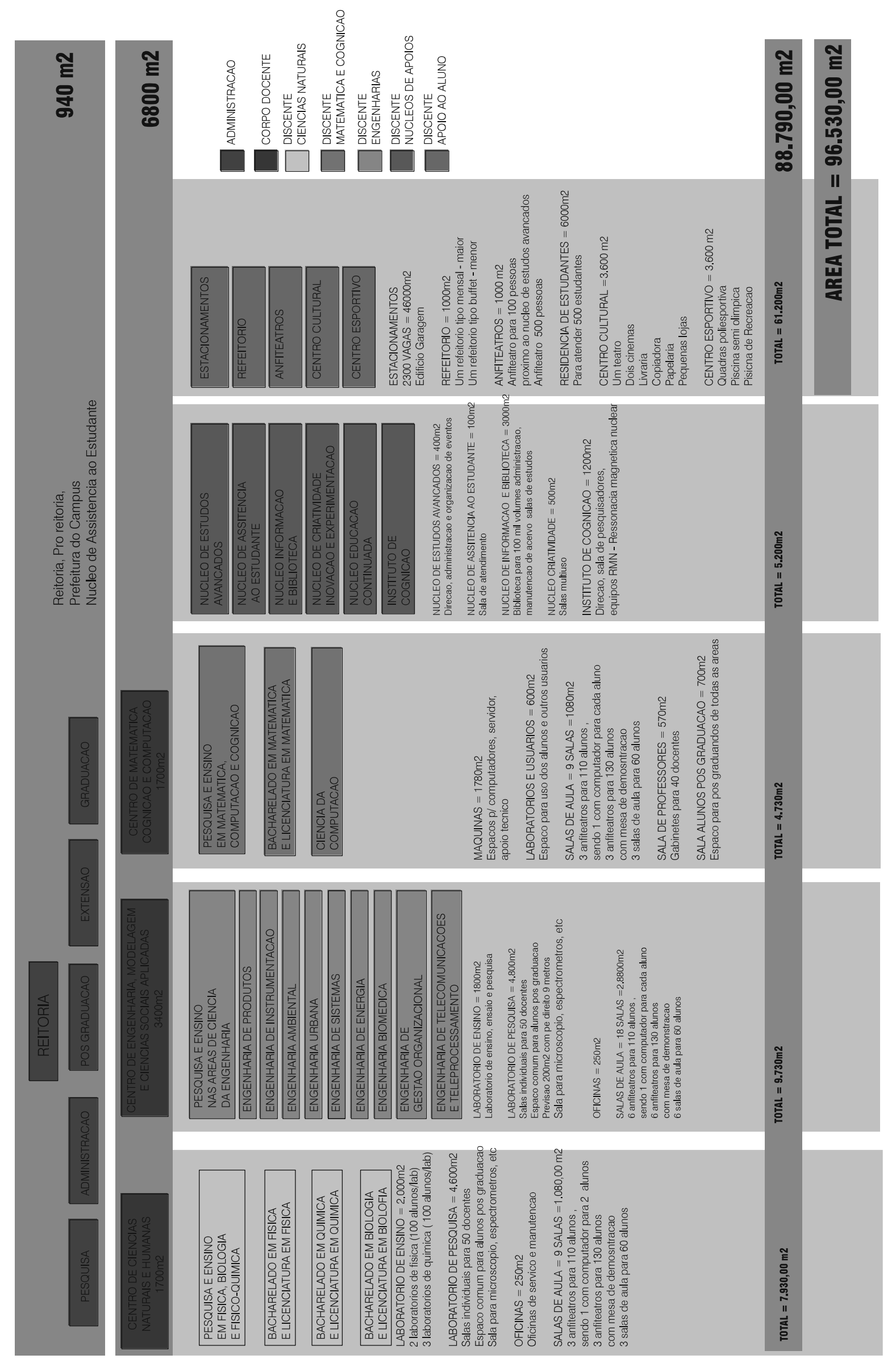


ANEXO E

MINUTA TERMO DE REFERÊNCIA

EDITAL PROJETOS SÃO BERNARDO 


\title{
MINISTÉRIO DA EDUCAÇÃO \\ FUNDAÇÃO UNIVERSIDADE FEDERAL DO ABC \\ PRÓ-REITORIA DE ADMINISTRAÇÃO \\ COMISSÃO ESPECIAL DE LICITAÇÃO
}

Processo $n^{\circ} .23006 .000232 / 2008-79$

\section{ANEXO I \\ NORMAS E DIRETRIZES TÉCNICAS PARA EXECUÇÃO DO OBJETO}

OBJETO:

\author{
PROJETOS COMPLETOS PARA A IMPLANTAÇÃO DO CAMPUS DA \\ UNIVERSIDADE FEDERAL DO ABC EM SÃO BERNARDO DO \\ CAMPOISP
}

Área do Terreno: $\quad 120.349,75 \mathrm{~m}^{2}$.

1. APRESENTAÇÃO

1.1. PRECEDENTES

1.2. A UNIVERSIDADE FEDERAL DO ABC

\section{SUMÁRIO}
2.1. Introdução
2.2. Do Objeto
2.3. Do Terreno
2.4. Dos Métodos e Técnicas. Critérios Gerais
2.5. Da Urbanização. Programa de Necessidades
2.6. Dos Edifícios. Programa de Necessidades
2.7. Quadro Resumo de Áreas
2.8. Diretrizes para Projetos Complementares
2.9. Legislações e Normas Técnicas
2.10. Anexos do Edital
2.11. Relatório Fotográfico

\section{APRESENTAÇÃO}

\subsection{Precedentes}

Reconhecendo o papel estratégico das universidades para o desenvolvimento econômico e social, o governo federal adotou uma série de medidas com o objetivo de retomar o crescimento do ensino superior público.

Assim, a expansão das Instituições Federais de Educação Superior (IFES) tornou-se uma das metas atuais do Ministério da Educação (MEC). Desde 2003 têm sido feitos investimentos, com aumento de recursos para custeio das instituições federais, recomposição do quadro de professores e implantação de quadro de carreira para servidores técnico-administrativos.

Além de melhorar as condições das IFES existentes, estão aplicando recursos para criação de novas instituições, na expectativa de estender a influência das universidades federais a todo o País. A interiorização tem sido uma das principais diretrizes norteadoras do mapa dessa expansão, ao lado das necessidades e das vocações econômicas das diversas regiões. Novas universidades e novos campi têm sido criados para promover a produção de conhecimento e a qualidade de vida.

Dentro dessa proposta de expansão da educação superior pública, estão sendo criadas nove universidades federais - algumas totalmente novas - outras por desmembramento de instituições e, outras, ainda pela transformação de faculdades isoladas em universidades. Além dessas universidades, o MEC está criando ou consolidando $36 \mathrm{campi}$, possibilitando o acesso a um número muito maior de brasileiros e ampliando a influência benéfica da universidade em todos os estados. 


\section{손 \\ MINISTÉRIO DA EDUCAÇÃO \\ FUNDAÇÃO UNIVERSIDADE FEDERAL DO ABC \\ PRÓ-REITORIA DE ADMINISTRAÇÃO \\ COMISSÃO ESPECIAL DE LICITAÇÃO}

Processo $n^{\circ} .23006 .000232 / 2008-79$

A região do $A B C$ apresenta uma enorme demanda de vagas no ensino público superior. Com efeito, a região possui mais de 2,5 milhões de habitantes e uma oferta de 45.000 vagas distribuídas em 30 Instituições de Ensino Superior, sendo a grande maioria privada. Nasceu aí a iniciativa da implantação da Universidade Federal do ABC (UFABC).

\subsection{A Universidade Federal do ABC}

A UFABC é uma das primeiras universidades federais brasileiras inauguradas no século XXI. Desta forma, nasce com forte potencial para a inovação e a diversificação propondo uma estrutura com flexibilidade acadêmica e curricular e, também, com altos padrões de qualidade.

Ela está sendo instalada em um sistema integrado por vários campi, ou seja, seu conceito multicampi, conforme a Lei 11.145 de 26 de julho de 2005. Em janeiro de 2007 a UFABC iniciou a obra do campus de Santo André, com área construída total de $96.000 \mathrm{~m}^{2}$, para acolher 10.000 alunos, localizado na Avenida dos Estados em Santo André, SP.

Já o campus São Bernardo - cujo projeto urbanístico e arquitetônico é objeto do presente Edital - está por ser construído no município de São Bernardo do Campo, SP, para comportar cerca de 3.000 alunos (em dois períodos), 240 docentes e 120 funcionários.

\section{SUMÁRIO}

\subsection{INTRODUÇÃO}

A elaboração do indispensável projeto completo - envolvendo a Arquitetura e as Engenharias necessárias - tal como é previsto e suficientemente delineado nos requisitos técnicos constantes do presente Anexo I do Edital, deverá fixar a soma das soluções orgânicas imprescindíveis à correta orientação da conseguinte licitação das obras e dos equipamentos, da construção, da implantação Universidade Federal do ABC em São Bernardo do Campo, SP.

Espera-se que a totalidade das condições físicas da Urbanização e das Edificações, assim previamente definidas e harmonizadas tanto em pormenor como em conjunto, influirão eficazmente para a requerida satisfação dos usuários - alunos, professores e funcionários durante as atividades curriculares de ensino, aprendizagem e pesquisa, assim como as extracurriculares e culturais. E - mais ainda - para fortalecer a dignidade, a imagem, o sentimento de pertença e orgulho, além do merecido prestígio da universidade brasileira e do próprio país.

\subsection{DO OBJETO}

O presente certame - estabelecido pelo Edital de Concorrência UFABC/SBC N ${ }^{\circ}$. 01/2008 e seus Anexos, conforme as especificações e os procedimentos técnicos e programáticos expressamente determinados neste Anexo I - e regido pela Lei federal $\mathrm{N}^{\circ} 8.666$ de 23 de junho de $1.993 \mathrm{e}$ legislação correlata - tem por objeto a execução dos projetos completos para a implantação do Campus de São Bernardo do Campo, selecionando empresas que apresentem profissionais de reconhecida capacidade técnica para subseqüente contratação da empresa vencedora para o seu desenvolvimento completo, visando fixar as informações técnicas necessárias à licitação e à execução das obras em referência.

\subsection{DO TERRENO}

Para viabilizar a implantação do novo Campus, o MEC e a UFABC adquiriram o terreno localizado na altura do $\mathrm{Km} 17$ da marginal esquerda da Via Anchieta, antes pertencente à Prefeitura do Município de São Bernardo do Campo (PSBC), SP. 


\section{슬 \\ MINISTÉRIO DA EDUCAÇÃO \\ FUNDAÇÃO UNIVERSIDADE FEDERAL DO ABC \\ PRÓ-REITORIA DE ADMINISTRAÇÃO \\ COMISSÃO ESPECIAL DE LICITAÇÃO}

Processo n. 23006.000232/2008-79

De grandes proporções, a gleba configura um vazio inserido em tecido urbano já consolidado, entre a Via Anchieta, a Oeste, e a futura Faculdade de Direito de São Bernardo, a Leste. Portanto, em região bastante valorizada, e próxima do Parque Cidade de São Bernardo Raphael Lazzuri.

A área total perfaz $120.349,73 \mathrm{~m}^{2}$, (cento e vinte mil e trezentos e quarenta e nove metros quadrados) composto pelas áreas A, B, C e D - conforme é apresentado nos Anexo III e Anexo IV:

- Área A: $17.972,37 \mathrm{~m}^{2}$

- Área B: $24.123,00 \mathrm{~m}^{2}$

- Área C: $41.827,36 \mathrm{~m}^{2}$

- Área D: $36.427,00 \mathrm{~m}^{2}$

A composição destas áreas, também pode ser visualizada através da Figura abaixo.

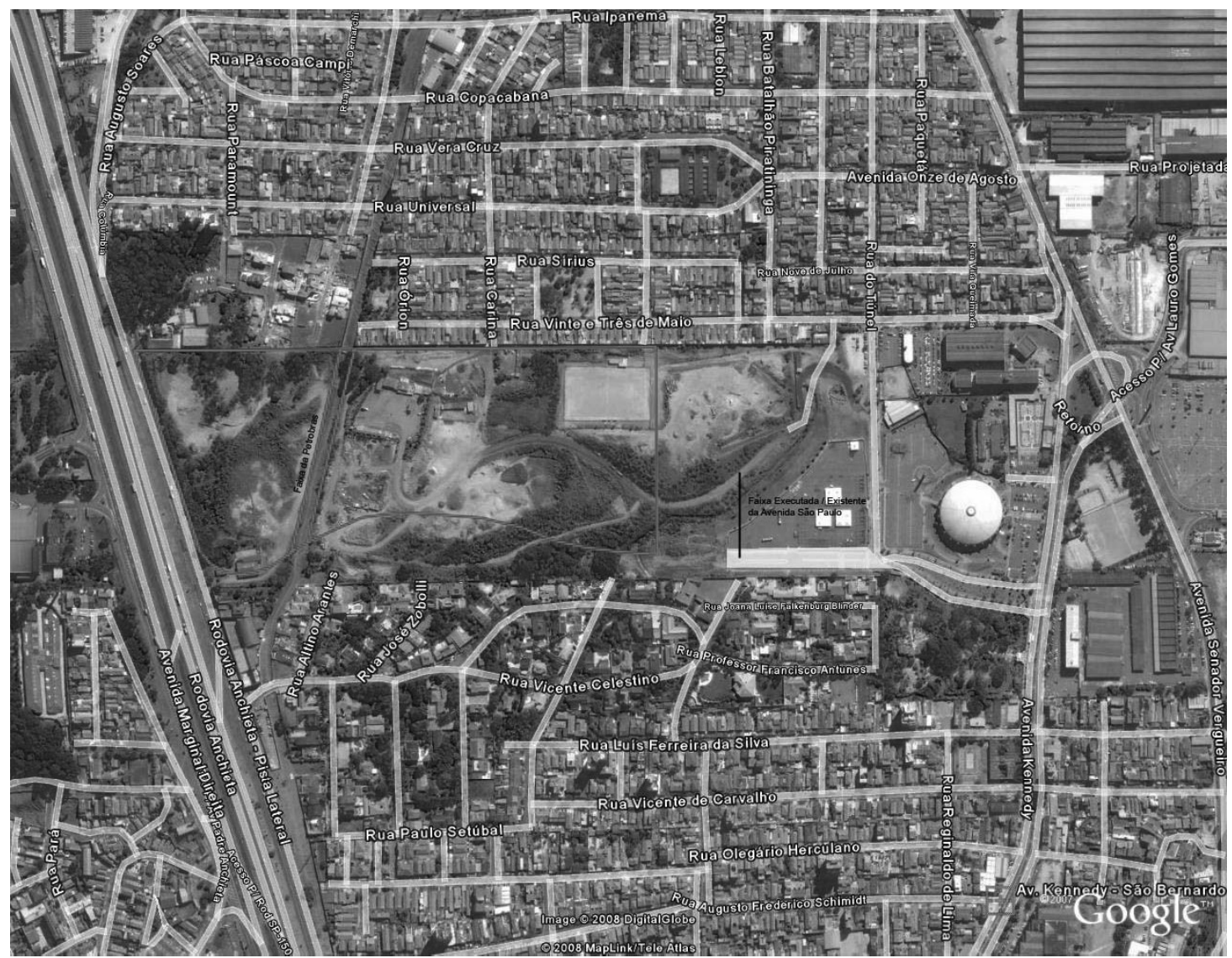

Localização do terreno do futuro Campus em São Bernardo do Campo, SP. Verificar Relatório Fotográfico no subitem 2.10 deste Anexo.

O projeto deverá considerar integradas estas áreas em uma só gleba, posto que as mesmas deverão ser remembradas na ocasião da aprovação dos respectivos projetos legais, na PSBC.

Na porção sul está prevista a construção de um complexo viário, que faz parte do Plano de Transportes Urbanos (PTU) da PMSBC que determina - mediante o prolongamento da Av. São Paulo - a criação de grandes vias, assim como de um túnel que atravessará a Via Anchieta, interligando os bairros. 


\section{슬 \\ MINISTÉRIO DA EDUCAÇÃO \\ FUNDAÇÃO UNIVERSIDADE FEDERAL DO ABC \\ PRÓ-REITORIA DE ADMINISTRAÇÃO \\ COMISSÃO ESPECIAL DE LICITAÇÃO}

Processo $n^{\circ} .23006 .000232 / 2008-79$

Não há - até o presente momento - informações precisas e definitivas sobre a configuração destas obras do PTU, assim como quanto à data de seu inicio e de sua inauguração. Assim sendo, o projeto do Campus deverá determinar - como única solução ora viável - como acesso principal ao Campus, o prolongamento da Av. São Paulo que for necessário.

Dentre as particularidades e acidentes notáveis do terreno, destaca-se a presença de uma faixa reservada a um oleoduto em operação, de propriedade da Empresa Petrobras - Transpetro. Ela ocupa aproximadamente $3.000 \mathrm{~m}^{2}$. Assim, em decorrência de normas de segurança, as obras lindeiras que forem propostas no projeto do Campus deverão ser analisadas e aprovadas por aquela empresa, em ocasião oportuna, conforme as instruções constantes do Anexo VI.

$\mathrm{Na}$ parte oeste do terreno, há um maciço florestal remanescente de Mata Atlântica. Qualquer intervenção na vegetação existente, desde que aprovada pela equipe técnica da UFABC, deverá ser submetida à apreciação do Departamento Estadual de Proteção dos Recursos Naturais (DEPRN), do Departamento de Licenciamento e Avaliação Ambiental (SHAMA 3) da PSBC e demais órgãos que se fizerem necessários. Verificar Anexo V.

\subsection{DOS MÉTODOS E TÉCNICAS. CRITÉRIOS PARA PROJETO}

O partido geral do projeto deve fixar uma identidade esteticamente referida, ensejando uma imagem condizente com a importância e o prestígio da instituição, pela qualidade da Urbanização e das Edificações. Ou seja, conferir a dignidade que deve ser normalmente requerida para empreendimentos de tal natureza e magnitude, sobretudo quando promovidos pelo Estado. A expectativa é que os investimentos públicos a serem feitos resultem em obras exitosas e exemplares, economicamente viáveis, que logo possam ser apreciadas tanto pela qualidade estética quanto pela sua contribuição ao desenvolvimento da cultura.

As propostas de projeto devem considerar que, devido à acelerada dinâmica e ao progressivo desenvolvimento científico e tecnológico, em conseqüência de novas constatações empíricas e à emergência de idéias inovadoras, as determinações dos programas de necessidades para a Urbanização e para as Edificações constantes deste Edital não podem ser cabal e definitivamente fixadas em termos absolutamente rígidos, apenas voltados para as rotinas acadêmicas comuns ou para atender a planos pedagógicos correntes, e facilmente superáveis. Portanto, a própria configuração final em urbanismo e em arquitetura, dentro de possibilidades razoavelmente defensáveis e justificadas, não deverá representar empecílho ou constrangimento àquela dinâmica mediante configurações físicas ou partidos arquitetônicos excessivamente comprometidos e sem remédio, ou seja, que logo possam tornar-se anacrônicos e obsoletos.

Assim, é imperioso que a concepção geral do projeto - em termos de racionalidade e de economia - proponha espaços e articulações que se caracterizem pela versatilidade e pela flexibilidade, isto é, possibilitem mudanças, adaptações, recomposições, rearranjos, rearticulações, ampliações ao longo do tempo. Assim, devendo ser, as especificações e os procedimentos do projeto deverão prever a configuração das Edificações de modo a possibilitar a progressiva ocupação por novos usuários em suas atividades curriculares e extracurriculares, e que a respectiva instalação ou remanejamento dos respectivos equipamentos não perturbe o funcionamento dos demais que já tiverem sido implantados e ocupados. Em resumo, são esperadas soluções:

- Formais, que possibilitem maior versatilidade ou flexibilidade ambiental e espacial para os usuários em suas atividades curriculares e extracurriculares, incluída a disposição do mobiliário e dos demais equipamentos e instalações, nos interiores ou no exterior;

- Construtivas, que possibilitem fácil adaptação ou remanejo em mudanças razoavelmente relevantes, obrigatórias, previsíveis ou prováveis, e evitem a necessidade de reformas radicais das estruturas ou das instalações (energia, ar condicionado, água, esgotos etc.) 


\section{(1) \\ MINISTÉRIO DA EDUCAÇÃO \\ FUNDAÇÃO UNIVERSIDADE FEDERAL DO ABC \\ PRÓ-REITORIA DE ADMINISTRAÇÃO \\ COMISSÃO ESPECIAL DE LICITAÇÃO}

Processo $n^{\circ} .23006 .000232 / 2008-79$

que possam causar prejuízos ou incontornáveis perturbações ou que constranjam a continuidade do bom funcionamento do Campus antes instalado e ocupado.

Durante a concepção da Urbanização e das Edificações previstas nos programas de necessidades (Urbanístico e Arquitetônico), é indispensável consultar as legislações municipal, estadual e federal, além das normas técnicas vigentes. Para os efeitos do presente Edital, devem ser preferidas e adotadas as hipóteses normativas mais rigorosas e exigentes. Nesses mesmos termos, deve ser considerada, sobretudo, a legislação ambiental quanto à ocupação antrópica, conseqüente impermeabilização do solo ou redução da mata original.

Em conformidade com a legislação municipal vigente, o dimensionamento do potencial construtivo do terreno designado limita as áreas de ocupação e de construção conforme consta neste Edital, Anexo $\mathrm{V}$, item $\mathrm{A}$.

No entanto, a UFABC, tendo em vista a limitação dos recursos financeiros ora disponíveis, para além das exigências indispensáveis às atividades previstas para o Campus em referência, nesta fase inicial, determina que não poderão ser ultrapassados $20.000 \mathrm{~m}^{2}$ (vinte mil metros quadrados) de construção referente aos blocos. Entretanto, as propostas de projeto urbanístico e arquitetônico devem assinalar e fazer constar claramente, nos desenhos e nos textos a apresentar, a orientação necessária e indispensável ao desenvolvimento futuro do Campus quanto a reservas de áreas no terreno e seu tratamento para uma ou mais fases futuras e subseqüentes de implantação e de ocupação:

- ampliações dos blocos já previstos;

- viabilidade construção de novos blocos;

- novas articulações viárias internas e externas;

- remanejamentos necessários.

Devem ser adotadas especificações e procedimentos cujas soluções resultantes privilegiem, em sua racionalidade, aspectos ou tópicos tais como:

- Facilidade e rapidez de produção ou de aquisição:

- Edificação (construção);

- Elementos da edificação;

- Componentes construtivos:

○ Materiais de construção;

- Desempenho:

- No uso (ergonomia, conforto, higiene, segurança);

Na operação;

- Na manutenção (conservação, limpeza, reposição);

- Economia:

- Custos equilibrados e compatíveis com os praticados na praça em obras de igual envergadura e semelhantes funções;

- Elementos, componentes construtivos e materiais de construção com propriedades econômicas, ou seja, com características de durabilidade e de desempenho nas condições normais de uso ao longo do tempo racionalmente estabelecido em projeto (considerar que a degradação de cada edifício por desgaste, deterioração, mau uso ou vandalismo terão de ser combatidos por atividades custosas de manutenção (limpeza, conservação, reposição);

- Uso eficiente da energia:

- Equipamentos com menor consumo de energia e melhor eficiência possível; 


\section{(1) \\ MINISTÉRIO DA EDUCAÇÃO \\ FUNDAÇÃO UNIVERSIDADE FEDERAL DO ABC \\ PRÓ-REITORIA DE ADMINISTRAÇÃO \\ COMISSÃO ESPECIAL DE LICITAÇÃO}

Processo $n^{\circ} .23006 .000232 / 2008-79$

- Transporte vertical automatizado com otimização de carga e menor consumo energético possível;

- lluminação de baixo consumo energético em todo o edifício nas áreas comuns de uso contínuo e iluminação "incandescente" com acionadores por sensor de presença nas áreas de uso esporádico ou intermitente;

- Planejamento do consumo energético e utilização de equipamentos para gerar energia em períodos de pico;

- Melhor aproveitamento da iluminação natural, levando em conta a necessidade do seu controle;

- Melhor condição de conforto térmico evitando a incidência da radiação solar direta mediante a adoção de soluções arquitetônicas de diversos tipos, tais como: brises-soleil, venezianas, telas termo-screen externas, prateleiras de luz, vidros especiais que dispensam o uso de brises;

- Ventilação natural, mesmo nos ambientes onde haja previsão para sistema de ar condicionado

- Adoção preferencial de acabamentos claros nas áreas de grande incidência de luz solar;

- Tratamento das coberturas dos edifícios mediante pinturas reflexivas para diminuir a absorção de calor para o edifício.

\section{- Uso eficiente da água:}

- Captação, armazenamento e tratamento de águas pluviais para reutilização na irrigação de jardins, limpeza, bacias sanitárias, refrigeração, sistema de combate a incêndio e demais usos permitidos para água não potável;

- Utilização de bacias sanitárias acopladas e válvulas especiais com o fluxo opcional por descarga, ou de sistemas a vácuo;

- Reaproveitamento das águas de lavagem, com tratamento local, para utilização sanitária;

- Utilização de torneiras com acionamento eletrônico ou temporizador por pressão em todas as aplicações passíveis.

- Uso de materiais certificados e renováveis:

- Maximização na especificação de materiais sustentáveis objetivando o maior volume possível de utilização de materiais certificados, de manejo sustentável e reciclável;

- Planejamento para maior durabilidade possível nas especificações visando alto desempenho e evitando obsolescência prematura;

- Utilização de materiais cujos processos de extração de matérias primas, beneficiamento, produção, armazenamento e transporte causem menor índice de danos ao meio ambiente nem estejam baseados em condições indignas para os trabalhadores

- Meio-ambiente; qualidade interna e externa:

- Espaços e sistemas visando impacto ambiental mínimo;

- Técnicas que permitam menos poluição e que impactem de forma menos agressiva o meio-ambiente, tanto na construção, como no uso, na operação, na manutenção (conservação, limpeza, reposição)

- Evitar, danos à fauna, flora, eco-sistema local e ao meio ambiente;

Minimizar a geração de lixo e resíduos;

Evitar contaminação, degradação e poluição de qualquer natureza, visual, sonora, atmosférica, luminosa;

- Promover a segurança interna e externa do edifício e de seus usuários;

- Otimizar os recursos para a correta coleta seletiva do lixo visando à reciclagem de materiais e a menor geração de resíduos descartáveis:

- Implantar plano eficiente de drenagem do solo para durante e após a execução das obras evitando danos tais como erosão ou rebaixamento nocivo de lençol freático 


\section{MINISTÉRIO DA EDUCAÇÃO \\ FUNDAÇÃO UNIVERSIDADE FEDERAL DO ABC \\ PRÓ-REITORIA DE ADMINISTRAÇÃO \\ COMISSÃO ESPECIAL DE LICITAÇÃO}

Processo $n^{\circ} .23006 .000232 / 2008-79$

- Acessibilidade: a Urbanização, os edifícios e seus ambientes devem possibilitar acessibilidade irrestrita a todos os usuários permanentes ou transitórios, alunos, professores ou funcionários, sobretudo às Pessoas Portadoras de Necessidades Especiais, de acordo com as normas técnicas vigentes, e dentro dos melhores princípios da Ergonomia e do Desenho Universal, principalmente quanto a:

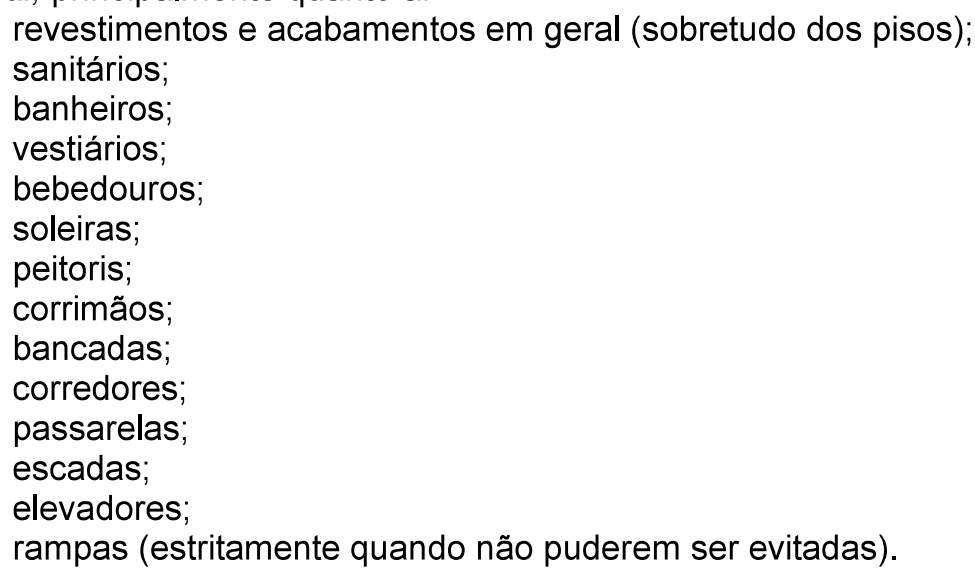

No Estudo Preliminar, deve ser apresentada uma tabela sumária de áreas, que demonstre com clareza os valores adotados para a capacidade final da gleba, tais como áreas a aproveitar e a preservar, áreas permeáveis, áreas de construção, densidades, taxas, proporções, índices, coeficientes, gabaritos etc, conforme descrito no Anexo II.

As indicações mínimas a assinalar nos desenhos de implantação são as áreas dos blocos a construir:

1. De construção, parciais e totais;

2. De ocupação, parciais e totais.

\subsection{DA URBANIZAÇÃO. PROGRAMA DE NECESSIDADES}

\subsubsection{CONDIÇÕES GERAIS}

Implantação, ocupação, uso

A qualidade do partido geral a ser adotado para a Urbanização é considerada como decisiva para a estruturação da totalidade dos ambientes/espaços em qualquer uma das etapas de construção ou fases de implantação e ocupação do Campus, até que seja atingida uma razoável capacidade máxima. Portanto, deve prevalecer o entendimento de que a estratégia inicial que for consagrada pelo desenho do Campus influenciará fortemente o enfrentamento dos problemas supervenientes, próprios de investimentos de mesma envergadura.

De qualquer modo, para a sustentação da Urbanização, o partido geral ou a estrutura espacial deve estabelecer, em sua configuração, as formas de ocupação e de uso de cada área que delimitar o potencial em áreas de construção, as condições de implantação, de localização e de ampliação.

O Campus deverá ser claramente setorizado para a implantação das Edificações e das áreas livres, de modo a que seja minimizado o impacto ambiental que possam acarretar já durante as respectivas obras. 


\section{들 \\ MINISTÉRIO DA EDUCAÇÃO \\ FUNDAÇÃO UNIVERSIDADE FEDERAL DO ABC \\ PRÓ-REITORIA DE ADMINISTRAÇÃO \\ COMISSÃO ESPECIAL DE LICITAÇÃO}

Processo $n^{\circ} .23006 .000232 / 2008-79$

As edificações previstas neste edital, contudo, devem se concentrar preferencialmente na parte leste do terreno, na área próxima ao acesso principal do campus, deixando áreas livres para se ter flexibilidade para a expansão da universidade.

\section{Novas unidades, ampliações}

A concepção da Urbanização deve disciplinar a expansão da ocupação dos terrenos destinados aos Edifícios ou às áreas livres que forem definidas dentro da gleba que constituirá o Campus. Visando a racionalidade e a economia de tal procedimento, deve ser claramente determinada uma estratégia para a implantação progressiva das ampliações e de novos Edifícios que forem possíveis ao longo de alguns anos, não só das unidades já previstas, mas também para o futuro. Ou seja, partes expressivas do terreno deverão permanecer como áreas livres reservadas para futuras intervenções.

Por conseguinte, e de preferência, essas previsões devem ser feitas igualmente quanto à infraestrutura viária e aos serviços necessários (água, esgotos, energia, iluminação, comunicação etc.).

Nesse mesmo sentido, a proposta técnica, ao considerar que, em qualquer fase de implantação e ocupação dos Edifícios, isto é, de eventuais novas unidades, de ampliações ou de adequações das unidades então já em uso, ou de novas áreas livres, as atividades de construção ou de manutenção deverão desenvolver-se de modo a não perturbar o desempenho acadêmico nem obrigar à paralisação quaisquer atividades universitárias.

\section{Solo}

A permeabilidade do solo deverá ser garantida, evitando-se pavimentação ou compactação excessiva, que possa derivar das obras de construção ou das futuras atividades do Campus, possibilitando assim o máximo de infiltração das águas pluviais no próprio terreno.

\section{Vegetação}

A vegetação nativa de porte arbóreo ou arbustivo deverá ser preservada ou recuperada, sobretudo as assinaladas pela orientação constante no Anexo V. A eventual compensação ambiental prevista em Lei, referente à supressão e replantio de vegetação, deverá ser feita preferencialmente no interior da própria gleba. O respectivo licenciamento e a execução serão definidos pela autoridade competente após a elaboração do Projeto Legal a ser realizado, em que deverão estar assinaladas com precisão as espécies a manter e as que eventualmente poderão ser manejadas.

\section{Praça de Convivência}

Os primeiros edifícios, deverão ser dispostos de modo a configurar uma grande praça, a ser concebida como referência fundadora. É desejo da UFABC que, já de início, demarquem ambiente um externo de convergência, atraente para uma estimulante e prazerosa convivência acadêmica. Este conjunto é propositado a estabelecer relações espaciais estruturadoras, que induzam os usuários às múltiplas possibilidades de contatos, sejam espontâneos ou propositados

Este primeiros edifícios que possuem esta relação de convivência, podem ser classificados como conjunto de ensino, e será composto pelo Blocos de Ensino, Laboratórios, Biblioteca e Anfiteatros, ou seja: $1,2,3$, e 4 .

Podemos classificar, também, o conjunto de pesquisa, o qual será composto pelos Blocos de Pesquisa e Engenharia; Pesquisa e Cognição e Computação Científica e Alto Desempenho, ou seja: 6,7 e 8. 


\section{흘 \\ MINISTÉRIO DA EDUCAÇÃO \\ FUNDAÇÃO UNIVERSIDADE FEDERAL DO ABC \\ PRÓ-REITORIA DE ADMINISTRAÇÃO \\ COMISSÃO ESPECIAL DE LICITAÇÃO}

Processo $n^{\circ} .23006 .000232 / 2008-79$

Estes conjuntos (ensino e pesquisa) devem possuir correlação com os blocos Refeitório e Administração.

Todos os edifícios, de acordo com os estudos preliminares, deverão estar localizados em uma área concentrada, de forma a deixar livre a maior área possível para futuras expansões da UFABC neste Campus.

\section{Passarela para Pedestres}

Por exigência do Departamento de Planejamento Estratégico da Prefeitura Municipal de São Bernardo, a proposta técnica deverá prever a construção de uma passarela para pedestres composta de rampas de acesso interligando as duas faixas de domínio da via Anchieta, defronte ao terreno destinado ao Campus. Portanto, o projeto do Campus também deverá prever e propor sendo necessária a prévia oitiva da DERSA:

- passarela de interligação e transposição da Via Anchieta, de forma a possibilitar o acesso de pedestres (alunos, docentes, funcionários e outros);

- paradas de ônibus nas Marginais Direita e Esquerda da Via Anchieta, na altura desta passarela, de modo a proporcionar diminuição de trajeto de transporte coletivo ao Campus e facilitar 0 acesso de pedestres.

\section{Ciclovia}

Deverá prever uma ciclovia de acordo com as normas técnicas da Federação Paulista de Ciclismo, de forma à permitir dentro do Campus:

- atividade esportiva, recreativa e de transporte;

- percurso agradável e lúdico entre os diversos setores.

\section{Acessos, vias, estacionamentos}

Os acessos de pedestres e veículos à gleba, incluindo entradas e saídas, deverão ser claramente separadas e facilmente controláveis. Também deverão ser compatíveis com os planos viários estadual e municipal existentes, de modo a que atendam às necessidades do Campus ocupação máxima completada. Por conseguinte, logo de início, independentemente do progresso da construção da Urbanização e das Edificações, deve ser prevista a movimentação de veículos de grande ou de pequeno porte, de passageiros ou de carga, além da segurança e do conforto dos pedestres.

Nesse sentido, e de acordo com as autoridades competentes, o projeto deverá determinar, no terreno, uma via de acomodação ou de desaceleração diante dos referidos acessos, de modo que, sem prejuízo do trânsito de pedestres, os veículos de qualquer dimensão possam — a partir da via pública - adentrar os terrenos ou sair sem conflitos e em segurança.

As condições de acessibilidade e de mobilidade no interior da gleba deverão ser garantidas para que sejam evitadas e dificultadas as paradas e a permanência de veículos ou de pessoas nas vias públicas que darão acesso ao Campus. Isso deve ser estabelecido fisicamente, visando coibir ou desestimular a instalação e o funcionamento, em áreas externas e próximas, de instalações comerciais precárias de ambulantes, tais como barracas, carroças ou feiras muito costumeiras diante de estabelecimentos educacionais.

Os estacionamentos, as áreas verdes e as praças de convivência devem desempenhar papel relevante na planta de Urbanização. 


\section{돈 \\ MINISTÉRIO DA EDUCAÇÃO \\ FUNDAÇÃO UNIVERSIDADE FEDERAL DO ABC \\ PRÓ-REITORIA DE ADMINISTRAÇÃO \\ COMISSÃO ESPECIAL DE LICITAÇÃO}

Processo $n^{\circ} .23006 .000232 / 2008-79$

Para orientação e dimensionamento quanto ao número de vagas, devem ser consultadas as Diretrizes da PMSBC - Anexo V do presente Edital.

Pela legislação vigente, a capacidade das áreas que forem designadas para os estacionamentos de veículos depende da prévia determinação da população usuária a ser formada pelos funcionários e pelos alunos. Assim, não havendo outro modo mais preciso, ela deverá ser definida em função daquelas Diretrizes da PMSB. Portanto, para possibilitar maior exatidão, os dispositivos legais devem ser consultados e verificados, considerando, sobretudo, os relativos ao ambiente universitário e à preservação ambiental.

$\mathrm{Na}$ forma da legislação municipal, deverão ser previstas a vagas para estacionamento de veículos leves de passageiros, de modo a que possam servir os alunos, os docentes e os demais funcionários. Essas vagas deverão ser calculadas na proporção de uma vaga para cada dois usuários. De todo modo, deverá ser estimulado à preponderância da forma do transporte coletivo de passageiros, de modo a que, na prática, as áreas de estacionamento sejam menos sobrecarregadas. As pessoas portadoras de necessidades especiais deverão ter as prioridades já consagradas.

Para os veículos coletivos de passageiros, tais como os ônibus e os lotações tipo "van", devem ser previstas áreas de acostamento necessárias às paradas para entrada ou à saída dos usuários. Para um reduzido número desses veículos, especialmente os alugados, poderá ser permitido que os estacionem dentro do Campus, de preferência na proximidade da entrada principal.

Os caminhões somente poderão estacionar o tempo indispensável para carga e descarga nos locais necessários aos serviços internos de manutenção e de segurança.

A totalidade dessas áreas destinadas a estacionamentos deverá ser distribuída e acomodada para atender os usuários das diversas edificações sem que constituam bloqueio físico ou perturbar a desejada convivência universitária.

\section{Atividades nas áreas livres}

Algumas atividades curriculares e extracurriculares deverão ter condições de desenvolvimento tanto no interior dos Edifícios, como nas áreas livres, descobertas, mas preparadas do ponto de vista paisagístico para tal. Nesse sentido, deverão ser assinaladas as áreas a destinar para atividades culturais e de lazer, assim como para espetáculos, jogos, danças, lutas e ginástica que possam ser praticadas a céu aberto.

\section{Proteções. Segurança}

Deverão ser definidas e representadas as soluções que forem consideradas indispensáveis à proteção do Campus, na forma de muros ou gradis, além da iluminação exterior, e facilitar aos serviços de segurança para um controle satisfatório dos acessos, visando desestimular e impedir a intrusão de estranhos e o vandalismo, tanto durante o dia como à noite.

\subsubsection{CONDIÇÕES ESPECÍFICAS}

\section{Áreas livres}

Para a Urbanização, devem ser determinadas as seguintes partes:

- Plano viário: 


\section{MINISTÉRIO DA EDUCAÇÃO \\ FUNDAÇÃO UNIVERSIDADE FEDERAL DO ABC \\ PRÓ-REITORIA DE ADMINISTRAÇÃO \\ COMISSÃO ESPECIAL DE LICITAÇÃO}

Processo $n^{\circ} .23006 .000232 / 2008-79$

- a circulação de pedestres será prioritariamente separada da circulação de veículos:

- acessos:

- via de desaceleração ou acomodamento (na entrada);

- abrigos para guardas de segurança e controle;

- portões e portas;

proteções (grades, muros, sebes, anteparos etc.);

avenidas, ruas, rotatórias, cul de sac;

passeios;

praças secas;

jardins;

bosques;

estacionamentos para automóveis, ônibus e lotações;

acostamentos com abrigos para passageiros de ônibus e lotações;

etc.

- Zoneamento, setores:

- usos e ocupações (quando possível, para as fases subseqüentes de implantação)

- permeabilidade local.

- Diretrizes genéricas e específicas, conforme o caso;

- preservação e sustentação do meio, reservas e recuperação da mata original

- diretrizes para as praças e os jardins etc.;

- diretrizes para o calçamento e para os passeios etc.;

- proteções contra a intrusão (esquemas).

\section{Blocos. Etapas de construção e fases de implantação e ocupação}

Tendo em vista a orientação e determinações da UFABC, as funções do Campus referentes ao abrigo físico dos usuários, das suas respectivas atividades e equipamentos, conforme as suas características, poderão ser desempenhadas em ambientes fechados (interiores) ou em ambientes abertos (exteriores) conforme são estabelecidos no presente Edital.

Os vários Edifícios designados neste Edital, assim como as áreas exteriores, estão nomeados e especificados por blocos e suas funções principais ou mais relevantes, de modo a instruir a concepção da proposta do projeto.

Os blocos especificados no presente Edital serão construídos em uma só etapa.

$O$ acesso à Praça de Convivência e aos blocos deve dar-se por um eixo principal de circulação de pedestres que deverá interligar o conjunto.

- Portaria Principal

- Praça de Convivência

- Bloco 1: Ensino

- Bloco 2: Laboratórios Didáticos

- Bloco 3: Biblioteca e Salas de Estudo

- Bloco 4: Anfiteatro

- Bloco 5: Refeitório

- Bloco 6: Laboratórios de Pesquisa em Engenharia e Docentes

- Bloco 7: Laboratórios de Pesquisa em Ciências da Cognição e Sistemas Complexos

- Bloco 8: Laboratórios de Computação Científica e de Alto Desempenho

- Bloco 9: Administração

- Bloco 10: Apoio Esportivo

- Portarias Secundárias 


\section{돈 \\ MINISTÉRIO DA EDUCAÇÃO \\ FUNDAÇÃO UNIVERSIDADE FEDERAL DO ABC \\ PRÓ-REITORIA DE ADMINISTRAÇÃO \\ COMISSÃO ESPECIAL DE LICITAÇÃO}

Processo $n^{\circ}$. 23006.000232/2008-79

\subsection{DOS EDIFÍCIOS. PROGRAMA DE NECESSIDADES}

\subsubsection{CONDIÇÕES GERAIS}

\section{Área de construção}

As especificações arquitetônicas deverão limitar-se às áreas de construção expressamente estabelecidas no presente Programa de Necessidades, totalizando o máximo de $20.000 \mathrm{~m}^{2}$ (vinte mil metros quadrados). Conforme as determinações oficiais, esta área será construída em uma só Etapa, mediante licitação da obra que será iniciada ainda na gestão de 2009.

\section{Funções ambientais/espaciais}

Os ambientes acadêmicos em geral, sobretudo as salas de aula comuns e os laboratórios de ensino, deverão possibilitar o acesso e o uso indistintamente por parte de professores e alunos de qualquer curso, competência ou série. A sua ocupação poderá ser redefinida pelo Conselho Universitário a qualquer tempo, mediante programação que reflita o projeto pedagógico, a grade curricular e número de turmas de alunos a atender. Desse modo, não haverá fixação prévia, rígida e definitiva das atividades ou dos usuários permanentes de cada um desses ambientes.

Os ambientes dos laboratórios de ensino, assim como os de pesquisa, devem comportar atividades diversificadas, multi-funcionalidade e versatilidade para uso e ocupação.

Os professores devem ser instalados em pequenos grupos, em salas privativas e de reunião muito próximas, sobretudo dos laboratórios de pesquisa (aos quais somente alguns alunos e professores terão acesso livre) e também próximo dos laboratórios de ensino (onde estarão livremente os alunos e professores em geral).

Desse modo, devem ser buscadas e obtidas condições ambientais / espaciais que possibilitem uma convivência e uma integração de todos os usuários em ambientes acolhedores, estimulantes e agradáveis e, ainda, que permitam o mais livre acesso direto dos alunos aos professores dedicados a tarefas didáticas ou de pesquisa.

As Edificações e os ambientes abertos destinados às seguintes funções, preferencialmente e sempre que possível, deverão ser articulados de modo a que possam ser usados com ampla versatilidade, e facilitar a convergência e o encontro propositado ou casual dos alunos e dos docentes, em diferentes momentos do dia:

- culturais;

- de alimentação.

- de apoio acadêmico;

- de convivência;

- de lazer;

- esportivas.

Os serviços de apoio e de convivência, em geral, devem ser instalados para garantir, sobretudo, a alimentação, de modo a evitar que alunos, professores e demais servidores sejam constrangidos a retirar-se para buscar esses serviços sistematicamente fora do Campus. É prevista a construção das cantinas que forem necessárias ao bom atendimento mediante refeições rápidas. Elas devem ser equilibradamente distribuídas no espaço do Campus, por um critério que considere a comodidade e a proximidade com os diferentes ambientes. 


\section{돈 \\ MINISTÉRIO DA EDUCAÇÃO \\ FUNDAÇÃO UNIVERSIDADE FEDERAL DO ABC \\ PRÓ-REITORIA DE ADMINISTRAÇÃO \\ COMISSÃO ESPECIAL DE LICITAÇÃO}

Processo n. 23006.000232/2008-79

\section{Sobre os ambientes/espaços}

As exigências quanto aos sanitários e aos vestiários estão assinaladas no presente Edital apenas quanto à sua distribuição em cada bloco ou conjunto funcional de ambientes, pois o seu dimensionamento preciso, o seu número e a sua localização deverão ser definitivamente determinadas a partir da legislação municipal. A distribuição dos mesmos deve ser determinada na proposta, considerando que 0 acesso às unidades destinadas ao atendimento das Pessoas Portadoras de Necessidades Especiais deverá ser feito pelo interior de cada conjunto de sanitários comuns, masculinos e femininos.

Os laboratórios de pesquisa, de preferência, devem ser situados na proximidade das áreas destinadas às salas privativas dos docentes pesquisadores e salas de reuniões. Não há obrigatoriedade de iluminação natural direta, mas é desejável a iluminação natural indireta.

Deve ser previsto condicionamento artificial, com flexibilidade e possibilidade de individualização das condições de cada ambiente. Devem ser previstas facilidades usuais tais como rede de gases, vácuo, água purificada, e suas redes de distribuição bem como, contenção de resíduos perigosos onde for necessário. A flexibilidade das instalações deve permitir alterações de lay-out sem grandes perturbações aos usuários de salas próximas. Todos os laboratórios devem ser controlados, de modo a impedir o acesso de pessoas não autorizadas.

\section{Padronização dimensional. Módulos}

Os ambientes, em geral, serão dimensionados conforme o presente Edital e a legislação vigente. Além disso, deverão ser dimensionados mediante módulos planimétricos. Para a obtenção de uma racionalidade dimensional e construtiva, assim como uma razoável unidade plástica entre as edificações previstas e as demais Edificações das futuras fases de implantação do Campus, preferencialmente, deve ser especificado, em planimetria, o módulo de $1,20 \mathrm{~m} \times 1,20 \mathrm{~m}$ a contar dos eixos de locação das paredes dos ambientes e dos demais elementos ou componentes fortemente caracterizadores. Desse modo, as dimensões de todos os ambientes deverão ser múltiplas desse módulo comum $\left(1,44 \mathrm{~m}^{2}\right)$.

Alguns ambientes devem ser padronizados obrigatoriamente, dimensionados de modo modular, a exemplo dos seguintes:

- salas de aula comuns;

- laboratórios;

- salas privativas dos docentes;

- sanitários;

- vestiários;

- banheiros.

Quanto às salas de aula, a maior dimensão de cada um desses ambientes deve coincidir com o plano da fachada, isto é, a menor dimensão deve ser a da profundidade, perpendicular ao plano da fachada, de modo a aproveitar melhor a iluminação natural que, no caso, deve chegar pela esquerda dos alunos sentados e voltados para o quadro negro ou "green board".

Os laboratórios de ensino devem ser dimensionados com base em módulos de $3,60 \mathrm{~m}$, e previstos a instalação de bancadas duplas perpendiculares ao sentido da luz natural. A iluminação deve ser preferencialmente indireta.

Os laboratórios de pesquisa devem ser dimensionados com base em módulos de 3,60m. 


\section{들 \\ MINISTÉRIO DA EDUCAÇÃO \\ FUNDAÇÃO UNIVERSIDADE FEDERAL DO ABC \\ PRÓ-REITORIA DE ADMINISTRAÇÃO \\ COMISSÃO ESPECIAL DE LICITAÇÃO}

Processo n. 23006.000232/2008-79

\section{Pavimentos/Circulação Vertical}

Sempre que possível, a solução arquitetônica a apresentar na proposta, deve preferir a configuração de uma ambiência predominante horizontal, isto é, em que os blocos a construir sejam limitados a poucos pavimentos. As Edificações não deverão ter mais do que 4 (quatro) pavimentos. A adoção de até três pavimentos é recomendada pela UFABC, se essa solução for racional e economicamente justificada em face da não recomendação das rampas $e$ da conseqüente necessidade dos elevadores como solução imperativa para a circulação vertical. Com exceção do Bloco 8 - de Laboratórios de Computação Científica e de Alto Desempenho, o qual deverá ser em pavimento térreo.

Nas prumadas de circulação vertical deve ser evitada a especificação de rampas uma vez que, conforme a norma técnica vigente, essa solução exige uma grande área de construção adicional considerada muito onerosa. (Consultar a NBR 9050).

Por conseguinte, uma vez que as Edificações terão, de preferência, poucos pavimentos, é imperativa a especificação de escadas bem localizadas, conjugadas com elevadores. A especificação dos elevadores deve ser determinada com prudência, para que seja evitada a necessidade da instalação de um número elevado de unidades, a ser técnica e economicamente justificado tendo em vista não só os custos iniciais como, também, os da operação e da manutenção, de difícil e custosa administração.

\section{Pés direitos}

Os pés direitos dos laboratórios, sobretudo os destinados a pesquisas, devem ser especificados de maneira a que esses ambientes possam comportar com razoável versatilidade instalações diversificadas nos tetos e nos pisos. As soluções também devem ser adequadas para a instalação e a manutenção dos equipamentos especiais necessários ao controle ambiental. A especificação dos equipamentos específicos dos laboratórios de pesquisa será discutida com técnicos da UFABC durante a elaboração dos Estudos Preliminares.

Para os demais ambientes, a legislação deve ser consultada.

\section{Estruturas portantes}

Para os Edifícios em geral, de preferência, deve ser considerada a adoção de sistema construtivo em pré-fabricado de concreto armado conforme os requisitos de economia dos seus diferentes componentes. Para os Edifícios que devam desempenhar funções especiais e que devam contar com maior destaque simbólico, poderá ser adotada outra solução, previamente aprovada pela UFABC.

Para os laboratórios de Pesquisa em Engenharia; Cognição e Sistemas Complexos e Computação Científica e de Alto Desempenho - blocos 6, 7 e 8 - sugere-se o uso de estrutura de concreto armado convencional, por exigir um isolamento vibracional adequado às atividades a eles pertinentes.

Todas as edificações devem ser concebidas em planta livre, isto é, mediante solução estrutural independente das paredes divisórias e de fachada, que possibilite flexibilidade ou versatilidade na configuração física dos ambientes necessários, de modo que estes possam ocupar seus espaços de acordo com as demandas que se verificarem ao logo do tempo, permitindo assim, mudanças de layout quando necessário. 


\section{MINISTÉRIO DA EDUCAÇÃO \\ FUNDAÇÃO UNIVERSIDADE FEDERAL DO ABC \\ PRÓ-REITORIA DE ADMINISTRAÇÃO \\ COMISSÃO ESPECIAL DE LICITAÇÃO}

Processo $n^{\circ} .23006 .000232 / 2008-79$

\section{Higiene e Conforto}

De um modo geral, salvo para os casos em que características especiais ou relevantes devam ser observadas:

- fachadas sombreadas, onde necessário, conforme a orientação solar das fachadas;

- ventilação natural cruzada em todos os ambientes;

- instalação de ar condicionado em todos os ambientes de ensino, de estudo, administrativos e laboratórios.

Para que seja garantido o conforto higrotérmico em todos os ambientes fechados, sobretudo os referentes às atividades previstas para as salas comuns de aula (presencial ou não), a ventilação cruzada deverá ser especificada como solução geral, procurando, no entanto, garantir que o conforto acústico não seja prejudicado.

Todos os edifícios deverão prever condicionamento artificial, com flexibilidade e possibilidade de individualização das condições de cada ambiente. A orientação solar das fachadas deve evitar a entrada direta da luz sobre os planos de trabalho em geral. Também deve ser evitada a orientação noroeste, protegendo os ambientes da entrada da radiação solar durante as horas mais quentes do dia.

A especificação de quebra-sóis (brise-soleil), caso sejam necessários, deve evitar o obscurecimento dos ambientes que devem ser iluminados preferencialmente pela luz do dia.

\subsubsection{CONDIÇÕES ESPECÍFICAS}

\section{Bloco $01-$ Ensino $-2.800 \mathrm{~m}^{2}$}

A edificação destinada ao Ensino deverá ter as seguintes características:

- máximo de $2.800 \mathrm{~m}^{2}$ (dois mil e oitocentos metros quadrados) de construção;

- ter até 3 (três) pavimentos;

- para uso simultâneo em sala de aula de aproximadamente 720 (setecentos e vinte) alunos, além dos professores e funcionários;

- depósitos;

- shafts;

- ar condicionado nos ambientes de permanência prolongada;

- telecom - sala de apoio para rede de lógica/elétrica.

Os 3 (três) pavimentos e seus ambientes serão como adiante discriminados:

\section{Pavimento Térreo:}

- salas de aula, para 80 (oitenta) alunos cada,com possibilidade de algumas delas serem transformadas facilmente em salas de 40 (quarenta) alunos cada, com telas de projeção, aparelho projetor multimidia e sistema de sonorização;

- sanitários (masculino e feminino);

- ambiente para serviços diversos (pequeno comércio ou serviços);

- bebedouros;

- depósito;

- telecom - sala de apoio para rede de lógica/elétrica;

- circulação horizontal e vertical (elevadores e escadas). 


\section{MINISTÉRIO DA EDUCAÇÃO \\ FUNDAÇÃO UNIVERSIDADE FEDERAL DO ABC \\ PRÓ-REITORIA DE ADMINISTRAÇÃO \\ COMISSÃO ESPECIAL DE LICITAÇÃO}

Processo $n^{\circ}$. 23006.000232/2008-79

\section{$1^{\circ}$ Pavimento:}

- salas de aula, para 80 (oitenta) alunos cada,com possibilidade de algumas delas serem transformadas facilmente em salas de 40 (quarenta) alunos cada, com telas de projeção, aparelho projetor multimidia e sistema de sonorização;

- sanitários (masculino e feminino);

- depósito;

- bebedouros;

- telecom - sala de apoio para rede de lógica/elétrica;

- circulação horizontal e vertical (elevadores e escadas).

\section{$2^{\circ}$ Pavimento:}

- salas de aula, para 80 (oitenta) alunos cada,com possibilidade de algumas delas serem transformadas facilmente em salas de 40 (quarenta) alunos cada, com telas de projeção, aparelho projetor multimidia e sistema de sonorização;

- sanitários (masculino e feminino);

- bebedouros;

- depósito;

- telecom - sala de apoio para rede de lógica/elétrica;

- circulação horizontal e vertical (elevadores e escadas).

\section{Bloco 02 - Laboratórios Didáticos $-2.800 \mathrm{~m}^{2}$}

A edificação destinada aos Laboratórios deverá ter as seguintes características:

- para uso simultâneo de no mínimo 320 (trezentos e vinte) alunos em laboratórios, além dos professores e funcionários;

- máximo de $2.800 \mathrm{~m}^{2}$ (dois mil e oitocentos metros quadrados) de construção;

- 3 (três) pavimentos, sendo 2 (dois) de laboratórios;

- depósitos;

- sanitários (masculino e feminino);

- telecom - sala de apoio para rede de lógica/elétrica;

- instalações de gás e ar comprimido;

- ar condicionado;

- linha de capelas com sistema de exaustão independente;

- circulação horizontal e vertical (elevadores e escadas).

Os 3 (três) pavimentos e seus ambientes serão como adiante discriminados:

\section{Pavimento Térreo:}

- salas de estudo para 120 (cento e vinte) alunos em uso simultâneo, em tamanhos variados e distribuídos para grupos de 4 (quatro) a 30 (trinta) pessoas com ar condicionado e internet;

- área para serviços diversos (copiadora, lanchonete, agência bancaria, etc);

- sanitários (masculino e feminino);

- depósitos;

- telecom - sala de apoio para rede de lógica/elétrica;

- circulação horizontal e vertical (elevadores e escadas).

\section{Pavimento:}

- laboratórios de informática, para 40 (quarenta) alunos cada;

- sanitários (masculino e feminino);

- depósitos;

- telecom - sala de apoio para rede de lógica/elétrica; 


\section{MINISTÉRIO DA EDUCAÇÃO \\ FUNDAÇÃO UNIVERSIDADE FEDERAL DO ABC \\ PRÓ-REITORIA DE ADMINISTRAÇÃO \\ COMISSÃO ESPECIAL DE LICITAÇÃO}

Processo $n^{\circ} .23006 .000232 / 2008-79$

- circulação horizontal e vertical (elevadores e escadas).

$2^{\circ}$ Pavimento:

- laboratórios didáticos/experimentais para 40 (quarenta) alunos cada com bancadas centrais;

- prever 2 capelas por laboratório;

- prever para cada 2 laboratórios, 1 sala de monitoria;

- sanitários (masculino e feminino);

- depósitos;

- telecom - sala de apoio para rede de lógica/elétrica;

- Circulação horizontal e vertical (elevadores e escadas).

\section{Bloco 03 - Biblioteca/Salas de Estudo - $1.500 \mathrm{~m}^{2}$}

A edificação destinada à Biblioteca terá área construída de $1.500 \mathrm{~m}^{2}$.

O programa básico para este projeto pede:

- balcão de atendimento ao usuário

- salão de leitura com mesas de estudo com acesso a internet;

- salas de estudos individuais e em grupos

- espaço para acervo de livros, revistas, equip. digitais, etc.;

- espaço para cadastramento do acervo;

- administração;

- telecom - salas de apoio para rede de lógica/elétrica.

- copa;

- sanitários.

\section{Bloco 04 - Anfiteatro - $1.200 \mathrm{~m}^{2}$}

A edificação destinada ao Anfiteatro deverá ter as seguintes características:

Esta edificação será composta apenas por um pavimento construído. Deverá receber tratamento acústico e de sonorização adequado à sua finalidade, com a devida orientação de profissional especializado. Este bloco é destinado às atividades de ensino - aulas / palestras / seminários, etc.

O programa básico para o projeto desta edificação pede:

- três "salas anfiteatro" com capacidade para 130 pessoas cada;

- uma "sala anfiteatro de informática" para 120 alunos. Prever um computador por aluno;

- todas as salas contarão com telas de projeção, aparelho projetor multimídia e sistema de sonorização;

- sala de apoio para audio/video/sonorização e outros equipamentos;

- telecom - sala de apoio para rede de lógica/elétrica.

- área de convivência coberta (cantina, espaço de convivência,etc), para atender inclusive alunos dos blocos 1,2 e 3 ;

- $\quad$ sanitários (masculino e feminino).

Obs.: os blocos de 1 a 4 deverão estar interligadas por um mesmo espaço de convivência e formarão conjunto de ensino. 


\section{솔 \\ MINISTÉRIO DA EDUCAÇÃO \\ FUNDAÇÃO UNIVERSIDADE FEDERAL DO ABC \\ PRÓ-REITORIA DE ADMINISTRAÇÃO \\ COMISSÃO ESPECIAL DE LICITAÇÃO}

Processo $n^{\circ}$. 23006.000232/2008-79

\section{Bloco $05-$ Refeitório $-800 \mathrm{~m}^{2}$}

A edificação destinada ao Refeitório deverá ter as seguintes características:

Esta edificação deverá ter capacidade para atender 300 alunos por turno de refeição e será composta apenas por um pavimento em estrutura pré-fabricada, contendo rede de glp, ventilação cruzada e previsão de ar condicionado. Esta edificação receberá instalações específicas para cozinha industrial e seu projeto deverá ser acompanhado por profissional especializado. Deverá ser previsto uma central de aquecimento de água por energia solar. O programa básico para este projeto pede:

- salão para restaurante para 300 pessoas;

- área para distribuição;

- área para retorno e higienização de utensílios;

- cozinha industrial;

- despensa;

- administração;

- área para recebimento de produtos;

- sanitários / vestiários (masculino e feminino);

- espaço de funcionários, vestiários (masculino e feminino) - prever uso energia solar;

- área para saída de lixo.

\section{Bloco 06 - Laboratórios de Pesquisa em Engenharia e Docentes $-4.200 \mathrm{~m}^{2}$}

Este bloco deverá atender ao corpo docente das engenharias e suas necessidades de pesquisas. Os laboratórios previstos neste bloco são aqueles que exigem instrumentos e instalações de maior porte, do tipo industrial, que requerem grandes quantidades de insumos, que necessitam de áreas isoladas para evitar contaminação e áreas abertas ao sol. Como exemplos, podemos citar laboratórios de integridade estrutural, de instalações de geração e conversão de energia, de materiais, de biologia, etc. Para tanto o programa básico pede:

- prever salas individuais para 100 professores;

- prever cerca de $2800 \mathrm{~m}^{2}$ de unidades de laboratório;

- prever cerva de $650 \mathrm{~m} 2$ de unidades de laboratório de maior porte;

- salas para defesa de tese;

- salas de reuniões;

- copa;

- depósitos;

- sala de telecom nos pavimentos;

- cafeteria;

- sanitários (masculino e feminino);

- circulação horizontal e vertical;

- toda a laje do pavimento térreo terá, obrigatoriamente, isolamento vibracional modulado de acordo com os ambientes;

- prever grupo gerador, em sala com isolamento acústico, compatível com a carga instalada;

- prever ar condicionado para todos os ambientes de permanência prolongada;

- prever instalações de gás, instalações para gases especiais, ar comprimido;

- linha de sistemas de exaustão independente;

- telecom - salas de apoio para rede de lógica/elétrica.

Como orientação geral, sugere-se que as salas de professores e as salas de laboratórios sejam separadas por um corredor de forma que os professores possam estar sempre próximos de seus laboratórios. Deve-se imaginar que, na maioria dos casos, grupos de 2 a 5 professores utilizem o mesmo laboratório podendo entretanto existir laboratórios sob responsabilidade de apenas um 


\section{$\frac{1}{2}$ \\ MINISTÉRIO DA EDUCAÇÃO \\ FUNDAÇÃO UNIVERSIDADE FEDERAL DO ABC \\ PRÓ-REITORIA DE ADMINISTRAÇÃO \\ COMISSÃO ESPECIAL DE LICITAÇÃO}

Processo $n^{\circ} .23006 .000232 / 2008-79$

professor. Devem-se prever algumas salas maiores e de pé direito duplo para acomodar instalações laboratoriais de porte industrial.

Contíguo ao Bloco 6 deve ser previsto uma área de $2500 \mathrm{~m}^{2}$ gramada para acomodar instalações ao ar livre como painéis solares, geradores eólicos, etc.

De modo geral, as salas devem ser ventiladas e ter iluminação natural. As divisórias devem ser feitas de paredes leves, facilmente removíveis, de forma que as salas laboratoriais constituam-se em módulos que possam ser agrupados em salas maiores.

Obs.: detalhamento do tipo de equipamentos e infra-estrutura gerais destes laboratórios serão dados pela equipe técnica da UFABC durante a fase de Estudo Preliminar

\section{Bloco 07 - Laboratórios de Pesquisa em Ciências da Cognicão e Sistemas Complexos -}

$\underline{4.200 \mathrm{~m}^{2}}$.

A edificação destinada a Pesquisa / Cognição deverá ter as seguintes características:

Esta edificação deverá ter capacidade para atender os professores e deverá ser composta por pavimentos em estrutura pré-fabricada de concreto ou convencional, sombreamento de fachadas, ventilação cruzada e previsão de ar condicionado para todos os ambientes.

O programa básico para projeto destes pavimentos pede:

- toda a laje do pavimento térreo terá, obrigatoriamente, isolamento vibracional modulado de acordo com os ambientes;

- prever $1.000 \mathrm{~m}^{2}$ de laboratórios com capelas;

- prever grupo gerador, em sala com isolamento acústico, compatível com a carga instalada;

- prever ar condicionado para todos os ambientes de permanencia prolongada;

- salas individuais para 100 professores;

- salas para defesa de tese;

- salas de reuniões;

- laboratórios de pesquisa em planta livre;

- copa;

- depósitos;

- telecom - salas de apoio para rede de lógica/elétrica.

- cafeteria;

- sanitários (masculino e feminino);

- circulação horizontal e vertical;

- prever instalações de gás, instalações para gases especiais, ar comprimido;

- linha de capelas com sistema de exaustão independente;

- este edifício poderá ser distinto dos demais edifícios no que diz respeito ao número de pavimentos e demais especificidades.

Prever um Biotério com área aproximada de $300 \mathrm{~m}^{2}$. Esta edificação deverá ser implantada entre o Bloco 6 - Pesquisa em Engenharia e Docentes e o Bloco 7 - Pesquisa em Ciências da Cognição e Sistemas Complexos, de forma a atender os docentes pesquisadores. Esta área deverá ser subtraída da área total deste 2 (dois) blocos.

Obs:: detalhamento do tipo de equipamentos e infra-estrutura gerais destes laboratórios serão dados pela equipe técnica da UFABC durante a fase de Estudo Preliminar 


\section{MINISTÉRIO DA EDUCAÇÃO \\ FUNDAÇÃO UNIVERSIDADE FEDERAL DO ABC \\ PRÓ-REITORIA DE ADMINISTRAÇÃO \\ COMISSÃO ESPECIAL DE LICITAÇÃO}

Processo $n^{\circ} .23006 .000232 / 2008-79$

\section{Bloco 08 - Laboratórios de Computacão Científica e de Alto Desempenho - 1000m²}

A edificação destinada a laboratórios de Computação Científica e de Alto Desempenho, deverá ter as seguintes características:

Esta edificação deverá ter capacidade para atender os pesquisadores e pessoal técnico administrativo com ventilação cruzada e previsão de ar condicionado para todos os ambientes.

O programa básico para projeto destes pavimentos pede

- toda a laje do pavimento térreo terá, obrigatoriamente, isolamento vibracional modulado de acordo com os ambientes;

- prever Datacenter de aproximadamente $300 \mathrm{~m}^{2}$ conforme características definidas no item 2.8.2.2 deste anexo;

- prever sala de operações e controle para o Datacenter com acesso restrito;

- prever grupo gerador, em sala com isolamento acústico, compatível com a carga instalada;

- salas individuais para 40 professores;

- prever ar condicionado para todos os ambientes de permanencia prolongada;

- salas de reuniões;

- laboratórios de pesquisa em planta livre, com respectiva sala de coordenação;

- copa;

- depósitos;

- telecom - salas de apoio para rede de lógica/elétrica.

- sanitários (masculino e feminino);

- circulação horizontal e vertical;

- este edifício poderá ser distinto dos demais edifícios no que diz respeito ao número de pavimentos e demais especificidades.

Obs.: detalhamento do tipo de equipamentos e infra-estrutura gerais destes laboratórios serão dados pela equipe técnica da UFABC durante a fase de Estudo Preliminar

\section{Bloco 09 - Administracão $-1.000 \mathrm{~m}^{2}$}

A edificação destinada à Administração deverá ter as seguintes características:

Esta edificação deverá atender todos os funcionários administrativos e de apoio à universidade e ser composto por pavimentos em estrutura pré-fabricada de concreto, com previsão de ar condicionado para todos os ambientes. Este edifício poderá ser distinto dos demais edifícios constantes da $1^{\text {a }}$ fase de obras no que diz respeito ao número de pavimentos e demais especificidades.

O programa básico para este projeto pede

- ambientes com estações de trabalho dispostas em planta livre para trabalho técnicoadministrativo;

- sala de espera;

- salas individuais;

- salas de reunião;

- secretaria com atendimento a alunos;

- telecom - salas de apoio para rede de lógica/elétrica.

- sanitários;

- copa;

- depósito material de limpeza;

- circulação horizontal e vertical. 


\section{MINISTÉRIO DA EDUCAÇÃO \\ FUNDAÇÃO UNIVERSIDADE FEDERAL DO ABC \\ PRÓ-REITORIA DE ADMINISTRAÇÃO \\ COMISSÃO ESPECIAL DE LICITAÇÃO}

Processo $n^{\circ} .23006 .000232 / 2008-79$

\section{Bloco 10 - Espaco de Recreacão - 400m²}

A edificação destinada Espaço de Recreação deverá ter as seguintes características:

- sala para jogos;

- salas de práticas esportivas

- sanitários (masculino e feminino);

- vestiários (masculino e feminino) - prever uso energia solar;

- depósito para material desportivo;

\section{Bloco da Portaria Principal $-100 \mathrm{~m}^{2}$}

A edificação destinada à Portaria Principal deverá ter as seguintes características:

- guarita para controle de acessos;

- prever sala de supervisão, comando e controle de todas as edificações;

- sanitários (masculino e feminino);

- vestiários (masculino e feminino) - prever uso de energia solar;

- espaços para empresas terceirizadas;

- copa;

- depósitos para empresas terceirizadas.

Considerar portarias de menor porte nos acessos secundários e/ou de veículos.

\subsection{QUADRO RESUMO DAS ÁREAS}

\begin{tabular}{|l|r|l|}
\hline \multicolumn{3}{|c|}{ RESUMO DAS ÁREAS } \\
\hline BLOCO 1 - ENSINO & $2.800,00$ & $\mathrm{~m}^{2}$ \\
\hline BLOCO 2 - LABORATÓRIOS DIDATICOS & $2.800,00$ & $\mathrm{~m}^{2}$ \\
\hline BLOCO 3 - BIBLIOTECA/SALAS DE ESTUDOS & $1.500,00$ & $\mathrm{~m}^{2}$ \\
\hline BLOCO 4 - ANFITEATROS & $1.200,00$ & $\mathrm{~m}^{2}$ \\
\hline BLOCO 5 - REFEITÓRIO & 800,00 & $\mathrm{~m}^{2}$ \\
\hline BLOCO 6 - LABORATÓRIOS DE PESQUISA EM ENGENHARIA E DOCENTES & $4.200,00$ & $\mathrm{~m}^{2}$ \\
\hline $\begin{array}{l}\text { BLOCO 7 - LABORATÓRIOS DE PESQUISA EM CIÊNCIAS DA COGNIÇÃO E } \\
\text { SISTEMAS COMPLEXOS }\end{array}$ & $4.200,00$ & $\mathrm{~m}^{2}$ \\
\hline BLOCO 8 - COMPUTAÇÃO CIENTÍFICA E DE ALTO DESEMPENHO & $1.000,00$ & $\mathrm{~m}^{2}$ \\
\hline BLOCO 9 - ADMINISTRAÇÃO & $1.000,00$ & $\mathrm{~m}^{2}$ \\
\hline BLOCO 10 - APOIO ESPORTIVO/ PORTARIAS & 400,00 & $\mathrm{~m}^{2}$ \\
\hline BLOCO PORTARIA PRINCIPAL & 100,00 & $\mathrm{~m}^{2}$ \\
\hline ÁREA TOTAL CONSTRUÍDA & $20.000,00 \mathrm{~m}^{2}$ \\
\hline
\end{tabular}

\subsection{DIRETRIZES PARA PROJETOS COMPLEMENTARES}

A configuração das instalações (energia, fluidos, comunicação, lógica) deve priorizar a racionalidade e a economia de manutenção das respectivas redes, sejam internas ou externas. 


\section{손 \\ MINISTÉRIO DA EDUCAÇÃO \\ FUNDAÇÃO UNIVERSIDADE FEDERAL DO ABC \\ PRÓ-REITORIA DE ADMINISTRAÇÃO \\ COMISSÃO ESPECIAL DE LICITAÇÃO}

Processo $n^{\circ} .23006 .000232 / 2008-79$

\subsubsection{Instalações Elétricas}

A concepção do projeto de instalações elétricas deverá resultar da comparação entre as diversas soluções alternativas, selecionando-se a mais adequada, considerando-se os parâmetros técnicos, econômicos e ambientais. A solução deverá estar em harmonia com os Projetos de Arquitetura, Estrutura e demais instalações, observando a não interferência entre os elementos dos diversos sistemas da edificação.

Entrada e Medição de Energia Elétrica - O fornecimento de energia elétrica poderá ser em média tensão (aproximadamente $15 \mathrm{kV}$ ), com potencia nominal compatível com a carga instalada (aproximadamente 2,5 MVA ou $2.500 \mathrm{kVA}$ )

Tensão de Distribuição - A tensão secundaria de distribuição de energia elétrica será trifásica, $220 / 127 \mathrm{~V}-60 \mathrm{~Hz}$ para iluminação, tomadas e equipamentos em todos os edifícios e em todo o Campus.

\subsubsection{Projeto de Telefonia, Rede Estruturada de Comunicação de Dados e Data Center}

\subsubsection{Telefonia}

Apresentando o detalhamento das soluções de instalação, conexão e fixação de todos os componentes do sistema de telefonia a ser implantado, incluindo os embutidos e rasgos a serem previstos na estrutura da edificação; contendo projeto de tubulações e projeto de redes de cabos e fios, plantas com a locação definitiva das caixas, prumadas de toda a rede de tubulação secundária e de entrada, detalhes gerais da caixa subterrânea de entrada ou entrada aérea, cubículos de distribuição; arranjo da central privada de comutação telefônica e relatório técnico.

\subsubsection{Cabeamento Estruturado e Data Center}

Apresentando o detalhamento das soluções de instalação conexão e fixação de todos os componentes do sistema a ser implantado, incluindo os embutidos e rasgos a serem previstos na estrutura da edificação; com plantas gerais indicando caminhamentos dos cabos de interligação e respectivas identificações; desenhos esquemáticos de interligação; diagrama de blocos; detalhamento da instalação dos painéis, equipamentos e da infra-estrutura; identificação das tubulações e circuitos adotando critérios uniformes e seqüência lógica; detalhes do sistema de aterramento; legendas das convenções utilizadas; lista detalhada de equipamentos e materiais da instalação e respectivas garantias; detalhes de todos os furos necessários nos elementos estruturais e de todas as peças a serem embutidas ou fixadas nas estruturas de concreto ou metálicas, para passagem ou suporte da instalação; relatório técnico.

Além das linhas gerais detalhadas anteriormente, os projetos, básico e executivo, de cabeamento estruturado para o Campus de São Bernardo do Campo, deverão contemplar, no mínimo, os seguintes requisitos:

- Infra-estrutura, como calhas, esteiras e eletrodutos de ferro galvanizado, de bitola adequada, tipo leve e suas respectivas conexões, para o roteamento do cabeamento de telecomunicações (Vertical e Horizontal), devendo ser previsto no mínimo $60 \%$ de folga na tubulação após a passagem dos cabos previstos no projeto;

- Toda a solução de cabeamento estruturado deve estar compatível com as normas TIA/EIA568A, TIA/EIA-569, ISO/IEC-11801;

- As instalações devem ser aterradas seguindo a norma EIA/TIA 607; 


\section{돈 \\ MINISTÉRIO DA EDUCAÇÃO \\ FUNDAÇÃO UNIVERSIDADE FEDERAL DO ABC \\ PRÓ-REITORIA DE ADMINISTRAÇÃO \\ COMISSÃO ESPECIAL DE LICITAÇÃO}

Processo n. 23006.000232/2008-79

- Previsão de salas de telecom nos edifícios de acordo com as normas TIA/EIA-568A, TIA/EIA569, ISO/IEC-11801, ANSI/EIA/TIA-942;

- Contemplar Datacenter - alocado no Bloco 8 composto por dois ambientes, sendo o primeiro com capacidade para instalação de aproximadamente 50 racks (Pesquisa), e o segundo com capacidade para instalação de aproximadamente 10 racks (Telecom). A solução deverá contemplar os seguintes itens de infra-estrutura:

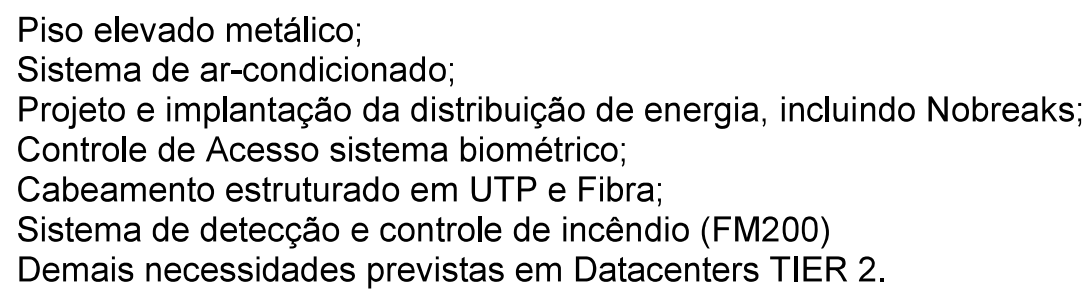

- O Datacenter concentrará toda operação, controle e gerenciamento da infra-estrutura de telefonia, redes e serviços do Campus e deverá estar de acordo com a norma ANSI/EIA/TIA-942, seguindo, também, os padrões das normas ANSI/EIA/TIA-942, ISSO/IEC-11801, TIA/EIA-569, TIA/EIA-568A, TIA/EIA-607, TIA/EIA-606;

- Piso elevado nas salas de telecom em cada pavimento do objeto deste projeto.

- Utilização de cabo UTP - CAT6, ou superior da época, de acordo com as normas técnicas internacionais (ANSI/EIA/TIA) e nacionais ABNT para todo o cabeamento horizontal, prevendo utilização de rede de dados de acordo com a norma IEEE 802.3ab;

- Utilização de cabo de fibra óptica para o cabeamento vertical dos edifícios do campus prevendo utilização de rede de dados de acordo com a norma 802.3ae (10gb ethernet sobre fibra);

- Instalação do cabeamento entre os edifícios do campus, prevendo duplo anel óptico e redundância em par metálico de acordo com normas 802 .3ae(10Gb ethernet sobre fibra) e 802.3an(10Gb ethernet sobre par metálico;

- Prever acesso a rede sem fio para todo o campus de acordo com as normas $802.11 \mathrm{a} / \mathrm{b} / \mathrm{g} / \mathrm{n}$; Rede sem fio outdoor e indoor;

- Estão excluídos deste projeto equipamentos ativos de rede (Switches, Roteadores, Firewalls e etc.);

- Do número e distribuição de pontos de acesso: Projeto básico de no mínimo 2.500 (dois mil e quinhentos) pontos de acesso adequadamente distribuídos de acordo com ocupação definida no projeto arquitetônico/civil e devida infra-estrutura solicitada.

\subsubsection{Sonorização, Projeção, Antena Coletiva e TV a Cabo}

Toda sala de aula (anfiteatros, inclusive) com capacidade para mais de 60 alunos deverá ter sistema de sonorização.

Toda sala de aula (anfiteatros, inclusive) e laboratórios didáticos deverá ter projetor multimídia (acoplado ao teto) e tela de projeção. Para isto deverá ser previsto infra-estrutura elétrica e de calhas para lance de cabo de conexão projetor e mesa do professor. 


\section{(1) \\ $1 . *+$ \\ 2 \\ MINISTÉRIO DA EDUCAÇÃO \\ FUNDAÇÃO UNIVERSIDADE FEDERAL DO ABC \\ PRÓ-REITORIA DE ADMINISTRAÇÃO \\ COMISSÃO ESPECIAL DE LICITAÇÃO}

Processo $n^{\circ}$. 23006.000232/2008-79

Todos os edifícios voltadas para pratica de ensino e pesquisa receberão Antena Coletiva e TV a Cabo, inclusive o Bloco 9 - Administrativo.

\subsubsection{Projeto de Detecção e Combate de Incêndio}

A concepção do Sistema de Detecção e Prevenção e Combate à Incêndio deverá resultar da comparação entre as diversas soluções a Iternativas, selecionando-se a mais adequada, considerando-se os parâmetros técnicos, econômicos e ambientais.

Deverá ter aprovação junto ao Corpo de Bombeiros do Estado de São Paulo de acordo com o Decreto Estadual $n^{\circ} 46.076 / 01$.

A solução deverá estar em harmonia com os Projetos de Arquitetura, Estrutura e demais instalações, observando a não interferência entre os elementos dos diversos projetos e a necessidade de acesso para inspeção e manutenção das instalações.

Deverá incluir um Projeto de Iluminação de Emergência com Rotas de Fuga, que contemplará um sistema de sinalização para rota de fuga que vise à proteção da população dos edificios, através de luminárias de balizamento, com indicações de seta, distribuídas de forma a permitir fácil visualização de quaisquer pontos das áreas comuns, corredores, recepção, halls, estacionamentos, caixas de escadas, etc.

As luminárias de balizamento deverão estar conectadas a circuitos normais de alimentação, serem autônomas e possuir fonte de energia própria. INMETRO:

A elaboração do projeto deverá atender também às seguintes Normas da ABNT e

a) NBR 944 itens 5.2.4, 5.3.3 e Anexo C;

b) NBR 9441 - Execução de Sistemas de Alarme e Detecção de Incêndio;

c) NBR - 10898/90;

Normas regulamentadoras do Capítulo V, Título II, da CLT:

a) NR 26 - Sinalização de Segurança;

b) NR 23 - Proteção contra Incêndios;

Normas e diretrizes de Projeto do Corpo de Bombeiros Local;

Normas Estrangeiras: "National Fire Protection Association (NFPA) - 70.1 / 72A / 72B / 72C / 72D /

$72 \mathrm{E} / 74$ / 101

\subsubsection{Instalações de Supervisão Predial}

A concepção do Sistema de Supervisão, Comando e Controle deverá resultar da comparação entre as diversas soluções alternativas, selecionando-se a mais adequada, considerando-se os parâmetros técnicos e econômicos.

A solução deverá estar em harmonia com os Projetos de Arquitetura, Estrutura e demais instalações, observando a não interferência entre os elementos dos diversos sistemas da edificação.

O sistema SCCE deverá executar o gerenciamento das instalações a seguir:

- ar condicionado;

- $\quad$ iluminação interna e externa;

- elevador;

- bombas;

- reservatórios;

- segurança:

- $\quad$ detecção e alarme de incêndio; 


\section{솔 \\ MINISTÉRIO DA EDUCAÇÃO \\ FUNDAÇÃO UNIVERSIDADE FEDERAL DO ABC \\ PRÓ-REITORIA DE ADMINISTRAÇÃO \\ COMISSÃO ESPECIAL DE LICITAÇÃO}

Processo $n^{\circ}$. 23006.000232/2008-79

- $\quad$ controle de acesso;

- $\quad$ circuito fechado de TV.

Deverá ser prevista ainda uma estação repetidora na portaria principal ou outro local definido pelo projeto arquitetônico.

\subsubsection{Instalações Hidráulicas e Sanitárias}

A concepção do projeto de instalações hidro-sanitárias deverá resultar da comparação entre as diversas soluções alternativas, selecionando-se a mais adequada, considerando-se os parâmetros técnicos, econômicos e ambientais. A solução deverá estar em harmonia com os Projetos de Arquitetura, Estrutura e demais instalações, observando a não interferência entre os elementos dos diversos sistemas da edificação.

- Prever sistemas de reuso de água irrigação de jardins, limpeza, bacias sanitárias, refrigeração, sistema de combate a incêndio e demais usos permitidos para água não potável;

- Prever tanques de retenção de águas pluviais e/ou sistemas de percolação destas, conforme Lei Estadual 12.526/1007;

- Prever sistemas de aquecimento solar de água atendendo a vestiários, cozinhas e outros usos definidos pelo projeto arquitetônico;

- Prever tratamento de águas servidas (efluentes) de todos laboratórios didáticos e de pesquisa, cuja vazão deverá ser definida na elaboração dos projetos;

\subsubsection{Instalações contra Descargas Atmosféricas}

A proteção contra descargas atmosféricas deverá ser efetuada através de captores atmosféricos constituídos de cabos de cobre nu e ferragens da estrutura com continuidade elétrica garantida. O sistema de pára-raios será interligado à malha de aterramento de segurança dos edifícios.

É imperativo o adequado dimensionamento dos pára-raios e aterramentos nos blocos dos laboratórios didáticos e de pesquisa, de forma a evitar ruídos nas medições de precisão desenvolvidas em tais ambientes.

O Projeto do Sistema de Proteção contra Descargas Atmosféricas deverá seguir as recomendações da norma ABNT, além da NBR - 5419.

\subsection{LEGISLAÇÕES E NORMAS TÉCNICAS}

O projeto deverá atender as leis, decretos, resoluções, normas e outros dispositivos estabelecidos na legislação vigente nos âmbitos federal, estadual e municipal. A seguinte lista é apenas indicativa dos dispositivos diretamente concernentes ao Objeto do presente Edital, pois são presumidos, por parte dos proponentes, o perfeito conhecimento e a obediência à legislação em geral.

\section{Legislação Federal}

- Todos os Projetos deverão ser elaborados em obediência às diretrizes gerais da Lei $\mathrm{n}^{0}$. 8.666/93 de 21/06/1993;

- $\quad$ Lei $N^{\circ} 4.771$, de 15 de setembro de 1965 - Institui o Novo Código Florestal;

- $\quad$ Lei $N^{\circ} 7.803$, de 15 de agosto de 1989 - Altera o Código Florestal (Altera a redação da Lei $\mathrm{N}^{\circ} 4.771$, de 15 de setembro de 1965, e revoga as Leis $\mathrm{N}^{\circ} 6.535$, de 15 de julho de 1978 e 7.511, de 7 de julho de 1986); 


\section{(1) \\ MINISTÉRIO DA EDUCAÇÃO \\ FUNDAÇÃO UNIVERSIDADE FEDERAL DO ABC \\ PRÓ-REITORIA DE ADMINISTRAÇÃO \\ COMISSÃO ESPECIAL DE LICITAÇÃO}

Processo $n^{\circ} .23006 .000232 / 2008-79$

- $\quad$ Decreto $N^{\circ} 750$, de 10 de fevereiro de 1993 - Dispõe sobre o corte, a exploração e a supressão de vegetação primária ou nos estágios avançado e médio de regeneração da Mata Atlântica, e dá outras providências;

- $\quad$ Decreto № 5.296 de 2 de dezembro de 2004. Regulamenta as Leis № 10.048, de 8 de novembro de 2000, que dá prioridade de atendimento às pessoas que especifica, e $\mathrm{N}^{0} 10.098$, de 19 de dezembro de 2000, que estabelece normas gerais e critérios básicos para a promoção da acessibilidade das pessoas portadoras de deficiência ou com mobilidade reduzida, e dá outras providências.

\section{Legislação Estadual}

Leis estaduais de SP mais relevantes para os objetivos técnicos iniciais deste Edital

- Lei $N^{\circ} 898$, de $1^{\circ}$ de novembro de 1975 (Já alterada pela Lei Estadual n 3.746/83) Disciplina o uso do solo para a proteção dos mananciais, cursos e reservatórios de água e demais recursos hídricos de interesse da Região Metropolitana da Grande São Paulo, em cumprimento ao disposto nos Incisos II e III do art. $2^{\circ}$ e Inciso VIII do art. $3^{\circ}$ da Lei Complementar 94, de 29 de maio de 1974;

- Lei $N^{\circ} 1.172$, de 17 de novembro de 1976 - Delimita as áreas de proteção relativas aos mananciais, cursos e reservatórios de água, a que se refere o artigo $2^{\circ}$ da Lei $n^{\circ} 898$, de 18 de dezembro de 1975, estabelece normas de restrição de uso do solo em tais áreas e dá providências correlatas;

- Lei $N^{0} 11.216$, de 22 de julho de 2002 - Altera a lei $\mathrm{N}^{0} 1.172$ de 17 de novembro de 1976, que delimita as áreas de proteção dos mananciais, cursos e reservatórios de água de interesse da Região Metropolitana da Grande São Paulo.

\section{Legislação Municipal}

Conforme Anexo $\mathrm{V}$ deste edital.

\section{Normas Técnicas Brasileiras e Normas Regulamentadoras}

As seguintes são relevantes para os objetivos técnicos iniciais deste Edital, pois poderão representar um forte condicionante para a concepção do partido geral (corredores, escadas, rampas, elevadores, sanitários, vestiários etc.):

1.1. Práticas de Projeto, Construção e Manutenção de Edifícios Públicos e Federais;

1.2. Normas da ABNT e do INMETRO (pertinentes a cada assunto);

1.3. NBR - 9050 - Acessibilidade de pessoas portadoras de deficiências às edificações, espaço, mobiliário e equipamento urbano;

1.4. NR 24 - Das Condições Sanitárias e de Conforto nos Locais de Trabalho, da Secretaria de Segurança e Saúde no Trabalho;

1.5. Instruções e Resoluções dos Órgãos do Sistema CREA-CONFEA;

1.6. NBR 13994 - Elevadores de Passageiros - Elevadores para Transportes de Pessoa Portadora de Deficiência;

1.7. NBR 14718 - Guarda-corpos para edificação.

A presença de laboratórios exige a obediência a normas ambientais e de segurança do trabalho, não só as relacionadas com os usuários e suas atividades, mas também quanto à coleta, ao acondicionamento e ao afastamento dos resíduos químicos e biológicos perigosos. 


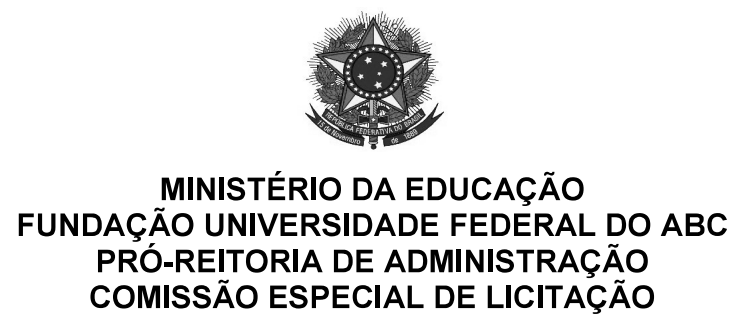

Processo n ${ }^{\circ} .23006 .000232 / 2008-79$

\subsection{RELATÓRIO FOTOGRÁFICO}

Foto aérea do terreno

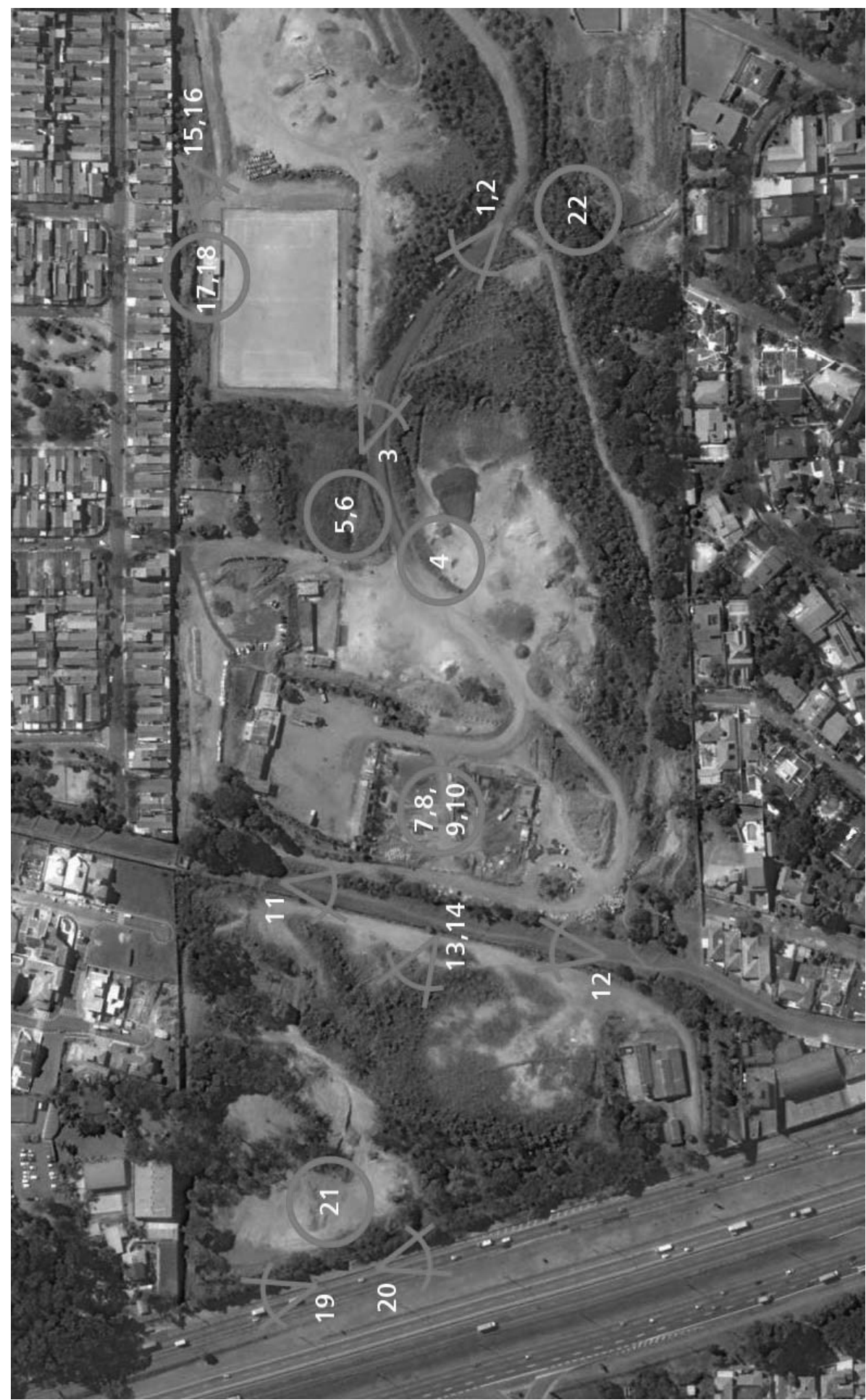




\section{슬 \\ MINISTÉRIO DA EDUCAÇÃO \\ FUNDAÇÃO UNIVERSIDADE FEDERAL DO ABC \\ PRÓ-REITORIA DE ADMINISTRAÇÃO \\ COMISSÃO ESPECIAL DE LICITAÇÃO}

Processo n. 23006.000232/2008-79

\section{ANEXO II \\ PLANO DE TRABALHO E DESCRIÇÃO DOS SERVIÇOS}

\section{INTRODUÇÃO}

Este Anexo tem por finalidade definir o escopo dos serviços a serem entregues desde a elaboração de estudo preliminar, projetos básicos e projetos executivos de urbanismo, arquitetura, projetos complementares e projetos legais necessários a IMPLANTAÇÃO DO CAMPUS DA UNIVERSIDADE FEDERAL DO ABC EM SÃO BERNARDO DO CAMPOISP.

O autor do Projeto deverá considerar, para casos específicos, a prescrição mais exigente, quer na esfera Municipal, Estadual ou Federal.

\section{Serviços Preliminares:}

1.1. Relatório de Vistoria - A vistoria do local deverá ser executada por todos os projetistas das áreas técnicas envolvidas no projeto. Serão verificados os fluxos mais evidentes de circulação de pedestres, veículos e transporte publico para melhor compreensão da área. Conferir junto ao levantamento planialtimétrico e indicar a existência e localização de edificações e córregos; dos serviços concessionários de água e esgoto, energia - baixa e alta tensão, gás, telefone, iluminação pública, recolhimento de lixo, pavimentação, guias e calçadas. A consulta prévia aos órgãos concessionários complementará as informações. Como produto da etapa, será entregue à UFABC duas cópias impressas do Relatório de Vistoria com, no mínimo, 16 fotos, devidamente assinadas pelos seus responsáveis, bem como, todo o material/mídias em meio digital (arquivos, CDs...). Indicar em croqui a posição de tomada das fotos numerando e legendando a identificação.

1.2. Consulta aos órgãos competentes - esta consulta tem como objetivo a apresentar o estudo de viabilidade aos órgãos e concessionárias para garantir a viabilidade das soluções propostas e permitir a continuidade dos trabalhos

1.3. Sondagem geológica do terreno - A UFABC fornecerá oportunamente, quando da contratação da empresa vencedora do Certame, o Relatório de Sondagem, que está em execução - prevista para 20 furos de $15 \mathrm{~m}$, em média, distribuídos em toda a extensão do terreno. Qualquer outra sondagem complementar ocorrerá por conta do licitante vencedor e deverão atingir profundidades necessárias à solução dos problemas de fundações e serem executadas segundo as normas da ABNT.

1.4. Levantamento planialtimétrico e cadastral - conforme solicitação da UFABC, levantamento complementar ao fornecido pela UFABC, em área de, aproximadamente, $2.000 \mathrm{~m}^{2}$ para a implantação da futura passarela para pedestres por sobre a Via Anchieta.

1.5. Estudos preliminares - verificará a adequação do projeto em relação às principais diretrizes estabelecidas pela UFABC. Será analisada a implantação, considerando-se inclusive futuras ampliações; inter-relacionamento das edificações, a adoção do partido arquitetônico, assegurando a viabilidade técnica e econômica, impedindo a adoção de partidos arquitetônicos e/ou uso de materiais que impliquem obras de custos elevados; principais elementos que caracterizam as edificações; insolação dos ambientes, etc. Nesta etapa de projeto será de fundamental importância a verificação e organização preliminar dos traçados de redes (internas e externas) de elétricas, lógicas, esgoto, água limpa, água pluvial, água de reuso, gás e sistema de condicionamento de ar . Como produto, serão entregues os Estudos Preliminares de 


\section{(1) \\ MINISTÉRIO DA EDUCAÇÃO \\ FUNDAÇÃO UNIVERSIDADE FEDERAL DO ABC \\ PRÓ-REITORIA DE ADMINISTRAÇÃO \\ COMISSÃO ESPECIAL DE LICITAÇÃO}

Processo $n^{\circ} .23006 .000232 / 2008-79$

todas as áreas envolvidas no projeto. Os relatórios referentes aos estudos preliminares deverão conter:

1.5.1. síntese dos levantamentos da micro-bacia hidrográfica e das condições encontradas no entorno da gleba total, com a indicação das diretrizes a serem consideradas no projeto urbanístico face a essas informações;

1.5.2. avaliação dos condicionantes do meio físico e biótico da gleba, com a indicação dos terrenos com impedimentos ou limitações para a ocupação face a esses condicionantes. O documento síntese dessa avaliação deve apresentar o relato das visitas e investigações de campo conduzidas para elaboração do diagnóstico;

1.5.3. levantamento dos condicionantes para implantação das obras de transporte, circulação viária, fornecimento de energia, telefonia, abastecimento de água água de reuso, manejo e disposição de efluentes, manejo e disposição de resíduos, manejo de águas pluviais e demais serviços de infra-estrutura;

1.5.4.síntese das limitações legais e diretrizes dos órgãos públicos e concessionárias de serviços públicos, para implantação das obras:

1.5.5. prognóstico das obras e intervenções previstas no entorno da gleba e dos impactos associados a essas intervenções.

1.5.6. mapa síntese do diagnóstico e prognóstico da área com indicações dos setores potencialmente mais favoráveis para os diversos usos previstos;

1.5.7.três diferentes propostas de urbanização da área, com as respectivas propostas de uso e ocupação do solo, plano de massa das edificações, identificação do setor destinado à primeira etapa das obras (correspondente a cerca de $20 \%$ do total da gleba) e propostas para equacionamento das obras de infra-estrutura. Além das plantas e mapas deverá ser apresentado, para cada uma dessas alternativas, uma maquete eletrônica e documento síntese contendo a análise dos aspectos positivos e dificuldades associadas a cada proposta, incluindo indicadores das obras e de custos. Esse documento deverá conter ainda uma avaliação preliminar dos possíveis impactos decorrentes da obra, na fase final e na primeira etapa, com a indicação de medidas de prevenção, mitigação e compensação desses impactos.

1.6. Estudo de Impacto de Vizinhança - EIV - conforme art. 13 da LM 5714/2007 e art 29 da LM 5716/2007. Trata-se do conjunto de estudos e informações técnicas relativas à identificação, avaliação, prevenção, mitigação e compensação dos impactos na vizinhança, de forma a permitir a avaliação das diferenças entre as condições existentes e as que existirão com a implantação da mesma. Todas as orientações resultantes do EIV deverão ser contempladas no projeto de implantação da UFABC.

\section{Projeto Básico}

O Projeto Básico será desenvolvido a partir da aprovação do Estudo Preliminar e deverá ser 0 mais detalhado possível, contendo todas as informações necessárias à perfeita execução e levantamento de custos da obra. Restarão para o Projeto Executivo, tão somente os detalhamentos que não dêem margem a alteração do custo final da obras. 


\section{MINISTÉRIO DA EDUCAÇÃO \\ FUNDAÇÃO UNIVERSIDADE FEDERAL DO ABC \\ PRÓ-REITORIA DE ADMINISTRAÇÃO \\ COMISSÃO ESPECIAL DE LICITAÇÃO}

Processo $n^{\circ} .23006 .000232 / 2008-79$

Objetiva a efetivação das consultas prévias aos órgãos públicos e concessionárias interferentes e a compatibilização inicial das várias disciplinas que compõem o projeto (arquitetura, instalações, sistema de ar condicionado ventilação e exaustão, redes elétricas, de água e esgoto, lógica, cálculo estrutural, dentre outras). Deve caracterizar em sua totalidade o objeto a ser licitado, com a finalidade de minimizar a necessidade de sua reformulação ou de variantes durante as fases de elaboração do projeto executivo e de realização das obras.

A orçamentação do custo global da construção fundamentar-se-á em quantitativos de materiais, serviços e fornecimentos apropriadamente avaliados. Os preços dos serviços deverão ser obtidos a partir de planilhas oficiais - SINAPI - ou privados com reconhecida aceitação no mercado;

O conjunto dos projetos básicos será apresentado em arquivos com extensão dwg (AutoCAD), plt (Plotter) e pdf (Adobe Acrobat). Planilhas e textos de extensão .doc (Word), .xls (Excel) serão gravados em compact disk, não-regravável, e em 02 (duas) cópias impressas nas escalas previstas em normas técnicas.

O projeto básico será composto pelos seguintes produtos (Anexo VII):

Memoriais descritivos dos projetos justificando a proposta arquitetônica adotada e os materiais a serem utilizados;

Pareceres dos Consultores;

Relatório técnico e memorial justificativo e de cálculos para cada projeto complementar;

Caderno de encargos contendo as especificações de materiais e serviços;

Orçamento detalhado do custo global da obra;

Parecer de Fundações

Maquete de apresentação em escala a ser definida pela UFABC;

Desenhos:

2.1. Urbanismo (para toda a extensão da gleba):

Projeto de Implantação

Projeto de Terraplenagem

Projeto de Sistema Viário e Geométrico

Projeto de Paisagismo

Projeto de Infra-estrutura

\subsection{Arquitetura}

Projetos das edificações - plantas, cortes, fachadas, layout e detalhamento.

Projeto de Comunicação Visual

Projeto de Luminotecnia

2.3. Fundações e Estrutura

Projeto de Fundações;

Projeto de Estrutura de Concreto;

Projeto de Estrutura Metálica.

\subsection{Elétrica}

Projeto de Instalações Elétricas, energia solar e fotovoltaica.

Projeto de Sonorização e TV a Cabo;

Projeto de Circuito fechado de TV;

Projeto de Detecção e Alarme de Incêndio;

Projeto de Rede de Comunicação de Dados e Telefonia (Cabeamento Estruturado);

Projeto de Supervisão, Comando e Controle de Edificações:

Projeto de Proteção contra Descarga Atmosférica; 


\section{MINISTÉRIO DA EDUCAÇÃO \\ FUNDAÇÃO UNIVERSIDADE FEDERAL DO ABC \\ PRÓ-REITORIA DE ADMINISTRAÇÃO \\ COMISSÃO ESPECIAL DE LICITAÇÃO}

Processo $n^{\circ}$. 23006.000232/2008-79

\subsection{Hidráulica}

Projeto de Água Fria;

Projeto de Esgotos Sanitários;

Projeto de Drenagem de Águas Pluviais.

Projeto de Aproveitamento de águas pluviais para uso não potável.

2.6. Instalações Mecânicas e de Utilidades:

Projeto de Ar Condicionado;

Projeto de Prevenção e Combate a Incêndio com aprovação junto ao Corpo de Bombeiros do Estado de São Paulo.

Projeto de Instalação de gás.

Projeto de Instalação de gases especiais para os laboratórios.

Projetos de Sistemas de Elevadores

\section{Projetos Legais}

Consistem na representação do conjunto de informações técnicas necessárias à análise e aprovação, pelas autoridades competentes e concessionárias, da concepção da edificação, dos seus elementos e instalações, com base nas exigências legais (municipais, estaduais e federais) e à obtenção do alvará ou das licenças e demais documentos indispensáveis para as atividades da construção.

Deverão ser graficamente representadas as plantas, cortes e fachadas em escala adequadas, com todas as descrições e justificativas de acordo com cada uma das apresentações nas concessionárias de serviços, corpo de bombeiros e demais órgãos do poder público local. O acompanhamento da tramitação e a aprovação dos projetos serão de responsabilidade da contratada.
3.1. Prefeitura de São Bernardo do Campo
3.2. Corpo de Bombeiros
3.3. Eletropaulo
3.4. SABESP
3.5. Petrobrás
3.6. Outros - DERSA, DPRN, CETESB, etc.

\section{Projeto Executivo}

O projeto executivo de arquitetura deve conter todas as informações necessárias para o perfeito entendimento do projeto e execução da obra, que iniciará no inicio de 2009 , com todas as informações, detalhamentos e acabamentos pertinentes a esta etapa de projeto.

Deverá prover também subsídios para montagem do plano de licitação e gestão da construção, compreendendo a sua programação, a estratégia de suprimentos, as normas de fiscalização e outros dados necessários em cada caso;

A orçamentação do custo global da construção fundamentar-se-á em quantitativos de materiais, serviços e fornecimentos apropriadamente avaliados. Os preços dos serviços deverão ser obtidos a partir de planilhas oficiais - SINAPI - ou privados com reconhecida aceitação no mercado;

O conjunto dos projetos executivos será apresentado em arquivos com extensão dwg (AutoCAD), plt (Plotter) e pdf (Adobe Acrobat). Planilhas e textos de extensão.doc (Word) .xls (Excel) gravados preferencialmente em compact disk, não-regravável, e em 02 (duas) cópias impressas nas escalas previstas em normas técnicas. 


\section{MINISTÉRIO DA EDUCAÇÃO \\ FUNDAÇÃO UNIVERSIDADE FEDERAL DO ABC \\ PRÓ-REITORIA DE ADMINISTRAÇÃO \\ COMISSÃO ESPECIAL DE LICITAÇÃO}

Processo $n^{\circ} .23006 .000232 / 2008-79$

O projeto executivo será composto pelos seguintes produtos ( Anexo VII):

Compatibilização do Projeto Básico

Aprovação dos Projetos Legais

Memoriais Descritivos dos projetos;

Relatório técnico e memorial justificativo e de cálculos para cada projeto complementar;

Caderno de encargos contendo as especificações de materiais e serviços;

Planilhas de Quantitativos;

Orçamento detalhado do custo global da obra/ Cronograma da Obra

Desenhos:

4.1. Urbanismo (para toda a extensão da gleba):

Projeto de Implantação

Projeto de Terraplenagem

Projeto de Sistema Viário e Geométrico

Projeto de Paisagismo

Projeto de Infra-estrutura

4.2. Arquitetura

Projetos das edificações - plantas, cortes, fachadas, layout e detalhamento.

Projeto de Comunicação Visual

4.3. Fundações e Estrutura

Projeto de Fundações;

Projeto de Estrutura de Concreto;

Projeto de Estrutura Metálica.

4.4. Elétrica

Projeto de Instalações Elétricas, energia solar e fotovoltaica.

Projeto de Sonorização e TV a Cabo;

Projeto de Circuito fechado de TV;

Projeto de Detecção e Alarme de Incêndio;

Projeto de Rede de Comunicação de Dados e Telefonia (Cabeamento Estruturado);

Projeto de Supervisão, Comando e Controle de Edificações;

Projeto de Proteção contra Descarga Atmosférica;

4.5. Hidráulica

Projeto de Água Fria;

Projeto de Esgotos Sanitários;

Projeto de Drenagem de Águas Pluviais.

Projeto de Aproveitamento de águas pluviais para uso não potável.

4.6. Instalações Mecânicas e de Utilidades:

Projeto de Ar Condicionado;

Projeto de Prevenção e Combate a Incêndio com aprovação junto ao Corpo de Bombeiros do Estado de São Paulo.

Projeto de Instalação de gás.

Projeto de Instalação de gases especiais para os laboratórios.

Projetos de Sistemas de Elevadores 
MINISTÉRIO DA EDUCAÇÃO

FUNDAÇÃO UNIVERSIDADE FEDERAL DO ABC

PRÓ-REITORIA DE ADMINISTRAÇÃO

COMISSÃO ESPECIAL DE LICITAÇÃO

Processo n. 23006.000232/2008-79

ANEXO III

PLANTA CADASTRAL

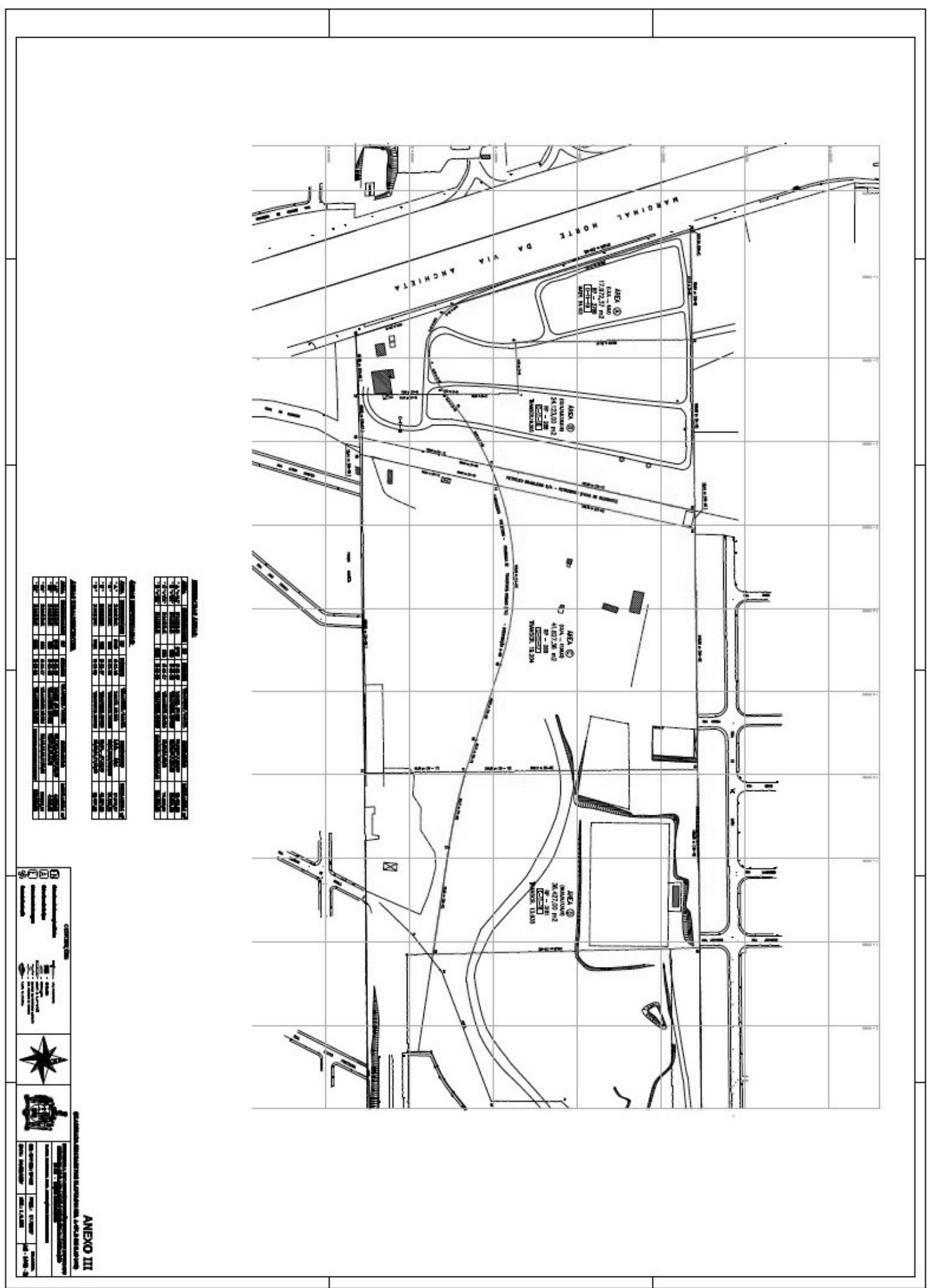


MINISTÉRIO DA EDUCAÇÃO

FUNDAÇÃO UNIVERSIDADE FEDERAL DO ABC

PRÓ-REITORIA DE ADMINISTRAÇÃO

COMISSÃO ESPECIAL DE LICITAÇÃO

Processo n. 23006.000232/2008-79

ANEXO IV

LEVANTAMENTO PLANIALTIMÉTRICO

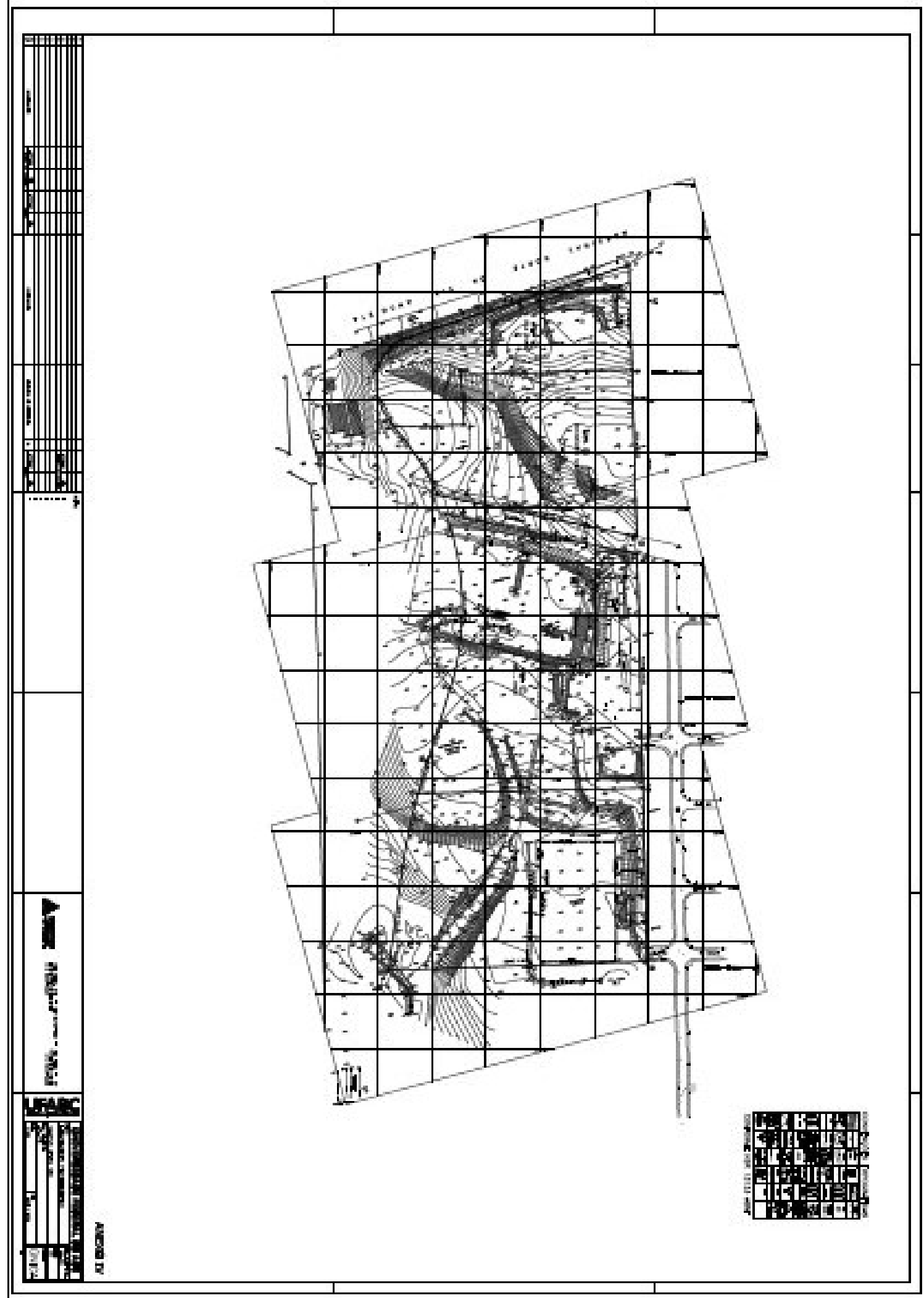




\section{MINISTÉRIO DA EDUCAÇÃO \\ FUNDAÇÃO UNIVERSIDADE FEDERAL DO ABC \\ PRÓ-REITORIA DE ADMINISTRAÇÃO \\ COMISSÃO ESPECIAL DE LICITAÇÃO}

Processo $n^{\circ} .23006 .000232 / 2008-79$

\section{ANEXO V \\ DIRETRIZES URBANÍSTICAS DA PREFEITURA DE SÃO BERNARDO DO CAMPO}

Secretaria de Planejamento e Tecnolojia da Informaçâ

Departamenta se Planejionemo Estrabogico

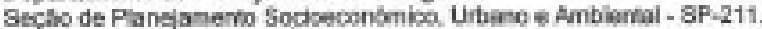

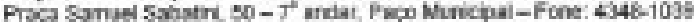

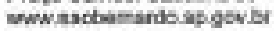

\section{DIRETRIZES}

Processo Administrstivo: SB 02162/2008-57

Proprietario: Repeblica Federativa do Brasil

Interessado: Gowerno Federal

Assunto: DIRETRIZES PARA IMPLANTAÇÃo DO CAMPUS II DA UNIVERSIDADE FEDERAL DO GRANDE ABC - UNIDADE DE SÁO BERNARDO DO CAMPO

Localizapao: Marginal Esquerda da Via Anchieta altura do Km 17

Area: 120.349,73 m²

Inscriçes Imabilíbrias: 011.003.001.000; 011.003.007.000; 011.003.006.000 parte de 011.003.029.000

DIRETRIZES ESPECIFICAS PARA USO E ATIVDADE EXCEPCIONAL - CONFORME LOI Municipal 5.716/2007, Capitulo III, Seção II.

\section{A: Uso e ocupaça do solo}

Os imóweis situam-8e em Macrozona de Vocaçato Urbana - MVU, em Zona de Desenmolvinsento Urbano, cłassificaçă 3, em Unidade de Planejamento e Gestáo Empresarial - UPG-E-05, para efeitos da LM 5.583/2006 - Plano Diretor e em Áree Empreearial Permissiva tipo 2 - AEP2-04, para efertos da Lei de Uso e Ocupaçáo do Salo no municipio - L.M. 5.716 / 2007, assim oomo em Area Urbana de Ocupaçșo Vocacional - AUV. $1 /$ SE 1-4, conforme LM. n. ${ }^{\circ} 4,803 / 99$ e suas alteraçbes;

Em tace ao artigo 28 da LM $5716 / 2007$, a stividade pretendida define-se como excepcional:

Diretrizes especificas conforme artigo 29 parágrafo $2^{0}$ da LM 5716/2007.

Coeficiontes de Utilizaçato e Ocupaçăo a serem adotados para este uso excepcional:

a) Coeficiente de utlizaça máximo igual a 4,0 (quatro);

b) Conficiente de Ocupaçäo maximo de $50 \%$ pera coeficiente de utilizaça 4,0

c) Coeficiente de Ocupaçalo maximo de $80 \%$ para coeficiente de utilizaça 2,5

d) Deve ser observada a equaç5o do artigo 47 da LM 5716/2007 para coeficienies de ccupaça cm referencia aos coeficientes de utilizaçao no intervalo entre 2,5 e 4,0.

\section{Para as edificaçōes:}

Recuos:

a) Recuo minimo de frente para Marginal Esquerda da Via Anchieta, prever $30,00 \mathrm{~m}$ (trinta metros), a partir do limite da faixa de dominio da Rodovia Anchieta para com o iorreno;

b) Recuo minimo de frente para a Av. Sáo Paulo (ramo 400), de 15,00m (quinze metros),

c) Recuo minimo de frente para a Rus " $A$ ", 10,00m (dez metros)

d) Recuo minimo de subsolo, para a Rua " $A$ ", $5,00 \mathrm{~m}$ (cinco metros)

e) Recuos tatersis e de fundos $e$ afastamento entre predios no mesmo imóvel:

1. recuo de 5,00m (cinco metros): att 12 pavimentos ou $36,00 \mathrm{~m}$ (trinta 9 sais metros) de altura: 


\title{
MINISTÉRIO DA EDUCAÇÃO \\ FUNDAÇÃO UNIVERSIDADE FEDERAL DO ABC \\ PRÓ-REITORIA DE ADMINISTRAÇÃO \\ COMISSÃO ESPECIAL DE LICITAÇÃO
}

Processo $n^{\circ}$. 23006.000232/2008-79

\author{
Secretaria de Planejamento e Tecnologia da Informaçâso \\ Departamerte de Plansjamento Estrategico \\ Seça de Plsnejamerto Socioecanómico, Untano e Ambiental - SP.211. \\ Praca Samuel Sabatini $50-T$ anda: Paco Murbited - Fene. 4348-103e \\ whe sabemarto sp gavibt
}

2- recuo de $7,00 \mathrm{~m}$ (sete metros); de 13 pavimentos ou $38,01 \mathrm{~m}$ (trinta e seis metrce e um centimetro), ate 30 pavimentos ou $88,20 \mathrm{~m}$ (oitenta e oito metros e vinte centimetros) de altura, e

3 - recus de 10,00 m (dez metros): mais de 30 pavimentos ou 88,21m (oitenta e oto metros e vinte e um contimetros) de altura.

Das areas nđ̂o computadas para coeficiente de utilizaçăo:

Náo serảo computadas para efeito do callculo do coeficiente de utilzaçło e para cálculo da altura, mesmo que conjugadas a cutras categorias de uso, as areas destinadas a:

a) praças internas e exdernas, teatros, salas de espetáculo, cinemas e anfiteatros (excluidas salas de aula ou anfiteatros utilizadoe como taly?

b) pavimentos destinados à fruiçăo pública como eirculação de pedestres, localcadas no pavimento térreo ou em pevimentos correspondentes à saleira de ingresso da edficaçắo no nivel dos logradource púdicos:

c) estacionamento de veiculce ate o limite máximo igual a 2 (dois) pavimentos acima do nivel da soleira, devendo respeitar recuo de frente de $30 \mathrm{~m}$ para a Marginal Esquerda da Via Anchieta e de $15,00 \mathrm{~m}$ (quinze metros) de frente para a Via do Túnel;

d) poróes esubsolos sem aproveitamento para qualquer atividade permanente ou habitaçalo;

e) casa de máquinas, caixas dagua e reservatónios;

f) areas de gtividades sociais e recreativas, tais como churragqueiras, saides de fests e outras;

g) habitaçక్s de zelador, quando a área construida năo superar $50,00 \mathrm{~m}^{2}$ (cinqüenta metros quadrados);

h) cabines-de-forç, guaritas e portaries;

i) circulaçăo horizontal e vertical de uso comum dos edificios do campus, $e$

i) helponto.

\section{B: Vias de circulaçlo e acesso}

Informacto:

A SMT-1 manifesta-se que năo há como ela no momento, dar um parecer tb́cnico, quanto às vias de circulaça e acessos sem que a mesma seja previamente informada se há a aprovaçāo junto ao Dersa quanto ao acesso pela Marginal da Va Anchieta assim como é necessarla a apresentaçio da planta de locallzaçelo do empreendimento com a Indicaçäo das possiveis vias de acesso., desta forms, as diretrizes quanto às vias de circulaçăo e acessos, se dará previamente ao alvara de construç̧o, durante o processo de aprovação deste.

Para elaboraçáo do projeto, considerando o que precanizado no Código de Transito Brasileiro, e na L.M. 5.716/07, o interessado deverá:

1- Prever e grafer em planta no minimo 01 vaga para cada 02 estudantes;

2. Prever e grafar em plenta o total de vagas para pesscess de mobilidade reduzida, de acordo com o Decreto Federal $n^{4} 5.296 / 2004$ que prevê $2 \%$ das vagas a serem destinadas para pessoas de mobiildade reduzida;

3- Prever e grafar em planta vagas em separado das chadas acima, para equipementos como cinema, selas de espetáculos, featro e anfitestro:

4- Prever acesso com faixa de acelerapao e desaceleraçă: acesso em que a ligaçăo entre a via púbilca e a ârea de estacionamento dispōe de trecho paralelo à via pública que permilte a reduçăo de velocidade para acessar ou sair do estacionamento; 


\title{
(1) \\ MINISTÉRIO DA EDUCAÇÃO \\ FUNDAÇÃO UNIVERSIDADE FEDERAL DO ABC \\ PRÓ-REITORIA DE ADMINISTRAÇÃO \\ COMISSÃO ESPECIAL DE LICITAÇÃO
}

Processo $n^{\circ} .23006 .000232 / 2008-79$

\author{
Socrotaria de Planejamento a Tecnologia da Informaça

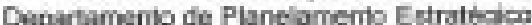

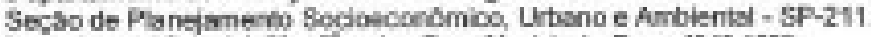

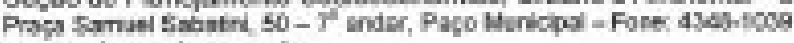

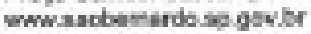

5- Prever acesag com hrea de acumulaça: acess em que, alem da taixa de decaceleracto, hala area de parada suficiente para coniter parte da demanda ao astacionamerilo antes do dspositho de controle do apesso (ex. pottaria) ou, no caso da ineristencis desta, antes do acasso te primeira vaga;

6- Prover grafir em planta local para emberque e dasembarque de penugs. micro bnibus a onlbus escolares:

7- Sinalzacho vertcal Griemitentej, nas entradas e saidas de automóneis e utilitarios;

8- Prever e gralar em planta o acesso e local de carga e descarga; e

9. Prener acesses desvinculados de pedegtres e velculos.

Atendor criburios estabelocidos pela Secrebrie do Estado dos Negocios de Segurance Pública - Policla Militar do Eatado do Sto Paulo - Copo de Bombeiros e aliemates posteriores - para caso haja uso residencial dentro do campus;

C: roserva do área lnstítucional e outros equipamentos públicos:

Considerendo tratar-se de atividade eroepcional, para melhor interface e conleatualizaçán desta para com seu entomo:

1- a Universidade devera prever na frente para a Av. Bao Paslo, o na diviag com a ára do futuro Campus da Faculdade de Dirello Sao Eemardo, dress verdes lirres (pracsis). para convivo e interface entre a universidade e o entorno

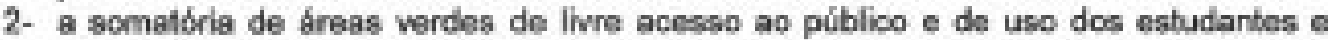
funcionarios da universidade, devera ser de no minimo $10 \%$ da area do terreno

3- a Universidade deverd prever bolsso varde de no minimo 5 meiros na divisa com os fundas residenciais do loleamento Jd. Hollywood, para minimizar impactos sonoros e outros para com a vizinhanca imodiata

4- a Universidade devera prever passarela de interlgacto o transposipao da via Anchiela, de forma a possibilitar o acesso de pedastres talunos, docenles, funciontrios e autrosj, sendo necesstria a prbvis oitiva da DERSA quanto a implantagho deata dirctriz.

5- a Univorsidade demorá prever paradas de Cnibus nas Margnais Direita e Eequerda da Me Anchiela, na altura da passerela dupra cilada, de modo a proporcionar diminuicaso de lifjeto de trensporte coletio a Universidade e faciltar a asesso de pedesires a mesma, sendo necosstiria a priva oitiva de DCRSA quanto i implantaçio desta diretriz.

E: Agua, osgoto e aguas pluvials:

1- Praver sialemas de reuso de tajus.

2- Prever sisternas de tanques de retenctan de aquas plovisis etou sistemas do percolacho destes, conforme depocto no Lei Extedual 124262607 .

3- Prever sistemas de aquecimento sclar de dgua, para atendmento a vestiarios de funcionhílos fe de flunos. bem como possivel uso para ee for o caso, em piscinas

4- Solictar junio a SABEBP - Companhia de Sanaanento Basioo do Estado de SAco Paulo as diretrizes de taua a eggoto.

Para efelo dos cáloulos hidrabloos a hidrologlos, os coletores deverdo comportar a seguinte vacao Periodos de Retorno -25 anos para emproendimentas o 50 anos para ramanejamento de tubulapóes püblicas, oom escoamanio míximo a $2 / 3$ de $8 e c$ ío velocidade náo euperior a $5 \mathrm{~m} / \mathrm{s}$. Devera ser apresentado o calculo completo dofs escoamento(s) final(ts) da galerla, ou aeg, pelo menos do ollino PV - Poco de Visita antes das galprias publicas ou corregos, junto com o memorisl describio e memála da calculd. 


\title{
$0^{*}$ \\ MINISTÉRIO DA EDUCAÇÃO \\ FUNDAÇÃO UNIVERSIDADE FEDERAL DO ABC \\ PRÓ-REITORIA DE ADMINISTRAÇÃO \\ COMISSÃO ESPECIAL DE LICITAÇÃO
}

Processo $n^{\circ} .23006 .000232 / 2008-79$

\author{
Secrataria de Planejamento e Tecnologia da Intormaçato

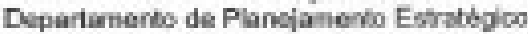

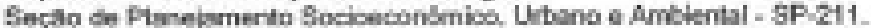

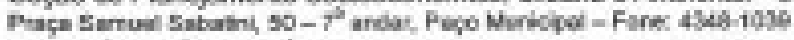 \\ whisubtmatuspop b
}

F: Em caso de existencia de vegetacto

A SHAMA tomou como refertencia, para firs de andise teonica, a aroa delimitada pela poligono existente entre a Marginal Norte da Va Anchleta ate aproimadamente o alinhamento da Rua Arctunus, entre o Parque Anchieta e a Vila Tereza, confome roqu anew.

A andise do Bistama Cartografico Matropoltano indoou a prosenca de curso d'agua na porçåo sudede do imónel, o que caracteriza Area de Presanaço Pemanente-APP, assim definida pela Rosolucto CONAMA 30202. Sugerimos, pana tarilo, que o interessado consulte a pror o Depertamento Estadual de Protocto dn Recursces Naturais - DEPRN antecedendo qualquer interteranda naseas areas protogidas por loi contormo Cbdigo Flonesial (Lei ${ }^{\circ}$. $477165)$.

Informamos, ainda, qun apde vistoria realizade no ülimo dia 28 de janeiro do corrente,

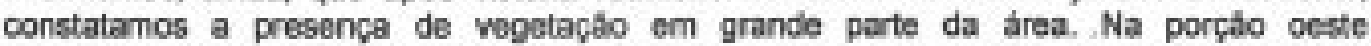
identicamos um mactes florestal compasto por vepatepho socundaria em estigio iricial de

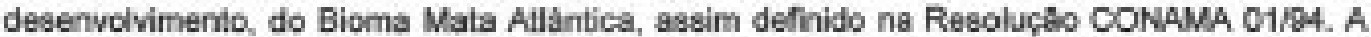

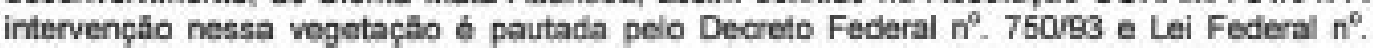
11.424tos, sendo compotonola do drgao estadual, nesto caso o Departamento Estadual de Protefầ de Recursos Naturais - DEPRN, a autoritacho para o corte, supressoo ou explorepto da meame:

O restante da área de composto por regetaçlo eecundária em estagio pioneiro, com presença de exemplares arbóreos isolados, natwos e exbtions, Em caso de necossidade de poda, corte

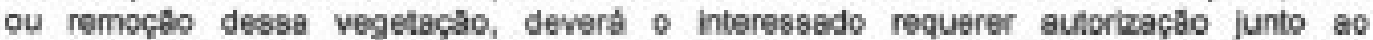
Departamento de Lioanciamento e Avaliacso Ambiental (SHAMA-3), por melo de processo administratima próprio. Para tanto davert apresentar:

1. Documenis quo comprowe a tifulardade da drea:

2. Protocolo de abertura de processo de Alvera de Construcso;

3- Prolato de inplantagaso do empreendimenlo grafado com a localizagáo dos etemplartes arboteos a serem removidos to

4- Proposta de compensaçio ambiental a ser realizada por meio do plantio de mudas de ärvores do especies natives da Mata Atiantica, no podprio imóvel, atendendo ao daposto ne Regolucto SMA 18 iot a Lei Municipel in'. $4861 / 98$.

G: Outros.

Antecedendo aprovacto do empreendimento deverá ser providenciado:

1. obpia do instumarto qun habilita o reitor da Unwersidede a represente-la e oe respectwoe poderos:

2- certibes das malriculas doe indveis abualizadas;

3- a projeto dever contomplar as aroas como un todo, como se fi tshessem memembradas, devendo tal remembramento ear pleifeado e levado a registro táctogo soja lavrads a tocrilura de venda e compra referida na Cláusula Sexth do Instrumento de Compromiseo de Venda e Compra; 


\section{MINISTÉRIO DA EDUCAÇÃO \\ FUNDAÇÃO UNIVERSIDADE FEDERAL DO ABC \\ PRÓ-REITORIA DE ADMINISTRAÇÃO \\ COMISSÃO ESPECIAL DE LICITAÇÃO}

Processo n ${ }^{\circ}$. 23006.000232/2008-79

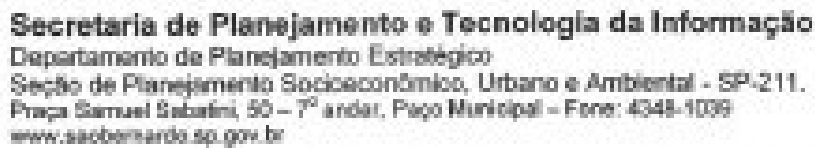

4- ART dos responsáveis técnicos pelos projetos apresentados, bem como cópias das respectivas identificaçbes profissionais emitidas por esta Prefeitura;

5- Certidlo negativa de tributos imobilírios muricipais ou vinculados à propriedade imobliária, expedida ate 30 (trinta) dias anteriores a data de formalizaçào do pedido de

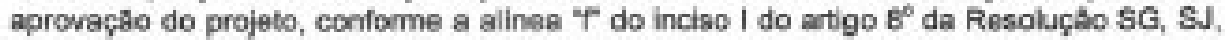
SO, SP, SHAMA e SMT $n^{*}$ 004, de 2007, caso subsista alguma responsabilidade tributaria ds UFABC.

6- Deve ser previsto sistemas de proteçầ acusticce nos equipamentos de cinemas, teatros e anfiteatros; 6

7- Atividades complementares da universidade a semelhança de papelarias, xerox, fivrarias, lanchonetes e semelhantes, njo poderấo ter acesso direlo por via pública ou terem acesso direto a prapa ou espapo fivre que faça divisa com via pública, davendo estes localzarem-se no interior da universidade para atendimento exclusivo de alunos, docentes e funcionánios da mesma.

Após aprovaçẩo do emproendimento, deverá ser fomecida, para acervo digital do Departamento de Vias Públicas e do Cadastro Municipal 01 (uma) copia em papel e 01 (uma) cobia em arquivo digtal (desenhos $e$ detalhes em dwg $e$ memoriais em "doc.") completa dos projetces de:

- Drenagem (desenhos grfficos, memoriais e detalhes);

- Vário (desenhos graficos, memoriais e detalhes); $\theta$

- Projeto arquitotónico o urbanistioo (cobia apenas em midia digital - CD-Rom - do desenhos graficos e memoriais).

\section{H: Prazos}

O prazo de validade do documento será no máximo 05 (cínco) ance.

\section{DIRETRIZES GERAIS}

I: Devera ser apresentado e aprovado Estudo de Impacto de Vizinhança, conforme artigo 13 da LM 5714/2007 e artigo 29 da LM 5716/2007.

J: No que couber, deveraso ser atendidas, além de outras:

Leis Municipais:

-LM 1950/1971 - Alterada pela LM 4.158493 - adota o Codigo de Obras "arthur Saboya";

LM 1.052/1952 - Instalaço de rede de telelonia;

LLM 1,691/1968 - Para-raios;

-LM 2.408/1980 - Terraplenagem (movimento de terra);

LM 3.033/1988 - Instalaç̧̃o de Lixeiras:

LM 4.373/1995 - Adota Decreto estadual sobre proteḉ́o contra incelndios: 


\section{MINISTÉRIO DA EDUCAÇÃO \\ FUNDAÇÃO UNIVERSIDADE FEDERAL DO ABC \\ PRÓ-REITORIA DE ADMINISTRAÇÃO \\ COMISSÃO ESPECIAL DE LICITAÇÃO}

Processo n'. 23006.000232/2008-79

\section{Becrotarla do Planojamonto e Tecnolopia da Informaça

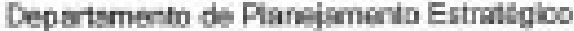

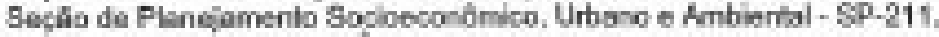

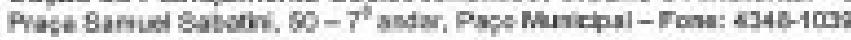 \\ Hus ontermath ap ent}

-LM 4 Aryigse - Parcelemento do solo urtana;

-LM 4, 764/1969 - Gaha de comespondencia.

-LM 4.661/1959 - Disciplina corte de árvores em áress particulares do municipio;

-LM 4.974/2001 - Codigo de Posiuras: E

-LM 5.716r2007 - Lei de Uso e ocupocáo do solo no Municjplo.

Lei Estadual

- LE. $\pi^{\circ} .12526 / 2007$ - Tanques de Retencto de ápuas pluvias

Decreto Estadual

$-\pi{ }^{\circ} 12342 / 1978$ (Codgo Bantário)

Lei Federal

- LF 10,0902000 - Loi de Aressibilidade

- Decrelo Federal - 5.2962004

- NER 9050/2004

\section{J: ANEXOS:}

- Planias devidamente chanceladas a rubricadas pelo Departamento de Planejamento

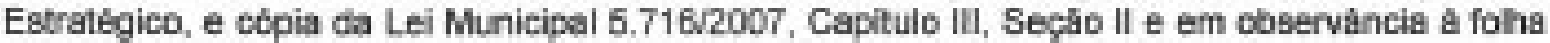

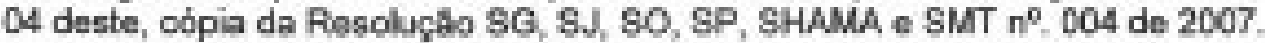

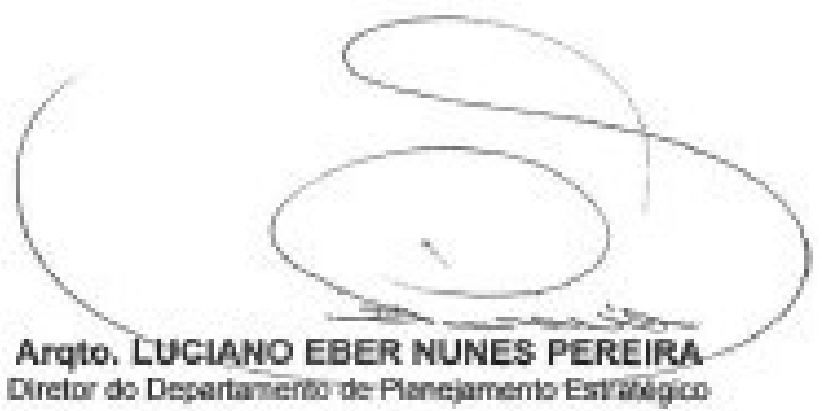

